UNIVERSIDADE DE SÃO PAULO

FACULDADE DE ECONOMIA, ADMINISTRAÇÃO E CONTABILIDADE DEPARTAMENTO DE ADMINISTRAÇÃO

PROGRAMA DE PÓS GRADUAÇÃO EM ADMINISTRAÇÃo

\begin{abstract}
LIDERANÇA E SUAS RELAÇÕES COM A ESTRATÉGIA DE GESTÃO DE PESSOAS E O BEM-ESTAR ORGANIZACIONAL: UM ESTUDO COMPARATIVO EM DUAS INSTITUIÇÕES FINANCEIRAS INTERNACIONAIS
\end{abstract}

Silvio Roberto Stefano

Orientadora: Prof ${ }^{\mathrm{a}}$. Dr ${ }^{\mathrm{a}}$. Ana Cristina Limongi-França

SÃO PAULO

2008 


\section{$\operatorname{Prof}^{\mathrm{a}}$. Dr ${ }^{\mathrm{a}}$. Suely Vilela \\ Reitora da Universidade de São Paulo}

Prof. Dr. Carlos Roberto Azzoni

Diretor da Faculdade de Economia, Administração e Contabilidade

Prof. Dr. Isak Kruglianskas

Chefe do Departamento de Administração

Prof. Dr. Lindolfo Galvão de Albuquerque

Coordenador do Programa de Pós-Graduação em Administração 


\title{
LIDERANÇA E SUAS RELAÇÕES COM A ESTRATÉGIA DE GESTÃO DE PESSOAS E O BEM-ESTAR ORGANIZACIONAL: UM ESTUDO COMPARATIVO EM DUAS INSTITUIÇÕES FINANCEIRAS INTERNACIONAIS
}

\author{
Tese apresentada ao Departamento de \\ Administração da Faculdade de Economia, \\ Administração e Contabilidade da \\ Universidade de São Paulo como um dos \\ requisitos para a obtenção do título de Doutor \\ em Administração.
}

Orientadora: Prof ${ }^{\mathrm{a}}$. Dra. Ana Cristina Limongi-França

\section{SÃo PAULO}




\section{FICHA CATALOGRÁFICA}

Elaborada pela Seção de Processamento Técnico do SBD/FEA/USP

\section{Stefano, Silvio Roberto}

Liderança e suas relações com a estratégia de gestão de pessoas e o bem-estar organizacional: um estudo comparativo em duas instituições financeiras internacionais / Silvio Roberto Stefano. - São Paulo, 2008. $176 \mathrm{p}$.

Tese (Doutorado) - Universidade de São Paulo, 2008

Bibliografia

1.. Liderança 2. Qualidade de vida no trabalho 3. Comportamento organizacional 4. Administração de recursos humanos I. Universidade de São Paulo. Faculdade de Economia, Administração e Contabilidade. II. Título.

$$
\text { CDD - } 658.4092
$$


A minha esposa Luciane, pelo amor e compreensão que foram fundamentais para a realização deste doutorado. 


\section{AGRADECIMENTOS}

Agradecer é um momento fundamental quando da realização de um trabalho extenso e complexo como uma tese de doutorado, pois durante a realização deste várias pessoas contribuíram direta ou indiretamente para a realização deste.

A minha orientadora, Professora Dra. Ana Cristina Limongi-França, foi uma pessoa fundamental por seus ensinamentos, sugestões, críticas, conselhos e principalmente paciência no decorrer do doutorado, apontando caminhos para que fosse possível a concretização deste trabalho. Agradeço não só sua atenção e orientação, mas principalmente sua sabedoria no decorrer do nosso percurso do doutorado.

Aos professores Dr. Arnaldo José França Mazzei Nogueira, Dr. Lindolfo Galvão de Albuquerque, Dr. André Luiz Fischer, Dr. Silvio Aparecido Santos, Dr. Joel Souza Dutra, Dra. Maria Tereza Leme Fleury, Dra. Tânia Fischer, Dr. Antonio Carlos Aidar Sauaia, do programa de pós-graduação em Administração da Faculdade de Economia, Administração e Contabilidade da Universidade de São Paulo, que ministraram ensinamentos importantes para o nosso aprofundamento nos estudos em gestão de pessoas, comportamento organizacional, gestão das organizações e para a realização deste estudo.

Aos professores Dr. Moacir de Miranda Oliveira Junior e Dr. Antonio Cesar Amaru Maximiano, membros da banca de qualificação, cujas correções e sugestões foram importantes para a realização deste trabalho final.

Aos professores da banca de defesa final, Dr. João Luiz Passador, Dr. Álvaro de Oliveira Borges Filho, Moacir de Miranda Oliveira Junior, Dr. Joel Dutra e nossa professora orientadora.

Aos grandes colegas e amigos de turmas de doutorado, que com os debates, ensinamentos, trocas de experiências, auxílio foi possível concluir as disciplinas e a realização deste trabalho. Obrigado Alba Estela Sánchez Souza, Alessandra Quishida, Alex Antonio Ferraresi, Ana Carla Scalabrin, Annelise Vendramini, Antônio de Pádua Araujo, Carlos Augusto da Silva Loures, Clément Alain Jean-claud Huret, Constantino Rodrigues Cavalheiro, Cyndia Laura Bressan, Edson Cezar Aguiar, Eduardo Caruso Martins, Eduardo Penterich, Eduardo Pereira, Eduardo Pinheiro de Souza, Eliane Maria Pires Giavina Bianchi, Elza Fátima Rosa Veloso, Emerson Antonio Maccari, Fabiano Fiorin, Felipe Mendes Borini, Fernando César Lenzi, Flávia Helena D. Alves Bravin, Francisco de Assis S. Martins, Georgia Tiepolo Schmidt Rogel, Henrique Maia Veloso, Hermann Hrdlicka, Irandy Marcos da Cruz, Italo Fernando Minello, Ivan de Souza Dutra, Jean-Baphist D. Bernard Fiscel, João 
Paulo Paes de Barros Boyadjian, Karine Vernerey, Letícia Fantinato Menegon, Liliana Vasconcellos Jacobsohn, Luciano Augusto Toledo, Luciano Venelli Costa, Luiz Felipe Quel, Marcelo D’Emidio, Marcos Abilio Bosquetti, Marcos Aurélio de Araújo Ferreira, Marcos Praxedes da Silva, Maria Cecília Cavalcante da Silva, Maria Cristina Pinto Gattai, Maria Izabel Costa, Mariana Pereira das Neves, Melissa Franchini Cavalcanti Bandos, Nildes Pitombo Leite, Olga Miranda, Patrícia Morilha de Oliveira, Patrícia Portella Prado Galhano, Pierre-Edouard Paquet, Renata Schirrmeister, Roberto Kenicke Junior, Rosalina Semedo de Andrade Tavares, Sérgio Nunes Muritiba, Simon Sebastian Jâhnichen, Solemar Merino Jorge, Talita Gil Regis do Amaral, Ulrico Barini, Valéria Riscarolli, Victor Richate Martinez, Viviane Rossini e Volnei Gonçalves Pedroso, entre outros.

Minha gratidão aos professores do Departamento de Administração da Universidade Estadual do Centro-Oeste do Paraná pelo apoio e incentivo para a realização deste trabalho.

Aos amigos de sempre Ivan de Souza Dutra, Márcia Aparecida Zampier e Sandra Mara de Andrade que foram fundamentais para as discussões do trabalho.

Aos bancários que participaram da pesquisa de campo, anônimos, sempre cordiais, cedendo seu tempo e informações que foram fundamentais para a concretização deste trabalho final.

Ao Estatístico João Vinicius França Carvalho, pela sua fundamental colaboração na tabulação dos dados da pesquisa de campo, auxiliando para a consecução deste trabalho.

À Universidade de São Paulo, na figura de seus funcionários que sempre estiveram a disposição, fornecendo informações e auxiliando no suporte para a realização deste trabalho.

Aos meus pais que sempre me incentivaram e apoiaram para o estudo e aprimoramento pessoal e profissional.

A Deus por me dar condições para a realização deste trabalho. 


\section{RESUMO}

A globalização das economias trouxe reflexos no sistema financeiro e no setor bancário, onde as recentes alterações no cenário econômico, juntamente com a alta concentração das instituições financeiras, demonstram a dinâmica do setor. A competitividade entre os bancos deve se acentuar no tempo como forma de conquista de maiores espaços. Nesta perspectiva, a gestão de pessoas deverá exercer um papel cada vez mais importante na oferta de novos serviços e na gestão mais efetiva de suas estruturas e de seu quadro de pessoal, cada vez mais qualificado e responsável pelos resultados dessas instituições. Nesse contexto, a gestão estratégica de pessoas ganha destaque como formuladora, implementadora e avaliadora de resultados para o alcance de vantagens competitivas, baseadas na gestão de pessoas alinhada com as estratégias organizacionais. Os líderes poderão conduzir grupos de subordinados para determinados resultados. Para isso é relevante a satisfação dos colaboradores com os fatores biológicos, psicológicos, sociais e organizacionais da qualidade de vida no trabalho. Este estudo teve como objetivo principal analisar o grau de importância da liderança orientada para resultados, na percepção dos profissionais da área de gestão de pessoas de duas Instituições Financeiras Internacionais que atuam no Brasil, e suas relações com a gestão estratégica de pessoas e com os níveis de satisfação dos aspectos organizacionais, biológicos, psicológicos e sociais. O método envolveu uma pesquisa exploratória, ocasional única, com uma amostra de cento e cinqüenta e oito respondentes, realizada nos meses de julho, agosto e outubro de 2008. Os principais resultados foram: a caracterização das instituições financeiras; identificação nas duas organizações políticas estruturadas de gestão de pessoas com relação ao recrutamento e seleção de pessoal, treinamento e desenvolvimento, cargos e salários, benefícios sociais, avaliação de desempenho e a higiene e segurança no trabalho. As características demográficas dos respondentes da pesquisa de campo por instituição financeira foram: a maioria dos participantes da área de gestão de pessoas dessas instituições era composta de técnicos, analistas ou auxiliares, na maioria mulheres e jovens até 35 anos, que possuíam superior completo ou eram pós-graduados e que não tinham dependentes. O banco Alfa é mais orientado para a liderança de resultados do que o banco Beta e os líderes são mais motivados com a obtenção de resultados positivos. As correlações apontaram que a determinação do que o funcionário deve fazer para melhorar os resultados finais tem uma correlação positiva com a comunicação interna das metas e objetivos. O envolvimento em atividades e oportunidades de desenvolvimento que ajudam a produzir melhores resultados tem uma correlação com a comunicação interna das metas e objetivos. $\mathrm{O}$ envolvimento em atividades e oportunidades de desenvolvimento que ajudam a produzir melhores resultados tem uma correlação com a determinação do que o funcionário deve fazer para melhorar os resultados finais. A satisfação em relação às oportunidades de carreira tem uma correlação com variáveis de gestão estratégica de pessoas, aspectos organizacionais e psicológicos. Os aspectos psicológicos apresentam uma correlação entre a satisfação com as oportunidades de carreira e participação. Rejeitou-se todas as hipóteses de pesquisa, ou seja, representando que existe associação entre os fatores de estudo, mostrando que os comportamentos perceptivos são diferentes, de acordo com os respondentes da pesquisa. As principais contribuições do estudo são do entendimento do tema ora estudado e para identificação da dinâmica da gestão de pessoas nas instituições pesquisadas. Para a comunidade científica foi importante o estudo, pois verificou-se como esses constructos se relacionam e podem contribuir para os resultados das organizações e para a qualidade de vida no trabalho dos seus colaboradores. Este trabalho é relevante, pois os dados da pesquisa demonstraram que quanto maior o investimento em políticas de gestão estratégica de pessoas com visão transformada, maior será a satisfação com os aspectos da qualidade de vida no trabalho.

Palavras-chave: Liderança orientada para resultados, gestão estratégica de pessoas, qualidade de vida no trabalho, bem-estar organizacional, comportamento organizacional. 


\begin{abstract}
The globalization of the economies has resulted in some modifications on the financial and banking systems, where the recent changes in the economical scenario, allied with a high concentration of financial institutions, has demonstrated the dynamic of this sector. The competition among banks will increase in the following years, once they will be trying to reach larger market shares. From this perspective of view, the management personal has an important mission by offering new services and adding value on their structures and staff, which has to be more qualified and responsible on the company results. This way, the strategic management has an important task of formulating, implementing and evaluating the results in order to obtain competitive advantages, based on personnel management which has to be aligned with the organizational strategies. The leaders will be able to guide its employees in order to achieve the company objectives. Therefore, it is not only necessary to verify the employee's satisfaction but also the biological, psychological, social and organizational aspects of their life quality at work. The main objective of this paper was to analyze the importance of the leadership focused on results, from the perspective of professionals working in two International Financial Institutions located in Brazil, and their relationship with the strategic personnel management and their levels of satisfaction taking in account the biological, psychological, social and organizational aspects. The method has involved an exploratory research, unique and occasional, with a statistic sample of a hundred and fifty eight participants - it was applied from July through October, 2008. The main results were the characterization of the financial institutions; identification of the structured personnel management polices related to the employees hiring process, training and development, positions and earnings, social benefits, performance evaluation, and levels of hygiene and security at work on the studied organizations. The demographic characteristics of the respondents per financial institution are the following: the majority of the participants were composed by technicians, analysts or assistants, and they were most women aging up to 35 years old, graduated or high graduated and having no kids. Alfa bank is most oriented toward leadership results than Beta bank, but the leaders of bank Beta are more motivated toward positive results. The correlations showed that the determination of what the employees should make to improve the company final results is linked to the goals and objectives determined by the company internal communication. The involvement in activities and development opportunities that helps results improvements is linked to the employee's determination of what he or she should make to improve the final results. The satisfaction related to the carrier opportunities is not only linked to personnel strategic management variables, but also to the organizational and psychological aspects. The entire research hypothesis was rejected due to many aspects of the research were associated and the respondents perception were different. The major contributions of this study were the understanding of the theme and the identification of the personnel management dynamic on the financial institutions. The importance of this study to the academic community is related with the aspects that contribute for the organizations toward reaching better results, and also for the life quality at work for its employees. The importance of this study is related to the data collected on the field research which proves that the higher investments in strategic personnel management policies will result on higher employee's satisfaction with the life quality at work.
\end{abstract}

Key-words: Leadership oriented toward results, strategic personnel management, life quality at work, organizational well-being, organizational behavior. 


\section{RESUMEN}

La globalización de las economías trajeron reflejos en el sistema financiero y en el sector bancario, donde los actuales cambios en el escenario económico, juntamente con la alta concentración de las instituciones financieras, demuestran la dinámica del sector. La competitividad entre los bancos debe se acentuar en el tiempo como forma de conquista de mayores espacios. En esta perspectiva, la gestión de las personas deberá ejercer un papel cada vez más importante en la oferta de nuevos servicios y en la gestión más efectiva de sus estructuras y de su cuadro de personal, cada vez más cualificado y responsable por los resultados de las instituciones. En ese contexto, la gestión estratégica de las personas gana destaque como reductora, implementadora y evaluadora de los resultados para lograr ventajas competitivas, basadas en la gestión de las personas junto con las estrategias organizacionales. Los líderes podrán conducir grupos de subordinados para determinados resultados. Para eso es relevante a la satisfacción de los colaboradores con los factores biológicos, psicológicos, sociales y organizacionales da cualidad de vida en el trabajo. Este estudio tuvo como objetivo principal analizar el grado de importancia da liderato orientada para resultados, en la percepción de los profesionales del área de gestión de personas de dos Instituciones Financieras Internacionales que actúan en el Brasil, y sus relaciones con la gestión estratégica de personas y con los niveles de satisfacción de los aspectos organizacionales, biológicos, psicológicos y sociales. El método envolvió una pesquisa exploratoria, ocasional única, con una muestra de cento cincuenta y ocho contestadores hecha en los meses de julio, agosto y octubre de 2008. Los principales resultados fueran: la caracterización de las instituciones financieras; identificación en las dos organizaciones políticas estructuradas de gestión de personas con relación al reclutamiento y selección de personal, treinamiento y desarrollo, cargos y sueldos, beneficios sociales, evaluación de desempeño y la higiene y seguridad en el trabajo. Las características demográficas de los contestadores de la pesquisa de campo por institución financiera fueran: a mayoría dos participantes del área de gestión de personas de las instituciones era compuesta por técnicos, analistas o ayudantes, en la mayoría mujeres y jóvenes hasta 35 años, que hicieron superior completo o posgrados y que no tenían dependientes. El banco Alfa es más orientado para la liderato de los resultados do que o banco Beta y los líderes son más motivados con la obtención de los resultados positivos. Las correlación apuntaran que la determinación de lo que el funcionario debe hacer para mejorar os resultados finales tiene una correlación con la comunicación interna de las metas y objetivos. O envolvimiento en actividades y oportunidades de desarrollo que ayudan a producir mejores resultados tiene una correlación con la comunicación interna de las metas y objetivos. O envolvimiento en actividades e oportunidades de desarrollo que ayudan a producir mejores resultados tiene una correlación con la determinación de lo que el funcionario debe hacer para mejorar los resultados finales. La satisfacción en relación a las oportunidades de carrera tiene una correlación con variables de gestión estratégica de personas, aspectos organizacionales y psicológicos. Los aspectos psicológicos presentan una correlación entre la satisfacción con las oportunidades de carrera y participación. Dejose todas as hipótesis de pesquisa, o sea, representando que existe asociación entre los factores del estudio, mostrando que os comportamientos perceptivos son diferentes, de acuerdo con los contestadores da pesquisa. Las principales contribuciones del estudio son de comprensión del tema ora estudiado y para identificación de la dinámica de la gestión de personas en las instituciones pesquisadas. Para la comunidad científica fue importante el estudio, pues verificose cómo esas construcciones se relacionan y pueden contribuir para los resultados de las organizaciones y para la cualidad de vida en el trabajo de sus colaboradores. Es relevante este trabajo, pues los dados da pesquisa demuestraran que cuanto mayor el investimiento en políticas de gestión estratégica de personas con eso transformada, mayor será la satisfacción con los aspectos da cualidad de vida no trabajo. 
Palabras llave: Liderato orientada para resultados, gestión estratégica de personas, cualidad de vida en el trabajo, bienestar organizacional, comportamiento organizacional. 


\section{SUMÁRIO}

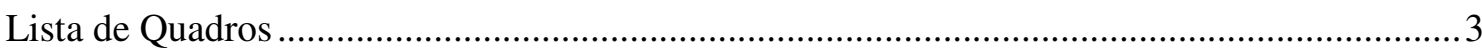

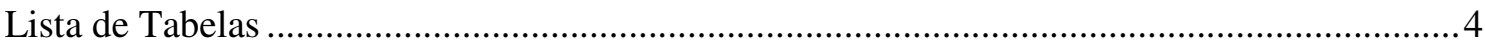

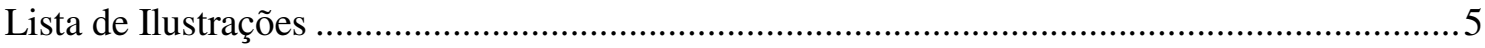

CAPÍTULO 1- INTRODUÇÃ

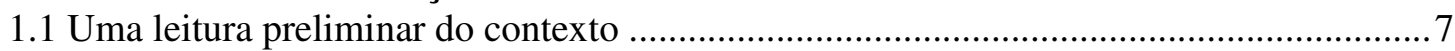

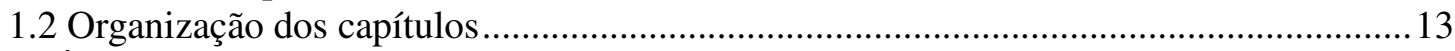

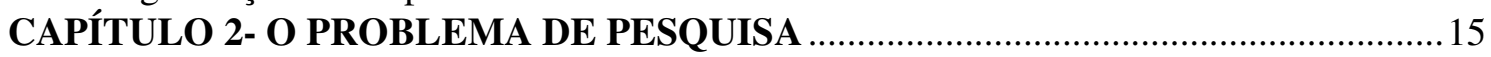

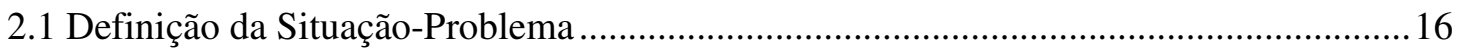

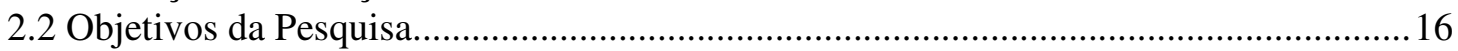

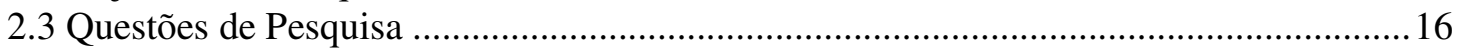

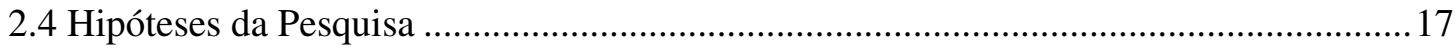

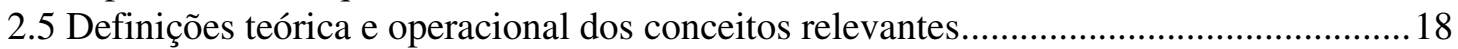

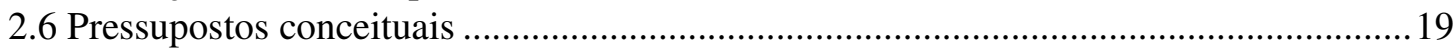

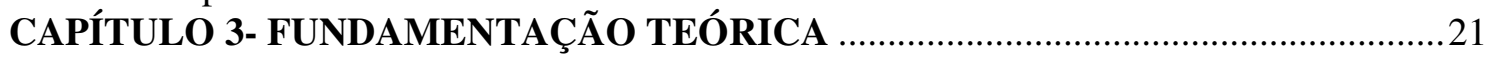

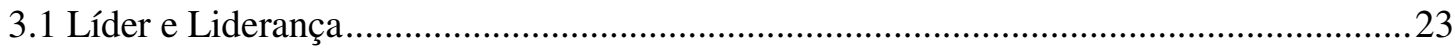

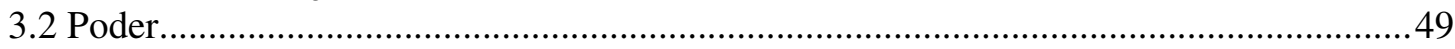

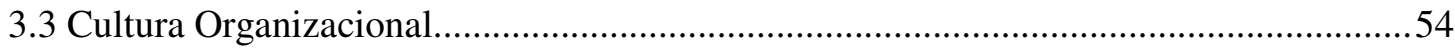

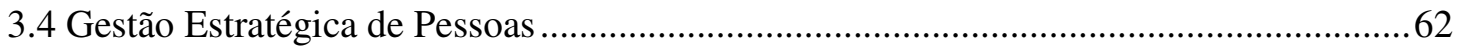

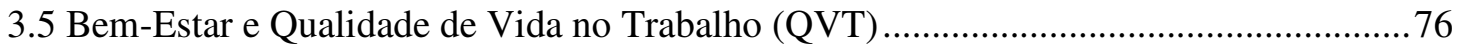

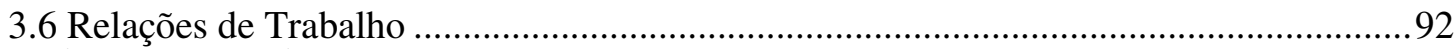

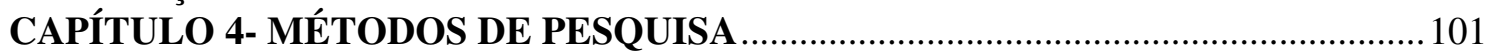

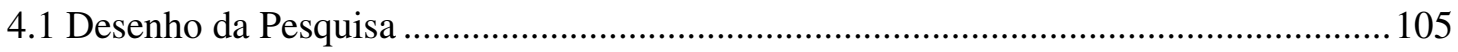

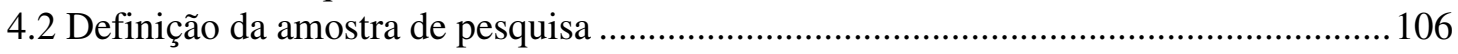

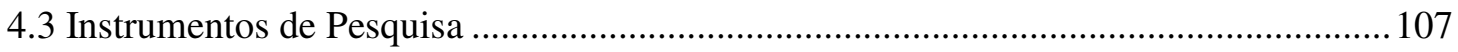

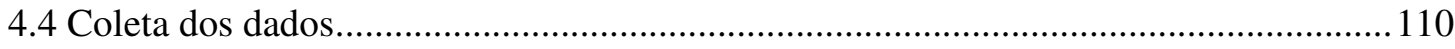

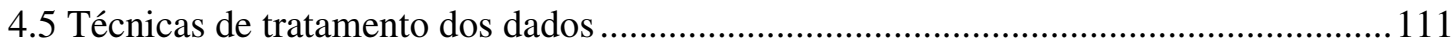

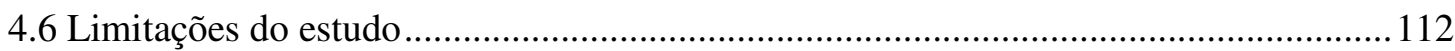

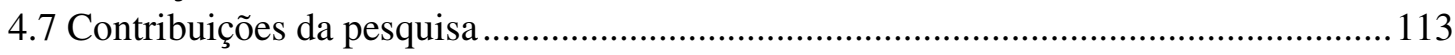

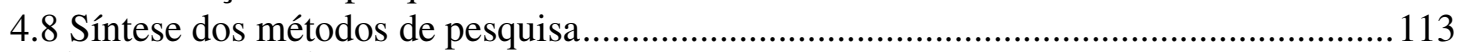

CAPÍTULO 5- ANÁLISE E DISCUSSÃO DOS RESULTADOS ................................. 115

5.1 Caracterização das Instituições Financeiras Analisadas............................................. 116

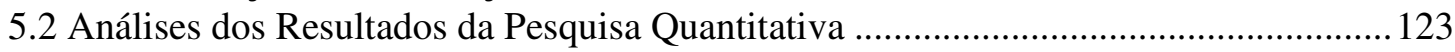

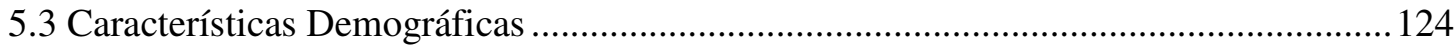

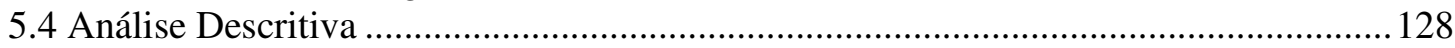

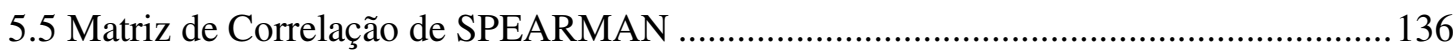

5.6 Mapa de Correlação de PEARSON das variáveis de QVT com liderança e GEP .........138

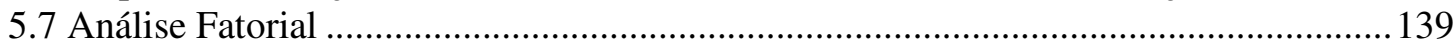

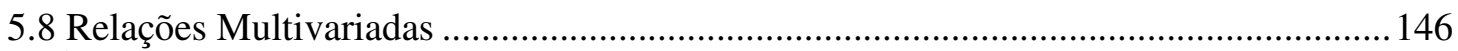

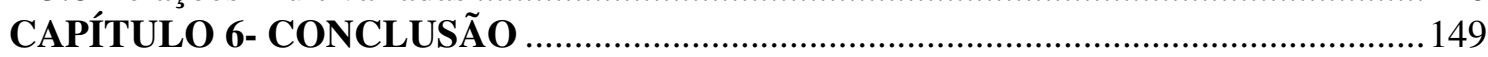

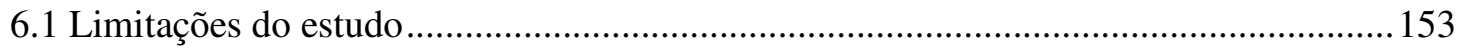

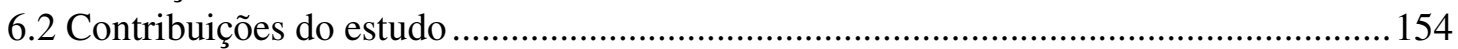

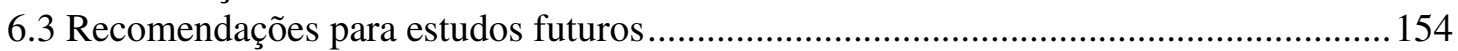

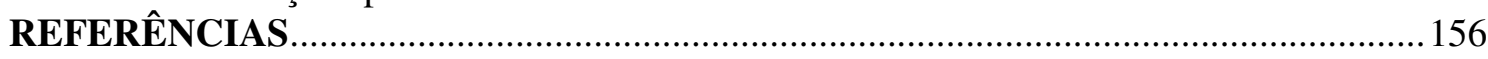




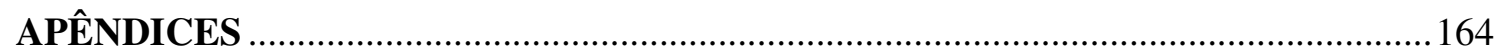

Apêndice 1 - Questionários utilizados na pesquisa de campo ............................................... 165

Apêndice 2 - Roteiro de Entrevista utilizados na pesquisa de campo .................................170

Apêndice 3 - Ficha de Documentação da Entrevista ............................................................ 174

Apêndice 4 - Comunalidades por Questões ........................................................................ 175

Apêndice 5 - Teste Qui-Quadrado de Associação ................................................................ 176 


\section{Lista de Quadros}

Quadro 1 - Relação entre Objetivos, Questões de Pesquisa e Modelo Conceitual ..................17

Quadro 2 - Principais Autores e Pressupostos Conceituais da Pesquisa..................................20

Quadro 3 - Os Papéis administrativos...............................................................................25

Quadro 4 - Abordagens das funções dos gerentes e suas características ..................................26

Quadro 5 - Liderança versus Administração/Gestão ..........................................................27

Quadro 6 - Estilos de Comportamento dos Líderes ................................................................29

Quadro 7 - Evolução das Teorias ou Abordagens de Liderança .............................................30

Quadro 8 - Os Quatro Sistemas Administrativos de Likert e suas Variáveis Comparativas.... 34

Quadro 9 - Bases Teóricas de Pesquisas Derivadas de Estilos e Modelos de Liderança..........37

Quadro 10 - Abordagens Contemporâneas de Liderança.........................................................41

Quadro 11 - Quatro Critérios para avaliar o foco nos resultados ...........................................46

Quadro 12 - Seis Passos para Desenvolver as Habilidades dos Funcionários .........................47

Quadro 13 - Atributos Pessoais que são Fontes de Poder.......................................................52

Quadro 14- Conceitos de Cultura Organizacional e Autores ...............................................54

Quadro 15 - Tipos e Conceitos de Cultura Organizacional ...................................................56

Quadro 16 - Evolução e Práticas da Gestão de Pessoas no Brasil ............................................64

Quadro 17 - Concepção Tradicional X Transformada de Modelos de Gestão de Pessoas ......69

Quadro 18 - Definição dos Papéis de RH ........................................................................72

Quadro 19 - Evolução dos Papéis de RH - década de 1990 e 2000 ......................................73

Quadro 20 - As Escolas de Estratégia, Tipo de Estratégias, Agentes e Liderança ..................76

Quadro 21 - Evolução do conceito de QVT ....................................................................... 80

Quadro 22 - Critérios e Indicadores de QVT do Modelo de Walton........................................81

Quadro 23 - Origens de QVT do Modelo de Westley ...........................................................82

Quadro 24 - Modelo de QVT de Belanger e suas variáveis .................................................83

Quadro 25 - Modelo das Dimensões Básicas da Tarefa ......................................................... 85

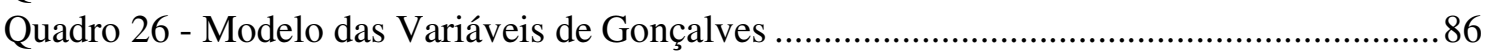

Quadro 27 - Variáveis qualitativas sobre o conceito de Bem-estar organizacional .................90

Quadro 28 - Os significados do trabalho ao longo da história................................................94

Quadro 29 - Padrões de definição do trabalho (MOW) ……...................................................97

Quadro 30 - Mudanças no sistema brasileiro de relações de trabalho ....................................98

Quadro 31 - Estágios no processo de pesquisa .................................................................. 102

Quadro 32 - Quadro síntese do questionário e categorias de análise ...................................... 108

Quadro 33 - Questões de Pesquisa e Modelo Conceitual ..................................................... 108

Quadro 34 - Fontes de evidências e características............................................................ 109

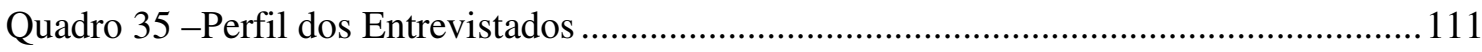

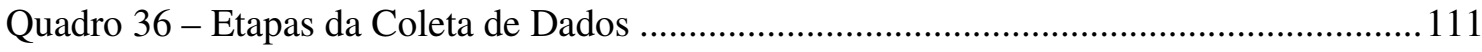

Quadro 37 - Síntese dos métodos da pesquisa desta Tese ................................................113 


\section{Lista de Tabelas}

Tabela 1 - Quantitativo de Instituições por Segmento 2001-2007*.................................... 8

Tabela 2 - Número Totais de Instituições Financeiras por Segmento 2001-2007* ...................9

Tabela 3 - Instituições Financeiras por Origem de Capital 2001-2006 ....................................9

Tabela 4 - Cargo dos Respondentes na Instituição Financeira............................................... 124

Tabela 5 - Distribuição dos Respondentes por Gênero na Instituição Financeira ..................125

Tabela 6 - Distribuição dos Respondentes por Faixa Etária na Instituição Financeira........... 126

Tabela 7 - Distribuição dos Respondentes por Nível de Escolaridade na Instituição Financeira

Tabela 8 - Distribuição dos Respondentes por Número de Dependentes na Instituição

Financeira 127

Tabela 9 - Proporção dos Respondentes que afirmaram importante ou total importância em cada questão - Aspecto Liderança por Instituição Financeira

Tabela 10 - Proporção dos Respondentes que afirmaram concordância parcial ou total em cada questão - Aspecto Gestão de Pessoas por Instituição Financeira

Tabela 11 - Proporção dos Respondentes que afirmaram parcialmente ou totalmente satisfeito em cada questão - Aspectos organizacionais, biológicos, psicológicos e sociais por Instituição Financeira

Tabela 12 - Proporções mais baixas nas variáveis X questões e instituições financeiras......134

Tabela 13 - Matriz de Correlação entre as questões de pesquisa ..........................................137

Tabela 15 - Análise Fatorial dos conjuntos de indicadores e questões ..................................141

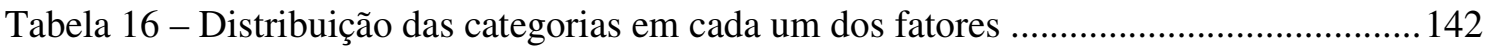

Tabela 17 - Relativização da distribuição das categorias dentro dos fatores .......................... 143

Tabela 18 - Relativização da distribuição das categorias e como elas se distribuem nos fatores

143

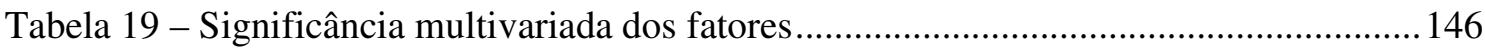

Tabela 20 - Estimativas dos coeficientes da MANOVA - Fator Aspectos Biológicos .......... 146

Tabela 21 - Estimativas dos coeficientes da MANOVA - Fator Aspectos Organizacionais 147

Tabela 22 - Estimativas dos coeficientes da MANOVA - Fator Aspectos Psicológicos ...... 147

Tabela 23 - Estimativas dos coeficientes da MANOVA - Fator Aspectos Sociais 


\section{Lista de Ilustrações}

Ilustração 1 - Definição Operacional da Pesquisa..................................................................18

Ilustração 2 - Impacto da Cultura no Desempenho e na Satisfação dos Funcionários.............59

Ilustração 3 - Fluxo do conceito dinâmico de Planejamento Estratégico de RH .....................66

Ilustração 4 - Integração da Estratégia de RH na estratégia da empresa: etapas do processo de

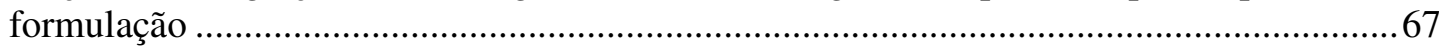

Ilustração 5 - Qualidade de Vida no Trabalho X Produtividade...............................................8 84

Ilustração 6 - Triângulo do Bem-Estar-Organizacional (BEO) e suas Variáveis......................91

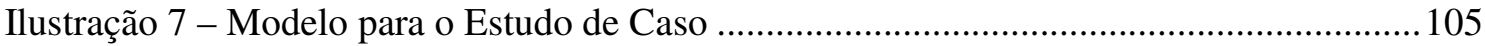

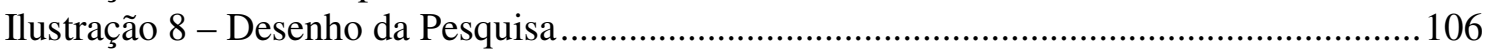


CAPÍTULO 1- INTRODUÇÃO

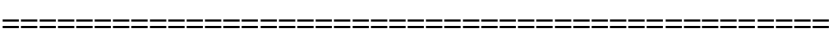


1.1 Uma leitura preliminar do contexto

As organizações estão inseridas em uma economia global onde os mercados mundiais interagem, não se limitando às fronteiras regionais ou nacionais. Atualmente é irrelevante especificar o país de origem das empresas, as quais perderam quase que totalmente os limites de operação de suas atividades (ROBBINS, 2005).

São diversas causas atribuídas à globalização, como: i) há três décadas, as fronteiras nacionais podiam isolar as empresas das pressões competitivas estrangeiras, fato que não ocorre nos dias de hoje; ii) a globalização significa aumento da competição para quase todo tipo de organização; iii) as duas principais forças motrizes da globalização foram a procura de novos mercados e os esforços para a redução de custos; iv) a economia globalizada também tornou os países independentes, devido ao livre trânsito de capitais; v) a formação de blocos econômicos, como Mercado Comum Europeu, Associação Norte-Americana de Livre Comércio, Mercosul, Associação das Nações do Sudeste Asiático, entre outros.

O mesmo autor relata as conseqüências positivas e negativas da globalização, como: a) diversidade cultural e da mão-de-obra, ou seja, crescimento das mulheres na força de trabalho no Brasil e no Mundo; b) mudança nas expectativas da sociedade - exigência que as empresas sejam organizações responsáveis, com projetos de responsabilidade social; c) precarização do trabalho, com o trabalho flexível e temporário, terceirização, cooperativas de trabalho, trabalho informal etc.; d) redução do quadro de pessoal, através da eliminação de níveis hierárquicos das organizações, entre outras.

Segundo Dutra et al (2001) o processo de globalização foi acelerado pelas novas conquistas nas áreas de telecomunicações e transportes e teve no setor bancário um de seus principais agentes, com conseqüências diretas e profundas, em decorrência da interdependência de mercado mundial e do fluxo de capital cada vez mais intenso e globalizado. Isto acabou se tornando peça fundamental no equilíbrio dos balanços de pagamentos e nas próprias políticas monetárias dos Governos.

A globalização também trouxe reflexos no sistema financeiro e no setor bancário, onde as recentes alterações no cenário econômico, juntamente com a alta concentração das instituições financeiras, demonstram a dinâmica do setor. O sistema financeiro nacional é composto por três agentes econômicos: órgãos normativos, entidades supervisoras e operadoras. Os órgãos normativos que exercem o papel de estabelecer leis e regulamentos para o setor são o Conselho Monetário Nacional de Seguros Privados e o Conselho de Gestão 
da Previdência Complementar. Nas entidades supervisoras com papel de fiscalização estão o Banco Central do Brasil, a Comissão de Valores Mobiliários, a Superintendência de Seguros Privados e a Secretaria de Previdência Complementar. Os operadores são constituídos por instituições financeiras bancárias e demais instituições financeiras.

São diversos tipos de Instituições que atuam no Brasil. No final de Setembro de 2007 totalizavam 2.441 (duas mil, quatrocentos e quarenta e uma) realizando operações (BANCO CENTRAL DO BRASIL, 2008). Apresenta-se na Tabela 1 o quantitativo de instituições por segmento existentes no Brasil.

Tabela 1 - Quantitativo de Instituições por Segmento 2001-2007*

\begin{tabular}{|c|c|c|c|c|c|c|c|c|}
\hline \multirow[t]{2}{*}{ Segmento } & \multirow{2}{*}{ sigla } & 2001 & 2002 & 2003 & 2004 & 2005 & 2006 & 2007 \\
\hline & & Dez & Dez & Dez & Dez & Dez & Dez & Set \\
\hline Banco Múltiplo & BM & 153 & 143 & 141 & 139 & 138 & 137 & 134 \\
\hline Banco Comercial (1) & $\mathrm{BC}$ & 28 & 23 & 23 & 24 & 22 & 21 & 20 \\
\hline Banco de Desenvolvimento & $\mathrm{BD}$ & 4 & 4 & 4 & 4 & 4 & 4 & 4 \\
\hline Caixa Econômica & $\mathrm{CE}$ & 1 & 1 & 1 & 1 & 1 & 1 & 1 \\
\hline Banco de Investimento & $\mathrm{BI}$ & 20 & 23 & 21 & 21 & 20 & 18 & 17 \\
\hline $\begin{array}{l}\text { Sociedade de Crédito Financiamento e } \\
\text { Investimento }\end{array}$ & SCFI & 42 & 46 & 47 & 46 & 50 & 51 & 53 \\
\hline $\begin{array}{l}\text { Sociedade Corretora de Títulos e Valores } \\
\text { Mobiliários }\end{array}$ & SCTVM & 177 & 161 & 147 & 139 & 133 & 116 & 108 \\
\hline Sociedade Corretora de Câmbio & SCC & 43 & 42 & 43 & 47 & 45 & 48 & 47 \\
\hline $\begin{array}{l}\text { Sociedade Distribuidora de Títulos e } \\
\text { Valores Mobiliários }\end{array}$ & SDTVM & 159 & 151 & 146 & 138 & 134 & 133 & 134 \\
\hline Sociedade de Arrendamento Mercantil & SAM & 72 & 65 & 58 & 51 & 45 & 41 & 39 \\
\hline $\begin{array}{l}\text { Sociedade de Crédito Imobiliário (2) e } \\
\text { Associação de Poupança e Empréstimo }\end{array}$ & $\begin{array}{l}\text { SCI e } \\
\text { APE }\end{array}$ & 18 & 18 & 18 & 18 & 18 & 18 & 18 \\
\hline Companhia Hipotecária & $\mathrm{CH}$ & 7 & 6 & 6 & 6 & 6 & 6 & 6 \\
\hline Agência de Fomento & $\begin{array}{c}\mathrm{AG} \\
\mathrm{FOM}\end{array}$ & 9 & 10 & 11 & 12 & 12 & 12 & 12 \\
\hline Sub & tal: & 733 & 693 & 666 & 646 & 628 & 606 & 593 \\
\hline Cooperativa de Crédito & COOP & 1.379 & 1.430 & 1.454 & 1.436 & 1.439 & 1.452 & 1.465 \\
\hline $\begin{array}{l}\text { Sociedade de Crédito ao } \\
\text { Microempreendedor }\end{array}$ & SCM & 23 & 37 & 49 & 51 & 55 & 56 & 54 \\
\hline Sub & tal: & 2.135 & 2.160 & 2.169 & 2.133 & 2.122 & 2.114 & 2.112 \\
\hline Sociedade Administradora de Consórcios & CONS & 399 & 376 & 365 & 364 & 342 & 333 & 329 \\
\hline & otal & 2.534 & 2.536 & 2.534 & 2.497 & 2.464 & 2.447 & 2.441 \\
\hline
\end{tabular}

Fonte: Transcrição integral de Banco Central do Brasil (BACEN) -

http://www.bcb.gov.br/htms/Deorf/d200709/quadro1.asp em 07/09/2008. * Dados até 30/09/2007.

Observa-se a redução de 3,67\% no total das instituições no período de dezembro de 2001 a setembro de 2007 no Brasil. Isso demonstra a concentração no setor.

No território brasileiro atuavam, no final de Setembro de 2007, um total de 134 (cento e trinta e quatro) instituições financeiras do tipo privadas, públicas ou bancos múltiplos, que realizavam as operações ativas, passivas e acessórias das diversas organizações financeiras (BANCO CENTRAL DO BRASIL, 2008). Demonstra-se na Tabela 2 uma síntese dos tipos de Bancos por segmento existentes no Brasil. 
Tabela 2 - Número Totais de Instituições Financeiras por Segmento 2001-2007*

\begin{tabular}{l|c|c|c|c|c|c|c}
\hline \multicolumn{1}{c}{ Tipos de Inst. Financeiras } & $\mathbf{2 0 0 1}$ & $\mathbf{2 0 0 2}$ & $\mathbf{2 0 0 3}$ & $\mathbf{2 0 0 4}$ & $\mathbf{2 0 0 5}$ & $\mathbf{2 0 0 6}$ & $\mathbf{2 0 0 7}$ \\
\hline Bancos Múltiplos & 153 & 143 & 141 & 139 & 138 & 137 & 134 \\
\hline Banco Comercial & 28 & 23 & 23 & 24 & 22 & 21 & 20 \\
\hline Banco de Desenvolvimento & 4 & 4 & 4 & 4 & 4 & 4 & 4 \\
\hline Caixa Econômica & 1 & 1 & 1 & 1 & 1 & 1 & 1 \\
\hline Total & $\mathbf{1 8 6}$ & $\mathbf{1 7 1}$ & $\mathbf{1 6 9}$ & $\mathbf{1 6 8}$ & $\mathbf{1 6 5}$ & $\mathbf{1 6 3}$ & $\mathbf{1 5 9}$ \\
\hline
\end{tabular}

Fonte: Transcrição integral de Banco Central do Brasil (BACEN) -

http://www.bancocentral.gov.br/?QEVSFN200705 em 07/09/2008

* Dados até 30/09/2007.

O quadro geral das Instituições Financeiras no Brasil teve uma redução de 14,52\% no período de dezembro de 2001 a setembro de 2007. De acordo com a Febraban (2007) a estabilidade do setor bancário brasileiro sinalizou uma consolidação do processo de fusões e incorporações no mercado financeiro ocorrido nas últimas duas décadas. A competitividade entre os bancos deve se acentuar no tempo como forma de conquista de maiores espaços. Nesta perspectiva, a tecnologia deverá exercer um papel cada vez mais importante na oferta de novos serviços e na gestão mais eficiente de suas estruturas.

Tabela 3 - Instituições Financeiras por Origem de Capital 2001-2006

\begin{tabular}{l|c|c|c|c|c|c}
\hline \multicolumn{1}{c}{ Origem de Capital } & $\mathbf{2 0 0 1}$ & $\mathbf{2 0 0 2}$ & $\mathbf{2 0 0 3}$ & $\mathbf{2 0 0 4}$ & $\mathbf{2 0 0 5}$ & $\mathbf{2 0 0 6}$ \\
\hline Privados nacionais com e sem participação estrangeira & 95 & 87 & 88 & 88 & 84 & 85 \\
\hline Privados estrangeiros e com controle estrangeiro & 72 & 65 & 62 & 62 & 63 & 61 \\
\hline Públicos federais e estaduais & 15 & 15 & 15 & 14 & 14 & 13 \\
\hline Número total de bancos & $\mathbf{1 8 2}$ & $\mathbf{1 6 7}$ & $\mathbf{1 6 5}$ & $\mathbf{1 6 4}$ & $\mathbf{1 6 1}$ & $\mathbf{1 5 9}$ \\
\hline
\end{tabular}

Fonte: Transcrição integral de http://www.febraban.org.br/Arquivo/Servicos/Dadosdosetor/2007/item15.asp em 23/08/2007

A tabela 3 apresenta a evolução das Instituições Financeiras por origem de capital entre dezembro de 2001 e dezembro de 2006, excluindo-se os Bancos de Desenvolvimento. Nesse período observa-se uma redução de $10,53 \%$ no total dos bancos privados nacionais com e sem participação estrangeira; redução de 15,28\% nos bancos privados estrangeiros e com controle estrangeiro, redução de $13,33 \%$ nos bancos públicos federais e estaduais, e redução de $12,64 \%$ no total do número de bancos no Brasil.

A distribuição das instituições financeira por origem de capital no final de dezembro de 2006 era: os bancos privados nacionais com e sem participação estrangeira representavam $53,46 \%$, os bancos estrangeiros e com controle estrangeiro eram 38,36\% e os bancos públicos federais e estaduais somavam-se $8,18 \%$ do total das instituições. 
A tendência mundial de consolidação do setor bancário também é seguida no sistema brasileiro. Destaca-se a permanência de bancos nacionais na liderança do mercado financeiro, com substanciais investimentos em tecnologia e na capacitação de seus profissionais.

No final de 2006 o setor bancário representava mais de $10 \%$ do produto interno bruto brasileiro em ativos totais. O sistema tinha mais de 1,76 trilhão em ativos totais, o patrimônio líquido total cresceu $21,4 \%$ em 2006 e atingiu o montante de $\mathrm{R} \$ 185,9$ bilhões; teve cerca de 900 bilhões de reais em captação de recursos de terceiros com um crescimento de $18 \%$ em relação ao ano anterior, gerando mais de 424 mil empregos diretos em vinte e oito instituições pesquisadas, sendo 47,7\% desses profissionais, mulheres (FEBRABAN, 2007).

Segundo a mesma federação, em 2006 houve crescimento de 7,9\% no número de contas correntes, que totalizaram 102,6 milhões. Desse montante, 73,7 milhões são contas ativas, ou seja, tiveram alguma movimentação no período de seis meses. O número de contas de poupança somou 75 milhões, que representou uma expansão de 4,5\%. O número de clientes de Internet Banking, empresas e indivíduos, praticamente se estabilizou em 2006.

Destaque para o aumento de 9,24\% no número de dependências bancárias (rede de atendimento) de dezembro de 2005 para 2006, com um total de 134.114 pontos de atendimento, trazendo conveniência aos clientes e usuários dos bancos, como é o caso das agências bancárias, postos tradicionais, postos eletrônicos, correspondentes bancários como lotéricas e bancos postais (FEBRABAN, 2007).

Dessa forma, o sistema financeiro está dotado de estratégias de inovação tecnológica e rapidez de respostas aos mercados, originários da globalização e da alta competitividade entre suas organizações. Ele visa permanentemente a efetividade de seu quadro de pessoal, cada vez mais qualificado e responsável pelos resultados finais das instituições financeiras.

O sistema bancário brasileiro passou nos últimos dez anos por mudanças profundas em decorrência da adequação à nova ordem econômica vigente, originando um quadro de concentração de instituições acentuado neste setor. Isto em decorrência das vantagens tecnológicas, de custo, de qualidade, de atendimento e distribuição, sendo estes, elementos que induzem a concentração, fusão e protegem o próprio setor bancário de novos entrantes (FEBRABAN, 2007).

Neste cenário, a implementação de estratégias é fundamental para o sucesso organizacional. Mas o que é estratégia? De acordo com Mintzberg (2000) e Mintzberg, Ahlstrand e Lampel (2000), o termo estratégia pode ser utilizado e agrupado em quatro possibilidades: estratégia como plano, como padrão (de comportamento estratégico), como 
posição (localização no setor competitivo) e como perspectiva (visão dos estrategistas e da organização). Tais definições podem ser interpretadas como independentes uma da outra, mas não concorrem entre si e muitas vezes se complementam durante a tarefa de compreender a natureza da estratégia de determinada organização.

A estratégia organizacional é o conjunto formado pela missão, visão, com objetivos de longo prazo e as metas de curto prazo, com políticas e programas de ação estabelecidos dentro de uma seqüência coerente e que levam em consideração a alocação de recursos correspondentes a cada programa; tudo definido pelos estrategistas ou gerentes responsáveis pela formulação da estratégia da organização (ALBUQUERQUE, 2002; MUNIZ E DA SILVA, 2004).

De acordo com Muniz e da Silva (2004), nem sempre a formulação de uma estratégia adequada significa o sucesso da companhia e de seus altos executivos. Segundo os mesmos autores, de nada adianta a melhor estratégia se esta não é aplicada de maneira consistente na organização.

Nesse sentido, a gestão estratégica de pessoas envolve a formulação, implementação e avaliação de resultados para o alcance de vantagens competitivas, baseadas na gestão de pessoas. A formulação de políticas de gestão de pessoas deve estar alinhada com as estratégias organizacionais no sentido de contribuir para o alcance dos resultados do negócio.

Segundo Anthony; Perrewé e Kacmar (1996, p. 67-68) ${ }^{1}$, a área de gestão de pessoas tem destaque na formulação das estratégias organizacionais, pois:

\begin{abstract}
A área de gestão de pessoas está em melhor posição do que qualquer outro setor da organização para fazer a análise do ambiente de recursos humanos e do mercado de trabalho. A área de gestão de pessoas pode ajudar a organização a obter a informação ambiental e alimentá-la aos responsáveis pelas decisões estratégicas. $\mathrm{Na}$ realidade, a área de gestão de pessoas pode ter um papel importante no processo de decisão como explicado anteriormente. A área de gestão de pessoas tem também a responsabilidade de obter a informação organizacional interna para a consideração dos responsáveis pelas decisões estratégicas. (tradução do pesquisador)
\end{abstract}

Nesse sentido, destacam-se as políticas de desenvolvimento de lideranças, pois de acordo com Goleman (2002, p. 55-59) diversos estilos de liderança têm efeito positivo no clima e nos resultados organizacionais. Ele sustenta que os líderes ou executivos mais eficazes, além de apresentarem habilidade técnica e raciocínio analítico significativos, têm

\footnotetext{
${ }^{1}$ Human resources are in the best position of any unit in the organization to scan the environment for human resources and labor market issues. Human resources can help the organization to obtain environmental information and feed it to key decision makers. In fact, Human resources may play a major role in making the decision as explained above. Human resources also have the responsibility of obtaining internal organizational information for consideration by strategic decision makers.
} 
como requisito comum e indispensável um alto grau de inteligência emocional, conceito que reúne a capacidade de trabalhar em equipe e a eficiência na promoção de mudanças; é composta de cinco elementos: autoconsciência, autocontrole, motivação, empatia e aptidão social.

Ulrich (1999) e Ulrich; Zenger e Smallwood (2000) afirmam que o líder poderá conduzir grupos de subordinados para determinados resultados, mirando as dimensões da organização, clientes, empregados, e investidores.

Contribuindo com esse entendimento, Montana e Charnov (1998, p. 221) afirmam que "um líder bem sucedido usa o poder de influenciar os outros eficazmente, e é importante que ele entenda as fontes e os usos do poder para realçar a função de liderança". Contudo, pode-se supor que alguns líderes também podem trazer malefícios para a empresa e para os funcionários, dependendo de sua forma de liderar, podendo causar influências negativas no clima e nos resultados empresariais como apontado nas pesquisas de Ulrich (1999) e Goleman (2002).

Green, Hassan, Immelt, Marks e Meiland (2003) afirmam que um líder se enxerga como o fomentador principal de talento, não importa quão grande a companhia seja. Ele dedica muito tempo e energia a construir redes pessoais para consolidar sua influência nos liderados da organização.

Um dos aspectos relevantes de influência dos líderes é o nível de satisfação dos colaboradores com o bem-estar organizacional (BEO). Destaca-se a interdependência de fatores biológicos, psicológicos, sociais e organizacionais na satisfação do BEO, denominando o modelo de Biopsicossocial e organizacional. O fator biológico está relacionado às características físicas e genéticas adquiridas ao nascer; já no contexto organizacional, o mesmo foca aspectos do ambiente de trabalho em que o ser humano está inserido; o fator psicológico refere-se a processos afetivos e emocionais, conscientes ou não, relacionados à realização do trabalho; a dimensão social procura revelar valores socioeconômicos, culturais e valores coletivos que possam interferir na realização das atividades dentro da organização; o fator organizacional foca o investimento em pessoas, o humanismo e a competitividade (LIMONGI-FRANÇA, 1996, 2004, 2005).

Nesse contexto, justifica-se a análise da liderança e suas relações na gestão estratégica de pessoas e bem-estar organizacional nas duas instituições financeiras internacionais investigadas. 


\subsection{Organização dos capítulos}

Apresenta-se nessa seção, a organização dos capítulos desse projeto de Tese. A primeira parte é denominada I - Introdução, que envolve uma leitura preliminar do contexto com as causas e consequiências atribuídas a globalização; os reflexos no sistema financeiro brasileiro e no setor bancário; a evolução das instituições financeiras por segmento e por origem de capital e a classificação das instituições financeiras por ativos totais.

No capítulo II - O problema de pesquisa compreende a definição da situação problema e os objetivos da pesquisa; a relação entre questões de pesquisa e objetivos; as definições teóricas e operacionais dos conceitos relevantes envolvendo a gestão estratégica de pessoas, os estilos de liderança e poder, e os níveis de satisfação com o bem-estar organizacional (BEO) e os pressupostos conceituais fundamentados no modelo de liderança embasada em resultados de Ulrich (1999), gestão estratégica de pessoas de Albuquerque (1999, 2002) e BEO de Limongi-França $(1996,2004,2005,2007)$.

Capítulo III - Fundamentação teórica, que apresenta os principais autores e conceitos que apóiam o desenvolvimento desta pesquisa como líder e liderança; poder individual e organizacional e suas variáveis; os fundamentos de cultura organizacional; a gestão estratégica de pessoas; o bem-estar organizacional e qualidade de vida no trabalho; as relações de trabalho com: os significados do trabalho ao longo da história; as mudanças no sistema brasileiro de relações de trabalho e as relações de trabalho e a internacionalização.

O capítulo, IV - Métodos de pesquisa, esclarece a natureza do estudo e a escolha do método envolvendo: os estágios no processo de pesquisa; a classificação da pesquisa desse estudo; o modelo para o estudo de caso; o desenho da pesquisa; a definição dos sujeitos da pesquisa; os instrumentos de pesquisa; as fontes de evidências e suas características; a coleta de dados; as técnicas de tratamentos dos dados; as limitações; as principais contribuições da pesquisa e a síntese dos métodos de pesquisa.

No capítulo V - Análise e discussão dos resultados, demonstram a caracterização das instituições financeiras analisadas e os resultados das pesquisas com as características demográficas; as análise descritivas; a matriz de Correlação de SPEARMAN e o mapa de correlação de PEARSON das variáveis de QVT com liderança e GEP; a análise Fatorial e as relações multivariadas. 
O último capítulo é o VI - Considerações finais, que fornece um fechamento do trabalho desenvolvido com a síntese dos resultados, limitações do estudo, principais contribuições da pesquisa e recomendações para estudos futuros. 
CAPÍTULO 2- O PROBLEMA DE PESQUISA

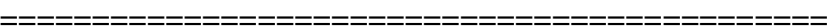




\subsection{Definição da Situação-Problema}

No contexto atual, o papel gerencial abrange de uma maneira substancial as atividades de tomada de decisão, de planejamento, da gestão de recursos organizacionais, da gestão de pessoas, entre outras. Segundo Schermerhorn Jr (1996, p. 11), "atualmente gerentes em todos os cenários são solicitados a obter alta produtividade e criar ambientes de alta qualidade para a vida no trabalho, para uma força de trabalho cada vez mais diversificada". Dessa forma, o estilo do gerenciamento adotado em uma organização poderá afetar positivamente ou não os resultados organizacionais.

Assim, a definição da situação-problema envolve a gestão estratégica de pessoas das Instituições Financeiras Internacionais, a orientação para liderança de resultados e os níveis de satisfação dos líderes com os aspectos de bem-estar organizacional.

\subsection{Objetivos da Pesquisa}

A liderança pode ser um diferencial competitivo no mundo dos negócios, especialmente em tempos difíceis e turbulentos, pois o líder poderá contribuir significativamente para formação de novas competências e resultados em processos competitivos de mercados (DAFT, 1999; LIMONGI-FRANÇA, ARELLANO, 2002).

Esta pesquisa tem como objetivo principal analisar o grau de importância da liderança orientada para resultados na percepção dos profissionais da área de Gestão de Pessoas de duas Instituições Financeiras Internacionais que atuam no Brasil e suas relações com a Gestão Estratégica de Pessoas e com os níveis de satisfação dos aspectos: organizacionais, biológicos, psicológicos e sociais, dos executivos participantes.

\subsection{Questões de Pesquisa}

Diante do contexto de globalização, sistema financeiro e bancário, gestão estratégica de pessoas, estilos de liderança e bem-estar organizacional, são apresentadas as questões de pesquisa que direcionam este estudo, bem como a sua relação com os objetivos da pesquisa conforme o Quadro 1 a seguir. 
Quadro 1 - Relação entre Objetivos, Questões de Pesquisa e Modelo Conceitual

\begin{tabular}{|l|l|l|}
\hline \multicolumn{1}{|c|}{ Objetivos Específicos } & \multicolumn{1}{|c|}{ Questões de Pesquisa } & \multicolumn{1}{c|}{ Modelo Conceitual } \\
\hline $\begin{array}{l}\text { a) Identificar o grau de } \\
\text { importância da liderança } \\
\text { orientada para resultados na } \\
\text { percepção dos profissionais } \\
\text { da área de Gestão de Pessoas } \\
\text { dos bancos pesquisados; }\end{array}$ & $\begin{array}{l}\text { Quais são os graus de importância da } \\
\text { liderança orientadas para resultados dos } \\
\text { profissionais da área de Gestão de Pessoas de } \\
\text { duas Instituições Financeiras Internacionais? }\end{array}$ & $\begin{array}{l}\text { Liderança embasada em } \\
\text { Resultados. Ulrich (1999) e } \\
\text { Ulrich; Zenger e Smallwood } \\
(2000) .\end{array}$ \\
\hline $\begin{array}{l}\text { b) Analisar as políticas de } \\
\text { gestão estratégica de pessoas } \\
\text { dos bancos múltiplos; }\end{array}$ & $\begin{array}{l}\text { a) Quais são os graus de concordância nas } \\
\text { políticas de gestão estratégica de pessoas? }\end{array}$ & $\begin{array}{l}\text { Gestão Estratégica de } \\
\text { Pessoas. Albuquerque (1999, } \\
\text { 2002) }\end{array}$ \\
\hline $\begin{array}{l}\text { c) Identificar os níveis de } \\
\text { satisfação com os aspectos de } \\
\text { bem-estar organizacional dos } \\
\text { executivos participantes. }\end{array}$ & $\begin{array}{l}\text { b) Quais são os níveis de satisfação com os } \\
\text { aspectos: organizacionais, biológicos, } \\
\text { psicológicos e sociais dos executivos } \\
\text { pesquisados? }\end{array}$ & $\begin{array}{l}\text { Bem-estar organizacional. } \\
\text { Limongi-França (1996, } \\
\text { 2004, 2005, 2007) }\end{array}$ \\
\hline
\end{tabular}

Fonte: adaptado pelo pesquisador. Transcrição parcial.

Os objetivos específicos deste estudo visam identificar e analisar as variáveis de pesquisa e são necessárias diversas questões de investigação para se atingir tais objetivos. Estas questões são fundamentadas em modelos consolidados na literatura de autores como Ulrich (1999) e Ulrich; Zenger e Smallwood (2000), Albuquerque (1999, 2002) e LimongiFrança $(1996,2004,2005,2007)$, de onde foram adaptadas as questões de pesquisa.

\subsection{Hipóteses da Pesquisa}

São apresentadas nesse item as hipóteses de trabalho que são testadas na pesquisa com a utilização de técnicas estatísticas.

Inicialmente este estudo buscou identificar as dimensões dos aspectos da qualidade de vida no trabalho, gestão estratégica de pessoas e liderança. Assim, a hipótese nula é:

$\mathrm{H}_{0}$ - Não existe relação entre os aspectos qualidade de vida no trabalho e gestão estratégica de pessoas e liderança.

Após a confirmação, ou não, dessa hipótese esta pesquisa busca estabelecer comparações entre grau de satisfação com os aspectos da qualidade de vida, gestão de pessoas, liderança orientada para resultados nas duas instituições financeiras analisadas.

$\mathrm{H}_{1}$ - A proporção de pessoas que possuem alto grau de satisfação com os aspectos qualidade de vida no trabalho é a mesma nas duas instituições; 
$\mathrm{H}_{2}$ - A proporção de pessoas que concordam com a gestão estratégica de pessoas de comprometimento (transformada) é a mesma nas duas instituições;

$\mathrm{H}_{3}$ - A proporção de pessoas que atribuem importância a liderança orientada para resultados é a mesma nas duas instituições.

2.5 Definições teórica e operacional dos conceitos relevantes

Esta pesquisa utiliza como suporte teórico o modelo de Liderança embasada em resultados, como definido por Ulrich (1999) e Ulrich; Zenger e Smallwood (2000). A liderança descreve os resultados específicos obtidos pelos líderes. Estes são detentores de caráter, moral, integridade e energia, além de pensamento estratégico.

A definição teórica dos termos relevantes pode ser visualizada na ilustração 1 a seguir:

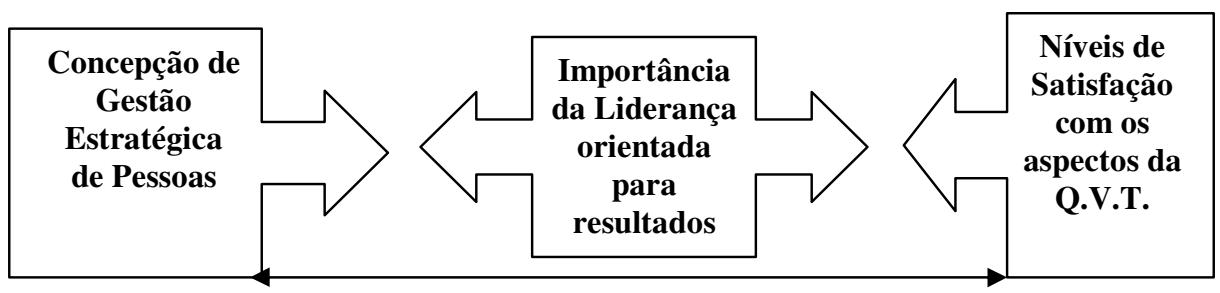

Ilustração 1 - Definição Operacional da Pesquisa

Fonte: o pesquisador

Assim, "A liderança para resultados significa a consecução de algo" (ULRICH ZENGER; SMALLWOOD, 2000, p. 45). É importante salientar que os resultados aqui referidos estão voltados para os quatro principais stakeholders, a saber: empregados, organização, clientes e investidores.

Para avaliar tais resultados, para Ulrich; Zenger e Smallwood (2000, p. 46) são necessários quatro critérios: os resultados almejados equilibrados, estratégicos, duradouros e altruístas, ou seja, que contemplam os quatro grupos principais de stakeholders, "contribuem para a diferenciação e vantagem competitiva da organização", "não sacrificam o sucesso de longo prazo pelos ganhos de curto prazo" e "trabalharão para o benefício do todo mais amplo, e não apenas para o seu grupo ou área". Isto significa que o desenvolvimento da nitidez estratégica, através do foco do negócio e da proposição de valor, serve de base para o equilíbrio dos resultados almejados. A organização é feita de pessoas, então a sinergia é parte do processo para obtenção de resultados. 
A gestão estratégica de pessoas baseia-se no modelo fundamentado na literatura por Albuquerque $(1999,2002)$, que apresenta a gestão de pessoas por comprometimento e o tradicional.

A concepção Econômica (Tradicional) considera o ser humano como fator de produção, como mais um recurso e como número. Já a concepção Transformada (Comprometimento) contempla o ser humano enquanto pessoa, parceira efetiva na busca dos objetivos organizacionais e de agregação de valor à sociedade. Essas visões devem ser consideradas e afetam profundamente a forma da realização da gestão estratégica de pessoas nas organizações.

Com relação aos fatores de satisfação do bem-estar organizacional (BEO) foi utilizado o modelo de Limongi-França (1996, 2004, 2005), no qual os fatores de satisfação são biológicos, psicológicos, sociais e organizacionais relacionados ao trabalho.

Segundo Limongi-França (2005, p.7), a variável biológica refere-se às características físicas herdadas ou adquiridas pelo ser humano, ao nascer e durante toda a vida. Essa variável considera o "metabolismo, resistências e vulnerabilidades dos órgãos ou sistemas".

A variável psicológica considera os processos afetivos, emocionais e de raciocínio, conscientes ou inconscientes, que formam a personalidade da pessoa ou o seu modo de perceber e se posicionar diante das pessoas e das circunstâncias do dia-a-dia. A variável social compreende os valores, as crenças, o papel na família, no trabalho e em todos os grupos e comunidades a que cada pessoa pertence e participa. A variável organizacional considera a produtividade, o humanismo e o investimento no ser humano.

As variáveis foram selecionadas a partir da visão biopsicossocial e organizacional em relação às ações das empresas: programas, campanhas, gestão, levantamentos e controle de resultados.

É normalmente analisado o grau de satisfação dos colaboradores quanto à capacidade de uma gestão compatível com as necessidades organizacionais voltadas para a performance do seu bem-estar numa visão global e abrangente.

\subsection{Pressupostos conceituais}

No quadro 2 são apresentados os pressupostos conceituais desta pesquisa envolvendo a liderança embasada em resultados modelo de Ulrich, Zenger e Smallwood (2000), gestão estratégica de pessoas (Modelo Tradicional ou de Comprometimento - Albuquerque, 1999, 
2002) e do bem-estar organizacional (fatores biológicos, psicológicos, sociais e organizacionais - Limongi-França, 1996, 2004 e 2005).

Quadro 2 - Principais Autores e Pressupostos Conceituais da Pesquisa

\begin{tabular}{|l|l|l|}
\hline \multicolumn{1}{|c|}{ Autores } & \multicolumn{1}{c|}{ Modelo } & \multicolumn{1}{c|}{ Conceito } \\
\hline $\begin{array}{l}\text { Ulrich, Zenger e } \\
\text { Smallwood (2000), Ulrich } \\
\text { Robertson (2003) }\end{array}$ & $\begin{array}{l}\text { Liderança } \\
\text { embasada em } \\
\text { Resultados }\end{array}$ & $\begin{array}{l}\text { Marca de liderança que descreve os resultados } \\
\text { específicos que os líderes obtêm. Os líderes são } \\
\text { detentores de caráter, moral, integridade e energia, além } \\
\text { de pensamento estratégico. }\end{array}$ \\
\hline Albuquerque (1999, 2002) & $\begin{array}{l}\text { Gestão Estratégica } \\
\text { de Pessoas }\end{array}$ & $\begin{array}{l}\text { Envolve a formulação, implementação e avaliação de } \\
\text { resultados para o alcance de vantagens competitivas, } \\
\text { baseadas na gestão de pessoas. Podem ser gestão de } \\
\text { estratégias tradicionais e transformadas de políticas de } \\
\text { pessoas. }\end{array}$ \\
\hline $\begin{array}{l}\text { Limongi-França (1996, } \\
2004,2005,2007)\end{array}$ & $\begin{array}{l}\text { São considerados os fatores de satisfação biológicos, } \\
\text { psicológicos, sociais e organizacionais relacionados ao } \\
\text { trabalho. }\end{array}$ \\
\hline
\end{tabular}

Fonte: adaptado pelo pesquisador. Transcrição parcial.

Os conceitos apresentados são contemporâneos, pois foram idealizados na última década e aplicados por diversos pesquisadores nos Estados Unidos e no Brasil. A combinação dessas variáveis - liderança embasada em resultados, gestão estratégica de pessoas e bemestar organizacional, não foi realizada por nenhum estudo identificado na literatura. 
CAPÍTULO 3- FUNDAMENTAÇÃO TEÓRICA

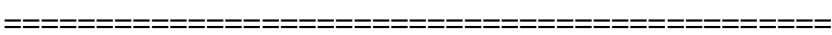


Apresenta-se nesse capítulo a fundamentação teórica com os principais autores e conceitos que apóiam o desenvolvimento desta pesquisa com as evoluções no decorrer da história, modelos/abordagens e seus diversos aspectos, envolvendo as variáveis independentes, intervenientes e dependentes de pesquisa.

Os temas abordados no item 3.1 são líder e liderança, envolvendo: os aspectos da liderança versus administração/gestão; os estilos de comportamentos dos líderes; a evolução das teorias ou abordagens de liderança; os sistemas administrativos de Likert; as bases teóricas de pesquisas derivadas de estilos e modelos de liderança; as abordagens contemporâneas de liderança; a liderança orientada para resultados e os quatro critérios para avaliar o foco nos resultados, e os seis passos para desenvolver as habilidades dos funcionários.

Em uma breve pesquisa realizada utilizando-se o ProQuest powered by ProQuest ${ }^{\circledR}$ Smart Search em 28/10/2007, com a base de dados Dissertations \& Theses, ABI/INFORM Global, foram identificados 26.686 documentos encontrados para Leadership (liderança) e Leader (líder) considerando todas as fontes disponíveis entre documentos completos e resumos. Desse total são 9.431 documentos encontrados de publicações acadêmicas, 3.878 documentos encontrados de revistas, 12.102 documentos de publicações comerciais, 592 documentos de jornais, 24 documentos de referência/reportagens e 659 documentos encontrados de dissertações/teses. Portanto, observa-se uma vasta literatura internacional sobre essa temática.

No tópico 3.2 são apresentados os conceitos de poder; as diferenças entre poder e autoridade; os tipos de poder organizacional e suas fontes; as bases do poder; os atributos pessoais que são fontes de poder, e os resultados dos atos de poder.

O item 3.3 aborda os fundamentos de cultura organizacional envolvendo: diversos conceitos de cultura organizacional; os tipos de cultura organizacional e suas variáveis; os impactos da cultura no desempenho e na satisfação dos funcionários e as diferenças nas culturas nacionais.

A gestão estratégica de pessoas envolve o item 3.4, considerando: a estratégia e a gestão de pessoas; a evolução das práticas e da gestão de pessoas; o fluxo dinâmico de planejamento estratégico de RH; a integração da estratégia de RH na estratégia da empresa; a concepção tradicional X a concepção transformada de modelos de gestão de pessoas; as competências dos profissionais de RH; as escolas de estratégia, além dos tipos de estratégias e agentes e liderança. 
O penúltimo item é o bem-estar organizacional (BEO) e qualidade de vida no trabalho (QVT), onde são apresentados os fundamentos do bem-estar e o BEO; a evolução do conceito de QVT e suas características; os diversos modelos de QVT e seus indicadores; as variáveis qualitativas sobre o conceito de BEO; satisfação no trabalho; o triângulo do BEO e suas variáveis.

Por fim, abordam-se as relações de trabalho com os significados do trabalho ao longo da história; as mudanças no sistema brasileiro de relações de trabalho e as relações de trabalho e a internacionalização.

\subsection{Líder e Liderança}

Neste item são abordadas as diferentes concepções de líder e liderança no decorrer da história humana até os dias atuais e suas diversas características.

Primeiramente é relevante entender o conceito e o uso da liderança. DuBrin (1998, p. 2) afirma que o uso e conceito da liderança no século XX não foram uniformes, destacando-se os seguintes aspectos:

\footnotetext{
Aproximadamente 30.000 artigos de pesquisas, artigos de revistas e livros foram escritos sobre o tema liderança até agora, no século XX. Consequentemente, a liderança foi definida de muitas maneiras. Diversas outras definições representativas da liderança são apresentadas como:

- a influência interpessoal direcionada pela comunicação, para a realização de objetivos;

- o incremento influente sobre a conformidade mecânica com instruções e ordens;

- um ato que faça com que outros ajam ou respondam em um sentido compartilhado;

- a arte de influenciar pessoas pela persuasão ou pelo exemplo para que sigam uma linha de ação;

- a principal força dinâmica que motiva e coordena a organização para a realização de seus objetivos. ${ }^{2}$ (tradução do pesquisador)
}

O dicionário Michaelis (2007) afirma que líder é "1. Chefe, guia. 2. Tipo representativo de um grupo. 3. Chefe de um partido político.” Em uma visão mais ampla o dicionário Infopédia (2007) define líder como "1. chefe; orientador; pessoa que chefia uma empresa, uma corrente de opinião ou um grupo; 2. representante de uma bancada parlamentar;

\footnotetext{
${ }^{2}$ About 30.000 research articles, magazine articles, and books have been written about leadership so far this century. As a consequence, leadership has been defined in many ways. Several other representative definitions of leadership are as follows:

- Interpersonal influence directed through communication, toward goal attainment;

- The influential increment over and above mechanical compliance with directions and orders;

- An act that causes others to act or respond in a shared direction;

- The art of influencing people by persuasion or example to follow a line of action;
} 
3. Desporto: equipe ou atleta que ocupa o primeiro lugar em qualquer competição desportiva; (Do ing. leader, chefe)". A Liderança, dessa forma, é entendida como uma função do líder, ou seja, é o desempenho do líder, chefia ou orientação à função de liderar.

Liderar origina-se do inglês, to lead, cujo significado estabelece, "conduzir, dirigir, guiar, comandar, persuadir, encaminhar, encabeçar, capitanear, atravessar". Os registros datam sua origem de 825 d.C. Porém, há uma correlação entre os diversos conceitos de liderança com a palavra procedente do latim, ducere, cujo significado é conduzir, influenciando as derivações de to lead. Em 1.300 d.C., documentou-se leader, "condutor, guiador, capitaneador", como sendo aquele que exerce a função de conduzir e guiar. Surge na mesma época o substantivo de to lead, traduzido por "ação de conduzir". Já em 1.834, emerge a palavra Leadership significando "dignidade, função ou posição de guia, de condutor, de chefe". A língua portuguesa incorpora o vocábulo lead e seus derivados, na segunda metade do século XIX (ENCICLOPÉDIA MIRADOR INTERNACIONAL, 1989, p. 6.790).

Destacam-se algumas questões importantes: Todo gerente é um líder? Todo líder é um gerente? Cada gerente ou supervisor possui seu estilo de liderança, afinal, cada pessoa apresenta comportamentos que os diferem dos demais, surgindo assim os diversos tipos de liderança por eles utilizados.

Segundo Maximiano (2002, p. 47-48), os gerentes "são os agentes ou protagonistas do processo administrativo." O papel desempenhado por eles varia de uma organização para outra, com delegação ou não de responsabilidades, tarefas, funções, decisões, etc. No século $\mathrm{XX}$ diversos pesquisadores estudaram os papéis dos gerentes nas organizações. Pode-se citar de acordo com Maximiano (2002): a) Henri Fayol (1916), com o processo administrativo; b) Chester Barnard (1938), com as funções do executivo; c) Herbert Simon (1960), com o processo decisório; d) Henry Mintzberg (1973), com os papéis dos gerentes; e) Rosemary Stewart (1982), com o processo decisório; f) Fred Luthans (1988), com o desempenho dos gerentes; e g) Andrew Grove, (1983) com os princípios de administração de alta performance. O quadro 3 apresenta uma síntese dos principais papéis administrativos dos gestores.

- $\quad$ The principal dynamic force that motivates and coordinates the organization in the accomplishment of its objectives. 
Quadro 3 - Os Papéis administrativos

\begin{tabular}{|c|c|c|}
\hline \\
\hline Tipos de Papéis & Descrição & Atividades identificáveis \\
\hline \multicolumn{3}{|c|}{ Interpessoal } \\
\hline Chefe & $\begin{array}{l}\text { Desempenha tarefas de rotina de natureza } \\
\text { legal ou social. }\end{array}$ & $\begin{array}{l}\text { Cerimoniais, status, funções públicas, } \\
\text { legais ou sociais. }\end{array}$ \\
\hline Líder & $\begin{array}{l}\text { Responde pela motivação e ativação dos } \\
\text { subordinados, pelo suporte administrativo, } \\
\text { pelo tratamento de pessoal. }\end{array}$ & $\begin{array}{l}\text { Interação direta com os subordinados em } \\
\text { todas as atividades. }\end{array}$ \\
\hline Ligação & $\begin{array}{l}\text { Mantém desenvolvida a rede de contatos e } \\
\text { informantes e provê favores e informações. }\end{array}$ & $\begin{array}{l}\text { Validação de correspondências e } \\
\text { contatos externos importantes. }\end{array}$ \\
\hline \multicolumn{3}{|c|}{ Informacional } \\
\hline Monitor & $\begin{array}{l}\text { Procura e recebe ampla variedade de } \\
\text { informações especiais para desenvolver um } \\
\text { entendimento completo da organização e do } \\
\text { ambiente. }\end{array}$ & $\begin{array}{l}\text { Estabelecimento de todas as } \\
\text { correspondências e contatos relacionados } \\
\text { com as informações básicas recebidas. }\end{array}$ \\
\hline Disseminador & $\begin{array}{l}\text { Transmite informações recebidas aos } \\
\text { membros da organização (algumas } \\
\text { informações são factuais, outras exigem } \\
\text { interpretação e consolidação). }\end{array}$ & $\begin{array}{l}\text { Despacho de correspondência na } \\
\text { organização com os propósitos } \\
\text { informativos e manutenção de contatos } \\
\text { verbais com os subordinados. }\end{array}$ \\
\hline Interlocutor & $\begin{array}{l}\text { Transmite para fora as informações sobre } \\
\text { planos, políticas, ações, resultados etc.; } \\
\text { serve como especialista nas associações } \\
\text { organizacionais. }\end{array}$ & $\begin{array}{l}\text { Reuniões de diretoria, manuseio de } \\
\text { correspondência e contatos envolvendo } \\
\text { troca de informações externas. }\end{array}$ \\
\hline \multicolumn{3}{|c|}{ Decisorial } \\
\hline Empreendedor & $\begin{array}{l}\text { Pesquisa a organização e o seu ambiente } \\
\text { para oportunidades e inicia "projetos de } \\
\text { melhoria". }\end{array}$ & $\begin{array}{l}\text { Implementação de estratégias e sessões } \\
\text { de revisão envolvendo melhorias. }\end{array}$ \\
\hline $\begin{array}{l}\text { Solucionador de } \\
\text { Conflitos }\end{array}$ & $\begin{array}{l}\text { Toma as ações corretivas quando a } \\
\text { organização enfrenta perturbações } \\
\text { inesperadas. }\end{array}$ & $\begin{array}{l}\text { Implementação de estratégia e sessões } \\
\text { para resolver perturbações e crises. }\end{array}$ \\
\hline $\begin{array}{l}\text { Alocador de } \\
\text { recursos }\end{array}$ & $\begin{array}{l}\text { Responde pela alocação dos recursos } \\
\text { organizacionais de todos os tipos; toma e } \\
\text { aprova todas as decisões importantes. }\end{array}$ & $\begin{array}{l}\text { Programação, requerimentos de } \\
\text { autorização; qualquer atividade } \\
\text { envolvendo orçamento e a programação } \\
\text { de trabalho dos subordinados. }\end{array}$ \\
\hline Negociador & $\begin{array}{l}\text { Representa a organização em negociações } \\
\text { importantes e significativas. }\end{array}$ & Atividades de negociação. \\
\hline
\end{tabular}

Fonte: Silva (2002, p. 18). Transcrição integral.

Embora reconhecendo que os estudos sobre o papel dos dirigentes podem remontar às eras antiga e medieval, a maioria dos autores focalizou seus estudos na função dos gerentes ao longo do século XX. Entre eles destacam-se Henri Fayol, Chester Barnard, Robert L. Katz, Herbert Simon, Peter Drucker e Henry Mintzberg, cujas contribuições são reconhecidas e reproduzidas na academia e na esfera organizacional.

Atualmente entende-se que o gerente trabalha em uma organização com a função de planejar, organizar, dirigir e controlar os recursos da organização, visando atingir os objetivos desta. A tomada de decisão é uma das atividades essenciais no contexto gerencial, pois tudo o que o gerente vier a realizar recairá sobre qual o melhor caminho a seguir, portanto, eles necessitam de determinadas aptidões e competências para obter êxito na função de gerenciar. O quadro 4 apresenta as principais abordagens das funções dos gerentes e suas características. 
Quadro 4 - Abordagens das funções dos gerentes e suas características

\begin{tabular}{|c|c|}
\hline AUTOR & CARACTERÍSTICAS \\
\hline $\begin{array}{l}\text { Fayol: } \\
\text { Autoridade e } \\
\text { disciplina }\end{array}$ & $\begin{array}{l}\text { O funcionamento das organizações baseia-se numa estrutura de regras e princípios legais e } \\
\text { racionais. Aos dirigentes cabem as atividades relacionadas com a definição de metas e } \\
\text { diretrizes organizacionais, com a divisão de atividades entre seus integrantes e com o } \\
\text { controle das ações realizadas por seus subordinados. }\end{array}$ \\
\hline $\begin{array}{l}\text { Barnard: } \\
\text { Cooperação e } \\
\text { benefícios. }\end{array}$ & $\begin{array}{l}\text { Cabe aos executivos traçar objetivos e diretrizes, e posteriormente, doutrinar os membros } \\
\text { da organização para alinhá-los às definições empresariais, garantindo, assim, a coesão } \\
\text { organizacional. }\end{array}$ \\
\hline $\begin{array}{l}\text { Katz: } \\
\text { Habilidades e } \\
\text { competências }\end{array}$ & $\begin{array}{l}\text { Abordou a questão das habilidades e competências relacionadas com as funções gerenciais } \\
\text { e as dividiu em três categorias: Habilidade Técnica estaria associada a atividades } \\
\text { especificas da área do gestor e a Habilidade Humana, a capacidade de gerir as pessoas. Já a } \\
\text { Habilidade Conceitual deveria refletir a capacidade do gerente de atuar estrategicamente, } \\
\text { pela análise da complexa realidade da organização. }\end{array}$ \\
\hline $\begin{array}{l}\text { Simon: } \\
\text { Decisões em } \\
\text { três estágios }\end{array}$ & $\begin{array}{l}\text { A tomada de decisão passa por três estágios distintos: a análise do problema, a criação de } \\
\text { alternativas de solução e a escolha final. Diferencia o modelo de homem econômico, que } \\
\text { procura soluções para maximizar ganhos, do modelo de homem administrativo, que visa } \\
\text { soluções satisfatórias para os problemas identificados. Afirma também que os gerentes } \\
\text { enfrentam dois tipos de decisões: as programadas e as não-programadas. Estas exigiriam } \\
\text { dos gerentes capacidade de julgamento, intuição e criatividade. }\end{array}$ \\
\hline $\begin{array}{l}\text { Drucker: } \\
\text { Administração e } \\
\text { desempenho }\end{array}$ & $\begin{array}{l}\text { O que distingue o trabalho de um administrador é a responsabilidade da contribuição para } \\
\text { o desempenho da organização. Existem cinco operações principais no trabalho do } \\
\text { administrador: Fixação de objetivos; organização; motivação e comunicação; avaliação e } \\
\text { desenvolvimento de pessoas. }\end{array}$ \\
\hline $\begin{array}{l}\text { Mintzberg: } \\
\text { Liderança e } \\
\text { iniciativa }\end{array}$ & $\begin{array}{l}\text { As atividades dos gerentes estão associadas à gestão de relações interpessoais, informações } \\
\text { e decisões. O gerente como gestor de relações interpessoais tornar-se-ia um representante } \\
\text { da organização perante os ambientes interno e externo; nas funções de informações } \\
\text { assumiria a responsabilidade pelo monitoramento e pela disseminação das informações } \\
\text { empresariais, e por fim em relação ao papel decisório, deveria agir como empreendedor e } \\
\text { agente de mudanças, enfrentando conflitos e administrando o processo de decisão. }\end{array}$ \\
\hline
\end{tabular}

Fonte: Nogueira (2007, p. 86-90). Transcrição integral.

Maximiano (2002, p. 303-304) compara as características da autoridade formal do gerente e da liderança. Relata que a liderança é diferente da autoridade formal, que é uma das bases das organizações e um atributo dos cargos gerenciais. Os gerentes ocupam cargos e têm o direito de tomar decisões, durante um determinado período que ocupar o cargo, segundo algum critério de divisão do trabalho. Portanto, existe a autoridade dotada do poder de comando e os seguidores obedecem à lei incorporada na figura de autoridade, não à pessoa que ocupa o cargo.

Por outro lado, a liderança fundamenta-se na crença dos seguidores a respeito das qualidades do líder e de seu interesse em segui-lo. Os seguidores obedecem ao líder e à missão que ele representa, sendo instrumento para resolver problemas da organização. A liderança é limitada ao grupo que acredita ou precisa do líder, ou seja, define a área de influência. A liderança é produto de inúmeros fatores como características pessoais dos liderados, características da tarefa ou missão, características pessoais do líder e do contexto organizacional e social da liderança. 
Na visão de Maximiano (2002, p. 303), liderança é “o processo de conduzir as ações ou influenciar o comportamento e a mentalidade de outras pessoas, ou é a realização de metas por meio da direção de colaboradores".

Quadro 5 - Liderança versus Administração/Gestão

\begin{tabular}{|l|l|l|}
\hline \multicolumn{1}{|c|}{ Variável } & \multicolumn{1}{|c|}{ Liderança } & \multicolumn{1}{c|}{ Administração/Gestão } \\
\hline Criando uma agenda & $\begin{array}{l}\text { - estabelece a direção: desenvolve uma } \\
\text { visão e as estratégias necessárias para } \\
\text { sua realização. }\end{array}$ & $\begin{array}{l}\text { - plantas e orçamentos: estabelece } \\
\text { etapas detalhadas e cronogramas para } \\
\text { conseguir resultados necessários; aloca } \\
\text { recursos necessários. }\end{array}$ \\
\hline $\begin{array}{l}\text { Desenvolvendo uma rede } \\
\text { para conseguir a agenda }\end{array}$ & $\begin{array}{l}\text { - envolve alinhar pessoas: comunica o } \\
\text { sentido das comunicações e das ações } \\
\text { a todos ou aqueles cuja cooperação } \\
\text { pode ser necessária para ajudar a criar } \\
\text { as equipes e os grupos que } \\
\text { compreendem a visão e as estratégias, } \\
\text { e aceita sua validade. }\end{array}$ & $\begin{array}{l}\text { - organização e staffs: estabelece a } \\
\text { estrutura para conseguir as plantas; } \\
\text { equipes de funcionários; } \\
\text { responsabilidade e autoridade dos } \\
\text { delegados para a execução; desenvolve } \\
\text { políticas e procedimentos para guiar } \\
\text { pessoas; cria sistemas de monitoração. }\end{array}$ \\
\hline Execução & $\begin{array}{l}\text { - motivação e inspiração: energiza } \\
\text { pessoas para superar barreiras políticas } \\
\text { principais, burocráticas, e de recurso } \\
\text { para mudar por necessidades básicas } \\
\text { do ser humano de satisfação. }\end{array}$ & $\begin{array}{l}\text { - controles e soluções de problemas; os } \\
\text { monitores resultam de encontro às } \\
\text { plantas, e então às plantas e organizam } \\
\text { para fechar a abertura. }\end{array}$ \\
\hline Resultados & $\begin{array}{l}\text { - produz a mudança, frequentemente a } \\
\text { um grau dramático: tem o potencial de } \\
\text { produzir a mudança extremamente útil, } \\
\text { tal como os produtos novos desejados } \\
\text { por gerentes. }\end{array}$ & $\begin{array}{l}\text { - produz um grau de previsão e de } \\
\text { ordem: tem o potencial de produzir } \\
\text { consistentemente os resultados chaves } \\
\text { esperados por várias partes } \\
\text { interessadas (tais como fins do prazo } \\
\text { da reunião para clientes e dividendos } \\
\text { para pagar aos acionistas). }\end{array}$ \\
\hline
\end{tabular}

Fonte: DuBrin (1998, p. 4) Tradução livre do pesquisador.

Os gestores enfatizam a estrutura organizacional, os mecanismos de controle, a eficiência, as despesas, as técnicas empresariais, a mensuração dos resultados, a rapidez, os resultados, os métodos, as práticas, entre outras características. A função de liderar é mais abrangente, pois a ênfase é nas pessoas, na autonomia, no comprometimento dos colaboradores, no investimento, no fazer a coisa certa, nos propósitos e princípios, na eficácia, etc.

Dessa forma, entende-se que a liderança é diferente do gerenciamento. $O$ gerenciamento está relacionado a lidar com a complexidade organizacional, enquanto a liderança está relacionada a lidar com desafios.

Bowditch e Buono (2002, p. 118) afirmam que “[...] a liderança pode ser considerada como um processo de influência, geralmente uma pessoa, através do qual um indivíduo ou grupo é orientado para o estabelecimento e atingimento de metas". Portanto, a liderança é uma relação entre pessoas através da influência e do poder e são distribuídos de maneira desigual 
em uma base legítima (contratual ou consensual). A liderança não ocorre no isolamento, ou seja, não há líderes sem seguidores.

Os mesmos autores destacam que a eficácia da liderança é determinada pelo ponto até o qual os líderes possam adaptar seus padrões e comportamentos para se ajustar às necessidades e requisitos de uma certa situação. Dessa forma, um gerente é provido de poder legítimo para dirigir as atividades relacionadas ao trabalho. Sendo assim, nem todo gerente é um líder, mas há mais na gerência do que a simples liderança, pois envolve outros papéis gerenciais como planejar, organizar, dirigir e controlar todos os recursos disponíveis da organização.

Para DuBrin (1998, p. 24-49), as características associadas com liderança podem ser classificadas em três categorias, como traços de personalidade, motivações e fatores cognitivos dos líderes:

a) Traços de personalidade para efetividade dos líderes: observações e pesquisas de especialistas indicam que os líderes têm certos traços de personalidade. Estas características contribuem para a efetividade da liderança em muitas situações: 1-) traços gerais da personalidade; 2-) auto-confiança; 3-) confiança; 4-) personalidade dominante; 4-) extroversão; 5-) assertividade; 6-) estabilidade emocional; 7-) entusiasmo; 8-) senso de humor; 9-) empatia; 10-) tolerância elevada para a frustração; 11-) auto-consciência e autoobjetivos; 12-) tarefa relacionada com traços de personalidade; 13-) iniciativa; 14-) sensibilidade a outras pessoas e empatia; 15-) flexibilidade e adaptabilidade; 16-) locus interno de controle; 17-) coragem; 18-) resiliência.

b) As motivações envolvem fatores como: 1-) motivo do poder; 2-) motivo da personalidade de poder; 3-) motivo de socialização de poder; 4-) motivação de movimentação e de realização; 5-) ética forte do trabalho; 6-) tenacidade;

c) Fatores cognitivos e liderança: 1-) habilidade mental e a teoria cognitiva do recurso; 2-) conhecimento do negócio; 3-) criatividade; 4-) introspecção em pessoas e em situações; 5) abertura à experiências.

De acordo com Montana e Charnov (1998), Soto (2002), Polo, Weber e Maximo (2004), um líder formal é alguém que foi oficialmente investido de autoridade e poder organizacional e geralmente recebe o título de gerente, diretor ou supervisor. A quantidade de poder é teoricamente determinada pela posição ocupada dentro da organização. As políticas de promoção organizacional são realizadas para garantir que as pessoas com habilidades técnicas e de liderança ocupem posições de poder. Por outro lado, um líder informal não terá o 
mesmo título de liderança oficial, mas poderá exercer um tipo de poder, pelo mérito de um atributo pessoal ou desempenho superior influenciando os outros e exercendo função de liderança.

Os três estilos básicos de liderança formal causam impacto nos climas sociais das organizações. São eles: autocrático, liberal e democrático (BERGAMINI, 1994, 2002). Os resultados adotando a liderança autocrática vão desde tensão, frustração e agressividade, até a perda da produtividade. A liderança liberal propicia individualismo, desagregação do grupo, insatisfação, agressividade, entre outros resultados. Já a liderança democrática traduz em qualidade, clima de satisfação, integração grupal, de responsabilidade e de comprometimento das pessoas (ROBBINS, 2005; SOTO, 2002).

O quadro 6 sintetiza as principais características dos estilos de comportamento dos líderes: autoritário, democrático e liberal.

\begin{tabular}{|l|l|l|}
\hline \multicolumn{1}{|c|}{ Quadro 6 - Estilos de Comportamento dos Líderes } \\
\hline \multicolumn{1}{|c|}{ AUTORITÁTIO } & \multicolumn{1}{|c|}{ DEMOCRÁTICO } & \multicolumn{1}{c|}{ LIBERAL } \\
\hline O líder determina as tarefas & $\begin{array}{l}\text { Os membros são livres para } \\
\text { trabalhar, podem escolher e a } \\
\text { divisão das tarefas é deixada ao } \\
\text { grupo. }\end{array}$ & $\begin{array}{l}\text { O líder não participa da atribuição } \\
\text { de tarefas. }\end{array}$ \\
\hline $\begin{array}{l}\text { As execuções das atividades são } \\
\text { ditadas pela autoridade, um de cada } \\
\text { vez, de modo que futuros passos } \\
\text { ficam, em grande parte, incertos. }\end{array}$ & $\begin{array}{l}\text { A atividade é discutida. Os passos } \\
\text { gerais para as metas do grupo são } \\
\text { esquematizados e, quando o } \\
\text { aconselhamento técnico é } \\
\text { necessário, o líder sugere dois ou } \\
\text { mais procedimentos alternativos, } \\
\text { entre os quais o grupo pode } \\
\text { escolher. }\end{array}$ & $\begin{array}{l}\text { Subsídios são oferecidos pelo líder, } \\
\text { que deixa claro que ele fornecerá } \\
\text { informações quando solicitado. } \\
\text { Fora isso, o líder não toma parte na } \\
\text { discussão. }\end{array}$ \\
\hline $\begin{array}{l}\text { Pessoal nos elogios e críticas do } \\
\text { trabalho de cada um; permanece } \\
\text { distante da participação ativa. }\end{array}$ & $\begin{array}{l}\text { O líder é “objetivo" ou “orientado } \\
\text { aos fatos" em seus elogios e } \\
\text { críticas. }\end{array}$ & $\begin{array}{l}\text { Evita fazer comentários sobre as } \\
\text { atividades dos membros, a não ser } \\
\text { quando interrogado; não tenta } \\
\text { avaliar. }\end{array}$ \\
\hline
\end{tabular}

Fonte: Bergamini (1994, 2002). Adaptado parcialmente.

Observa-se no quadro 6 que, quanto mais concentrada a autoridade do líder, mais é autocrático seu comportamento e quanto mais decisões forem influenciadas pelos funcionários da organização, mais democrático é seu comportamento. Quando o líder transfere sua autoridade para os liderados, descentralizando o poder de tomar decisões, seu comportamento é mais liberal.

Segundo Bowditch e Buono (2002), Soto (2002), Robbins (2005), Liu, Lepak, Takeuch e Sims Jr (2003) e Covey (2005), a liderança tem sido entendida de diversas formas nos últimos séculos, conforme síntese apresentada no quadro 7. 
Quadro 7 - Evolução das Teorias ou Abordagens de Liderança

\begin{tabular}{|c|c|c|}
\hline Época/Autores & $\begin{array}{c}\text { Teoria ou } \\
\text { Abordagem de } \\
\text { Liderança } \\
\end{array}$ & Características/Conceitos de Liderança \\
\hline Platão & Filosofia & Líderes eficazes são reis da filosofia \\
\hline Jesus de Nazaré (Século 0) & Liderança Carismática & Lideres são éticos, tem comprometimento e visão \\
\hline Maquiavel (Século XV) & Poder e Manipulação & $\begin{array}{l}\text { Líderes eficazes são "exercedores" de poder, indivíduos } \\
\text { que empregam manipulação, exploração e desonestidade } \\
\text { para realizar seus próprios fins. }\end{array}$ \\
\hline Weber (Século XIX) & Poder e Autoridade & $\begin{array}{l}\text { Líder em organizações burocráticas (militares e } \\
\text { religiosas) relações de poder e autoridade. }\end{array}$ \\
\hline $\begin{array}{l}\text { Antes de } 1900 \\
\text { Dowd (1936) }\end{array}$ & $\begin{array}{l}\text { Teorias do Grande } \\
\text { Homem }\end{array}$ & $\begin{array}{l}\text { As instituições históricas e sociais são moldadas pela } \\
\text { liderança de grandes homens e mulheres (graus de } \\
\text { inteligência, energia e força moral) }\end{array}$ \\
\hline Antes de 1918 & Teoria Genética & $\begin{array}{l}\text { As características dos líderes são herdadas, dos pais para } \\
\text { os filhos. }\end{array}$ \\
\hline Taylor e Fayol & $\begin{array}{l}\text { Abordagem da } \\
\text { Racionalidade } \\
\text { Escola Clássica da } \\
\text { Administração } \\
\end{array}$ & $\begin{array}{l}\text { Líderes eficazes vêem a administração como uma ciência. } \\
\text { Autoridade Formal. Exerce as funções de controle, } \\
\text { supervisão. Abordagem mecanística, intervencionista e } \\
\text { determinística. }\end{array}$ \\
\hline Mayo, Barnard, Lewin & $\begin{array}{l}\text { Escola das Relações } \\
\text { Humanas }\end{array}$ & $\begin{array}{l}\text { Interações socioemocionais. Estímulo às relações } \\
\text { informais, à cooperação entre grupos. Líderes informais. }\end{array}$ \\
\hline Weber, Hall, Merton & Escola da Burocracia & $\begin{array}{l}\text { Mecanística, impessoal, controle, razão instrumental, } \\
\text { ascende ao cargo via mérito e competência técnica. }\end{array}$ \\
\hline Etzioni, Blau e Scott & Escola Estruturalista & $\begin{array}{l}\text { O exercício da Liderança vem do conhecimento técnico, } \\
\text { da identificação com os objetivos. Líder com } \\
\text { características carismáticas para legitimar a autoridade. }\end{array}$ \\
\hline $\begin{array}{l}\text { Argyris }(1957,1964), \\
\text { Blake \& Mounton (1964), } \\
\text { Hersey \& Blanchard } \\
\text { (1972), Likert (1961), } \\
\text { Maslow (1965), McGregor } \\
(1960,1966)\end{array}$ & $\begin{array}{l}\text { Escola } \\
\text { Comportamental }\end{array}$ & $\begin{array}{l}\text { Delegar responsabilidade. Percepção da situação } \\
\text { influenciando a liderança. Teoria X e Y. Suprir as } \\
\text { necessidades dos indivíduos como agentes motivadores. } \\
\text { A liderança existe para modificar restrições } \\
\text { organizacionais, visando proporcionar liberdade para que } \\
\text { as pessoas realizem seu pleno potencial e contribuam } \\
\text { para a organização. }\end{array}$ \\
\hline $\begin{array}{l}\text { Von Bertalanffy, Katz e } \\
\text { Kahn }\end{array}$ & Teoria de Sistemas & $\begin{array}{l}\text { Varia o estilo de liderança conforme o nível hierárquico } \\
\text { que atua. Ênfase na análise ao ambiente. }\end{array}$ \\
\hline $\begin{array}{l}\text { Antes da Segunda Guerra } \\
\text { Mundial (anterior 1939) } \\
\text { Barnard (1926), Bingham } \\
\text { (1927), Kilbourne (1935), } \\
\text { Page (1935) }\end{array}$ & Teoria dos Traços & $\begin{array}{l}\text { Os líderes já nascem com as habilidades de liderança. O } \\
\text { líder é nato. O líder é dotado de traços e características } \\
\text { superiores que o diferenciam dos seguidores. }\end{array}$ \\
\hline Década de 1950 & $\begin{array}{l}\text { Abordagem } \\
\text { Comportamental }\end{array}$ & $\begin{array}{l}\text { Estilo ideal de liderança, que poderia ser } \\
\text { desenvolvido/aprendido }\end{array}$ \\
\hline $\begin{array}{l}\text { Bogardus (1918), Hocking } \\
\text { (1924), Person (1928), } \\
\text { Hersey \& Blanchard } \\
(1972)\end{array}$ & Teorias Situacionais & $\begin{array}{l}\text { A liderança é resultado de demandas situacionais. } \\
\text { Situação/contexto/meio definem o estilo ideal de } \\
\text { Liderança, que pode ser desenvolvido. }\end{array}$ \\
\hline $\begin{array}{l}\text { Barnard (1938), Bass } \\
\text { (1960), Brown (1936), } \\
\text { Case (1933), Lapiere } \\
\text { (1938), Murphy (1941) }\end{array}$ & $\begin{array}{l}\text { Teorias Pessoais- } \\
\text { Situacionais }\end{array}$ & $\begin{array}{l}\text { A liderança deveria incluir traços afetivos, intelectuais e } \\
\text { de ação, bem como as condições específicas em que a } \\
\text { pessoa opera. }\end{array}$ \\
\hline $\begin{array}{l}\text { Erikson (1964), Frank } \\
\text { (1939), Freud (1913, } \\
\text { 1922), Fromm (1941), } \\
\text { Levison (1970), Wolman } \\
\text { (1971) }\end{array}$ & Teorias Psicanalíticas & $\begin{array}{l}\text { O líder funciona como uma figura paterna: uma fonte de } \\
\text { amor ou medo. }\end{array}$ \\
\hline $\begin{array}{l}\text { Homans (1950), Kahn \& } \\
\text { Quimm (1970), Kerr \& }\end{array}$ & $\begin{array}{l}\text { Teoria do Papel do } \\
\text { Líder }\end{array}$ & $\begin{array}{l}\text { Características da pessoa e exigências da situação } \\
\text { interagem de modo a permitir que uma ou algumas }\end{array}$ \\
\hline
\end{tabular}




\begin{tabular}{|c|c|c|}
\hline $\begin{array}{l}\text { Jermier (1978), Mintzberg } \\
\text { (1973), Osborn \& Hunt } \\
(1975)\end{array}$ & & $\begin{array}{l}\text { pessoas surjam como líderes. Os líderes se comportam de } \\
\text { acordo com sua percepção do papel e das expectativas } \\
\text { dos outros. }\end{array}$ \\
\hline $\begin{array}{l}\text { Evans (1970), } \\
\text { Georgopoulos (1957), } \\
\text { House (1971, 1974) }\end{array}$ & $\begin{array}{l}\text { Teoria da Trajetória- } \\
\text { Meta }\end{array}$ & $\begin{array}{l}\text { Os líderes reforçam as mudanças dos seguidores ao } \\
\text { mostrar os comportamentos (trajetórias) que levam às } \\
\text { recompensas. Os fatores situacionais determinam o modo } \\
\text { como os líderes atingem esses propósitos de trajetória- } \\
\text { meta. }\end{array}$ \\
\hline $\begin{array}{l}\text { Fiedler (1967); Fiedler, } \\
\text { Chemers \& Mahar (1976) }\end{array}$ & $\begin{array}{l}\text { Teorias da } \\
\text { Contingência }\end{array}$ & $\begin{array}{l}\text { A eficácia de um líder voltado para tarefas ou relações } \\
\text { depende da situação. O treinamento ajuda o líder } \\
\text { identificar sua orientação para os aspectos favoráveis ou } \\
\text { desfavoráveis das situações. }\end{array}$ \\
\hline $\begin{array}{l}\text { Gardner (1995), J. Collins } \\
\text { (2001) }\end{array}$ & $\begin{array}{l}\text { Liderança Cognitiva: } \\
\text { o grande homem do } \\
\text { séc. XX }\end{array}$ & $\begin{array}{l}\text { Os líderes são pessoas que influenciam de modo } \\
\text { significativo os comportamentos, pensamentos e/ou } \\
\text { sentimentos de muitas pessoas. }\end{array}$ \\
\hline $\begin{array}{l}\text { Davis \& Luthans (1979), } \\
\text { Fiedler \& Leister (1977), } \\
\text { Fulk \& Wendler (1982), } \\
\text { Graen (1976), Greene } \\
\text { (1975), Yuki (1971) }\end{array}$ & $\begin{array}{l}\text { Teorias e modelos dos } \\
\text { processos interativos }\end{array}$ & $\begin{array}{l}\text { A liderança é um processo interativo com múltiplos } \\
\text { (vínculos, telas, vínculo duplo vertical, teorias de troca, } \\
\text { de comportamento de troca e de comunicação). }\end{array}$ \\
\hline $\begin{array}{l}\text { Coch \& French (1948), } \\
\text { Gardner (1990), Lewin } \\
\text { (1939), Vroom \& Yetton } \\
\text { (1974) }\end{array}$ & $\begin{array}{l}\text { Poder-Influência: } \\
\text { Liderança } \\
\text { Participativa, lógica } \\
\text { dedutiva }\end{array}$ & $\begin{array}{l}\text { O quanto o poder é detido e exercido pelo líder. Os } \\
\text { líderes assumem as diretivas e os subordinados são } \\
\text { seguidores passivos (Vroom \& Yetton) }\end{array}$ \\
\hline $\begin{array}{l}\text { Bryon \& Kelley (1978), } \\
\text { Katz \& Kahn (1966), Lord } \\
\text { (1976, 1985), Lord } \\
\text { (1978), Mitchell (1977), } \\
\text { Newell \& Simon (1972), } \\
\text { Weiss (1977) }\end{array}$ & $\begin{array}{l}\text { Atribuição, } \\
\text { processamento da } \\
\text { informação e sistemas } \\
\text { abertos }\end{array}$ & $\begin{array}{l}\text { A liderança é uma realidade construída socialmente. As } \\
\text { variáveis individuais, processuais, estruturais e } \\
\text { ambientais são fenômenos mutuamente causais. }\end{array}$ \\
\hline $\begin{array}{l}\text { Bass \& Bennis (1984, } \\
\text { 1992), Burns (1978), } \\
\text { Downton (1973), Fairholm } \\
\text { (1991), DePree (1992), } \\
\text { Tichy \& Devanna, } \\
\text { Renesch }\end{array}$ & $\begin{array}{l}\text { Integrativas: } \\
\text { transformacionais; } \\
\text { embasadas em valores }\end{array}$ & $\begin{array}{l}\text { Burns afirma que a liderança transformacional é um } \\
\text { processo em que os líderes e os seguidores se elevam } \\
\text { mutuamente a níveis mais altos de moralidade e } \\
\text { motivação. Os líderes transformam as organizações } \\
\text { alinhando os recursos. }\end{array}$ \\
\hline $\begin{array}{l}\text { House (1977), Kets se } \\
\text { Vries (1988), Maxwell } \\
\text { (1999), Weber (1947) }\end{array}$ & $\begin{array}{l}\text { Nova Liderança } \\
\text { Carismática }\end{array}$ & $\begin{array}{l}\text { Os líderes são detentores de qualidades excepcionais na } \\
\text { percepção dos subordinados. Explicações: a atribuição, } \\
\text { as observações objetivas, a teoria do autoconceito, a } \\
\text { psicanalítica e do contágio social. }\end{array}$ \\
\hline
\end{tabular}

Fonte: Bowditch e Buono (2002), Soto (2002), Robbins (2005), Liu, Lepak, Takeuch e Sims Jr (2003) e Covey (2005). Transcrição parcial e adaptação do pesquisador.

Os filósofos gregos também observaram como os líderes têm um papel na sociedade.

Para Platão, os líderes eficazes eram "reis da filosofia", ou seja, eram os detentores do conhecimento e capaz de sua disseminação.

A liderança carismática, analisada a partir da Bíblia sobre a vida e obra de Jesus de Nazaré, apresenta diversas características relevantes como a missão de vida, a visão, a ética, a comunicação, a coragem, o comprometimento com a causa, a sensibilidade, o discernimento e a educabilidade. Essas características foram observadas em diversas passagens entorno de Jesus com seus discípulos e demais seguidores (CURY, 1999). 
Maquiavel (1976, p. 35) relatava as dificuldades e obstáculos os quais o príncipe, que era o líder, poderia encontrar na sua trajetória: “deve-se considerar não haver coisa mais difícil para cuidar, nem duvidosa a conseguir, nem mais perigosa de manejar, que se tornar chefe e introduzir novas ordens".Ou seja, o líder tem responsabilidades e não são tarefas fáceis, pois está se relacionando com pessoas que têm expectativas, qualidades e limitações, além da resistência natural às mudanças e ao novo. $\mathrm{O}$ mesmo autor considerava que os líderes eram de direito e fato os "exercedores" de poder, manipulando pessoas e objetivando seus interesses.

De acordo com Montana e Charnov (1998, p. 225-226), uma das mais antigas explicações de liderança é a abordagem genética, a crença de que a habilidade de liderança é transmitida geneticamente, dos pais para os filhos, com o pressuposto de que o "líder é nato, não feito". Os reis acreditavam nessa premissa e no direito a uma posição de liderança chamada de direito divino dos reis (ou da realeza). Essa crença sobreviveu até a primeira guerra mundial quando muitos castelos Europeus foram destruídos e a força dos reis diminuiu. A teoria genética não pôde explicar porque muitos indivíduos chegaram a posições de liderança em organizações e em países sem serem de famílias reais.

A liderança é reconhecida como essencial a todo tipo de organização humana por muitos pesquisadores como Bennis (2001), Ulrich (1999) Ulrich; Zenger e Smallwood (2000), Goleman (2002), Bergamini (1994, 2002), porém, não obteve grande atenção dos primeiros estudiosos da administração. Inicialmente voltada para a tarefa, como visto nos trabalhos de Taylor e, posteriormente à estrutura organizacional, nos de Fayol, foi somente por volta da década de 1930, com o advento da Teoria das Relações Humanas, que a ciência administrativa passou a priorizar as pessoas e seus relacionamentos sociais, em detrimento de aspectos técnicos e formais das organizações.

$\mathrm{Na}$ Teoria Clássica, com Taylor, Fayol e seus seguidores, a liderança era considerada apenas sob o aspecto de autoridade formal, vinculada ao cargo de chefia e suas relações com os subordinados. A Teoria das Relações Humanas resgatou a existência e a influência das lideranças informais dentro dos grupos de trabalhadores, atuando paralelamente ao poder formal.

De acordo com Covey (2005), a revisão da bibliografia relativa a teorias da liderança no século XX observa cinco grandes abordagens, incluindo: os traços dos líderes, comportamento, influência-poder, situação e integração.

Segundo Bergamini (1994, 2002) e Bowditch e Buono (2002), a teoria dos traços ou características enfatizava, de forma especial, as qualidades pessoais do líder, partindo do 
pressuposto que o mesmo deveria possuir determinadas características de personalidade, facilitando assim, o desempenho de seu papel.

Bergamini (1994, 2002) e Vergara (2000) relatam que existem três grandes tipos de traços: primeiro, os fatores físicos, tais como altura, peso, físico, aparência e idade; segundo, os pesquisadores examinaram habilidades características, tais como inteligência, fluência verbal, escolaridade e conhecimento, e em terceiro, foram examinados uma ampla gama de aspectos de personalidade. Tais aspectos incluíram moderação, introversão, extroversão, dominância, ajustamento pessoal, autoconfiança, sensibilidade interpessoal e controle emocional.

A teoria dos traços predominou com êxito até a década de 1940, onde vários estudos foram realizados, obtendo inúmeros traços de personalidade considerados como características típicas de amostragem dos líderes eficazes.

Para Montana e Charnov (1998, p.226-7),

[...] a dificuldade final com esse tipo de abordagem para o entendimento da liderança é que, sendo uma teoria baseada na genética, ela não assume que as características são aprendidas. Porém pode ser este o caso: muitas características de liderança, como as habilidades de comunicação e tomada de decisão, podem ser aprendidas.

Diversos estudos foram realizados e se reconheceu que os traços não serviam para definir com precisão suficiente a natureza da liderança, já que esta parecia ser afetada por fatores externos aos líderes em cada situação. Os pesquisadores então, começaram a procurar nos comportamentos em grupo uma resposta para a verdadeira definição de liderança.

A teoria dos traços voltou a ser estudada e utilizada a partir da década de 1980, em especial nas pesquisas que estudavam traços relacionados à eficácia e ao sucesso em situações organizacionais específicas. Neste período, destacaram -se, também, os estudos sobre líderes corporativos fortes e sua capacidade de desenvolver um senso compartilhado de valores e da missão entre seus subordinados. À medida que se evidenciava a dificuldade em isolar traços ou características que distinguissem os líderes eficazes, os pesquisadores passaram a tentar identificar os comportamentos que pudessem determinar o seu sucesso.

O movimento das relações humanas proporcionou o surgimento de análises para um melhor entendimento do comportamento dos indivíduos, pois esse movimento visava mais as pessoas do que a tarefa em si, buscando uma compreensão individual do trabalhador para assim obter uma melhor produtividade. 
Na década de 1950 surgiu a abordagem comportamental, em que a formação de líderes se tornou uma atividade importante, pois através dela poder-se-iam modificar e adaptar comportamentos. Ela enfatiza que a liderança pode ser aprendida através de técnicas de desenvolvimento pessoal, mudando a afirmação anterior que dizia que a liderança era, somente, herdada (ROBBINS, 2005; SOTO, 2002; CONGER, FULMER, 2003).

Segundo Montana e Charnov (1998, p. 227), "o foco dessa abordagem ao comportamento de liderança proporcionou uma percepção verdadeira das origens e eficácia da liderança, mas sua procura pelo melhor estilo de liderança é um ponto fraco". Para evidenciar os tipos de comportamento dos líderes e a eficácia de sua forma de liderar, diversas pesquisas foram realizadas, destacando-se dois grupos distintos dentro dessa abordagem: a ênfase nas pessoas e nas tarefas, "isso significa que parte das atividades do líder está ligada a coisas, enquanto que a outra parte envolve pessoas" (BERGAMINI, 1994, p. 39).

Likert (1975) é tido como um dos expoentes da teoria Comportamental, pois considera a administração como um processo relativo. Na concepção dele, a administração possui feições diferentes, portanto nunca é e nem será igual em todas as organizações. Assim sendo, não existem princípios universais válidos para todas as circunstâncias e oportunidades.

O modelo desse autor é composto de quatro alternativas de sistemas administrativos, conhecidos como: autoritário-coercitivo, autoritário-benevolente, consultivo e participativo. Eles são avaliados em função de certas variáveis comparativas, como o processo de tomada de decisões, as comunicações, os sistemas de interação e influenciação entre os participantes, a fixação de objetivos, o controle organizacional sobre o desempenho, o relacionamento interpessoal, os sistemas de recompensas e de punições etc., formando um perfil organizacional que pode caracterizar cada empresa, de acordo com o que afirmam Alberto, Stefano e Neves (2002), Stefano e Gomes Filho (2003, 2004a).

Quadro 8 - Os Quatro Sistemas Administrativos de Likert e suas Variáveis Comparativas

\begin{tabular}{|l|l|l|l|l|}
\hline $\begin{array}{c}\text { Variáveis } \\
\text { Comparativas }\end{array}$ & \multicolumn{1}{|c|}{$\begin{array}{c}\text { Sistema 1 } \\
\text { Autoritário } \\
\text { Coercitivo }\end{array}$} & $\begin{array}{c}\text { Sistema 2 } \\
\text { Autoritário } \\
\text { Benevolente }\end{array}$ & $\begin{array}{l}\text { Sistema 3 } \\
\text { Consultivo }\end{array}$ & $\begin{array}{c}\text { Sistema 4 } \\
\text { Participativo }\end{array}$ \\
\hline $\begin{array}{l}\text { Processo } \\
\text { Decisorial }\end{array}$ & $\begin{array}{l}\text { Totalmente } \\
\text { centralizado na cúpula } \\
\text { da organização que } \\
\text { monopoliza as } \\
\text { decisões. }\end{array}$ & $\begin{array}{l}\text { Centralizado na } \\
\text { cúpula, permitindo } \\
\text { pequena delegação de } \\
\text { decisões simples e } \\
\text { rotineiras. }\end{array}$ & $\begin{array}{l}\text { Consulta aos níveis } \\
\text { inferiores, permitindo } \\
\text { delegação e } \\
\text { participação das } \\
\text { pessoas. }\end{array}$ & $\begin{array}{l}\text { Totalmente } \\
\text { delegado e } \\
\text { descentralizado. } \\
\text { Cúpula define } \\
\text { políticas e controla } \\
\text { resultados. }\end{array}$ \\
\hline $\begin{array}{l}\text { Sistema de } \\
\text { Comunicações }\end{array}$ & $\begin{array}{l}\text { Bastante Precário. } \\
\text { Somente } \\
\text { comunicações }\end{array}$ & $\begin{array}{l}\text { Relativamente } \\
\text { precário, } \\
\text { verticais, }\end{array}$ & $\begin{array}{l}\text { O fluxo de } \\
\text { comunicações } \\
\text { verticais (ascendentes } \\
\text { comunicações }\end{array}$ & $\begin{array}{l}\text { As comunicações } \\
\text { são vitais para o } \\
\text { sucesso da empresa. } \\
\text { A informação é }\end{array}$ \\
\hline
\end{tabular}




\begin{tabular}{|c|c|c|c|c|}
\hline & $\begin{array}{l}\text { descendentes, } \\
\text { carregando ordens. }\end{array}$ & $\begin{array}{l}\text { verticais descendentes } \\
\text { sobre as ascendentes. }\end{array}$ & $\begin{array}{l}\text { horizontais é } \\
\text { facilitado. }\end{array}$ & $\begin{array}{l}\text { totalmente } \\
\text { compartilhada. }\end{array}$ \\
\hline $\begin{array}{l}\text { Relações } \\
\text { Interpessoais }\end{array}$ & $\begin{array}{l}\text { Contatos entre pessoa } \\
\text { provocam } \\
\text { desconfiança. A } \\
\text { organização formal é } \\
\text { vedada e considerada } \\
\text { prejudicial. Os cargos } \\
\text { confinam as pessoas. }\end{array}$ & $\begin{array}{l}\text { São toleradas com } \\
\text { alguma } \\
\text { condescendência. A } \\
\text { organização informal } \\
\text { é incipiente e } \\
\text { considerada como } \\
\text { uma ameaça à } \\
\text { empresa. }\end{array}$ & $\begin{array}{l}\text { Relativa confiança é } \\
\text { depositada nas } \\
\text { pessoas. A empresa } \\
\text { incentiva à } \\
\text { organização informal. } \\
\text { Trabalho em equipe } \\
\text { ou em grupos } \\
\text { esporádicos. }\end{array}$ & $\begin{array}{l}\text { Trabalho realizado } \\
\text { em equipes. } \\
\text { Formação de grupos } \\
\text { informais é } \\
\text { importante. } \\
\text { Confiança mútua, } \\
\text { participação e } \\
\text { envolvimento grupal } \\
\text { intenso. }\end{array}$ \\
\hline $\begin{array}{l}\text { Sistema de } \\
\text { Recompensas e } \\
\text { Punições }\end{array}$ & $\begin{array}{l}\text { Ênfase nas punições e } \\
\text { medidas disciplinares. } \\
\text { Obediência estrita aos } \\
\text { regulamentos internos. } \\
\text { Raras recompensas } \\
\text { materiais. }\end{array}$ & $\begin{array}{l}\text { Ênfase nas punições e } \\
\text { medidas disciplinares } \\
\text { com menor } \\
\text { arbitrariedade. } \\
\text { Recompensas salariais } \\
\text { mais frequientes. } \\
\text { Recompensas sociais } \\
\text { raras. }\end{array}$ & $\begin{array}{l}\text { Ênfase nas } \\
\text { recompensas materiais } \\
\text { (principalmente } \\
\text { salários). } \\
\text { Recompensas sociais } \\
\text { ocasionais. Raras } \\
\text { punições ou castigos. }\end{array}$ & $\begin{array}{l}\text { Ênfase nas } \\
\text { recompensas } \\
\text { sociais. } \\
\text { Recompensas } \\
\text { materiais e salariais } \\
\text { freqüentes. Punições } \\
\text { raras e, quando } \\
\text { ocorrem, são } \\
\text { decididas pelos } \\
\text { grupos. }\end{array}$ \\
\hline $\begin{array}{l}\text { Natureza da } \\
\text { Liderança } \\
\text { Aplicada }\end{array}$ & $\begin{array}{l}\text { De forma alguma os } \\
\text { subordinados têm } \\
\text { liberdade para discutir } \\
\text { coisas sobre seu } \\
\text { trabalho com seu } \\
\text { superior. }\end{array}$ & $\begin{array}{l}\text { Os subordinados não } \\
\text { se sentem muito à } \\
\text { vontade para discuti- } \\
\text { las. }\end{array}$ & $\begin{array}{l}\text { Os subordinados têm } \\
\text { alguma oportunidade } \\
\text { de discuti-las. }\end{array}$ & $\begin{array}{l}\text { Os subordinados } \\
\text { sentem-se } \\
\text { absolutamente à } \\
\text { vontade para } \\
\text { discuti-las. }\end{array}$ \\
\hline $\begin{array}{l}\text { Natureza das } \\
\text { forças } \\
\text { motivacionais }\end{array}$ & $\begin{array}{l}\text { Os altos escalões } \\
\text { sentem muita } \\
\text { responsabilidade; os } \\
\text { níveis inferiores } \\
\text { sentem pouca; os } \\
\text { demais, quase } \\
\text { nenhuma - e muitas } \\
\text { vezes esta última } \\
\text { camada dedica-se à } \\
\text { sabotagem das metas } \\
\text { da empresa. } \\
\end{array}$ & $\begin{array}{l}\text { A alta administração } \\
\text { geralmente sente bem } \\
\text { a responsabilidade; o } \\
\text { pessoal subalterno, } \\
\text { por sua vez, sente } \\
\text { pouca } \\
\text { responsabilidade em } \\
\text { ajudar a organização a } \\
\text { alcançar suas metas. }\end{array}$ & $\begin{array}{l}\text { Os funcionários - } \\
\text { sobretudo os dos } \\
\text { níveis hierárquicos } \\
\text { superiores - sentem } \\
\text { bastante } \\
\text { responsabilidade; } \\
\text { geralmente eles } \\
\text { voltam-se com } \\
\text { interesse para o } \\
\text { alcance das metas da } \\
\text { organização. } \\
\end{array}$ & $\begin{array}{l}\text { Os funcionários de } \\
\text { todos os níveis } \\
\text { sentem real } \\
\text { responsabilidade } \\
\text { pelo alcance das } \\
\text { metas da } \\
\text { organização e } \\
\text { comportam-se no } \\
\text { sentido de atingi-las. }\end{array}$ \\
\hline $\begin{array}{l}\text { Natureza do } \\
\text { sistema de } \\
\text { Metas e } \\
\text { Diretrizes }\end{array}$ & $\begin{array}{l}\text { As ordens e } \\
\text { comunicação são } \\
\text { simplesmente } \\
\text { emitidas, sem maiores } \\
\text { comentários. }\end{array}$ & $\begin{array}{l}\text { As ordens e } \\
\text { comunicados são } \\
\text { secamente emitidos, } \\
\text { mas às vezes há } \\
\text { oportunidade de } \\
\text { comentá-los e discuti- } \\
\text { los. }\end{array}$ & $\begin{array}{l}\text { As metas são fixadas e } \\
\text { as ordens emitidas } \\
\text { após discussão com os } \\
\text { subordinados, sendo } \\
\text { então traçado o rumo } \\
\text { a seguir. }\end{array}$ & $\begin{array}{l}\text { Exceto em casos de } \\
\text { emergência, as } \\
\text { metas são } \\
\text { geralmente } \\
\text { estabelecidas } \\
\text { através de ampla } \\
\text { participação grupal. }\end{array}$ \\
\hline
\end{tabular}

Fonte: Transcrição parcial e adaptado de Likert (1975).

No quadro 8, Likert evidencia a Administração Cientifica e as relações existentes com os subordinados argumentando:

A teoria organizacional com base científica, surgida das conclusões das pesquisas sobre administração e desempenho individual, carreia óbvias implicações ao relacionamento subordinado-superior. Esse relacionamento, regra geral, melhora à medida que se aproxima do Sistema 4, o sistema administrativo adotado pela firma. Da mesma forma, qualquer mudança nesse sentido (do Sistema 4) redunda em 
melhoria no relacionamento subordinado-superior; evidentemente, qualquer mudança em direção ao Sistema 1 produz resultado oposto (LIKERT, 1975, p. 176).

Os quatro sistemas apresentados por Likert (1975) constituem um "continuum" que vai desde o sistema 1, autoritário e rígido, passando pelo sistema 2, autoritário benevolente, sistema 3, consultivo, até culminar no sistema 4, participativo e grupal.

Nesse sentido, os estilos de liderança são flexíveis, onde os gerentes podem mudar a orientação para a tarefa e para o funcionário conforme a situação assim o exigir (MONTANA; CHARNOV, 1998; ROBBINS, 2005; SOTO, 2002).

Em 1960 surgiu uma outra variável na definição do processo de liderança - a situação/contexto/meio envolvente, dado que se começou a questionar se as características situacionais podiam funcionar como variáveis moderadoras na relação entre liderança e eficácia grupal, denominada como abordagem situacional (STEFANO; GOMES FILHO, 2003, 2004a).

Essa abordagem tenta identificar quais fatores situacionais são mais importantes e prever que estilo de liderança será mais eficaz numa determinada situação ou momento. Bowditch e Buono (2002), destacam entre os trabalhos a respeito: Fiedler e Hersey-Blanchard, em cujo modelo, as variáveis situacionais básicas são as relações líder-membros (o relacionamento pessoal que o líder tem com os membros do grupo, em termos de confiança e respeito), a estrutura da tarefa (até que ponto a tarefa do grupo está definida), e o grau de poder do cargo do líder sobre seus subordinados.

Este modelo prevê qual tipo de líder poderá ser mais eficaz nas oito combinações possíveis dessas variáveis. Dessa forma, as relações entre líder e subordinados podem ser efetivas ou não, as tarefas estruturadas ou não, e o poder do cargo do líder pode ser grande ou pequeno, combinado com um estilo de gerência voltado para a tarefa ou para o relacionamento.

A abordagem caracterizada por Fiedler sugere que os estilos de liderança são relativamente inflexíveis. Portanto, ou os líderes devem estar adequados a uma situação particular ou a situação deve ser mudada para se adequar ao líder.

De acordo com Montana e Charnov (1998, p. 230), "um líder eficaz, em uma abordagem contingencial, deve entender a dinâmica da situação e adaptar as suas habilidades a essa dinâmica", partindo da premissa de que a liderança eficaz depende da união entre o estilo de liderança e as demandas da situação. Em momentos de grandes mudanças e um 
mercado cada vez mais desafiador, a figura do líder torna-se importante para a obtenção de sucesso e crescimento das organizações.

Segundo Bennis (2001, p. 104),

[...] o autoconhecimento é parte essencial da formulação de um líder. Para tornar-se um líder você deve ser você mesmo, e este preceito é um dos mais difíceis na vida. Mas até que conheça a si próprio, seus pontos fortes e fracos, até que saiba o que fazer e por que, não pode ter sucesso em nada, exceto no sentido mais superficial da palavra.

Para o mesmo autor, o trabalho do líder é variável com a sua idade no cargo e cada fase da liderança traz novas crises e desafios angustiantes, tornando crucial, para a manutenção da tomada ágil de decisões, a capacidade de adaptação do executivo.

No quadro 9 é apresentada a evolução teórica dos estilos e modelos de liderança de Liu, Lepak, Takeuchi e Sims Jr (2003). Para cada estilo foram analisadas várias raízes teóricas de comportamentos específicos de líderes, assim como diversas teorias que podem ser relacionadas ao comportamento dos mesmos.

Quadro 9 - Bases Teóricas de Pesquisas Derivadas de Estilos e Modelos de Liderança

\begin{tabular}{|l|l|}
\hline \multicolumn{1}{|c|}{ Tipo de Liderança } & \multicolumn{1}{c|}{ Bases teóricas de pesquisa } \\
\hline \multirow{5}{*}{ Liderança Diretiva } & $\begin{array}{l}\text { Teoria da Liderança X (McGregor, 1960); } \\
\text { Iniciando estrutura de estudos no Estado de Ohio (Fleishman, 1953); } \\
\text { Comportamento orientado para a tarefa - estudos em Michigan (Katz, } \\
\text { Maccoby, \& Morse, 1950); } \\
\text { Pesquisa de castigo/punção (Arvey \& Ivancevitch, 1980); }\end{array}$ \\
\hline \multirow{5}{*}{ Liderança Transacional } & $\begin{array}{l}\text { Teoria da expectação (Vroom, 1964); } \\
\text { Teoria do caminho-meta (More, 1971); } \\
\text { Teoria da equidade (Adams, 1963); } \\
\text { Teoria da troca (Homans, 1961); } \\
\text { Teoria do reforço (Luthans \& Kreitner, 1985; Sims, 1977; Thorndike, 1911); } \\
\text { Pesquisa da recompensa (Podsakoff, Todor, \& Skov, 1982); }\end{array}$ \\
\hline \multirow{2}{*}{$\begin{array}{l}\text { Liderança Autorizada ou } \\
\text { "Delegada" }\end{array}$} & $\begin{array}{l}\text { Teoria da liderança carismática (More, 1977); } \\
\text { Liderança transformacional (Bass, 1985; Burns, 1978); }\end{array}$ \\
& $\begin{array}{l}\text { Comportamento da administração do ego (Thorenson \& Mahoney, 1974); } \\
\text { Teoria cognitiva social (Bandura, 1986); } \\
\text { Modificação de comportamento cognitivo (Meichenbaum, 1977); } \\
\text { Administração participativa e pesquisa de estabelecimento de metas } \\
\text { participativas (Likert, 1961, 1967; Locke \& Latham, 1990). }\end{array}$ \\
\hline
\end{tabular}

Fonte: Pearce et al. (2000) citado por Liu, Lepak, Takeuchi e Sims Jr (2003). Tradução livre do pesquisador transcrição parcial.

Em um esforço para integrar perspectivas diferentes de liderança, são agrupados quatro estilos, a saber: as lideranças diretiva, transacional, transformacional e a autorizada ou "delegada".

Liu, Lepak, Takeuchi e Sims Jr (2003) afirmam que esses quatro estilos de liderança são distintamente diferentes, pois representam características distinguíveis. Dessa forma, foi 
usada a tipologia de estilos de liderança como base de integração. Devido às características distintas é provável que esses estilos de liderança tenham consequiências variadas para a eficácia do líder.

Uma nova abordagem é relacionada à liderança, a carismática e visionária, em que se torna primordial a valorização das pessoas, propiciando oportunidades para que todos possam aprender, praticar e contribuir de forma efetiva para a organização. A liderança carismática muito se confunde com as características dos líderes transformacionais. Como forma de esclarecer essa semelhança, Robbins (2005, p. 398) assim define “[...] a liderança carismática é um subconjunto da liderança transformacional. A liderança transformacional é o conceito mais amplo, incluindo o carisma". Dentro desse estilo de liderança algumas características são destacadas entre os líderes, tais como: autoconfiança para seu próprio julgamento e suas habilidades; visão onde apresentam uma meta idealizada; habilidade de articulação esclarecendo e formulando sua visão de maneira compreensível para os demais, demonstrando uma compreensão das necessidades dos seguidores, atuando assim como força motivadora; forte convicção (STONER; FREEMAN, 1999, SOTO, 2002).

A pesquisa desenvolvida por Piccolo e Colquitt (2006, p. 327) encontrou efeitos relevantes entre a liderança transformacional e o desempenho da tarefa:

\begin{abstract}
Embora os efeitos da liderança transformacional no desempenho de tarefas e no comportamento organizacional sejam bem documentados, os mecanismos que explicam os efeitos permanecem obscuros. Propomos que a liderança transformacional esteja associada com a maneira que os seguidores vêem seus trabalhos. Os resultados de nosso estudo sustentam um modelo estrutural onde os efeitos indiretos suprem os efeitos mais extremos da liderança transformacional no desempenho de tarefas, e através de mecanismos de características de trabalho, da motivação intrínseca, e do compromisso com os objetivos. Análises adicionais revelaram que as lideranças transformacionais foram significativamente mais fortes para os seguidores que perceberam mudanças de alta qualidade no líder-membro. (tradução do pesquisador) ${ }^{3}$
\end{abstract}

A liderança carismática desperta uma maior motivação e satisfação por parte dos seguidores ao realizarem suas tarefas, pelo simples fato de gostarem de seus líderes. Os líderes que adotam o carisma como seu estilo de liderança, podem aparecer em diversas áreas como na política, na religião, em tempos de guerra ou quando uma empresa estiver introduzindo um

\footnotetext{
${ }^{3}$ Although the effects of transformational leadership on task performance and organizational citizenship behavior $(O C B)$ are well documented, the mechanisms that explain those effects remain unclear. We propose that transformational leadership is associated with the way followers view their jobs. Results of our study support a structural model whereby indirect effects supplement the direst effects of transformational leadership on task performance and through the mechanisms of job characteristics, intrinsic motivation, and goal commitment. Additional analyses revealed that transformational leaderships were significantly stronger for followers who perceived high-quality leader-member exchange.
} 
produto radicalmente novo ou enfrentando uma crise que ameaça sua sobrevivência (STONER; FREEMAN, 1999). Portanto, o líder transformacional ou carismático, possui a capacidade de liderar uma empresa durante uma grande transformação.

Nos últimos três anos a academia de administração americana considerou dois novos tipos de relacionamentos carismáticos, onde os seguidores dos líderes nas organizações podem desenvolver dois tipos diferentes de relacionamentos com o líder: o personalizado e o socializado - e estes relacionamentos conduzem a conseqüências diferentes. De acordo com Howell e Shamir (2005, p. 99),

A essência do relacionamento carismático é uma forte ligação entre os autoconceitos dos seguidores e o líder, a coletividade (grupo, organização, movimento) conduzida pelo líder, e a missão coletiva. Quando existe um relacionamento carismático, os seguidores identificam-se com o líder, o grupo, e a missão coletiva e consideram-nos ao expressar aspectos importantes de seus autos-conceitos. Afirmam que o autoconceito é diferenciado, consistindo em três locus do "eu": o eu como um indivíduo, como um ser interpessoal, e como um membro do grupo. Estes três locus de autodefinições representam orientações distintas de identidade, cada um com sua própria motivação social, fontes de autovalorização, e tipos de autoconhecimento significativos.4 (tradução do pesquisador)

Outros estudos buscaram relacionar a liderança carismática do CEO em diversas empresas nos EUA e Canadá com os impactos nos resultados organizacionais como por exemplo: as pesquisas de Waldman, Ramirez, House na Puranam publicadas em 2001 de Waldman em 2004; de Tosi em 2004 e Agle, Nagarajan, Sonnenfeld e Srinivasan publicadas na Academy of Management Journal em 2006.

Nesse sentido, Agle et all (2006, p. 170-171) afirmam que:

Trabalhos anteriores que usam os mesmos dados relataram um relacionamento entre o carisma do CEO e o desempenho da organização, mas seus autores reconheceram que se dessem seqüência de medidas em sua pesquisa (medida de desempenho organizacional precedendo à de carisma do CEO), não poderiam demonstrar este sentido causal empiricamente. $\mathrm{O}$ argumento de que o carisma é transitório, e argumentos clássicos de Weber (1947) de que o carisma não pode permanecer estável, mas que se torna tradicional ou rotinizado pelo tempo, sugerem que o impacto do carisma do CEO no desempenho de organização é maior na ocupação de um CEO. Assim, nossa análise ocorreu em média após seis anos de posse do CEO,

\footnotetext{
${ }^{4}$ The essence of the charismatic relationship is strong links between followers' self-concepts and the leader, the collectivity (group, organization, movement) led by the leader, and the collective mission.

When a charismatic relationship exists, followers identify with the leader, the group, and the collective mission and regard them as expressing important aspects of their self-concepts.

Contend that the self-concept is multifaceted, consisting of three loci of self: the self as an individual, as an interpersonal being, and as a group member. These three loci of self-definitions represent distinct orientations of identity, each with its own social motivation, sources of self-worth, and types of significant self-knowledge.
} 
se pode ainda discutir que a associação foi significativa e positiva. (tradução do pesquisador $)^{5}$

De acordo com Mueller e Mayer (2003) e Benedetti; Hanashiro e Popadiuk (2003), o homem complexo passa a assumir uma posição de maior destaque dentro da estrutura organizacional. Dessa forma, o desenvolvimento de líderes - facilitadores integrados aos objetivos organizacionais -, faz com que a organização se torne competitiva e à frente de outras organizações.

Num contexto onde as mudanças são constantes e turbulentas, são necessários líderes promotores de mudanças e gestão eficaz e eficiente de pessoas visando o equilíbrio entre os objetivos individuais e organizacionais. Sendo assim, futuros estudos sobre o tema, serão de grande valia no que diz respeito às contribuições e ao surgimento de idéias criativas para organizações que almejem estar em evidência em um mercado competitivo e desafiador, fazendo da liderança a peça chave para tal realização.

Outros estilos de liderança são apresentados por autores como Daft (1999), Soto (2002), Limongi-França e Arellano (2002), o líder transacional e transformacional, que se caracteriza por responder a problemas organizacionais de um modo impessoal, adotam decisões racionais, coordenam e facilitam o trabalho dos outros. Por outro lado, o líder transformacional procura identificar potenciais motivações em seus seguidores, procurando satisfazer as necessidades mais elevadas e engajar o colaborador completamente.

Pesquisas como de Aroma e Da Silva (2003) assinalam que os líderes transformacionais em instituições financeiras influenciam as condições facilitadoras do processo de aprendizagem, enquanto que os transacionais tendem a manter o status quo com menor influência no que tange à aprendizagem, de acordo com a amostra analisada naquele estudo.

O Quadro 10 identifica uma síntese das abordagens de Liderança a partir de 1990, ou seja, uma abordagem contemporânea.

\footnotetext{
${ }^{5}$ Earlier works using the same data reported a relationship between CEO charisma and organizational performance, but their authors acknowledged that given the sequence of measures in their research (measurement of organizational performance preceding measurement of CEO charisma), they could not demonstrate this causal direction empirically. Argument that charisma is transitory, and Weber (1947) classic argument that charisma cannot remain stable, but becomes either traditionalized or routinized over time, both suggest that CEO charisma's impact on organizational performance is greatest earlier in a CEO's tenure. Thus, because our measurement took place on average after six years of CEO tenure, one may still argue that the significant, positive association we found between charisma.
} 
Quadro 10 - Abordagens Contemporâneas de Liderança

\begin{tabular}{|c|c|c|}
\hline Época/Autores & $\begin{array}{c}\text { Teoria ou Abordagem } \\
\text { de Liderança }\end{array}$ & Características/Conceitos de Liderança \\
\hline $\begin{array}{l}\text { Bennis (1993), Boyatizis, } \\
\text { Cameron \& Quinn (1993) }\end{array}$ & $\begin{array}{l}\text { Liderança embasada na } \\
\text { competência }\end{array}$ & $\begin{array}{l}\text { É possível aprender e desenvolver competências } \\
\text { fundamentais que tendem a prever as diferenças } \\
\text { entre o desempenho destacado dos líderes e } \\
\text { liderados. }\end{array}$ \\
\hline $\begin{array}{l}\text { Burns, Kouzes \& Posner } \\
\text { (1995), Peters \& Waterman } \\
\text { (1990), Richards \& Engle } \\
\text { (1986) }\end{array}$ & $\begin{array}{l}\text { Liderança Visionária e } \\
\text { de Aspirações }\end{array}$ & $\begin{array}{l}\text { Liderança é a arte de mobilizar outros a quererem } \\
\text { lutar por aspirações compartilhadas. É uma questão } \\
\text { de articular visões e propiciar o ambiente em que as } \\
\text { coisas podem ser atingidas. Os líderes prosperam em } \\
\text { ambientes caóticos. }\end{array}$ \\
\hline $\begin{array}{l}\text { Drucker (1999), Jacobs \& } \\
\text { Jaques (1990), Kotter (1998), } \\
\text { Buckingham (1999, 2001), } \\
\text { Andrews (1977) }\end{array}$ & $\begin{array}{l}\text { Liderança Gerencial e } \\
\text { Estratégica }\end{array}$ & $\begin{array}{l}\text { A liderança representa a integração entre parcerias } \\
\text { internas e externas. Os líderes desempenham papéis } \\
\text { e possuem características especiais. Os requisitos de } \\
\text { liderança dependem da época e do lugar, bem como } \\
\text { das pessoas e das situações. }\end{array}$ \\
\hline $\begin{array}{l}\text { Ulrich, Zenger \& Smallwood } \\
\text { (1999), Nohria, Joyce \& } \\
\text { Robertson (2003) }\end{array}$ & $\begin{array}{l}\text { Liderança embasada em } \\
\text { Resultados }\end{array}$ & $\begin{array}{l}\text { Marca de liderança que descreve os resultados } \\
\text { específicos que os líderes obtêm. Os líderes são } \\
\text { detentores de caráter, moral, integridade e energia, } \\
\text { além de pensamento estratégico. }\end{array}$ \\
\hline DePree (1992), Tichy (1998) & O líder como Mestre & $\begin{array}{l}\text { Os líderes estabelecem o ponto de vista a ser } \\
\text { ensinado. A liderança efetiva se equaciona ao ensino } \\
\text { efetivo. }\end{array}$ \\
\hline $\begin{array}{l}\text { DePree (1992); Mintzberg } \\
\text { (1998); Vaill (1989) }\end{array}$ & $\begin{array}{l}\text { Liderança como arte } \\
\text { cênica }\end{array}$ & $\begin{array}{l}\text { Os líderes empreendem ações discretas que } \\
\text { abrangem tudo o que o líder ou gerente faz. }\end{array}$ \\
\hline $\begin{array}{l}\text { Fairholm (1994); Senge } \\
\text { (1990); Schein (1992); } \\
\text { Wheatley (1992) }\end{array}$ & $\begin{array}{l}\text { Liderança cultural ou } \\
\text { holística }\end{array}$ & $\begin{array}{l}\text { A liderança é a habilidade de incluir grupos } \\
\text { interessados importantes, evocar companheirismo e } \\
\text { fortalecer outros. A liderança é contextual e } \\
\text { sistêmica (Wheatley). Segundo Senge os líderes } \\
\text { desempenham três papéis: formuladores, } \\
\text { responsáveis e mestres. }\end{array}$ \\
\hline $\begin{array}{l}\text { Greenleaf (1996); Spears \& } \\
\text { Frinck (1992) }\end{array}$ & Liderança Servidora & $\begin{array}{l}\text { Os líderes lideram principalmente servindo outros - } \\
\text { empregadores, clientes e comunidade. } \\
\text { Características do líder: escuta, empatia, cura, } \\
\text { atenção, persuasão, etc. }\end{array}$ \\
\hline $\begin{array}{l}\text { DePree (1989); Etzioni } \\
\text { (1993); Fairrholm (1997); } \\
\text { Greenleaf (1977); Hawley } \\
\text { (1993); Keifer (1992); } \\
\text { Maxwell; Vaill (1989) }\end{array}$ & Liderança Espiritual & $\begin{array}{l}\text { A liderança influencia as almas das pessoas mais do } \\
\text { que controlar suas ações. }\end{array}$ \\
\hline
\end{tabular}

Fonte: Covey (2005, p.350-355). Transcrição parcial e adaptação do pesquisador.

De acordo com Montana e Charnov (1998), dentre muitos estudos já testados e apresentados desde os tempos bíblicos, percebe-se que não existe um estilo ideal de liderança, pois líderes são seres humanos, com fraquezas e instabilidades como qualquer pessoa. Para se chegar ao êxito de uma liderança, existem apenas métodos, caminhos com o qual o líder mais se identifica e que, através dos quais, poderá visar eficazmente os objetivos organizacionais.

A grande missão da atuação do líder em obter sucesso em sua liderança é criar um ambiente no qual as pessoas possam demonstrar suas maiores potencialidades, sentindo-se motivadas e responsáveis diretas pelos resultados alcançados, obtendo assim seguidores em potencial. 
Os seguidores são importantes na equação do líder porque: (1) diferem nas qualidades que trazem para o cargo e, conseqüentemente, exigem ajustes por parte dos lideres; e (2) existem dados sugerindo que os "bons" seguidores exibem características comuns que facilitam o sucesso do líder (ROBBINS, 2005, p. 380).

A liderança visionária vai além do carisma, como afirma Robbins (2005, p. 400): "é a habilidade para criar e articular uma visão do futuro, realista, digna de crédito e atraente, que cresce a partir do presente e o aperfeiçoa”. É necessário saber distinguir exatamente o que é a visão, ou seja, ela é uma declaração de missão e não de metas, é uma realidade, onde quando projetada garante direção, propiciando assim os meios e também o fim, contendo valores que devem ser empreendidos para alcançar o resultado desejado.

A liderança estratégica é definida por Andrews (1977), onde o alto executivo pode ser considerado um líder estratégico, com habilidade analítica, criatividade, autoconhecimento e sensibilidade em relação ao ambiente que o rodeia (ambiente social e competitivo). Ele considera este profissional o "executor" da estratégia, um líder organizacional. O alto executivo pode ser considerado um líder pessoal: uma pessoa diferente das outras, e vai utilizar um estilo de direção para guiar a organização. $O$ estilo não necessariamente define os resultados e eficácia da função do gerente. No entanto, o alto executivo deve examinar seu próprio comportamento para verificar se está de acordo com as necessidades de sua organização e de acordo com os objetivos que deseja atingir.

O mesmo autor afirma que o líder responsável pelo processo estratégico tem a contribuição mais importante que se pode dar em relação à liderança pessoal e as realizações da organização são a projeção da qualidade do líder (como pessoa) para toda a organização. Segundo ele, os objetivos e metas buscados na implementação da estratégia são em parte uma projeção das metas pessoais do líder e um reflexo de seu caráter. O caráter do líder pode ser decisivo para criar uma adesão da organização, em termos de profundidade e qualidade, visando alcançar os objetivos, bem como para enfrentar circunstâncias adversas.

Hitt, Ireland e Hoskisson (2005, p. 376) definem a liderança estratégica como "a capacidade de antecipar, vislumbrar, manter a flexibilidade e capacitar outros a criar chances de estratégia sempre que necessário. Multifuncional por natureza, a liderança estratégica envolve gerenciar por meio de outros, gerenciar uma empresa como um todo, mais do que uma subunidade funcional e cooperar com as mudanças que continuam a aumentar o cenário competitivo."6

\footnotetext{
${ }^{6}$ The ability to anticipate, envision, maintain flexibility, and empower others to create strategic chance as necessary. Multifunctional in nature, strategic leadership involves managing through others, managing an
} 
Nesse sentido, para se atingir objetivos, Ulrich (1999) e Ulrich; Zenger e Smallwood (2000) fundamentam a liderança orientada para resultados embasada no pressuposto da liderança que descreve os resultados específicos que os líderes obtêm. Os líderes são detentores de caráter, moral, integridade e energia, além de pensamento estratégico.

Ulrich; Zenger e Smallwood (2000, p. 20) afirmam que na ultima década “desenvolver melhores líderes consistia em identificar e aprimorar os atributos da liderança". Entretanto, a grande maioria das organizações visa fins lucrativos ou algum tipo de resultado. Assim, ele propõe que a liderança seja orientada para resultados, não subestimando as teorias já elaboradas. O estudo da utilização desses atributos faz-se necessário, então, pois, segundo ele, a liderança eficaz exige atributos aliados a resultados. Com isso, "os atributos que não induzem ou não se conectam com os resultados não são relevantes" e, "os líderes que não estão conseguindo resultados almejados não estão verdadeiramente liderando" (ULRICH; ZENGER; SMALLWOOD, 2000, p.44).

Assim, "a liderança para resultados significa a consecução de algo" (ULRICH; ZENGER; SMALLWOOD, 2000, p.45). É importante salientar que os resultados aqui referidos estão voltados para os quatro principais stakeholders, a saber: empregados, organização, clientes e investidores.

No que se refere ao conjunto de atributos, Ulrich (2000) propõe classificá-los em três grupos que formam a abordagem SER - SABER - FAZER, sendo que os modelos de atributos do líder de sucesso se agrupam em quatro categorias amplas, que são: “definição da trajetória, mobilização do comprometimento pessoal, desenvolvimento das capacidades organizacionais e demonstração do caráter pessoal" (ULRICH; ZENGER; SMALLWOOD, 2000, p.22). De forma que os líderes conectem o que são, sabem, e fazem com resultados.

Para que se alcance o equilíbrio entre os dois fatores, atributos e resultados, o autor propõe um círculo, que ele chama de círculo virtuoso dos atributos e resultados (ULRICH; ZENGER; SMALLWOOD, 2000, p. 213), desencadeado quando os líderes compreendem o que precisam saber e fazer para serem bem sucedidos.

Quando trata dos resultados para os empregados, Ulrich; Zenger e Smallwood (2000) destaca a importância do capital humano, já que o capital intelectual muitas vezes é maior que os ativos tangíveis, e pode ser um problema ou uma oportunidade para a empresa, sendo um dos poucos ativos capaz de aumentar de valor. Ele destaca que a abordagem da liderança para

entire enterprise rather than a functional subunit, and coping with change that continues to increase competitive landscape. 
resultados atribui valor ao conhecimento, à educação, à experiência e à criatividade da força de trabalho, mas reconhece que ainda não se podem mensurar essas qualidades e contribuições de forma exata. "O trabalho do líder consiste em assegurar a produtividade do conhecimento dos empregados e em transformar o capital humano em valor para o cliente" (ULRICH; ZENGER; SMALLWOOD, 2000, p.73).

É função dos líderes identificar fatores capazes de motivar os funcionários de maior potencial, a fim de que se envolvam com as metas e objetivos organizacionais, a partir do que ele chama de sistema VOI2C2E, que significa; visão, ou um objetivo no trabalho; oportunidade ou chances para melhorar no que fazem; visualizar o impacto de seus esforços; incentivos; comunidade, ou seja, fazer parte da equipe; comunicação e empreendedorismo.

Para mensurar a capacidade dos empregados é possível fazê-lo "em termos individuais ou grupais, de forma quantitativa, usando números, ou qualitativa, com base em decisões. Qualquer que seja a abordagem, os líderes devem ser, ao mesmo tempo, rigorosos, efetuando avaliações empíricas, e inquisitivos, por meio de sondagens e perguntas relevantes" (ULRICH; ZENGER; SMALLWOOD, 2000, p.77).

Ao destacar os resultados para a organização, Ulrich; Zenger e Smallwood (2000, p. 101) enfoca que "o desafio da liderança quanto à consecução dos resultados organizacionais se situa na garantia de que o todo é maior do que a soma das partes", sendo que as realizações duram mais que a atuação e energia de um membro isolado e as metas organizacionais sejam mais importantes que o desempenho individual, cultura empresarial compartilhada, capacidade de atuar sem fronteiras organizacionais, aprendizado e disseminação do conhecimento.

Os líderes que enfatizam os clientes criam o valor patrimonial da empresa, para tanto é necessário substituir os mitos: que o cliente tem sempre razão e que se deve encantar o cliente; deve-se sim atender as necessidades e preocupações dos clientes principalmente os clientes-alvo e não "paparicá-los". Por fim, deve-se desmistificar que a coleta de dados sobre os clientes estabelece uma conexão com eles, já que essa se dá pelo envolvimento dos clientes.

Para aumentar o valor para os acionistas podem ser elaboradas estratégias para reduzir custos, aumentar as receitas e aumentar o valor patrimonial da gerência. Os resultados financeiros não devem ser considerados como únicos resultados já que, "muitas ações gerenciais contribuem para o desempenho financeiro" (ULRICH; ZENGER; SMALLWOOD, 2000, p. 189). Então, os líderes devem desenvolver avaliações gerenciais que promovam valor 
aos investidores, ser exemplos de comprometimento, conhecer o setor e a posição da empresa no mesmo e, por fim, comunicar sempre claramente as estratégias aos investidores.

Tornar-se um líder orientado para resultados, para Ulrich; Zenger e Smallwood (2000, p. 191), depende de quatorze iniciativas:

1. Comece com foco absoluto nos resultados.

2. Assuma responsabilidade pessoal e integral pelos resultados do grupo.

3. Comunique as expectativas e alvos ao pessoal do grupo, de forma clara e específica.

4. Determine o que você deve fazer pessoalmente para melhorar os resultados.

5. Utilize os resultados como critério de teste para a continuação ou implementação de práticas de liderança.

6. Envolva-se em atividades e oportunidades de desenvolvimento que o ajudem a produzir melhores resultados.

7. Conheça e utilize ao máximo as capacidades de todos os membros do grupo e ofereça a cada um as oportunidades de desenvolvimento adequadas.

8. Experimente e inove em todas as áreas sob a sua influência, buscando constantemente novas maneiras de melhorar o desempenho.

9. Mensure os padrões certos e aumente o rigor das mensurações.

10. Parta constantemente para a ação; os resultados não são melhorados por si mesmos.

11. Aumente o ritmo ou a velocidade do grupo.

12. Procure o feedback de outros na organização sobre as maneiras como você e seu grupo poderão melhorar os resultados.

13. Assegure-se de que os subordinados e colegas percebem que sua motivação como líder é a obtenção de resultados positivos e não a conquista de ganhos pessoais ou políticos.

14. Modele os métodos e se esforce pelos resultados a serem adotados e obtidos pelo grupo.

Desse modo, todo desenvolvimento de liderança é autodesenvolvimento, cuja manifestação mais poderosa ocorre no próprio trabalho. Todo líder pode adotar medidas no seu cargo atual que contribuirão para a obtenção de resultados; para a obtenção de resultados cada vez melhores, são necessárias fontes de motivações constantes e de revigoramento contínuo do esforço de desenvolvimento que intensifica o desejo de produzir ainda mais resultados (ULRICH; ZENGER; SMALLWOOD, 2000, p. 211). 
Como enfoca Ulrich $(1998,1999)$, o produto da liderança eficaz é simples, ele deve converter aspirações em ações. Aspirações surgem de várias formas: estratégias, metas, missões, visões, previsões e planos. No entanto, a função do líder não é apenas aspirar, mas também agir, convertendo uma declaração de intenção em uma série de condutas. Os líderes precisarão apresentar resultados.

Os líderes estarão menos preocupados em fazer promessas e mais interessados em cumprir o que prometeram. A liderança simbólica sempre será importante, mas o cumprimento coerente, confiável e previsível dos compromissos será o fundamento da liderança.

Neste novo contexto, a liderança tende a ser um processo intencional e baseado na influência, e não no poder posicional da manipulação ou da coerção. A liderança existe quando os seguidores decidem seguir os líderes por acreditar neles e na articulação de suas visões.

As organizações constroem uma marca de liderança orientada para os resultados de acordo com os quatro passos a seguir: 1) Acreditar na importância da liderança; 2) desenvolver uma marca de liderança; 3) avaliar os líderes e encontrar os pontos fracos. 4) investir em liderança (ULRICH, 1999) e (ULRICH; ZENGER; SMALLWOOD, 2000).

No quadro 11 apresentam-se os quatro principais critérios para avaliar o foco nos resultados.

Quadro 11 - Quatro Critérios para avaliar o foco nos resultados

\begin{tabular}{|l|l|}
\hline Equilíbrio & $\begin{array}{l}\text { Os resultados contemplam igualmente quatro partes: os funcionários, a empresa, os } \\
\text { clientes e os acionistas. }\end{array}$ \\
\hline Estratégia & $\begin{array}{l}\text { Os resultados estão de acordo com a estratégia e os objetivos da empresa? Como se } \\
\text { relacionam com o foco da empresa e com a proposição de valor aos clientes escolhidos? } \\
\text { Por que os clientes compram seus produtos ou serviços? }\end{array}$ \\
\hline Duração & Os resultados geram ganhos em curto prazo sem inibir ou evitar o êxito no longo prazo? \\
\hline Generosidade & $\begin{array}{l}\text { Os resultados impulsionam toda a empresa à frente e não apenas a carreira dos líderes ou } \\
\text { o sucesso do departamento? Constroem habilidades organizacionais? }\end{array}$ \\
\hline
\end{tabular}

Fonte: Ulrich (1999) e Ulrich; Zenger; Smallwood (2000). Transcrição parcial e adaptação do pesquisador.

Ulrich (1999) e Ulrich; Zenger e Smallwood (2000) relatam que a qualidade de uma empresa não está em sua estrutura, mas sim no conjunto de talentos que a compõem. Uma organização tem habilidades que a ajudam a atuar e a vencer, e elas devem estar relacionadas antes de tudo com a estratégia organizacional. Só depois desse passo são definidas as habilidades necessárias para cumprir seu objetivo, sendo que existem quatro tipos de habilidades: as que envolvem funcionários, clientes, acionistas e a organização. As habilidades que dizem respeito à organização são a essência das habilidades que contam para 
o futuro. E os líderes voltados para resultados se concentram em promover as habilidades organizacionais: liderança, cultura empresarial partilhada, capacidade de atuar sem fronteiras organizacionais, aprendizado e disseminação de conhecimento, maior responsabilidade para entregar o que prometem e maior velocidade.

Corroborando com essa visão DuBrin (1998, p. 5-6) relata o impacto da liderança no desempenho organizacional, onde o líder pode contribuir para resultados positivos ou negativos:

Uma suposição subjacente ao estudo da liderança é que os líderes afetam o desempenho organizacional. Os líderes, com suas ações e influência pessoal, causam a mudança. As pessoas que controlam as organizações -muitos executivos - fazem a mesma suposição. Um antídoto freqüente aos maiores problemas é a mudança do líder, na esperança que aquele recentemente apontado irá reverter os problemas de desempenho. Um exemplo desta suposição na ação é a recolocação freqüente de treinadores esportivos após uma ou duas temporadas perdedoras. Os proprietários, ou os diretores das escolas, entendem que o discernimento de liderança do novo treinador irá melhorar o rateio entre ganhos e perdas. ${ }^{7}$ (tradução do pesquisador)

Ulrich (1999) e Ulrich; Zenger e Smallwood (2000) afirmam que o coaching é um dos modos de investir na formação de líderes. Funciona porque começa com uma análise das predisposições de um potencial líder. Um coach percebe a tendência para a introversão, um aspecto da personalidade. Com essa orientação, o líder pode aperfeiçoar a maneira de atuar e atingir melhores resultados. Bons coaches ajudam os líderes a aprender os comportamentos que conduzem a melhores resultados.

Quadro 12 - Seis Passos para Desenvolver as Habilidades dos Funcionários

\begin{tabular}{|l|l|}
\hline Aquisição & $\begin{array}{l}\text { Traga novos talentos por meio do recrutamento de profissionais de fora da empresa ou de } \\
\text { outros departamentos da organização. }\end{array}$ \\
\hline Construção & Desenvolva o talento com treinamento na função, rotatividade de tarefas e empowerment. \\
\hline Benchmarking & $\begin{array}{l}\text { Visite empresas que sirvam como referência nos processos profissionais voltados para o } \\
\text { desenvolvimento. }\end{array}$ \\
\hline $\begin{array}{l}\text { Busca de } \\
\text { recursos }\end{array}$ & $\begin{array}{l}\text { Faça parcerias com consultores, vendedores, clientes ou fornecedores de fora da empresa } \\
\text { para reunir novas idéias. }\end{array}$ \\
\hline Demissão & Elimine profissionais com desempenho baixo ou inadequado. \\
\hline Retenção & Conserve os funcionários mais talentosos. \\
\hline
\end{tabular}

Fonte: Ulrich (1999) e Ulrich; Zenger e Smallwood (2000). Transcrição parcial e adaptação do pesquisador.

\footnotetext{
${ }^{7}$ An assumption underlying the study of leadership is that leaders affect organizational performance. Leaders, through their actions and personal influence, bring about change. People who control organizations - the very to executives - make the same assumption. A frequent antidote to major organizational problems is to replace the leader, in the hope that the newly appointed leader will reverse performance problems. An example of this assumption in action is the frequent replacement of athletic coaches after one or two losing seasons. The owners, or school officials, assume that the leadership acumen of the new coach will vastly improve the ratio of wins to losses.
} 
Para DuBrin (1998, p. 365), são diversos os fatores culturais que influenciam a prática da liderança. Um líder multicultural é um líder com habilidades e atitudes para relacionar-se eficazmente e para motivar pessoas de diferentes raças, gêneros, idades, atitudes sociais e estilos de vida. Para influenciar, motivar e inspirar pessoas com culturas diversas, o líder deve estar ciente das diferenças culturais sutis. Tais diferenças são generalizações, mas funcionam como pontos de partida na tentativa do líder em conduzir uma pessoa de outra cultura. Por exemplo: muitos asiáticos são autoconscientes sobre ser elogiados na frente do grupo, porque sentem que a atenção individual colide com seu desejo de manter a harmonia do grupo. Um gerente deve conter-se em elogiar um membro asiático à frente do grupo até que ele ou ela entenda as suas preferências. O gerente poderá pensar que muitos asiáticos gostam de ser elogiados na frente de seus companheiros, especialmente quando trabalham fora de sua terra natal.

Aqui são examinados três tópicos que ajudam um líder a aprender como gerenciar um local de trabalho com culturas diferentes: 1) entender as dimensões-chave nas diferenças dos valores culturais; 2) aplicar um modelo motivacional através dos grupos culturais; e 3) entender as diferenças no estilo de liderança. ${ }^{8}$

A cultura de um país influencia os estilos de liderança por parte dos liderados de suas organizações, e os líderes não são livres para escolher qualquer estilo que prefiram, pois têm limitações impostas pelas condições culturais que determinam as expectativas de seus liderados. Como exemplo, DuBrin (1998) cita que os líderes coreanos devem ser paternalistas; os árabes que demonstram amabilidade são considerados fracos; os japoneses devem ser humildes e falar pouco; os escandinavos e holandeses, quando elogiam um funcionário publicamente, conseguem embaraçar o funcionário. O autor cita que as teorias de liderança foram desenvolvidas nos EUA, com um viés norte-americano, com mais ênfase nas responsabilidades do que nos direitos dos liderados, enfatizando a racionalidade, a

\footnotetext{
${ }^{8}$ A multicultural leader is a leader with the skills and attitudes to relate effectively to and motivate people across race, gender, age, social attitudes, and lifestyles. To influence, motivate, and inspire culturally diverse people, the leader must be aware of overt and subtle cultural differences. Such culturally based differences are generalizations, but they function as starting points in the leader's attempt to lead a person from another culture. For example, many Asians are self-conscious about being praised in front of the group because they feel that individual attention clashes with their desire to maintain group harmony. A manager might refrain from praising an Asian group member before the group until he or she understands that group member's preferences. The manager is likely to find that many Asians welcome praise in front of peers, especially when working outside their homeland.

Here we examine three topics that help a leader learn how to manage in a culturally diverse workplace: 1) understanding key dimensions of differences in cultural values; 2) applying a motivational model across cultural groups; and 3) understanding cross-cultural differences in leadership style.
} 
centralização do trabalho, valores democráticos e hedonismo, em vez do comprometimento com o trabalho.

Segundo Hofstede (2003, p. 60), as teorias americanas de liderança partem do pressuposto que os subordinados têm necessidades de dependência de nível médio: nem muito altas, nem muito baixas. Uma das idéias chave é a "gestão participativa", ou seja, situações em que os subordinados são convidados pelos supervisores a participar nas decisões da organização. Nas experiências de "democracia empresarial” de países como a Suécia ou Dinamarca, os subordinados tomam frequentemente iniciativas de participação, não tendo sucesso nas empresas americanas e vice-versa.

Tanure e Duarte (2006) relatam que os executivos são os executores das políticas organizacionais, e a esses profissionais não bastam ser dotados de liderança, ter facilidade de articulação, percepção aguçada, capacidade de desenvolver habilidades específicas e vasto arsenal de conhecimentos e qualificações. É necessário que eles sejam capazes de apreciar, valorizar e gerenciar a diversidade humana e cultural, administrar processos de mudanças e enxergar cenários mais amplos, com a habilidade de identificar mercados e competidores potenciais e novas fontes de tecnologia, de conhecimento, de recursos humanos e financeiros. O fundamental desse executivo internacional é saber conviver com paradoxos, ou seja, gerenciar forças contraditórias e conflitos.

Robbins (2002, p. 325) cita que nas pesquisas realizadas sobre liderança nas organizações, observou-se que os líderes eficazes não utilizam um único estilo. Eles ajustam seu estilo às situações; a cultura de um país é um importante fator na determinação de qual estilo de liderança poderá ser mais eficaz. Portanto, é mais uma variável contingencial a ser considerada.

Um outro elemento importante que pode afetar diretamente os resultados dos líderes organizacionais são as formas de poder, que está tratado no tópico seguinte.

\subsection{Poder}

O poder já foi definido de várias formas, mas em sua essência sempre aparece a idéia de controle ou influência do comportamento de uma parte sobre a outra. Porém, o poder não é um atributo do ator social em si mesmo, e sim uma característica de todas as relações sociais, tanto individuais como grupais (MONTANA; CHARNOV, 1998). 
De acordo com os mesmos autores, poder é a habilidade de influenciar subordinados e colegas por meio do controle de recursos organizacionais - é o que distingue a posição de liderança. Um líder bem sucedido usa o poder para influenciar os outros eficazmente, e é importante que se entenda as fontes de poder para realçar a função de liderança.

Mesmo quando não é manifestado ostensivamente, o poder é uma influência potencial e basta ser percebido para que influencie comportamentos, sem que seja efetivamente exercido. E tem mais: devido à reciprocidade das relações sociais, existe certa interdependência entre as partes, e ambas têm alguma dose de poder. Tal característica conduz ao conceito de vantagem ou equilíbrio no poder. Em qualquer vínculo, as partes tentam reequilibrar a relação, modificando a natureza da dependência.

Weber (1970) estabelece uma distinção básica entre poder e autoridade. Segundo ele o poder envolve a força ou a coerção e não seria um fator importante como processo interno das organizações. A autoridade é uma forma de poder que não implica força. Ao contrário, envolve uma "suspensão do julgamento" por parte dos que se submetem a ela. As diretrizes ou ordens são seguidas porque se acredita que devam ser seguidas. A obediência é voluntária.

O mesmo autor identificou três formas de autoridade em seus estudos sobre o modelo burocrático. A autoridade legal ou estatutária, a tradicional e a carismática. A legal ou estatutária corresponde às expectativas do cargo, com respeito às normas impostas e ao líder outorgado. Considera-se que a burocracia encaixa-se na autoridade legal, uma vez que se torna eficiente na medida em que as normas, regras e ordens são cumpridas. A tradicional diz respeito ao poder exercido pelos clãs, pela família, pelos senhores medievais. Normalmente, é estabelecida pelos costumes, crenças e hábitos. E, na carismática o líder é eleito pelo grupo e não imposta pela cúpula (VENDRAMINI, 2000).

As correntes teóricas trazem as características que marcam a personalidade do líder e a forma como ele deveria atuar em cada situação. Assim, não se pode ignorar a contribuição do político pensador Maquiavel, o qual discutia as atribuições do príncipe para a conquista e manutenção de principados, em sua obra (MAQUIAVEL, 1976).

A obra "O Príncipe" foi publicada em 1513 e afirma "que os líderes precisam de firmeza e da preocupação suprema de manter o poder, a autoridade e a ordem no exercício do governo" (OLIVEIRA, 2007. p.5).

Maquiavel traz em sua obra um conjunto de recomendações aos príncipes de como conquistar e manter a região conquistada, de tal sorte que é imprescindível ter a força de um 
leão, a astúcia de um lobo e a virtu, entendida como qualidades superiores, ainda que voltadas para o interesse próprio (VENDRAMINI, 2000).

Para Maquiavel o príncipe precisa manter o poder dominando a arte de usar tanto o método da lei (próprio dos seres humanos), quanto o da força (típicos dos animais), que são considerados dois métodos básicos (OLIVEIRA, 2007).

Por fim, "Maquiavel mostra-se despreocupado com os meios utilizados, o que importa são os fins almejados. Se o objetivo final he for conveniente, é possível valer-se de quaisquer recursos para chegar ao resultado almejado. O lema que o imortaliza é de que os fins justificam os meios" (VENDRAMINI, 2000, p.3).

De acordo com Montana e Charnov (1998), são seis os tipos de poder organizacional: o poder legítimo, o poder de recompensa, poder coercitivo, poder de especialização ou expertise, poder de referência e poder de informação.

O poder legítimo é o poder inerente à estrutura organizacional em si. Esse poder é atribuído a um indivíduo que ocupa uma posição específica dentro da organização. Caso o indivíduo deixe o cargo, o poder continua a existir na posição e não pode seguir o indivíduo. Esse poder é legítimo na organização e o indivíduo é investido de poder.

O poder de recompensa também é inerente à estrutura organizacional. Pelo fato de os funcionários subordinados desejarem as recompensas, eles são influenciados pela possibilidade de recebê-las como produto de seu desempenho. As recompensas organizacionais podem ser óbvias - por exemplo, promoções - e, podem ser sutis - elogio do gerente, status, outros.

O poder coercitivo está ligado à habilidade do gerente em punir um funcionário. A punição se manifesta de várias maneiras, indo de uma simples advertência, até uma suspensão, ou o desligamento efetivo. Um ponto importante a se lembrar: punir ou ameaçar de punição não promove o desempenho desejado do funcionário - apenas intimida as ações indesejadas. Mesmo que a punição não promova o comportamento que se quer, servindo apenas para intimidar ações indesejadas, ela é uma ferramenta gerencial poderosa. A habilidade de um gerente em punir os trabalhadores pode ser reprimida pelos contratos sindicais ou pela aplicação das leis trabalhistas antidiscriminatórias (MONTANA; CHARNOV, 1998).

As punições devem ser aplicadas de acordo com a ofensa que as originou. Quando a administração dispõe de punições que vão desde a mais suave até a mais severa, ela pode ser 
flexível. Vários princípios gerais governam a aplicação da punição - o uso do poder coercitivo - dentro de um ambiente organizacional.

O poder de especialização está ligado às habilidades de um gerente. Esse poder deriva de talentos especiais, do conhecimento, das habilidades e da experiência anterior de um indivíduo. Esses talentos concedem poder ao indivíduo, pois a organização precisa deles e os valoriza. $\mathrm{O}$ poder, que deriva de um conhecimento especial ou educação avançada, pode não estar relacionado com a idade ou o tempo de serviço. Essa forma de poder permite que uma pessoa relativamente jovem ou nova na força de trabalho ganhe influência dentro da organização.

O poder de referência, muitas vezes chamado de carisma pessoal, é o poder de um indivíduo de influenciar um outro por sua força de caráter. Um gerente pode ser admirado por uma característica pessoal específica, e essa admiração cria a oportunidade para a influência interpessoal.

O poder da informação deriva da posse de informação importante em um momento crítico quando esta é necessária ao funcionamento da organização. A posse de informação pode não ter relação alguma com a posição organizacional ou poder atribuído a um indivíduo.

As bases do poder são aquilo que os indivíduos ou grupos controlam e que os torna capazes de manipular o comportamento de outrem. De acordo com Hall (1984), há quatro fontes de poder nas organizações, as quais são entendidas como a maneira como as partes passam a controlar as bases do poder: 1) o cargo ou a posição estrutural; 2) as características pessoais, como o carisma; 3) a especialização, que é tratada como fonte e como base do poder; 4) a oportunidade ou a combinação de fatores que dá às partes a chance de utilizarem suas bases de poder. Portanto, essas fontes são utilizadas nas situações do poder de autoridade e de influência. À medida que o poder é exercido, seu detentor utiliza as bases de poder disponíveis.

Quadro 13 - Atributos Pessoais que são Fontes de Poder

\begin{tabular}{|l|l|}
\hline $\begin{array}{l}\text { Energia, } \\
\text { resistência e } \\
\text { força Física }\end{array}$ & $\begin{array}{l}\text { A capacidade e a disposição de trabalhar longas horas são cruciais a quem pretende ter } \\
\text { poder, porque o esforço e a dedicação permitem superar aqueles que têm mais vantagens } \\
\text { em inteligência ou habilidades. }\end{array}$ \\
\hline Foco & $\begin{array}{l}\text { Quem exerce o poder sabe que a energia não é infinita e concentra seus esforços em uma } \\
\text { única direção. Por isso, em vez de se diversificar, adota um foco quase obsessivamente. }\end{array}$ \\
\hline Flexibilidade & $\begin{array}{l}\text { Trata-se da capacidade de apelar para distintos recursos de acordo com as circunstâncias. } \\
\text { A flexibilidade é um atributo importante para quem pretende exercer o poder, porque está } \\
\text { relacionada com a habilidade de mudar o rumo e adotar novas abordagens em lugar de se } \\
\text { ater àquelas que não dão resultado. }\end{array}$ \\
\hline $\begin{array}{l}\text { Sensibilidade } \\
\text { em relação aos } \\
\text { outros }\end{array}$ & $\begin{array}{l}\text { Significa entender suas preferências e atitudes e perceber qual é a melhor maneira de se } \\
\text { comunicar com eles. Em outras palavras, trata-se de saber "ler" as pessoas. Os indivíduos }\end{array}$ \\
\hline
\end{tabular}




\begin{tabular}{|l|l|}
\hline & $\begin{array}{l}\text { sensíveis são capazes de esquecer suas próprias necessidades e crenças e se identificar } \\
\text { com as dos outros. }\end{array}$ \\
\hline $\begin{array}{l}\text { Tolerância ao } \\
\text { conflito }\end{array}$ & $\begin{array}{l}\text { Quando todos estão de acordo, não há necessidade de exercer poder. Por isso, um atributo } \\
\text { crucial dos poderosos é sua capacidade de se envolver em conflitos. Com frequência, as } \\
\text { pessoas que demonstram seus pontos de vista (mesmo as que se impõem agressivamente) } \\
\text { obtêm mais do que as que evitam problemas. }\end{array}$ \\
\hline $\begin{array}{l}\text { Afabilidade e } \\
\text { boa disposição }\end{array}$ & $\begin{array}{l}\text { "Domesticar" o ego, mesmo que temporariamente, e ser flexível ajuda a adequar o } \\
\text { comportamento para aumentar o poder. O ego "forte" é um obstáculo às alianças; quem o } \\
\text { controla forma seguidores. }\end{array}$ \\
\hline
\end{tabular}
Fonte: Pfeffer (2006, p.3). Transcrição integral.

Os atributos pessoais que são listados no quadro 13 contribuem substancialmente para o desempenho dos líderes no contexto organizacional, pois são orientados para resultados e também para os colaboradores da organização.

Os resultados dos atos de poder para a organização e seus participantes são relacionados por Hall (1984) como algumas conseqüências das relações de poder:

a) Obediência e envolvimento: é a conseqüência mais freqüente do ato de poder. Eles são fenômenos inter-relacionados. As organizações voluntárias contam com o envolvimento moral, pois aparentemente aumenta quando os membros são incentivados a participar e de fato o fazem. Dessa forma, a participação contribui para a obediência através do processo de envolvimento;

b) Conformismo: pode ser comportamental ou atitudinal. No primeiro, o receptor do poder obedece sem uma internalização das normas envolvidas, já no atitudinal há ao mesmo tempo obediência e internalização. Portanto, utilizam-se bases de poder múltiplas em uma única organização;

c) Percepções da autoridade: é um fenômeno relacional, ou seja, a maneira como o receptor do poder percebe o exercício do poder;

d) Poder e participação: quando os receptores do poder adquirem especialização antes da participação; seu poder aumenta em relação ao do detentor do poder;

e) Poder e comunicações: o sistema de comunicações em uma organização também é afetado pelas disposições de poder. As comunicações podem ser centralizadas na cúpula da organização até o modelo totalmente descentralizado de comunicações;

f) Relações horizontais e verticais de poder: a dimensão vertical é apenas parte das relações de poder nas organizações. As relações interdepartamentais, entre linha e staff e entre profissionais liberais e organizações são da dimensão horizontal. 
O entendimento dos tipos, fontes e relações de poder é fundamental para as organizações e seus colaboradores, pois a gestão de negócios e a gestão estratégica de pessoas é permeada por essas variáveis.

\subsection{Cultura Organizacional}

O termo cultura é bastante antigo e seu significado vem se modificando ao longo dos anos, nos quais sofreu influência da sociedade romana e européia, da antropologia, da sociologia e da psicologia. Ela consiste de ferramentas, implementos, utensílios, vestimentas, armamentos, costumes, instituições, crenças, rituais, jogos, obras de arte, linguagem, entre outras.

De acordo com Fleury e Sampaio (2002, p. 284), a cultura é definida como "um complexo total de conhecimentos, crenças, artes, moral, leis, costumes e quaisquer outras aptidões e hábitos adquiridos pelo homem como membro da sociedade".

Somente a partir do final da década de 1950 é que o conceito de cultura foi incorporado às ciências administrativas, porém ainda há algumas divergências entre os diversos autores, como se pode constatar no quadro 14 .

Quadro 14- Conceitos de Cultura Organizacional e Autores

\begin{tabular}{|c|c|}
\hline Autores & Conceitos de Cultura Organizacional \\
\hline Hofstede (1980) & $\begin{array}{l}\text { É a programação coletiva da mente que diferencia os membros de um grupo } \\
\text { humano de outros. Segundo este autor, o sistema de valores é responsável pela } \\
\text { programação mental, pois constituem a centralidade da cultura. }\end{array}$ \\
\hline Schein (1992) & $\begin{array}{l}\text { Cultura organizacional é um padrão de assuntos básicos compartilhados que um } \\
\text { grupo aprendeu como maneira de resolver seus problemas de adaptação externa e } \\
\text { integração interna, e que funciona bem a ponto de ser considerado válido e } \\
\text { desejável para ser transmitido aos novos membros como a maneira correta de } \\
\text { perceber, pensar e sentir em relação àqueles problemas. }\end{array}$ \\
\hline Araujo (2006, p. 308) & $\begin{array}{l}\text { É o conjunto de valores, crenças e padrões de comportamento que formam o } \\
\text { núcleo de identidade de uma organização. }\end{array}$ \\
\hline Santos $(2000$, p. 38) & $\begin{array}{l}\text { Valores e crenças compartilhados pelos membros de uma organização, a qual } \\
\text { funciona como um mecanismo de controle organizacional, informalmente } \\
\text { aprovando ou proibindo comportamentos e que dá significado, direção e } \\
\text { mobilização para os membros da organização. }\end{array}$ \\
\hline Bitencourt (2004, p. 448) & $\begin{array}{l}\text { A rede de significações que circulam dentro e fora do espaço organizacional, } \\
\text { sendo simultaneamente ambíguas, contraditórias, complementares, díspares e } \\
\text { análogas, implicando ressemantizações que revelam a homogeneidade e a } \\
\text { heterogeneidade organizacional. }\end{array}$ \\
\hline $\begin{array}{l}\text { Fleury e Sampaio }(2002, \\
\text { p. 293) }\end{array}$ & $\begin{array}{l}\text { Conjunto de valores e pressupostos básicos, expressos em elementos simbólicos } \\
\text { que, em sua capacidade de ordenar, atribuir significações, construir a identidade } \\
\text { organizacional, tanto agem como elemento de comunicação e consenso como } \\
\text { ocultam e instrumentalizam as relações de dominação }\end{array}$ \\
\hline Robbins (2002, p. 498) & $\begin{array}{l}\text { É uma percepção comum compartilhada pelos membros de uma organização; um } \\
\text { sistema de valores compartilhados. }\end{array}$ \\
\hline
\end{tabular}




\begin{tabular}{|l|l|}
\hline $\begin{array}{l}\text { Lacombe e Heilborn } \\
(2003, \text { p. 354) }\end{array}$ & $\begin{array}{l}\text { É o conjunto de valores em vigor em uma empresa, suas relações e sua hierarquia, } \\
\text { definindo os padrões de comportamento e de atitudes que governam as ações e } \\
\text { decisões mais importantes da administração }\end{array}$ \\
\hline $\begin{array}{l}\text { Wagner III e Hollenbeck } \\
(1999, \text { p. } 367)\end{array}$ & $\begin{array}{l}\text { É uma maneira informal e compartilhada de perceber a vida e a participação na } \\
\text { organização, que mantém os seus membros unidos e influencia o que pensam } \\
\text { sobre si mesmos e seu trabalho }\end{array}$ \\
\hline
\end{tabular}

Fonte: Hofstede (1980), Schein (1992), Araujo (2006, p. 308), Santos (2000, p. 38), Bitencourt (2004, p. 448), Fleury e Sampaio (2002, p. 293), Robbins (2002, p. 498), Lacombe e Heilborn (2003, p. 354), Wagner III e Hollenbeck (1999, p. 367). Transcrição parcial.

Percebe-se que os valores, as crenças e os padrões de comportamento são os pilares do núcleo da identidade organizacional e estão interligados e em permanente aperfeiçoamento.

Hitt, Ireland e Hoskisson (2005, p. 390) entendem a cultura organizacional como um conjunto complexo de ideologias, símbolos e valores-chave compartilhados por toda a empresa e que influenciam a maneira como o negócio é administrado. As evidências sugerem que uma empresa pode desenvolver competências essenciais em termos tanto das suas habilidades quanto da forma como essas aptidões são alavancadas por estratégias, de modo a produzirem os resultados desejados. Em outras palavras, visto que a cultura organizacional influencia a forma como a empresa conduz seu negócio, ajudando, também, a regular e controlar o comportamento dos funcionários, ela pode ser então uma fonte de vantagem competitiva. Dessa forma, moldar o contexto no qual a empresa formula e implementa suas estratégias - isto é, moldar a cultura organizacional - apresenta-se como a tarefa principal dos líderes estratégicos. ${ }^{9}$

Hofstede (2003, p. 25) relata que "cada indivíduo pertence a vários grupos ou categorias em simultâneo, sendo assim portador de níveis de programação mentais diferentes, que correspondem a diferentes níveis de cultura”, como: a) um nível nacional: país de origem ou que migraram; b) um nível correspondente ao grupo que pertence: regional, étnico, religioso, lingüístico; c) um nível de gênero: masculino ou feminino; d) um nível de geração: avós, pais e filhos; e) um nível correspondente à origem social: escolaridade ou profissão exercida; f) nível ligado à organização ou empresa: como são socializados, entre outros.

De acordo com o mesmo autor, poderiam existir diversos outros níveis, e não estão necessariamente em harmonia. Os valores em conflito no indivíduo tornam difícil a antecipação do seu comportamento em novas situações.

\footnotetext{
${ }^{9}$ An organizational culture consists of a complex set of ideologies, symbols, and core values that is shared throughout the firm and influences the way business is conducted. Evidence suggests that a firm can develop core competencies in terms of both the capabilities it possesses and the way the capabilities are leveraged by strategies to produce desired outcomes. In other words, because the organizational culture influences how the firm conducts its business and helps regulate and control employees' behavior, it can be a source of competitive
} 
Autores como Robbins (2002) e Johann (2004) afirmam que a cultura organizacional deriva da filosofia dos seus fundadores que influenciam os critérios usados na contratação de mão-de-obra. As ações dos dirigentes da empresa é que designam quais comportamentos são aceitáveis. As práticas de cada organização são repassadas a todos os colaboradores, inclusive os novos, através da socialização e, segundo Cohen e Fink (2003), as pessoas são influenciadas pelo que acontece em volta delas e reagem ao que percebem como sendo as expectativas gerais.

Para Schein (1992), alguns aspectos críticos em relação à cultura organizacional estão relacionados a idéia que determinadas coisas nos grupos estão compartilhadas ou são realizadas. As categorias principais de tais fenômenos neste sentido são as seguintes: 1) comportamentos regulares observados da interação das pessoas; 2) normas do grupo; 3) valores depositados; 4) filosofia formal; 5) regras do jogo; 6) clima organizacional; 7) habilidades necessárias; 8) hábitos do pensamento; 9) significados compartilhados; 10) símbolos de integração. Dessa forma, os processos dinâmicos de criação, desenvolvimento, mudança, controle e de gerência da cultura organizacional são a essência da liderança e fazem com que esta e a cultura sejam dois lados da mesma moeda.

A maioria das grandes organizações possui uma cultura dominante e diversos nichos de subculturas. A cultura dominante é aquela conhecida por todos, já as subculturas dizem respeito às miniculturas existentes em alguns departamentos da organização. "Quanto mais forte a cultura organizacional, menos os administradores precisam se preocupar em desenvolver regras e regulamentos para orientar o comportamento dos funcionários" (ROBBINS, 2002, p. 502).

Ainda, em conformidade com Johann (2004), identificam-se, no quadro 15, os tipos de cultura organizacional, bem como seus conceitos chaves:

Quadro 15 - Tipos e Conceitos de Cultura Organizacional

\begin{tabular}{|l|l|}
\hline Tipo & Conceito \\
\hline Cultura Corporativa & $\begin{array}{l}\text { Confere uma identidade comum às pessoas que pertencem ao quadro funcional } \\
\text { de uma grande empresa. }\end{array}$ \\
\hline $\begin{array}{l}\text { Cultura Organizacional de } \\
\text { Alto Desempenho }\end{array}$ & $\begin{array}{l}\text { É o estágio evoluído da cultura organizacional de uma empresa, que norteia a } \\
\text { aça das pessoas para a obtenção de resultados efetivos, de forma continuada. É } \\
\text { também adaptativa e flexível, na medida em que é capaz de absorver } \\
\text { continuamente novos valores culturais. }\end{array}$ \\
\hline $\begin{array}{l}\text { Cultura Organizacional } \\
\text { Densa }\end{array}$ & $\begin{array}{l}\text { Possui um alto grau de valores e crenças compartilhados, orientando o } \\
\text { comportamento de todos. Tem um ambiente com pouca discórdia ou } \\
\text { ambigüidade. }\end{array}$ \\
\hline
\end{tabular}

Fonte: Johann (2004). Transcrição parcial.

advantage. Thus, shaping the context within which the firm formulates and implements its strategies - that is, shaping the organizational culture - is a central task of strategic leaders. 
Pode-se dizer que cada organização possui uma cultura única, a qual confere identidade aos seus membros. A cultura organizacional de uma empresa pode ser de alto desempenho, densa e/ou corporativa.

Fleury e Sampaio (2002) afirmam que os estudos sobre cultura têm um caráter histórico mais profundo, remetendo as origens da organização ao processo de definição de seus valores básicos e padrões culturais. O processo de diagnóstico, tanto quanto as intervenções sobre a cultura de uma organização, atestam as dificuldades que se têm de trabalhar com um fenômeno mais complexo e profundo. Assim, por exemplo, em um diagnóstico de cultura, é necessário trabalhar com uma perspectiva histórica, observando com atenção o contexto em que foi criada a organização, bem como o papel do seu fundador.

Robbins (2002) destaca que a cultura desempenha diversas funções dentro de uma organização, tais como: cria distinção entre uma organização e outras; proporciona senso de identidade aos seus membros; facilita o comprometimento com a empresa; estimula a estabilidade do sistema social; ajuda a manter a organização coesa e serve como sinalizador de sentido e mecanismo de controle.

Também é comentado no meio organizacional que "assim como a cultura de uma empresa pode alavancar seus negócios, quando deteriorada pode também contaminar a imagem e a própria marca da organização" (JOHANN, 2004, p. 143). Afinal, é a cultura que define a missão e provoca o nascimento e o estabelecimento dos objetivos da organização. Assim sendo, é condizente a idéia de Araújo (2006), de que as pessoas devem conhecer a cultura das empresas por três motivos: i) porque ela define fronteira clara para todos os membros da empresa, ou seja, as normas e regulamentos delimitam as atitudes das pessoas dentro das organizações; ii) porque ela apresenta um modo consistente de abordar novas situações e iii) porque ela ajuda a unir as pessoas, garantindo um padrão conhecido de sucesso.

De acordo com Robbins (2002), Araújo (2006), Wagner III e Hollenbeck (1999), os funcionários de uma empresa aprendem a cultura organizacional através de várias maneiras: histórias, ritos, rituais, cerimônias, mitos, heróis, símbolos, linguagem, regras e regulamentos, ambiente organizacional, microculturas e contraculturas. Esse aprendizado ocorre por diversos meios como: documentos escritos, reuniões, seminários, palestras, treinamentos, orientações, exemplos, divulgação na mídia dos valores e princípios, processos de recrutamento, seleção e ambientação, reconhecimento dos profissionais, estilo de liderança dominante, o projeto físico dos edifícios e das instalações, a estrutura formal da empresa, entre outros. 
Em determinados momentos da organização uma cultura muito forte pode afetar a eficácia da empresa, se tornando uma barreira às mudanças (quando "trabalhar como sempre" não é mais eficaz), à diversidade (ao eliminar as diferenças que as pessoas com históricos diversos levam para ela) e às aquisições e fusões (que só deverão ocorrer quando as culturas forem compatíveis), como bem lembra Robbins (2002).

No entanto, Stoner e Freeman (1999) relatam que para mudar uma cultura organizacional é preciso concentrar esforços nas pessoas e em suas rotinas, pois só através de novos comportamentos é que as mudanças ocorrem, apesar de ser um processo longo, que se mede em anos e não em meses. De acordo com as evidências, as mudanças na cultura organizacional são mais prováveis quando: i) a organização está enfrentando uma crise dramática; ii) há trocas de lideranças; iii) as organizações são jovens e pequenas e iv) a cultura é fraca (ROBBINS, 2002).

Johann (2004) defende que a cultura organizacional pode ser modificada de forma consciente e planejada desde que haja um gerenciamento efetivo. Para ele, as organizações devem ser revitalizadas por meio de um processo de revaloração cultural, que consiste em preservar o núcleo da cultura, revitalizando-o de quando em quando, ao mesmo tempo em que estimula a internalização de novos valores, atuando em duas dimensões: a) ressignificação dos valores culturais: apresentação de um preceito antigo a partir de outra ótica e com outra roupagem, como por exemplo: delegação de poderes x empowerment; b) obsolescência planejada de valores culturais: processo de análise e convencimento coletivo de que determinado valor não serve mais à empresa e, portanto, deverá ceder lugar a outro, como por exemplo: individualismo $\mathrm{x}$ trabalho em equipe.

O mesmo autor classifica os mecanismos que contribuem para a revaloração da cultura corporativa em: a) básicos: pesquisa-ação de clima organizacional, rituais corporativos, executivos e líderes como modelos sociais, comunicação/ações de endomarketing, padrões comportamentais com foco na interação com o cliente; e, b) avançados: gestão de talentos, matriz de indicadores/balanced scorecard, cidadania corporativa e reaprendizagem organizacional.

A cultura organizacional pode interferir no desempenho e/ou na satisfação dos funcionários, como demonstrado na ilustração 2: 
Fatores objetivos:

- Inovação e assunção de riscos

- Atenção aos detalhes

- Orientação para os resultados

- Orientação para as pessoas

- Orientação para as equipes

- Agressividade

- Estabilidade

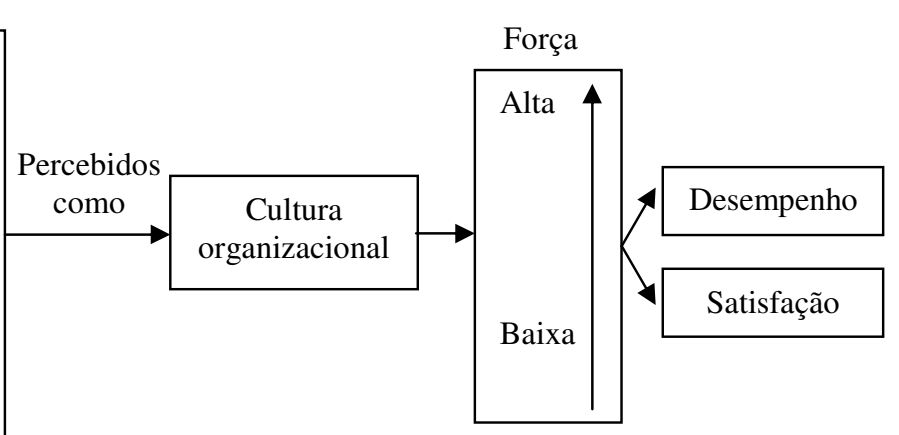

Ilustração 2 - Impacto da Cultura no Desempenho e na Satisfação dos Funcionários Fonte: Robbins (2002, p. 517). Transcrição total.

A ilustração 2 apresenta a cultura organizacional como uma variável interveniente, em que os funcionários têm uma percepção geral subjetiva da organização com base em fatores como o grau de tolerância aos riscos, a ênfase nas equipes e o apoio às pessoas. Essa percepção genérica torna-se a cultura da organização. Essas percepções favoráveis ou desfavoráveis afetam o desempenho e a satisfação dos funcionários, cujo impacto maior ocorrerá quanto mais forte for a cultura (ROBBINS, 2002).

Uma das principais implicações gerenciais da cultura organizacional se relaciona com as decisões sobre seleção de pessoal, pois a contratação de pessoas cujos valores não se ajustam aos da empresa, geralmente resulta em funcionários com pouca motivação e baixo comprometimento, tendo em vista que se sentem insatisfeitos com seu trabalho e com a organização.

Segundo Hofstede (2003, p. 26), existem diferenças nas culturas nacionais devido à sua origem histórica. A nacionalidade pode ser utilizada como referência sobre o estudo das diferenças culturais. $\mathrm{O}$ autor definiu cinco dimensões para análise da cultura organizacional : a) a distância hierárquica; b) o grau de individualismo (ou de coletivismo); c) o grau de masculinidade (ou de feminilidade); d) o controle da incerteza; e e) orientação a longo-prazo ou a curto-prazo.

$\mathrm{O}$ autor relata que em suas pesquisas identificou-se maior freqüência de grandes distâncias hierárquicas em antigas colônias, do que em antigos países colonizadores, existindo uma forte relação entre a riqueza nacional atual e o fato de ter sido um país colonizador ou colonizado nos últimos dois séculos. 
Os países com organizações que possuem uma grande distância hierárquica tendem a ser mais coletivistas e os países com uma pequena distância hierárquica tendem a ser mais individualistas. As exceções são a França e a Bélgica onde existe uma média hierarquia com um forte individualismo. Na Áustria e Israel encontra-se situação inversa, com uma pequena hierarquia associada a um individualismo médio e na Costa Rica observa-se uma hierarquia relativamente baixa associada a um forte coletivismo.

Os países mais femininos são a Suécia e a Noruega, onde se exprimem os mesmos valores de ternura e generosidade. Nos países mais masculinos, o Japão e a Áustria, homens e mulheres têm valores "duros" (masculinos) embora as diferenças entre eles fossem maior (HOFSTEDE, 2003, p. 103-104).

Em relação ao grau de controle da incerteza de um país, o mesmo autor diz que é o grau de inquietude dos seus habitantes face às situações desconhecidas ou incertas. Isso se exprime pelo estresse e a necessidade de previsibilidade: uma necessidade de regras, escritas ou não. Os países com maior controle foram Grécia, Portugal, Guatemala e Uruguai respectivamente. Os que apresentaram menor controle foram: Singapura, Jamaica, Dinamarca e Suécia. As culturas mais ansiosas tendem a ser mais expressivas, são os países onde as pessoas falam com as mãos, falam alto e mostram emoções.

A quinta dimensão de Hofstede (2003) é a orientação a longo-prazo ou a curto-prazo. Os cinco tigres asiáticos estão na visão de longo-prazo são China, Hong Kong, Tawain, Japão, Coréia do Sul, seguidos do Brasil. O autor explica uma relação com os ensinamentos de Confúcio na cultura de longo-prazo dos países orientais.

Nesse sentido, as culturas organizacionais e nacionais são de naturezas diferentes. Essas distinções se devem aos diversos papéis representados em cada uma pelas manifestações da cultura descritas pelos símbolos, heróis, rituais e valores, dos quais os três primeiros foram agrupados sob o nome de práticas.

O mesmo autor relata que as empresas expandem-se cada vez mais através de fusões e aquisições de outras organizações estrangeiras. As interações interculturais desempenham um papel considerável, pois as relações são entre as culturas nacionais e também as organizacionais. Os cinco métodos de expansão internacional são:

a) criação de novas filiais (a cultura da filial converte-se em uma combinação de elementos nacionais e os elementos da corporação); b) aquisição de uma empresa estrangeira (integra-se rapidamente a cultura da empresa estrangeira à cultura da antiga empresa e do país); c) fusão internacional (os parceiros têm praticamente tamanho e importância iguais, 
com uma liderança forte e carismática durante a fase de integração); d) empresa conjunta internacional (joint-venture) - com a criação de uma nova unidade com a concentração de recursos dos parceiros, transferindo parte da cultura destes; e) aliança estratégica internacional - método mais prudente de internacionalização, onde os parceiros decidem colaborar relativamente com um projeto específico, onde cada parceiro conhece muito melhor a cultura do outro que no caso de uma fusão simples, de acordo com Hofstede (2003).

Dessa forma, é relevante a afirmação de Tanure e Duarte (2006) no contexto da internacionalização da economia, onde são importantes os impactos que a cultura dos países e das organizações exercem nos negócios das empresas multinacionais.

Segundo os mesmos autores, cada organização tem sua própria cultura, pois tem suas características peculiares que as diferenciam das outras. O sistema de gestão brasileiro é caracterizado pela herança histórica do país, por raízes portuguesas e africanas. São quatro os traços da cultura brasileira: a concentração do poder; atitude de espectador; personalismo e tendência de evitar conflitos.

Tanure e Duarte (2006) fazem uma comparação entre o sistema de gestão brasileiro e o de outros países, considerando a cultura nacional e cultura organizacional. Afirmam que nas empresas brasileiras predomina-se a centralização de poder, que concentra nos líderes a tomada de decisões, as iniciativas e as soluções de problemas. Dessa forma, os liderados são espectadores, têm baixa autonomia e alto medo de errar, e isso os impede de usar a capacidade criativa, fenômeno chamado pelos autores de "lado sombra" das organizações brasileiras. O lado positivo, "lado sol", é a afetividade, hospitalidade e alta capacidade relacional das pessoas, que as torna mobilizáveis, gerando um comprometimento dos colaboradores com as metas da organização, sendo um diferencial competitivo.

Nesse mesmo sentido Hitt, Miller e Colella (2007) afirmam que gestores dos EUA lideram funcionários socializados em diferentes culturas, gerentes estrangeiros lideram funcionários norte-americanos e grupos de trabalho são compostos por pessoas de diferentes culturas que necessitam trabalhar em conjunto. Os líderes norte-americanos valorizam o individualismo, a participação na tomada de decisão, orientação para o futuro, estreita distância de poder e uma orientação para um alto nível de desempenho. Os líderes transacionais (valorizam recompensas) e não carismáticos são eficazes nesse tipo de organização.

Uma cultura que valoriza o coletivismo (o grupo mais importante que os indivíduos) ou apresente uma grande distância de poder, são compartilhados em países como Egito, 
Marrocos e Turquia. De acordo com Hitt, Miller e Colella (2007, p. 246), foi criado o projeto GLOBE (Global Leadership and Organizational Behavior Effectiveness) - liderança globalizada e eficácia do comportamento organzacional, onde as descobertas preliminares agrupam os países em conglomerados com histórias e valores em comum, como segue:

1) Conglomerado Anglo-Saxônico (Austrália, Canadá, Inglaterra, Irlanda, Nova Zelândia e África do Sul): o líder ideal demonstra influência carismática e inspiração incentivando ao mesmo tempo a participação. Os líderes são vistos como diplomatas, delegando autoridade e permitindo que todos tenham liberdade de se expressar.

2) Conglomerado Árabe (Egito, Marrocos, Turquia, Kuwait e Qatar): líderes ideais precisam equilibrar um conjunto paradoxal de expectativas. Espera-se que sejam carismáticos e poderosos, mas que não façam distinção entre si mesmo e as outras pessoas, e que tenham estilos modestos. É também esperado que os líderes detenham uma grande parcela do poder e que controlem e direcionem a maior parte das decisões e das ações.

3) Conglomerado Germânico (Áustria, Alemanha, Holanda, Suíça): o líder ideal é aquele que é carismático, fortemente orientado para equipes e participativo.

4) Conglomerado do Sul da Ásia (Índia, Indonésia, Irã, Malásia, Filipinas e Tailândia): o líder ideal é humanitário, participativo e carismático. Espera-se que os líderes sejam benevolentes, ao mesmo tempo mantendo uma forte posição de autoridade.

De acordo com os resultados das pesquisas do projeto GLOBE citado por Hitt, Miller e Colella (2007), a liderança carismática é considerada eficaz e desejável em todas as culturas. Os executivos-chefes precisam desenvolver a sensibilidade e a cultura necessária para que compreendam as diferenças nos requisitos para liderança entre as fronteiras nacionais e as culturas nacionais, contribuindo para forças de trabalho multinacionais altamente efetivas.

Nesse contexto, ganha destaque a gestão estratégica de pessoas nas organizações que administram sua cultura organizacional e líderes orientados para resultados.

\subsection{Gestão Estratégica de Pessoas}

Em relação à gestão estratégica de pessoas é necessária a compreensão dos conceitos de estratégia, estratégia competitiva, gestão estratégica, gestão estratégica de recursos humanos e o gestor ou estrategista.

Para Mintzberg, Ahlstrand e Lampel (2000), estratégia é um modelo ou plano que integra os objetivos, as políticas e as ações seqüenciais de uma organização de forma abrangente. Dentre os muitos conceitos de estratégia, um dos mais objetivos é o de Wright, Kroll e Parnell (2000), que a definem como "planos da alta administração para alcançar resultados consistentes com a missão e os objetivos gerais da organização”. 
Outro entendimento de estratégia é "a formulação das missões das organizações, objetivos, metas bem como de planos de ação para atingí-los, que explicitamente reconhece a competição e o impacto das forças do ambiente externo" (ANTHONY, PERREWÉ, KACMAR, 1996, p. 12).

Estratégia competitiva é "a busca de uma posição competitiva favorável em uma indústria, arena fundamental onde ocorre a concorrência” (PORTER, 1986, p.1-8). Essa estratégia visa estabelecer posição lucrativa e sustentável contra as forças que determinam a concorrência.

A gestão estratégica procura, em um enfoque amplo, proporcionar um ajuste compatível e contínuo entre a organização e o ambiente, pela tomada de decisões a pela execução de ações consistentes, viabilizando a capacidade competitiva da empresa de acordo com Wright, Kroll e Parnell (2000).

Para Ansoff (1990), o processo de gestão estratégica é um processo de três partes: o planejamento estratégico, o planejamento do potencial de gestão e a administração do processo geral de mudança estratégica. Para o desenvolvimento destes processos e promover interações positivas frente às mudanças das exigências e das oportunidades do mercado, o papel do gestor torna-se fundamental, exigindo-se do mesmo a criação de condições para a convivência equilibrada dentro da organização de comportamentos empreendedoriais (estratégico-descontínuos) e concorrenciais (operacional-incrementais).

A gestão estratégica é um processo complexo cuja essência é eminentemente social, afetando o bem estar das pessoas e da organização, envolvendo níveis diferentes e vários processos de pensamento da empresa e do ambiente, explorando ligações entre contexto, conteúdo e processo de mudança em um contínuo através do tempo.

Nesse sentido, é de fundamental importância o link entre a gestão estratégica e a gestão estratégica de pessoas para o alcance dos objetivos e metas organizacionais. Anthony, Perrewé e Kacmar (1996) e Albuquerque (1999, 2002) definem a gestão estratégica de pessoas como sendo: “a formulação, implementação e avaliação de resultados, de estratégias organizacionais voltadas para a obtenção de vantagens competitivas sustentáveis, baseadas no fator humano e na sua gestão".

A gestão estratégica de recursos humanos tem crescido em importância no cenário organizacional nos últimos quinze anos. Diversos estudos têm demonstrado a importância da gestão estratégica de pessoas para as organizações, bem como o papel do gestor de RH (ULRICH, 1998, 2005; ALBUQUERQUE, 1999, 2002). O papel da atuação da área de RH 
tem dois grandes eixos distintos: o operacional (rotinas trabalhistas, folha de pagamento, serviços internos e operacionais, sem vinculação com as políticas e estratégias organizacionais) e o estratégico - gestão estratégica de recursos humanos, visando a obtenção de resultados organizacionais e a integração das práticas operacionais aos objetivos da empresa. Portanto, o eixo estratégico busca a integração das práticas de $\mathrm{RH}$ com o processo de planejamento estratégico da empresa, visando o ajuste entre os planos organizacionais e os planos de RH.

Ainda nesta direção Wood Jr. (2000) e Marras (2000) discutem a evolução e práticas da gestão de pessoas no Brasil no século XX, onde apresentam cinco fases independentes que circundam o processo evolutivo da gestão de pessoas. Esta evolução representa todo o momento histórico, cultural, político e econômico vivenciado pela sociedade e conseqüentemente pelas organizações, o que é identificado no quadro 16.

Quadro 16 - Evolução e Práticas da Gestão de Pessoas no Brasil

\begin{tabular}{|c|c|c|c|c|c|}
\hline $\begin{array}{c}\text { Fase } \\
\text { Evolutiva }\end{array}$ & $\begin{array}{c}\text { Contábil ou } \\
\text { pré-jurídico } \\
\text { trabalhista }\end{array}$ & $\begin{array}{c}\text { Legal ou } \\
\text { burocrática }\end{array}$ & Tecnicista & $\begin{array}{l}\text { Administrativa } \\
\text { ou sistêmica }\end{array}$ & Estratégica \\
\hline $\begin{array}{l}\text { Período } \\
\text { aproximado de } \\
\text { abrangência }\end{array}$ & Antes de 1930 & 1930 a 1950 & 1950 a 1965 & 1965 a 1985 & 1985 a atual \\
\hline Características & $\begin{array}{l}\text { Inexistência de } \\
\text { legislação } \\
\text { trabalhista e do } \\
\text { departamento } \\
\text { de pessoal; } \\
\text { descentralizaçã } \\
\text { o das funções; } \\
\text { preocupação } \\
\text { com os custos } \\
\text { da organização; } \\
\text { proletariado } \\
\text { industrial com } \\
\text { fraco poder de } \\
\text { pressão. }\end{array}$ & $\begin{array}{l}\text { Advento da } \\
\text { legislação } \\
\text { trabalhista; } \\
\text { surgimento do } \\
\text { departamento } \\
\text { pessoal para } \\
\text { atender às } \\
\text { exigências legais } \\
\text { em decorrência } \\
\text { da era Getulista; } \\
\text { a administração } \\
\text { de pessoas era de } \\
\text { natureza legal, } \\
\text { disciplinadora, } \\
\text { punitiva e } \\
\text { paternalista. }\end{array}$ & $\begin{array}{l}\text { Implantação da } \\
\text { indústria } \\
\text { automobilística; } \\
\text { implementação dos } \\
\text { subsistemas de } \\
\text { RH; } \\
\text { preocupação com a } \\
\text { eficiência e o } \\
\text { desempenho; } \\
\text { modelo baseado no } \\
\text { modelo americano } \\
\text { da gestão de } \\
\text { pessoal; } \\
\text { início à } \\
\text { valorização dos } \\
\text { treinamentos, } \\
\text { desenvolvimento } \\
\text { de pessoal, cargos, } \\
\text { salários e } \\
\text { benefícios. }\end{array}$ & $\begin{array}{l}\text { Surgimento da } \\
\text { gerência de RH e } \\
\text { do responsável } \\
\text { pelas relações } \\
\text { industriais; } \\
\text { integração dos } \\
\text { enfoques } \\
\text { administrativos, } \\
\text { estruturalista e } \\
\text { comportamental; } \\
\text { marco histórico } \\
\text { nas relações entre } \\
\text { capital e } \\
\text { trabalho; } \\
\text { buscou-se } \\
\text { transferir a } \\
\text { ênfase em } \\
\text { procedimentos } \\
\text { burocráticos e } \\
\text { operacionais para } \\
\text { responsabilidade } \\
\text { s de ordem mais } \\
\text { humanísticas. }\end{array}$ & $\begin{array}{l}\text { Reformas } \\
\text { estruturais } \\
\text { profundas; } \\
\text { migração da } \\
\text { função de RH } \\
\text { para as áreas } \\
\text { operacionais; } \\
\text { surgimento do } \\
\text { movimento da } \\
\text { qualidade; } \\
\text { heterogeneidade; } \\
\text { programas de } \\
\text { planejamento } \\
\text { estratégico de } \\
\text { pessoas atrelado } \\
\text { ao planejamento } \\
\text { estratégico } \\
\text { central das } \\
\text { organizações; } \\
\text { preocupação a } \\
\text { longo prazo com } \\
\text { as pessoas; } \\
\text { RH como } \\
\text { consultoria } \\
\text { interna. }\end{array}$ \\
\hline $\begin{array}{l}\text { Formação } \\
\text { Predominante } \\
\text { do Profissional }\end{array}$ & Contadores & Advogados & Psicólogos & $\begin{array}{l}\text { Administradores } \\
\text { Sociais }\end{array}$ & $\begin{array}{l}\text { Profissional } \\
\text { diversificado/ } \\
\text { generalista }\end{array}$ \\
\hline
\end{tabular}




\begin{tabular}{|l|l|l|l|l|l|}
\hline $\begin{array}{l}\text { Nível de } \\
\text { influência }\end{array}$ & Operacional & Operacional & Tático & $\begin{array}{l}\text { Transição do } \\
\text { tático/estratégico }\end{array}$ & Estratégico \\
\hline $\begin{array}{l}\text { Concepções de } \\
\text { homem }\end{array}$ & Ser econômico & Ser econômico & Ser social & $\begin{array}{l}\text { Ser } \\
\text { organizacional }\end{array}$ & Ser integral \\
\hline
\end{tabular}

Fonte: Wood Jr. (2000, p.39). Transcrição integral.

Trata-se de um breve retrospecto acerca da evolução do conceito de gestão de pessoas e a forma como a abordagem estratégica está inserida, pois a literatura é muito rica em conteúdos relacionados a esta temática.

Observa-se o seguinte ponto: embora as fases estejam delimitadas por um período aproximado de abrangência, encontram-se nos dias atuais organizações vivenciando paradigmas na gestão de pessoas em todas as fases, ou seja, algumas organizações continuam considerando as pessoas como trabalhadores exclusivamente sob o enfoque contábil e outras estão extremamente preocupadas com as questões meramente legais.

A gestão de pessoas precisa ter como base de trabalho a missão e visão organizacional acompanhando a evolução das empresas e um dos pontos mais importantes é a sua ligação com as estratégias organizacionais. As ações que envolvem a gestão de pessoas não devem ser vistas como segmentos isolados, elas precisam estar combinadas e sempre antecedendo as estratégias organizacionais.

Os novos horizontes dos profissionais de recursos humanos estão inseridos em um cenário de grandes turbulências provocadas pelas mudanças econômicas, políticas, sociais, culturais, tecnológicas, organizacionais etc. É necessário mais do que novas ferramentas, mas uma moderna forma de encarar e conduzir a relação com o pessoal e com o negócio da empresa. Isso será traduzido em novas oportunidades para os administradores de recursos humanos que estão preocupados em agregar valor à empresa e a seus colaboradores, participando ativamente da melhoria da qualidade de vida das pessoas e da sociedade.

Para Ulrich e Wayne (2005, p. 153),

O processo envolve seis etapas: 1) identificar a unidade organizacional e organizar a oficina; 2) dar prioridade aos trendes no ambiente de negócio; 3) especificar as fontes da vantagem competitiva e das medidas para cada fonte de vantagem competitiva; 4) definir as potencialidades culturais desejadas junto com as expressões destas potencialidades culturais; 5) identificar as práticas de RH que terão maior influência na criação e sustentação da cultura desejada; 6) desenvolver um plano de implementação total. ${ }^{10}$ (tradução do pesquisador)

\footnotetext{
10 "The process involves six steps:

1) Identify the organizational unit and organize the workshop;

2) Prioritize the trendes in the business environment;

3) Specify the sources of competitive advantage and the measurements for each source of competitive advantage;
} 
Os autores afirmam que deve ser um processo com fases interdependentes, onde a cultura organizacional e as vantagens competitivas devem ser identificadas e administradas visando o atendimento das estratégias organizacionais e de recursos humanos.

Para a efetividade da gestão estratégica de pessoas é necessário o planejamento estratégico de recursos humanos. Carvalho e Serafim (2001) entendem planejamento estratégico de RH como processo continuado nas tomadas das decisões envolvendo gestão de pessoal, sendo flexível e dinâmico diante das adversidades do cotidiano da empresa. Para tanto, é necessário que haja um sistema organizacional aberto e interdependente, onde o RH dita políticas com a finalidade de atingir objetivos estratégicos gerais da organização.

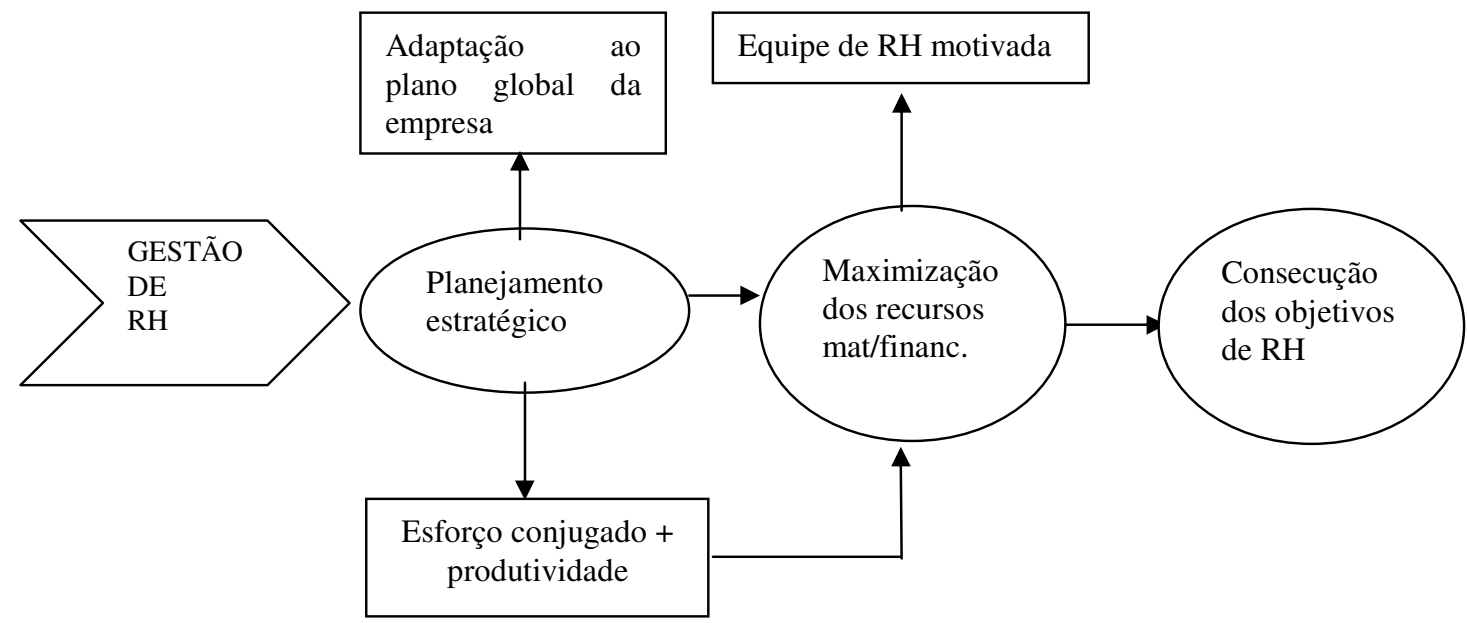

Ilustração 3 - Fluxo do conceito dinâmico de Planejamento Estratégico de RH Fonte: Carvalho e Serafim (2001, p. 15). Transcrição integral.

A gestão de pessoas nas organizações está cada vez mais importante devido principalmente às mudanças nas últimas duas décadas como: a globalização da economia; a introdução de novas tecnologias; a crescente valorização do conhecimento (intangível); acesso à informação e à educação formal; as fusões, aquisições e privatizações; as alterações demográficas; responsabilidade sócio-ambiental e desenvolvimento sustentável; a crescente valorização dos princípios éticos; as mudanças na legislação trabalhista e flexibilização do trabalho e a consolidação da democracia com as transformações sociais.

4) Define the desired cultural capabilities together with the behavioral expressions of these cultural capabilities;

5) Identify the HR practices the will have greatest influence on creating and sustaining the desired culture;

6) Develop an overall implementation plan." 
Segundo Albuquerque (1999, 2002), a estratégia de Recursos Humanos deve seguir as etapas do processo de formulação e implementação da estratégia corporativa. Dessa forma, é necessária a sua integração com a estratégia da empresa.

Anthony, Perrewé e Kacmar (1996) apresentam algumas características da administração estratégica de recursos humanos: reconhece os impactos do ambiente externo e da competição e dinâmica do mercado de trabalho; apresenta foco no longo prazo; enfatiza a escolha e a tomada de decisão; considera todas as pessoas da empresa, não só os executivos; deve estar integrada com a estratégia corporativa.

As principais etapas da estratégia de RH são: desenvolvimento da compreensão e do comprometimento com a visão do negócio; missão da ARH; análise do ambiente de RH; análise dos recursos humanos; definição de políticas de RH; elementos estratégicos críticos de RH; estratégias de RH para inclusão no plano estratégico da empresa. É necessário em todas as etapas o feedback dos resultados retroalimentando o processo, conforme apresentado na ilustração 4.
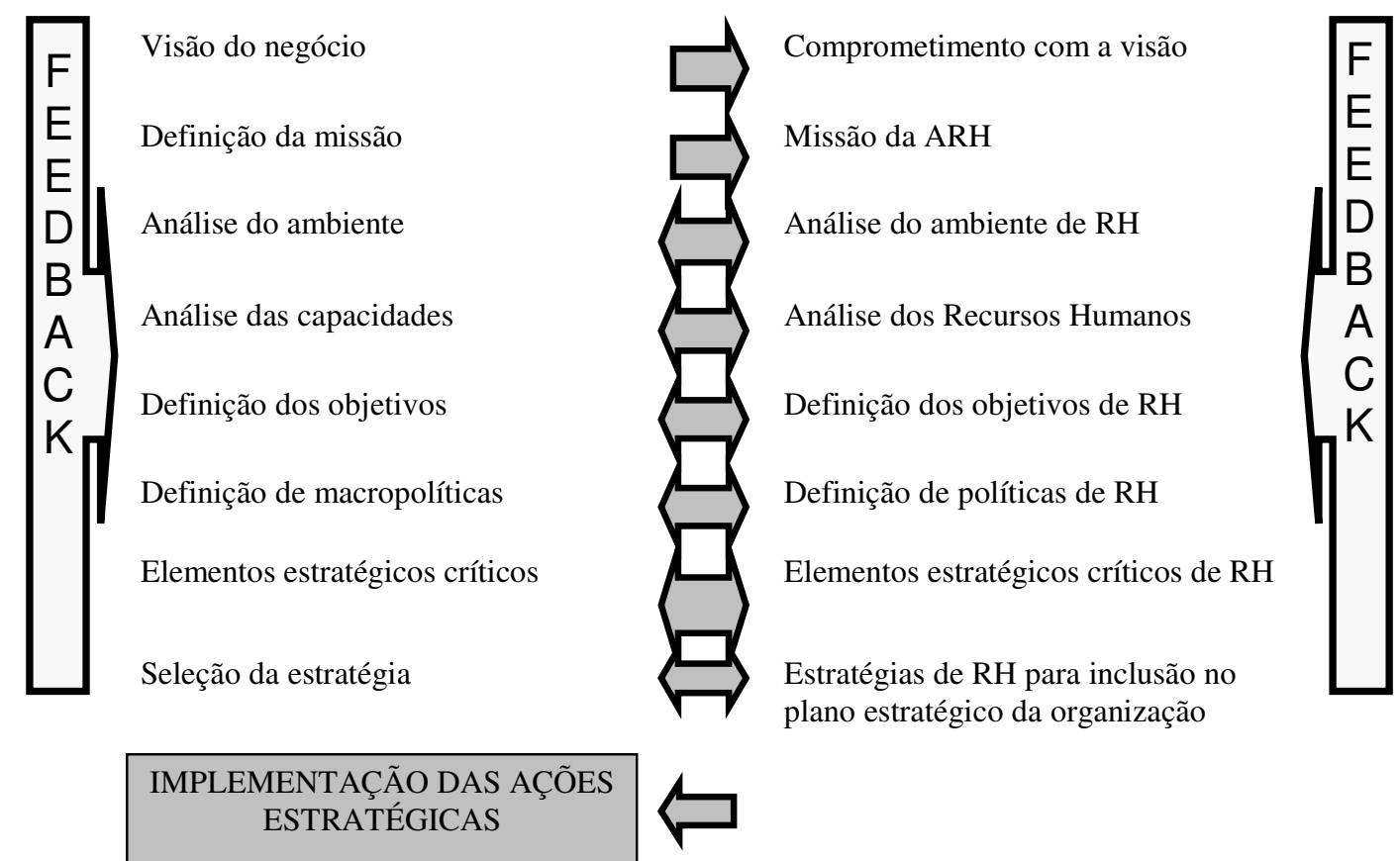

Ilustração 4 - Integração da Estratégia de RH na estratégia da empresa: etapas do processo de formulação

Fonte: Albuquerque (2002, p. 41). Transcrição integral. 
Com o desenvolvimento da compreensão e do comprometimento com a visão do negócio, faz-se necessário a definição da missão de $\mathrm{RH}$, com um profundo estudo do ambiente (interno e externo) e da própria realidade do papel desempenhado pela sua função de RH na empresa. Para isso é necessário que o RH levante os seus pontos fracos e fortes e as ameaças e oportunidades dentro e fora da organização. Albuquerque (2002) divide esta etapa em duas partes, onde na primeira verifica-se a análise do ambiente organizacional e na segunda trata-se da análise das capacidades internas.

A análise das capacidades internas tem por objetivo avaliar os recursos organizacionais, identificando as forças e as fraquezas da organização no processo de formulação estratégica (ALBUQUERQUE, 2002). Verifica-se que as pessoas são tidas como a base para a obtenção das capacidades internas. Para o autor, a formulação estratégica de gestão de pessoas, evidentemente, interessa aprofundar os aspectos relativos às dimensões humanas, ou seja, a cultura e as pessoas, e como a interação das pessoas com a estrutura e com o sistema pode contribuir para a consecução dos objetivos estratégicos da organização.

É relevante destacar que existem duas posições sobre o ser humano no trabalho como proposto por Anthony, Perrewé e Kacmar (1996) e Albuquerque (2002):

a) Concepção Econômica (Tradicional): ser humano como fator de produção, como mais um recurso e como número;

b) Concepção Transformada (Comprometimento): ser humano como pessoa, como parceiro efetivo na busca dos objetivos organizacionais e de agregação de valor à sociedade.

Essas visões devem ser consideradas e afetam profundamente a forma da realização da gestão estratégica de pessoas nas organizações. O quadro 17 demonstra uma síntese dessas concepções. 


\begin{tabular}{|c|c|c|}
\hline MODELO & $\begin{array}{l}\text { ESTRATÉGIA DE CONTROLE } \\
\text { (CONCEPÇÃO } \\
\text { TRADICIONAL) }\end{array}$ & $\begin{array}{c}\text { ESTRATÉGIA DE } \\
\text { COMPROMETIMENTO } \\
\text { (CONCEPÇÃO } \\
\text { TRANSFORMADA) }\end{array}$ \\
\hline $\begin{array}{l}\text { ESTRUTURA } \\
\text { ORGANIZACIONAL }\end{array}$ & $\begin{array}{l}\text { Altamente hierarquizada, separação } \\
\text { "quem pensa" e "quem faz" }\end{array}$ & $\begin{array}{l}\text { Redução de níveis hierárquicos e de } \\
\text { chefias intermediárias, junção do } \\
\text { fazer e do pensar - empowerment }\end{array}$ \\
\hline ORGANIZAÇÃO DO TRABALHO & $\begin{array}{l}\text { Trabalho muito especializado, } \\
\text { gerando monotonia e frustrações }\end{array}$ & $\begin{array}{l}\text { Trabalho enriquecido, gerando } \\
\text { desafios }\end{array}$ \\
\hline REALIZAÇÃO DO TRABALHO & Individual & Em grupo \\
\hline SISTEMA DE CONTROLE & $\begin{array}{l}\text { Ênfase em controles explícitos do } \\
\text { trabalho }\end{array}$ & $\begin{array}{l}\text { Ênfase no controle implícito pelo } \\
\text { grupo }\end{array}$ \\
\hline $\begin{array}{l}\text { RELAÇÕES DE TRABALHO } \\
\text { Política de emprego }\end{array}$ & $\begin{array}{l}\text { Foco no cargo, emprego a curto } \\
\text { prazo }\end{array}$ & $\begin{array}{l}\text { Foco no encarreiramento flexível, } \\
\text { emprego a longo prazo }\end{array}$ \\
\hline $\begin{array}{l}\text { NÍVEL DE EDUCAÇÃO E } \\
\text { FORMAÇÃO REQUERIDO }\end{array}$ & $\begin{array}{l}\text { Baixo, trabalho automatizado e } \\
\text { especializado }\end{array}$ & $\begin{array}{l}\text { Alto, trabalho enriquecido e } \\
\text { intensivo em tecnologia }\end{array}$ \\
\hline $\begin{array}{l}\text { RELAÇÕES EMPREGADOR- } \\
\text { EMPREGADO }\end{array}$ & Independência & Interdependência, confiança mútua \\
\hline RELAÇÕES COM SINDICATOS & $\begin{array}{l}\text { Confronto baseado na divergência } \\
\text { de interesses }\end{array}$ & $\begin{array}{l}\text { Diálogo, busca da convergência de } \\
\text { interesses }\end{array}$ \\
\hline \multirow[t]{2}{*}{$\begin{array}{l}\text { PARTICIPAÇÃO DOS } \\
\text { EMPREGADOS NAS DECISÕES }\end{array}$} & $\begin{array}{l}\text { Baixa, decisões tomadas de cima } \\
\text { para baixo }\end{array}$ & Alta, decisões tomadas em grupo \\
\hline & \multicolumn{2}{|l|}{ Políticas de Recursos Humanos } \\
\hline CONTRATAÇÃO & $\begin{array}{l}\text { Contrata para um cargo ou para um } \\
\text { conjunto especializado de cargos }\end{array}$ & $\begin{array}{l}\text { Contrata para uma carreira longa na } \\
\text { empresa }\end{array}$ \\
\hline TREINAMENTO & $\begin{array}{l}\text { Visa o aumento do desempenho na } \\
\text { função atual }\end{array}$ & $\begin{array}{l}\text { Visa preparar o empregado para } \\
\text { futuras funções }\end{array}$ \\
\hline CARREIRA & $\begin{array}{l}\text { Carreiras rígidas e especializadas, } \\
\text { de pequeno horizonte e amarradas } \\
\text { na estrutura de cargos }\end{array}$ & $\begin{array}{l}\text { Carreiras flexíveis. De longo } \\
\text { alcance, com permeabilidade entre } \\
\text { diferentes carreiras }\end{array}$ \\
\hline SALARIAL & $\begin{array}{l}\text { Focada na estrutura de cargos, com } \\
\text { alto grau de diferenciação salarial } \\
\text { entre eles }\end{array}$ & $\begin{array}{l}\text { Focada na posição de carreira e no } \\
\text { desempenho, com baixa } \\
\text { diferenciação entre eles }\end{array}$ \\
\hline INCENTIVOS & Uso de incentivos individuais & $\begin{array}{l}\text { Foco nos incentivos grupais } \\
\text { vinculados a resultados empresariais }\end{array}$ \\
\hline
\end{tabular}

Fonte: Albuquerque (1999 e 2002, p. 39). Transcrição integral.

A estrutura organizacional na concepção tradicional caracteriza-se por apresentar uma alta hierarquização, onde o pensar e o fazer ocupam posições distintas entre si. A produção é em massa e a organização do trabalho apóia-se na especialização, o trabalho é realizado individualmente e o sistema de controle do trabalho é enfatizado de forma explícita. A concepção transformada, por sua vez, apresenta um sistema onde os níveis hierárquicos são reduzidos, incentiva-se a redução de chefias intermediárias e busca uma interação entre o pensar e o fazer. A produção organiza-se de forma mais flexível, exigindo menos especialização e conseqüentemente um enriquecimento do trabalho e em grupo, onde o controle se dá implicitamente pelo próprio grupo. 
O nível de educação e formação requerido na concepção tradicional era mínimo, suficiente para lidar com um trabalho automatizado e especializado. A política de emprego focada no cargo estimula um emprego a curto prazo. Na concepção transformada, o nível de formação é alto, coerente com as demandas necessárias para a realização de um trabalho enriquecido e intensivo em tecnologia; o foco está no encarreiramento flexível, enfatizado em um emprego a longo prazo. As relações de trabalho, na forma controlada eram de independência para quem empregava, visto que o ser humano era facilmente substituído, o que na forma comprometida se dá de outra maneira, pois passa a existir uma relação de confiança mútua e de interdependência. A participação dos empregados nas decisões da organização é alta e as relações sindicais buscam o diálogo e a convergência de interesses na estratégia de comprometimento, enquanto uma baixa participação nas decisões e um sindicato mais voltado à divergência de interesses são observados na concepção tradicional (ALBUQUERQUE, 1999, 2002).

As políticas de Recursos Humanos na antiga concepção, orientam-se na estrutura de cargos vigentes, com foco de curto prazo e carreiras rígidas. Na nova concepção, o foco está na valorização dos talentos na empresa e na criação de condições favoráveis à motivação individual; investe-se na construção da carreira, sendo esta flexível e passível de mudança, além de oferecer incentivos atrelados a resultados (ALBUQUERQUE, 1999, 2002).

As características da concepção transformada envolvem as principais políticas de gestão de pessoas que as organizações devem possuir: contratação de pessoal (perfil desejável, recrutamento e seleção para uma visão de carreira), treinamento e desenvolvimento (de forma ampla e abrangente), carreira (flexível, longo prazo e ampla), progressão salarial (baseada em competências, habilidades e entregas de resultados), incentivos (grupais, simbólicos e reconhecimento).

Albuquerque (2002) enfatiza a importância da estratégia de recursos humanos ser baseada na concepção transformada ou de comprometimento, ao invés da concepção tradicional ou de controle, considerando as pessoas como parceiros da organização, como um investimento para conseguir melhores resultados empresariais. Afirma também que a participação no processo de formulação estratégica é condição fundamental para a obtenção do comprometimento das pessoas sobre os objetivos organizacionais.

Nesse sentido, são necessárias diversas competências para os profissionais de recursos humanos para o desenvolvimento de lideranças orientadas para resultados e também para o planejamento e implementação da gestão estratégica de pessoas na concepção transformada. 
Diversos estudos foram realizados pelos pesquisadores da Human Resource Management (SHRM) e da Michigan University dos Estados Unidos sobre as competências requeridas dos profissionais de Recursos Humanos. Os autores Becker, Huselid e Ulrich (2001) relatam os principais resultados dessas pesquisas a seguir.

1) Competência de Recursos Humanos: a competência refere-se às características de um indivíduo, em termos de conhecimentos, habilidades, capacidades e personalidade, que afetam diretamente o respectivo desempenho no trabalho.

Em 1992 e 1993 esses autores pesquisaram empresas globais, envolvendo mais de 5.000 participantes. Os resultados salientaram o novo papel estratégico de RH na virada do século XX e início do século XXI. Especificamente, os pesquisadores observaram um aumento drástico no tempo que os profissionais de $\mathrm{RH}$ se dedicavam a assuntos estratégicos e uma diminuição relativa ao tempo alocado a questões mais tradicionais. A pesquisa mais recente entrevistou mais 5.000 profissionais entre 1997 e 1998. Estes resultados revelaram uma profissão em contínua mutação, assumindo cada vez mais um papel estratégico na vida organizacional. Surgindo mais duas competências que, juntamente com as três anteriores, são explicitadas a seguir (BECKER, HUSELID, ULRICH, 2001):

2) Conhecimento do Negócio: os profissionais de $\mathrm{RH}$ agregam valor à organização quando compreendem o funcionamento do negócio. Essa compreensão lhes permite adaptar a área de $\mathrm{RH}$ e as atividades organizacionais às mudanças nas condições empresariais. Apenas conhecendo os recursos financeiros, estratégicos, tecnológicos e organizacionais da empresa os profissionais de RH serão capazes de desempenhar um papel importante em qualquer discussão estratégica.

3) Fornecimento de Práticas de RH: os profissionais de RH devem ser experts nas respectivas especialidades. Conhecer e ser capaz de fornecer práticas inovadoras de $\mathrm{RH}$, reforça a credibilidade desses profissionais e assegura-lhes o respeito do restante da organização.

4) Gestão da Mudança: as mudanças organizacionais necessárias à competição de mercado devem ser impulsionadas pelos profissionais de RH. Nesse sentido, são necessárias as seguintes capacidades: diagnosticar problemas, cultivar relacionamentos com os clientes, articular a visão da empresa, definir a agenda de liderança, resolver problemas, implementar metas. Essa competência envolve conhecimento (do processo de mudança), habilidades (como agente da mudança) e capacidades essenciais (de promover a mudança) para promover o lado humano da organização. 
5) Gestão da Cultura: as empresas com culturas "fortes" (medida pela extensão em que os empregados compartilham os valores da organização) tendem a atingir níveis de desempenho mais elevados. Os profissionais de RH precisam compreender que eles são os "guardiões da cultura" e que seu impacto vai bem além das fronteiras funcionais.

6) Credibilidade Pessoal: seria descrita como a base rochosa em que se apóiam os outros pilares (quatro competências anteriores). As pesquisas realizadas constataram que os profissionais de RH bem-sucedidos eram tidos como dignos de crédito tanto dentro como fora da função. Esse atributo envolve três dimensões: i) que os profissionais "vivam" os valores da empresa e sejam os "guardiões da cultura" da organização. ii) os profissionais ganham credibilidade quando seu relacionamento com os colegas baseia-se na confiança recíproca. iii) conquistam o respeito dos colegas quando agem com "firmeza", ou seja, sustentar sua opinião com fatos, apresentar idéias e soluções espontâneas, e estimular o debate sobre temas cruciais.

São múltiplos papéis que devem ser desempenhados pelos profissionais de recursos humanos para a efetiva gestão de recursos humanos. De acordo com Ulrich (1998), demonstra-se no quadro 18 a definição dos papéis, resultado, metáfora e atividade.

Quadro 18 - Definição dos Papéis de RH

\begin{tabular}{|l|l|l|l|}
\hline \multicolumn{1}{|c|}{ Papel/Função } & \multicolumn{1}{c|}{ Resultado } & \multicolumn{1}{c|}{ Metáfora } & \multicolumn{1}{c|}{ Atividade } \\
\hline $\begin{array}{l}\text { Adm. de Estratégias de } \\
\text { RH }\end{array}$ & Execução da estratégia & Parceiro Estratégico & $\begin{array}{l}\text { Ajuste das estratégias de } \\
\text { RH à estratégia } \\
\text { empresarial. Diag. Org. }\end{array}$ \\
\hline $\begin{array}{l}\text { Adm. da Infra-Estrutura } \\
\text { da Empresa }\end{array}$ & $\begin{array}{l}\text { Construção de uma infra- } \\
\text { estrutura eficiente }\end{array}$ & $\begin{array}{l}\text { Especialista } \\
\text { Administrativo }\end{array}$ & $\begin{array}{l}\text { Reengenharia de } \\
\text { processos de organiz. } \\
\text { Serviços em comum }\end{array}$ \\
\hline $\begin{array}{l}\text { Adm. da Contribuição } \\
\text { dos Funcionários }\end{array}$ & $\begin{array}{l}\text { Aumento do envolvimento } \\
\text { e capacidade dos } \\
\text { funcionários }\end{array}$ & $\begin{array}{l}\text { Defensor dos } \\
\text { Funcionários }\end{array}$ & $\begin{array}{l}\text { Ouvir e responder aos } \\
\text { funcionários: prover } \\
\text { recursos aos funcionários }\end{array}$ \\
\hline $\begin{array}{l}\text { Adm. da Transformação } \\
\text { e da Mudança }\end{array}$ & $\begin{array}{l}\text { Criação de uma } \\
\text { organização renovada }\end{array}$ & Agente de Mudanças & $\begin{array}{l}\text { Gerir a transformação e a } \\
\text { mudança: assegurar } \\
\text { capacidade para mudança }\end{array}$ \\
\hline
\end{tabular}

Fonte: Ulrich (1998, p. 41). Transcrição integral.

O papel de Administrador de Estratégias de RH é de fundamental importância, pois visa o alinhamento dos sistemas de RH operacionais à estratégia da organização. $\mathrm{O}$ autor afirma que novos papéis terão de ser definidos para os profissionais da área de $\mathrm{RH}$; os mesmos deverão ser múltiplos visando os objetivos organizacionais.

Segundo Ulrich (1998, p. 41), para cumprir o seu papel de Parceiro Estratégico, deve:

[...] concentrar-se no alinhamento das estratégias e práticas de recursos humanos às estratégias e práticas da empresa de uma maneira geral, ou seja, as estratégias empresariais devem ser prioridade no departamento de gestão de pessoas. Os Parceiros Estratégicos participam ativamente na definição da estratégia empresarial, 
identificam e concebem práticas de recursos humanos que se ajustem às estratégias organizacionais e fazem com que ela aconteça efetivamente. Assim, o profissional de recursos humanos auxilia na implantação e aceitação das mudanças, pois através de suas ações reduz o tempo entre a concepção e a execução da estratégia. Garante também a satisfação do cliente porque as estratégias, em forma de políticas e práticas, focalizaram o atendimento ao cliente. E obtém desempenho financeiro através da execução eficaz das estratégias estabelecidas.

Os novos papéis de Recursos Humanos apresentam significativas dimensões estratégicas para as organizações e para seus colaboradores. O quadro 19 a seguir, demonstra a evolução do pensamento e os papéis de RH, citado por Ulrich (2005).

\begin{tabular}{|c|c|c|}
\hline \multicolumn{3}{|c|}{ Quadro 19 - Evolução dos Papéis de RH - década de 1990 e 2000} \\
\hline Anos 1990 & Anos 2000 & Evolução do Pensamento \\
\hline $\begin{array}{l}\text { Defensor dos } \\
\text { Funcionários }\end{array}$ & $\begin{array}{l}\text { Advogado do } \\
\text { empregado. } \\
\text { Desenvolvedor do } \\
\text { capital humano. }\end{array}$ & $\begin{array}{l}\text { Os funcionários são cada vez mais críticos ao sucesso das } \\
\text { organizações. Foco no Advogado do empregado de hoje. O } \\
\text { desenvolvedor do Capital Humano focaliza em como os } \\
\text { empregados se preparam para o futuro. }\end{array}$ \\
\hline $\begin{array}{l}\text { Especialista } \\
\text { Administrativo }\end{array}$ & Perito funcional & $\begin{array}{l}\text { Práticas de RH são centrais para o valor de RH. Algumas } \\
\text { práticas de RH são entregues com a eficiência administrativa } \\
\text { (tal como a tecnologia)e outras com as políticas, menus, e as } \\
\text { intervenções, expandindo o papel "perito" funcional. }\end{array}$ \\
\hline $\begin{array}{l}\text { Agente de } \\
\text { Mudanças }\end{array}$ & Sócio Estratégico & $\begin{array}{l}\text { Ser um sócio estratégico tem dimensões múltiplas: especialista } \\
\text { administrativo, agente de mudanças, gerente de conhecimento e } \\
\text { consultor. Ser um agente da mudança representa somente uma } \\
\text { parte do papel estratégico do sócio. }\end{array}$ \\
\hline \multirow[t]{2}{*}{$\begin{array}{l}\text { Parceiro } \\
\text { Estratégico }\end{array}$} & Sócio Estratégico & Idem ao acima. \\
\hline & Líder & $\begin{array}{l}\text { A soma da liderança dos quatro papéis é igual, mas um líder de } \\
\text { RH tem também implicações para conduzir a função RH, } \\
\text { colaborando com outras funções, assegurar a governança } \\
\text { corporativa e monitorar a comunidade de RH. }\end{array}$ \\
\hline
\end{tabular}

Fonte: Ulrich, D.; Wayne, B. (2005, p. 201). Tradução do pesquisador.

Ulrich e Wayne (2005, p. 215) trazem um exemplo interessante das implicações do desenvolvimento das lideranças de RH onde:

A liderança começa do início, assim os líderes de RH devem conduzir e avaliar a sua própria função. E é fácil errar. Por exemplo, em uma grande companhia, o RH dirigiu um programa de desenvolvimento de duas semanas de liderança, no qual se gastou alguns dias em cada dimensão dos negócios: finanças, marketing, tecnologia, globalização e qualidade, e três horas de RH no sábado pela manhã. A mensagem era óbvia: nem mesmo os profissionais de RH consideram RH importante. Quando confrontado com esta observação, o organizador disse que não queria impor o RH nos líderes de negócios. Isso significa que ele não via RH como parte central à equação do negócio; ele não estava conduzindo uma perspectiva de potencialização. Os líderes nos negócios compartilham a tendência humana natural de aprender mais com o que vêem do que com o que ouvem, assim é essencial estabelecer um bom exemplo. (tradução do pesquisador) ${ }^{11}$

\footnotetext{
11 "Leadership begins at home, so HR leaders must lead and value their own function before anyone else will listen to them. And it's easy to go wrong. For example, in one large company, HR directed a two-week leadership development program that spent a few days on each major business dimension-finance, marketing,
} 
A definição das prioridades para as competências também foi analisada pelos pesquisadores da Michigan University. A pesquisa indicou que o papel de cada uma varia de menos para mais importante, na seguinte ordem: conhecimento do negócio, domínio das práticas de RH, gestão da cultura, orquestração da mudança e demonstração de credibilidade pessoal (BECKER, HUSELID, ULRICH, 2001).

As competências do gestor de pessoas são necessárias e importantes para o desenvolvimento da liderança orientada para resultados; por outro lado é relevante o entendimento de algumas responsabilidades pela estratégia da organização e da gestão de pessoas. Os autores ressaltam também que não existe somente confusão nos conceitos e enfoques sobre a estratégia, mas também sobre quem ou qual papel recai a responsabilidade maior pela formulação e execução estratégicas. Dentre estes nomes, dois grupos se destacam: por um lado, o dos gerentes (managers), englobando aqui os executivos, diretores, administradores; e de outro, os líderes (leaders), composto também pelos comandantes, chefes e empreendedores. Para Zaleznik (2004), a diferença fundamental entre estes dois grupos está na personalidade: enquanto gerentes enfatizam a racionalidade e o controle, canalizando suas energias para metas, recursos, estruturas organizacionais ou pessoas, procurando soluções para os problemas que surgem, os líderes apresentam abordagens abertas, projetando idéias e imagens que motivem outras pessoas, garantindo a imaginação e a criatividade na definição dos rumos da corporação.

Os gerentes e líderes apresentam diversas características culturais, de formação, de experiências, de concepção não coincidentes (ZALEZNIK, 2004):

(a) quanto à personalidade: gerentes são racionais e controladores, procurando assegurar a competência e o equilíbrio de poder entre grupos potencialmente contrários; líderes são emocionais e aceitam riscos, sendo muitas vezes caracterizados por adjetivos derivados das sensações que provocam;

(b) quanto às atitudes frente a metas: os gerentes tendem a adotar uma atitude impessoal, até passiva, em relação a metas - metas gerenciais surgem da necessidade e não do desejo, as quais estão entremeadas na história e na cultura da organização; os líderes

technology, globalization, and quality and three hours on HR on Saturday morning. The message was obvious: even HR professionals don't think HR matters much. When confronted with this observation, the organizer said essentially that he did not want to impose HR on business leaders. That meant he did not see HR as central to the business equation; he was not leading from an empowered HR perspective. Business leaders share the natural human tendency to learn more from what they see than from what they hear, so it's essential to set a good example." 
raciocinam sobre suas metas de forma ativa e não reativa, moldam idéias em vez de reagir a elas, adotando uma atitude pessoal;

(c) quanto à concepção de trabalho: para os gerentes, o trabalho é um processo que torna possível pessoas e idéias interagirem definindo estratégias e tomando decisões, sua meta é deslocar o equilíbrio de poder no sentido de soluções intermediárias aceitáveis pelas diversas partes do conflito - limitar as opções; para os líderes, o trabalho é um exercício de projeção de idéias em imagens que empolguem outros, com fim de criar novas alternativas e opções de ação;

(d) quanto às relações com os outros: o gerente prefere trabalhar em grupo, conciliando diferenças, buscando concessões e definindo o equilíbrio de poder, muitas vezes sendo caracterizado como alguém impenetrável, distante e manipulador - usa sinais para comunicar-se; o líder mantém-se emocionalmente próximo, dando importância às idéias e reagindo de forma mais intuitiva e prática - utiliza mensagens diretas;

(e) quanto ao senso próprio: gerentes reforçam sua auto-estima ao perpetuar e fortalecer as instituições existentes, buscando harmonia entre os ideais de dever e de responsabilidade; líderes são pessoas que se sentem deslocadas do ambiente, sua noção de si mesmo não depende da adesão a um determinado grupo;

(f) quanto à sua origem: gerentes são desenvolvidos através da socialização, que prepara os indivíduos para dirigir instituições e manter o equilíbrio existente nas relações sociais; líderes surgem através da maestria pessoal, que impulsiona um indivíduo a lutar por mudanças psicológicas e sociais;

(g) quanto ao foco de atenção: gerentes mantêm atenção em como executar as coisas; líderes dão destaque ao significado dos eventos e das decisões entre os envolvidos.

Para Bennis (2001), o trabalho do líder muda com a sua idade no cargo e cada fase da liderança traz novas crises e desafios angustiantes, tornando crucial para a manutenção da tomada ágil de decisões e sua capacidade de adaptar-se.

Para o efetivo alinhamento entre a gestão estratégica de pessoas com visão transformada e a estratégia da organização, é necessário o entendimento da evolução das estratégias organizacionais e as escolas de estratégia.

O Quadro 20 demonstra uma síntese das escolas de estratégia, o tipo de estratégia dominante, os agentes da estratégia e o tipo de liderança adotado. 
Quadro 20 - As Escolas de Estratégia, Tipo de Estratégias, Agentes e Liderança

\begin{tabular}{|c|c|c|c|}
\hline Escola/Grupo & Estratégia & Agentes & Liderança \\
\hline $\begin{array}{l}\text { Desenho } \\
\text { (Prescritiva) }\end{array}$ & $\begin{array}{l}\text { Processo de concepção, consciente e deliberado, } \\
\text { adaptando-se forças e fraquezas internas e ameaças } \\
\text { e oportunidades externas, formulando estratégias } \\
\text { claras, simples e únicas. }\end{array}$ & $\begin{array}{l}\text { Executivo } \\
\text { principal } \\
\text { (como } \\
\text { arquiteto) } \\
\end{array}$ & $\begin{array}{l}\text { Dominante, } \\
\text { arbitrária }\end{array}$ \\
\hline $\begin{array}{l}\text { Planejamento } \\
\text { (Prescritiva) }\end{array}$ & $\begin{array}{l}\text { Processo formal, não apenas cerebral mas também } \\
\text { formal, passivo de decomposição em etapas } \\
\text { distintas, delineadas por passos claros e sustentadas } \\
\text { por técnicas. }\end{array}$ & Planejadores & $\begin{array}{l}\text { Sensível e } \\
\text { procedimentos }\end{array}$ \\
\hline $\begin{array}{l}\text { Posicionamento } \\
\text { (Prescritiva) }\end{array}$ & $\begin{array}{l}\text { Processo analítico, compondo posições genéricas, } \\
\text { selecionadas através de análises formalizadas de } \\
\text { conjunturas industriais. }\end{array}$ & Analistas & $\begin{array}{l}\text { Sensível à } \\
\text { análise }\end{array}$ \\
\hline $\begin{array}{l}\text { Empreendedora } \\
\text { (Descritiva) }\end{array}$ & $\begin{array}{l}\text { Processo visionário centrado no executivo do topo e } \\
\text { baseado na intuição, visões e perspectivas } \\
\text { alargadas. }\end{array}$ & Líder & $\begin{array}{l}\text { Dominante, } \\
\text { intuitiva }\end{array}$ \\
\hline $\begin{array}{l}\text { Cognitiva } \\
\text { (Descritiva) }\end{array}$ & $\begin{array}{l}\text { Processo mental, através da construção e } \\
\text { interpretação de quadros, modelos, mapas, } \\
\text { conceitos ou esquemas. }\end{array}$ & $\begin{array}{l}\text { Pessoas (e } \\
\text { suas mentes) }\end{array}$ & $\begin{array}{l}\text { Fonte de } \\
\text { cognição, } \\
\text { passiva ou ativa. }\end{array}$ \\
\hline $\begin{array}{l}\text { Aprendizado } \\
\text { (Descritiva) }\end{array}$ & $\begin{array}{l}\text { Processo emergente, os estrategistas podem ser } \\
\text { encontrados por toda a organização e as pretensas } \\
\text { formulação e implementação entrecruzam-se }\end{array}$ & $\begin{array}{l}\text { Aprendizes } \\
\text { (quem puder) }\end{array}$ & $\begin{array}{l}\text { Sensível ao } \\
\text { aprendizado de } \\
\text { todos }\end{array}$ \\
\hline Poder (Descritiva) & $\begin{array}{l}\text { Processo de negociação de micropoder dentro da } \\
\text { organização numa ação política ou de macropoder } \\
\text { usando o seu poder sobre o mundo externo. }\end{array}$ & $\begin{array}{l}\text { Qualquer um } \\
\text { com poder }\end{array}$ & $\begin{array}{l}\text { Fraca (micro), } \\
\text { não específica } \\
\text { (Macro) }\end{array}$ \\
\hline $\begin{array}{l}\text { Cultural } \\
\text { (Descritiva) }\end{array}$ & $\begin{array}{l}\text { Processo social concentrado no interesse comum e } \\
\text { na integração. }\end{array}$ & Coletividade & Simbólica \\
\hline $\begin{array}{l}\text { Ambiental } \\
\text { (Descritiva) }\end{array}$ & $\begin{array}{l}\text { Processo de reação, onde as organizações usam } \\
\text { diferentes graus de liberdade para manobrarem nos } \\
\text { seus ambientes. }\end{array}$ & Ambiente & Impotente \\
\hline $\begin{array}{l}\text { Configuração } \\
\text { (Integração) }\end{array}$ & $\begin{array}{l}\text { Processo de transformação, integradora em } \\
\text { literatura e prática, as organizações são vistas como } \\
\text { estados estruturais e a estratégia a forma de } \\
\text { mudanças destes. }\end{array}$ & $\begin{array}{l}\text { Especialmente } \\
\text { o principal } \\
\text { executivo }\end{array}$ & $\begin{array}{l}\text { Agente de } \\
\text { mudanças } \\
\text { periódica }\end{array}$ \\
\hline
\end{tabular}

Fonte: Mintzberg, Ahlstrand e Lampel (2000, p. 129). Transcrição integral.

Nas dez escolas de pensamento estratégico apresentado no Quadro 20, os agentes responsáveis pela formulação da estratégia vão desde executivos do nível institucionais (desenho) até os membros de toda a organização (cultural). A liderança pode ser autocrática (desenho) até de líderes informais e liderados (aprendizado).

Nesse sentido, a gestão estratégica de pessoas pode contribuir para o bem-estar e a qualidade de vida no trabalho de seus colaboradores.

\subsection{Bem-Estar e Qualidade de Vida no Trabalho (QVT)}

Nesta seção são demonstrados os fundamentos do bem-estar, a satisfação no trabalho, a qualidade de vida, a qualidade de vida no trabalho com sua evolução, características, modelos de análises e seus indicadores, e o bem-estar organizacional BEO e suas variáveis. 
Danna e Griffin (1999) afirmam que bem-estar tem grande repercussão nas organizações e cita três grandes áreas de pesquisa que relacionam o ambiente organizacional e a saúde dos trabalhadores: 1) refere-se ao relacionamento de locais de trabalhos perigosos com doenças do trabalho e determinadas enfermidades; 2) diz respeito ao relacionamento entre estresse e as condições de trabalho; 3) engloba o relacionamento de doenças específicas com características de personalidade ou tipos de ambientes de trabalho. O bem-estar é abordado, então, com distúrbios e patologias provocadas pelo ambiente de trabalho.

Desta forma, saúde e bem-estar estão relacionados, mas não são sinônimos, pois algumas pessoas doentes podem apresentar um nível de bem-estar maior do que indivíduos sadios. Bem-estar envolve a combinação de indicadores psicológicos como afeto, frustração e ansiedade e indicadores físicos como pressão sanguínea e saúde física no geral. A Organização Mundial da Saúde (O.M.S., 2007) define saúde como um estado de bem-estar físico, mental e social completo e não meramente a falta de doença ou enfermidade.

O bem-estar pode ser psicológico e subjetivo. Eles são fundamentais para a compreensão do bem-estar dos indivíduos. De acordo com Diener (2000), o bem-estar subjetivo são as avaliações cognitivas e afetivas que as pessoas fazem de suas próprias vidas, através de auto-relatos de suas vidas, descrevendo a experiência interna do indivíduo e são relacionadas às condições de saúde, conforto e riqueza. Portanto, o bem-estar subjetivo pode ser definido por três dimensões: satisfação com a vida, presença de afeto positivo e ausência de afeto negativo. A satisfação geral com a vida é formada pelas percepções dos indivíduos deles mesmos e a satisfação com determinados aspectos importantes como o trabalho, e o afeto positivo estaria ligado a um menor número de experiências de emoções negativas.

Meleiro (2005) relata que o bem-estar psicológico é distinto do bem-estar subjetivo, mas se complementam, pois são interdependentes permitindo combinações viáveis a ambos. $\mathrm{O}$ primeiro é baseado em concepções sobre o funcionamento psicológico da psicologia do desenvolvimento e da literatura de saúde mental. As dimensões de bem-estar psicológico fundamentam-se em desafios impostos pela vida do indivíduo ao longo de seu desenvolvimento.

De acordo com a mesma autora, o bem-estar no trabalho é um construto complexo e multidimensional que ganha destaque nos estudos organizacionais. Compreende as variáveis que fortalecem o vínculo dos funcionários com a empresa que trabalham, bem como contribui para a compreensão do comportamento humano nas empresas. 
O bem-estar no trabalho é baseado na satisfação, no seu envolvimento e comprometimento afetivo. A maioria das organizações não está no "ramo da satisfação no trabalho". Por isso, às vezes é difícil fazer com que os gerentes percebam a importância de compreender e melhorar as atitudes e os sentimentos dos seus funcionários para com o trabalho (WAGNER III; HOLLENBECK, 1999).

A satisfação no trabalho conforme Wagner III e Hollenbeck (1999, p.121), “é um sentimento que resulta da percepção de que nosso trabalho realiza ou permite a realização de valores importantes relativos ao próprio trabalho". Robins (2002, p. 21) entende a satisfação no trabalho como "a diferença entre as recompensas recebidas de fato pelo funcionário e aquilo que ele acredita merecer", ou seja, é mais uma atitude do que um comportamento em relação ao próprio trabalho.

As atitudes das pessoas em relação aos trabalhos executados determinam o grau de satisfação com o trabalho. Segundo Robbins (2002), os principais fatores relacionados com a satisfação no trabalho são: o trabalho mentalmente desafiador, as recompensas justas, as condições adequadas ao trabalho, o apoio dos colegas, o ajuste da personalidade com o cargo e a disposição genética do indivíduo.

Com o aumento da produtividade o funcionário muitas vezes, recebe elogios, promoções e/ou aumentos salariais, tornando-se mais satisfeito com o trabalho. Portanto, não é a satisfação que aumenta a produtividade e sim a produtividade que aumenta a satisfação (ROBBINS, 2002).

O mesmo autor defende a idéia de que as pessoas buscam posições que sejam compatíveis com seus interesses, valores e habilidades. Independentemente do nível de satisfação, os funcionários que apresentam melhor desempenho tendem a permanecer na organização, pois são reconhecidos, elogiados e recompensados. Portanto, percebe-se que o desempenho e a satisfação com o trabalho tendem a ser maiores quando seus próprios valores coincidem com os da organização.

Os funcionários podem expressar sua insatisfação de diversas formas, tais como: com reclamações, insubordinação, fuga de suas responsabilidades e até furto. Como cita Robbins (2002), os colaboradores insatisfeitos podem optar por sair da empresa e buscar um novo emprego que lhes proporcione satisfação, assim como podem tentar melhorar as condições de trabalho através da comunicação, podem ficar esperando passivamente as condições melhorarem, mantendo-se fiel à organização ou ainda, reduzir seu empenho na realização das tarefas, aumentando os erros e o absenteísmo, ou seja, fazendo com que a situação piore. 
Percebe-se então, que a satisfação com o trabalho engloba os conceitos de resultados, tratamento e procedimentos justos. Todos devem procurar descobrir quais são as atividades que lhe dão maior grau de satisfação e alegria e, conseqüentemente, praticá-las mais. Assim como se deve descobrir também, quais são os poucos problemas que causam a maioria das preocupações e assim eliminá-los, tornando-se, seres humanos mais felizes e satisfeitos.

Nesse contexto, há mais de duas décadas autores renomados no campo dos estudos sobre o trabalho, como Dejours e outros franceses contemporâneos, chamam a atenção para as condições ergonômicas e participativas do homem no ambiente de trabalho (LIMONGIFRANÇA, 1996).

Goulart e Sampaio (2004) relatam que o tema Qualidade de Vida no Trabalho (QVT) é representado, no passado, pela busca de satisfação do trabalhador e pela tentativa de redução do mal-estar e excessivo esforço físico no trabalho.

Vários pesquisadores entre eles: Elton Mayo, Maslow e Herzberg fundamentaram a importância da motivação humana e suas necessidades. Os estudos de dinâmica de grupo iniciados por Kurt Lewin, mostram que a convivência e a participação tendem a aumentar a rentabilidade no trabalho.

A expressão QVT só apareceu na literatura especializada no final da década de 1950, na Inglaterra. De acordo com Huse e Cummings e com Nadler citados por Goulart e Sampaio (2004), foi na década de 1970 que realmente emergiu o grande desenvolvimento da QVT, principalmente a criação de estudos a seu respeito nos EUA.

Neste contexto surgiram trabalhos relevantes como por exemplo, os de Werther e Davis na Suécia, Nadler e Lawler nos Estados Unidos, entre outros. Todos estes apresentam seu conceito para a questão da Qualidade de Vida no Trabalho - QVT com diversos enfoques baseados nos fatores físicos, psicológicos e sociais presentes no espectro da vida organizacional do ser humano.

Apesar de QVT ser um tema atual, pode-se perceber através do estudo de Nadler e Lawler citados por Fernandes (1996, p.42) e demonstrado no quadro 21, as diferentes concepções a seu respeito desde 1959, o que demonstra que esta não é apenas uma preocupação recente. 
Quadro 21 - Evolução do conceito de QVT

\begin{tabular}{|l|l|}
\hline Concepções Evolutivas de QVT & Características ou Visão \\
\hline $\begin{array}{l}\text { 1. QVT como uma variável (1959 } \\
\text { a 1972) }\end{array}$ & $\begin{array}{l}\text { Reação do indivíduo ao trabalho. Investigava-se como melhorar a } \\
\text { qualidade de vida no trabalho para o indivíduo. }\end{array}$ \\
\hline $\begin{array}{l}\text { 2. QVT como uma abordagem } \\
\text { (1969 a 1974) }\end{array}$ & $\begin{array}{l}\text { O foco era o indivíduo antes do resultado organizacional; mas, ao mesmo } \\
\text { tempo, buscava-se trazer melhorias tanto ao empregado como à direção. }\end{array}$ \\
\hline $\begin{array}{l}\text { 3. QVT como um método (1972 a a } \\
\text { 1975) }\end{array}$ & $\begin{array}{l}\text { Um conjunto de abordagens, métodos ou técnicas para melhorar o ambiente } \\
\text { de trabalho e tornar o trabalho mais produtivo e mais satisfatório. QVT era } \\
\text { vista como sinônimo de grupos autônomos de trabalho, enriquecimento de } \\
\text { cargo ou desenho de novas plantas com integração social e técnica. }\end{array}$ \\
\hline $\begin{array}{l}\text { 4. QVT como um movimento } \\
\text { (1975 a 1980) }\end{array}$ & $\begin{array}{l}\text { Declaração ideológica sobre a natureza e as relações dos trabalhadores com } \\
\text { a organização. Os termos "administração participativa" e "democracia } \\
\text { industrial" eram freqüentemente ditos como ideais do movimento de QVT. }\end{array}$ \\
\hline 5. QVT como tudo (1979 a 1982) & $\begin{array}{l}\text { Como panacéia contra a competição estrangeira, problemas de qualidade, } \\
\text { baixas taxas de produtividade, problemas de queixas e outros problemas } \\
\text { organizacionais. }\end{array}$ \\
\hline 6. QVT como nada (futuro) & $\begin{array}{l}\text { No caso de alguns projetos de QVT fracassarem no futuro, não passará de } \\
\text { um "modismo" passageiro. }\end{array}$ \\
\hline
\end{tabular}

Fonte: Nadler e Lawler citado por Fernandes (1996, p.42). Transcrição integral.

Fernandes (1996) conceitua QVT como uma gestão dinâmica e contingencial de fatores físicos, tecnológicos e sociopsicológicos que afetam a cultura e renovam o clima organizacional, refletindo-se no bem-estar do trabalhador e na produtividade das empresas.

Nesse estudo foi adotado como parâmetro a visão de Limongi-França (2007, p. 167), onde a gestão da QVT é "a capacidade de administrar o conjunto das ações, incluindo diagnóstico, implantação de melhorias e inovações gerenciais, tecnológicas e estruturais no ambiente de trabalho alinhada e construída na cultura organizacional, com prioridade absoluta para o bem-estar das pessoas da organização”. Dessa forma, essas ações devem ser planejadas, organizadas, dirigidas e controladas.

Sabe-se que as necessidades humanas variam conforme a cultura individual e organizacional. Assim sendo, existem vários modelos de QVT, dos quais são destacados os seguintes:

1) Modelo de QVT de Walton (1973), citado por Fernandes (1996), o qual se preocupa com todas as necessidades do ser humano, desde as básicas até a sua auto-realização, importando-se também com as condições da organização. Destaca a existência de oito fatores que afetam a QVT, conforme demonstrado no quadro 22. 
Quadro 22 - Critérios e Indicadores de QVT do Modelo de Walton

\begin{tabular}{|c|c|}
\hline Critérios & Indicadores de QVT \\
\hline $\begin{array}{l}1 \text { - Compensação justa e } \\
\text { adequada }\end{array}$ & $\begin{array}{l}\text { Eqüidade interna e externa } \\
\text { Justiça na compensação } \\
\text { Partilha dos ganhos de produtividade } \\
\text { Proporcionalidade entre salários }\end{array}$ \\
\hline 2 - Condições de trabalho & $\begin{array}{l}\text { Jornada de trabalho razoável } \\
\text { Ambiente físico seguro e saudável } \\
\text { Ausência de insalubridade }\end{array}$ \\
\hline $\begin{array}{l}3 \text { - Uso e desenvolvimento de } \\
\text { capacidades }\end{array}$ & $\begin{array}{l}\text { Autonomia / Qualidades múltiplas } \\
\text { Autocontrole relativo } \\
\text { Informações sobre o processo total do trabalho }\end{array}$ \\
\hline $\begin{array}{l}4 \text { - Oportunidade de crescimento } \\
\text { e segurança }\end{array}$ & $\begin{array}{l}\text { Possibilidade de carreira / Crescimento pessoal } \\
\text { Perspectiva de avanço salarial } \\
\text { Segurança de emprego }\end{array}$ \\
\hline $\begin{array}{l}5 \text { - Integração social na } \\
\text { organização }\end{array}$ & $\begin{array}{l}\text { Ausência de preconceitos / Senso comunitário } \\
\text { Igualdade/Mobilidade/Relacionamento }\end{array}$ \\
\hline 6 - Constitucionalismo & $\begin{array}{l}\text { Direitos de proteção do trabalhador } \\
\text { Privacidade pessoal / Tratamento imparcial } \\
\text { Liberdade de expressão } \\
\text { Direitos trabalhistas }\end{array}$ \\
\hline $\begin{array}{l}7 \text { - O trabalho e o espaço total de } \\
\text { vida }\end{array}$ & $\begin{array}{l}\text { Papel balanceado no trabalho } \\
\text { Estabilidade de horários } \\
\text { Poucas mudanças geográficas } \\
\text { Tempo para lazer da família }\end{array}$ \\
\hline $\begin{array}{l}8 \text { - Relevância social do trabalho } \\
\text { na vida }\end{array}$ & $\begin{array}{l}\text { Imagem da empresa/Práticas de emprego } \\
\text { Responsabilidade social da empresa } \\
\text { Responsabilidade pelos produtos }\end{array}$ \\
\hline
\end{tabular}

Fonte: Fernandes (1996, p. 48). Transcrição integral.

2) Modelo de Westley (1979) - De acordo com Westley (1979), citado por Fernandes (1996), esse modelo classifica e analisa quatro problemas que afetam diretamente e tornam-se obstáculos a QVT: o político, o econômico, o psicológico e o sociológico.

Econômico: eqüidade salarial, remuneração adequada, benefícios, carga horária, local de trabalho e ambiente externo.

Político: segurança no emprego, atuação sindical, retroinformação, liberdade de expressão, valorização do cargo e relacionamento com a chefia.

Psicológico: realização potencial, nível de desafio, desenvolvimento pessoal e profissional, criatividade, auto-avaliação, variedade de tarefa e identificação com a tarefa.

Sociológico: participação nas decisões, autonomia, relacionamento interpessoal, grau de responsabilidade e valor pessoal.

Para Westley (1979), citado por Rodrigues (2002, p. 86), “a insatisfação reflete a remuneração inadequada; a alienação, um sentimento de que o trabalho é pessoalmente prejudicial; e a autonomia, uma falta de envolvimento moral". 
Percebe-se então, que essa teoria é uma das mais abrangentes, pois leva em consideração os aspectos internos e externos à organização onde o trabalhador está inserido.

Através do quadro 23, pode-se identificar os problemas, seus sintomas e as ações e propostas para solucioná-los, de acordo com Westley (1979), citado por Rodrigues (2002).

\begin{tabular}{|l|l|l|l|l|}
\hline $\begin{array}{l}\text { Natureza do Quadro 23 - Origens de QVT do Modelo de Westley } \\
\text { problema }\end{array}$ & $\begin{array}{l}\text { Sintoma do } \\
\text { problema }\end{array}$ & $\begin{array}{l}\text { Ação para solucionar o } \\
\text { problema }\end{array}$ & Indicadores & Propostas \\
$\begin{array}{l}\text { Econômico } \\
(1850)\end{array}$ & Injustiça & União dos trabalhadores & $\begin{array}{l}\text { Insatisfação } \\
\text { Greves }\end{array}$ & $\begin{array}{l}\text { Cooperação } \\
\text { Divisão dos lucros } \\
\text { Participação nas } \\
\text { decisões }\end{array}$ \\
\hline $\begin{array}{l}\text { Político (1850- } \\
1950)\end{array}$ & Insegurança & Posições políticas & $\begin{array}{l}\text { Insatisfação } \\
\text { Greves } \\
\text { supervisionado } \\
\text { Conselho de } \\
\text { trabalhadores } \\
\text { Participação nas } \\
\text { decisões }\end{array}$ \\
\hline $\begin{array}{l}\text { Psicológico } \\
(1950)\end{array}$ & Alienação & Agentes de mudança & $\begin{array}{l}\text { Absenteísmo e } \\
\text { "Turnover" }\end{array}$ & $\begin{array}{l}\text { Enriquecimento das } \\
\text { tarefas }\end{array}$ \\
\hline Sociológico & Anomia & Autodesenvolvimento & $\begin{array}{l}\text { Ausência de } \\
\text { significado do } \\
\text { trabalho } \\
\text { Absenteísmo e } \\
\text { "Turnover" }\end{array}$ & $\begin{array}{l}\text { Métodos sócio-técnicos } \\
\text { aplicados aos grupos }\end{array}$ \\
\hline
\end{tabular}

Fonte: Westley (1979) citado por Rodrigues (2002, p. 88). Transcrição integral.

3) Modelo de Werther e Davis (1983), conforme Fernandes (1996) e Rodrigues (2002): este modelo leva em consideração o ambiente de trabalho, seu fluxo de produção e suas práticas. Afinal, quando se evita trabalhos mecanicistas, se valoriza a autonomia e as habilidades dos indivíduos, podendo-se dizer que os mesmos têm melhores condições de trabalho.

De acordo com Fernandes (1996) e Rodrigues (2002), esse modelo vê o projeto de cargos em três níveis: Organizacional: propósitos, objetivos, organização, departamentos e cargos; Ambiental: sociais, tecnológicos, culturais, econômicos e governamentais; e Comportamental: motivação, satisfação e necessidades de recursos humanos.

4) Modelo de Lippit (1978) citado por Fernandes (1996), representa um modelo de melhoria de QVT; deve satisfazer tanto as necessidades dos colaboradores quanto às da organização. O funcionário deve sentir-se valorizado, reconhecido e incentivado a desenvolver-se individual e profissionalmente, pois só assim conseguirá realizar-se. 
5) Modelo de Belanger (1973), defende que, para analisar a QVT é preciso considerar o trabalho em si, ou seja, a criatividade, a autonomia, o envolvimento e o feedback que o mesmo proporciona; assim como os crescimentos pessoais e profissionais, que acontecem através de treinamentos e relacionamentos na organização. As pessoas valorizam e assumem responsabilidade sobre as tarefas que possuem significado, e por isso recebem recompensas de ordem financeira ou não. Outros fatores importantes são o clima de criatividade e o conhecimento dos objetivos dentro da organização (FERNANDES, 1996).

No quadro 24 apresenta-se o Modelo de Belanger, com relação à QVT.

Quadro 24 - Modelo de QVT de Belanger e suas variáveis

\begin{tabular}{|l|l|l|l|}
\hline O trabalho em si & $\begin{array}{l}\text { Crescimento Pessoal e } \\
\text { Profissional }\end{array}$ & Tarefas com Significado & $\begin{array}{l}\text { Funções e Estruturas } \\
\text { Abertas }\end{array}$ \\
\hline Criatividade & Treinamento & Tarefas completas & Clima de criatividade \\
\hline Variabilidade & $\begin{array}{l}\text { Oportunidades de } \\
\text { crescimento }\end{array}$ & $\begin{array}{l}\text { Responsabilidade } \\
\text { aumentada }\end{array}$ & Transferência de objetivos \\
\hline Autonomia & $\begin{array}{l}\text { Relacionamento no } \\
\text { trabalho }\end{array}$ & $\begin{array}{l}\text { Recompensas financeiras / } \\
\text { não-financeiras }\end{array}$ & \\
\hline Envolvimento & Papéis organizacionais & Enriquecimento & \\
\hline Feedback & & & \\
\hline
\end{tabular}

Fonte: Fernandes (1996, p. 55). Transcrição integral.

6) Modelo de Huse e Cummings, citado por Rodrigues (2002, p. 90): afirma que a "QVT envolve as pessoas, o trabalho e a empresa". Existe também "a preocupação com o bem-estar do trabalhador e com a eficácia organizacional, assim como com a participação dos trabalhadores nas decisões e problemas do trabalho".

Este modelo é operacionalizado através de quatro programas: "a participação do trabalhador nos problemas e soluções organizacionais; o projeto do cargo; inovação no sistema de recompensa e a melhoria no ambiente de trabalho" (RODRIGUES, 2002, p. 90).

Os trabalhadores participam dos problemas e apresentam sugestões para solucioná-los através dos Ciclos de Controle de Qualidade (CCQ) e da participação em grupos de trabalho cooperativos. De acordo com os autores do modelo, os cargos são enriquecidos através da multiplicidade das tarefas, de grupos de trabalhos auto-regulados e da utilização do feedback.

A empresa torna-se responsável e comprometida com os colaboradores, no sentido de projetar, implantar e revisar o plano de cargos e salários, visando a diminuição das diferenças salariais. 
Segundo Rodrigues (2002), para melhorar o ambiente, é preciso fazer algumas mudanças físicas ou tangíveis nas condições de trabalho, tais como: mudança de móveis e equipamentos, além de flexibilidade de horário.

Huse e Cummings (1985) apud Rodrigues (2002, p. 91), afirmam que "a QVT afeta positivamente a produtividade de forma indireta", como mostra a ilustração 5.

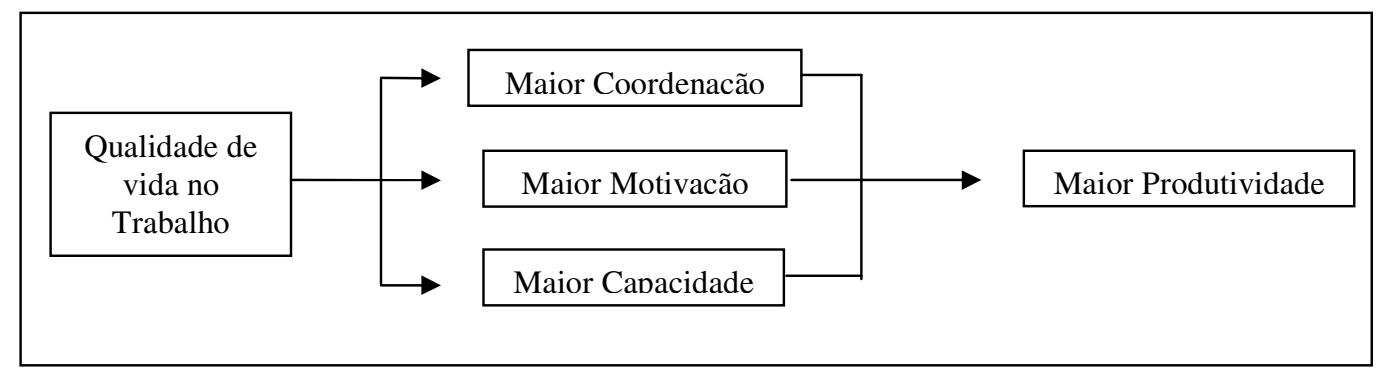

Ilustração 5 - Qualidade de Vida no Trabalho X Produtividade

Fonte: Huse e Cummings (1985) citado por Rodrigues (2002, p. 91). Transcrição integral.

7) Modelo de QVT de Nadler e Lawler, citado Rodrigues (2002): afirma que a QVT só melhora quando há incrementação de quatro aspectos: participação dos funcionários nas decisões; reestruturação do trabalho através do enriquecimento de tarefas e de grupos autônomos de trabalho; inovação no sistema de recompensas para influenciar o clima organizacional e melhoria no ambiente de trabalho quanto às condições físicas e psicológicas, incluindo também o horário de trabalho.

Segundo Rodrigues (2002), um programa de QVT só terá sucesso se for desenvolvido em níveis diferentes; se ocorrerem mudanças nos sistemas de gerenciamento, no comportamento gerencial e nas disposições organizacionais.

De acordo com Nadler e Lawler (1983) apud Rodrigues (2002, p. 92), “provavelmente o fator determinante mais crítico de sucesso, de viabilidade e de impacto em longo prazo dos esforços de QVT é a estrutura dos processos participantes que são criados”.

8) Modelo de Hackman e Oldham (1975). De acordo com os autores, a QVT pode ser avaliada quanto às dimensões da tarefa, estados psicológicos críticos e pelos resultados pessoais e de trabalho. As dimensões do cargo são determinantes da QVT, pois produzem satisfação e automotivam as pessoas para o trabalho.

As dimensões de cargo destacadas por Fernandes (1996) são:

a) Variedade de habilidades - o cargo deve exigir diversas habilidades das pessoas.

b) Identidade da tarefa - a pessoa deve realizar uma tarefa do início ao fim para entender e apropriar-se dos resultados. 
c) Significado da tarefa - todo trabalhador deve saber qual o impacto do seu trabalho sobre o trabalho dos outros.

d) Autonomia - a pessoa deve ter responsabilidade para planejar e executar suas tarefas além de ter autonomia e independência para desempenhá-las.

e) Retroação do próprio trabalho - a tarefa deve proporcionar informação de retorno para que a pessoa possa auto-avaliar seu desempenho.

f) Retroação extrínseca, ou seja, deve haver retorno dos superiores ou clientes a respeito do desempenho de determinada tarefa, de cada pessoa.

g) Inter-relacionamento - a tarefa deve possibilitar contato interpessoal com outras pessoas, sejam clientes e/ ou fornecedores internos ou externos.

No quadro 25 está esquematizado o modelo das dimensões básicas da tarefa, de acordo com Hackman e Oldham (1975).

Quadro 25 - Modelo das Dimensões Básicas da Tarefa

\begin{tabular}{|l|l|l|}
\hline Dimensões da Tarefa & Estados Psicológicos Críticos & $\begin{array}{l}\text { Resultados Pessoais e de } \\
\text { Trabalho }\end{array}$ \\
\hline Variedade de habilidades (VH) & \multirow{2}{*}{$\begin{array}{l}\text { Percepção da significância do } \\
\text { trabalho (PST) }\end{array}$} & $\begin{array}{l}\text { Satisfação geral com o trabalho } \\
\text { (SG) }\end{array}$ \\
\cline { 3 - 4 } Identidade de tarefa (IT) & $\begin{array}{l}\text { Motivação interna para o trabalho } \\
\text { (MIT) }\end{array}$ \\
\hline Inter-relacionamento (IR) & $\begin{array}{l}\text { Percepção da responsabilidade } \\
\text { pelos resultados (PRT) }\end{array}$ & $\begin{array}{l}\text { Produção de trabalho de alta } \\
\text { qualidade (PTQ) }\end{array}$ \\
\hline Autonomia (AU) & $\begin{array}{l}\text { Conhecimento dos reais resultados } \\
\text { Feedback do próprio trabalho } \\
\text { (FT) }\end{array}$ & Absenteísmo e rotatividade baixos \\
\hline Feedback extrínseco (FE) & chalho (CRT) & \\
\hline
\end{tabular}

Fonte: Walton (1975) citado por Fernandes (1996, p. 56). Transcrição integral.

9) Modelo de Gonçalves (1998): defende a utilização de uma metodologia apropriada para a avaliação da QVT, levando em consideração a percepção de todos os envolvidos no processo.

De acordo com esse modelo, os funcionários são os responsáveis pelos apontamentos dos fatores determinantes da qualidade de vida no trabalho, pois conhecem melhor do que ninguém a empresa em que trabalham, suas características e deficiências, além de seus serviços, produtos e sua cultura organizacional (GONÇALVES,1998).

Esse modelo caracteriza a QVT em dois grandes grupos: condições ambientais e organizacionais de trabalho, conforme demonstrado através do quadro 26. 
Quadro 26 - Modelo das Variáveis de Gonçalves

\begin{tabular}{|c|c|c|}
\hline \multirow{5}{*}{$\begin{array}{l}\text { Condições } \\
\text { Ambientais }\end{array}$} & \multirow{3}{*}{ Condições Físicas } & Ambiente arquitetônico / ergonômico \\
\hline & & Ambiente térmico \\
\hline & & Ambiente sonoro / Ambiente luminoso \\
\hline & Condições Químicas & Insalubridade / Periculosidade \\
\hline & Condições Biológicas & Ambiente bacteriológico \\
\hline \multirow{13}{*}{$\begin{array}{l}\text { Condições } \\
\text { Organizacionais }\end{array}$} & \multirow{8}{*}{ Métodos de Trabalho } & Integração / Burocracia \\
\hline & & Jornada de trabalho \\
\hline & & Acúmulo de tarefas \\
\hline & & Rodízio de profissionais \\
\hline & & Material de apoio / Pessoas / Sala \\
\hline & & Eficiência das reuniões \\
\hline & & Organização da empresa \\
\hline & & Valorização do profissional \\
\hline & \multirow[b]{2}{*}{ Comunicação } & Informações Gerenciais \\
\hline & & $\begin{array}{l}\text { Informações s/ modelos e resultados de outras } \\
\text { empresas. }\end{array}$ \\
\hline & \multirow{2}{*}{ Tecnologia } & Qualidade e Quantidade de equipamentos \\
\hline & & Facilidade de manuseio \\
\hline & \multicolumn{2}{|c|}{ Horários e turnos. Formação. Política Salarial. } \\
\hline
\end{tabular}

Dias (2004) afirma que os modelos dos diversos autores de QVT são ferramentas que tratam dos aspectos relacionados à satisfação dos empregados no local de trabalho. Esses modelos podem ser utilizados em vários segmentos sócio-técnicos, que visam melhorar o sistema homem-máquina e prevêem a participação dos trabalhadores ao longo de todo o estudo.

Goulart e Sampaio (2004) relatam a chamada Terceira Revolução Industrial a partir de 1990, com a inserção de vários países em desenvolvimento entre eles o Brasil. Em razão disso foram adotadas novas tecnologias administrativas e de produção, causando como conseqüência uma maior desumanização do trabalho.

Nesse sentido, ganha relevância o tema QVT nos dias atuais, pois se refere a escolhas de bem-estar e percepção do que pode ser feito para atender a expectativas criadas tanto por gestores como pelos usuários - funcionários das organizações - das ações de QVT no ambiente organizacional.

Limongi-França (2004) afirma que o tema QVT é abordado em três escolas de pensamento, de acordo com a natureza das indagações, dos conceitos e abordagens. Destacam-se as escolas: Socioeconômica, escola organizacional e escola da Condição Humana no Trabalho, as quais são relatadas a seguir:

a) Escola Socioeconômica, que tem como principal idealizador Giddens, o qual defendeu a ajuda aos cidadãos a conseguir seu espaço por meio da globalização, transformação na vida pessoal e relacionamento com a natureza. Os valores difundidos estão 
assentados principalmente no princípio da igualdade social, na proteção aos vulneráveis, na liberdade com autonomia, nos direitos com responsabilidade, na autoridade com democracia e no pluralismo cosmopolita, entre outros, que afrontam o conservadorismo neoliberal, principal fonte ideológica da globalização.

Giddens (2000) afirma que a globalização trouxe impactos profundos em diversos aspectos (econômicos, culturais, políticos, sociais, religiosos) para a sociedade, e está reestruturando o modo de vida das pessoas, causando conseqüências desiguais e extremas de grupos fundamentalistas, nacionalistas, entre outros.

Relata que o homem está afetando o clima do planeta com a poluição ambiental, causando um desequilíbrio no ecossistema. Porém o risco sempre existiu na atividade humana, mas os impactos atuais podem levar a conseqüências inimagináveis. Por outro lado, o risco tem seu lado positivo, pois é a dinâmica mobilizadora de uma sociedade propensa a mudança.

A tradição é representada por símbolos de identidade nacional, que traduzem determinados costumes de um determinado povo. As tradições e os costumes foram a essência da vida das pessoas durante a maior parte da história do homem. Ela define um tipo de verdade, em um determinado momento, e define uma estrutura para a ação. Em um mundo globalizado as instituições e as pessoas estão se libertando do domínio da tradição, dando vez à objetividade e a racionalidade.

Outro aspecto é a família tradicional que está sofrendo modificações nesse cenário atual, pois em países ocidentais leis facilitam a dissolução dos casamentos, a mulher ganha espaço no mercado de trabalho, assumindo novos papéis, a homossexualidade ganha amparo na legislação em vários países europeus, e a união informal ganha cada vez mais força.

Giddens (2000) aborda a questão da democracia, relatando a queda do muro de Berlin na Alemanha e sua definição do sistema: envolve competição efetiva entre partidos políticos por cargos de poder, acompanhado por liberdades civis de expressão, discussão, juntamente com a liberdade de formar grupos ou associações políticas e de neles ingressar.

Nesse mesmo sentido, Giannetti (2002) destaca os indicadores objetivos e subjetivos de bem-estar e afirma que os homens visam o alcance da felicidade e o prazer na vida desde o início da sua existência. Quais seriam os determinantes da felicidade? De acordo com o autor, são os estados de consciência aprazíveis; fatores pessoais, socioeconômicos e culturais; fatores biopsicosociais com a sua vida. 
Os componentes do bem-estar humano são relacionados com a dimensão objetiva que é visível e pode ser medida, como condições de vida, nutrição, moradia, renda, poluição etc. A dimensão subjetiva é a experiência interna do sujeito, suas percepções do ambiente e de si mesmo.

b) Escola Organizacional: o foco está no local das relações de trabalho. As principais contribuições foram dos pensadores de modelos de administração, como Taylor, Elton Mayo, McGregor, Argyris, Maslow, Herzberg, Juran, Deming (qualidade pessoal como parte do processo de qualidade total) e atualmente os trabalhos de Schein, Handy, Mintzberg e Ulrich.

De acordo com Limongi-França (2004), essa escola contribui nas organizações com os seguintes aspectos:

- expansão dos processos de qualidade e produtividade para o de qualidade pessoal;

- política de gestão de pessoas - valorização e capacitação;

- marketing - imagem corporativa e comunicação interna;

- tempo livre - desenvolvimento cultural, hábitos de lazer e esporte;

- risco e desafio como fatores de motivação e comprometimento.

c) A Escola Condição Humana no Trabalho considera que toda pessoa é um complexo biopsicossocial, ou seja, tem potencialidades biológicas, psicológicas e sociais que respondem com variadas combinações e intensidades nesses três níveis interdependentes, de forma simultânea, às condições de vida. Os fatores psicossociais são fundamentais para explicar a saúde e a doença das pessoas nos dias atuais.

A dimensão organizacional foi criada a fim de atender às especificidades da cultura e do ambiente organizacional, para fazer alusão às questões de imagem corporativa, inovação e tecnologia, sistemas de controle, movimentações e registros, programas de treinamento e desenvolvimento, dentre outras atividades.

Dessa forma, a perspectiva da condição humana no trabalho, voltou-se para a questão do moral no grupo com base na demonstração de que uma fábrica é uma instituição social, para necessidades de suas diversas hierarquias e classes, tais como as básicas e secundárias, que geram estabilidade de interesse e comportamento de continuidade, estilos de liderança e resultados entre funcionários e empresa (LIMONGI-FRANÇA, 2007).

As diferentes Escolas de QVT fornecem importantes subsídios para consolidar uma nova perspectiva na administração, criando novas atitudes nas organizações e mudanças de estilos de vida das pessoas, em busca de qualidade de vida dentro e fora do trabalho. 
Os países desenvolvidos têm experimentado inovações em QVT, por meio de novas formas de organização do trabalho. No Brasil, o assunto tem despertado interesse no meio empresarial pela contribuição que pode oferecer para a satisfação do empregado e para o aumento de produtividade.

Limongi-França (2007) afirma que diversas ciências têm contribuído e influenciado a construção de novas abordagens em gestão de pessoas e QVT como: a saúde (expectativas de vida); ecologia (ecossistema/desenvolvimento sustentado); ergonomia (conforto e desempenho); psicologia (afetos e valores pessoais); economia (bens finitos); sociologia (influências simbólicas); administração (velocidade e mudanças); e engenharia (tecnologia e produção enxuta).

Destaca-se na mesma obra, os níveis de atuação considerando múltiplas possibilidades de enfoque na gestão da QVT. Podem-se definir os seguintes níveis e implicações na estruturas das organizações: a) gestão estratégica de QVT (é declarada na missão e política da empresa); b) gestão gerencial de QVT (atribuições das áreas funcionais - ênfase em objetivos, metas e produtividade organizacional); c) gestão operacional de QVT (há ações específicas aleatórias, reativas ou planejadas - que visam o bem-estar e à conscientização de novas práticas de estilo de vida para as pessoas da empresa).

Como seqüência natural para esta abordagem, Limongi-França (1996, 2004, 2005) define o fator "biopsicossocial" que encerra em uma palavra os aspectos relevantes responsáveis pela maior abrangência nos estudos de QVT. A palavra biopsicossocial tem sua origem na Medicina Psicossomática, que propõe uma visão integral e holística do ser humano, em contraposição à visão cartesiana que o divide em partes. Neste conceito, toda pessoa possui potencialidades biológicas, psicológicas e sociais que respondem simultaneamente às condições de vida, sendo assim um ser complexo.

As variáveis são selecionadas a partir do conceito de Qualidade de Vida no Trabalho em relação às ações da empresas: programas, campanhas, gestão, levantamentos e controle de resultados.

Essas variáveis referem-se ao grau de satisfação dos "clientes internos" quanto à capacidade de uma gestão compatível com as necessidades organizacionais voltadas para a performance de bem-estar dos colaboradores. O quadro 27 retrata os fatores Biopsicossocial e Organizacional, o significado de BEO, as ações de melhorias e as dificuldades existentes. 
Quadro 27 - Variáveis qualitativas sobre o conceito de Bem-estar organizacional

\begin{tabular}{|c|c|c|c|}
\hline Área de investigação & Significado de BEO & Melhorias & Dificuldades \\
\hline Biológica & $\begin{array}{l}\text { - Saúde } \\
\text { - Segurança } \\
\text { - Ausência de acidentes }\end{array}$ & $\begin{array}{l}\text { - Sistema de alimentação } \\
\text { - Ginástica laboral } \\
\text { - Controle de doenças }\end{array}$ & $\begin{array}{l}\text { - Existência de tarefas } \\
\text { perigosas } \\
\text { - Ausência por licenças } \\
\text { médicas } \\
\text { - Necessidade de } \\
\text { alimentação e repouso }\end{array}$ \\
\hline Psicológica & $\begin{array}{l}\text { - Amor } \\
\text { - Paz } \\
\text { - Realização pessoal }\end{array}$ & $\begin{array}{l}\text { - Valorização do } \\
\text { funcionário } \\
\text { - Desafios } \\
\text { - Sistemas de participação }\end{array}$ & $\begin{array}{l}\text { - Cobrança excessiva de } \\
\text { resultados } \\
\text { - Relacionamento entre os } \\
\text { empregados } \\
\text { - Falta de motivação e } \\
\text { interesse } \\
\end{array}$ \\
\hline Social & $\begin{array}{l}\text { - Confiança } \\
\text { - Amizade } \\
\text { - Responsabilidade }\end{array}$ & $\begin{array}{l}\text { - Educação para o } \\
\text { trabalho } \\
\text { - Benefícios familiares } \\
\text { - Atividades culturais e } \\
\text { esportivas }\end{array}$ & $\begin{array}{l}\text { - Falta de qualificação de } \\
\text { profissionais } \\
\text { - Condições culturais e } \\
\text { econômicas dos } \\
\text { empregados } \\
\text { - Problemas familiares } \\
\text { dos empregados } \\
\end{array}$ \\
\hline Organizacional & $\begin{array}{l}\text { - Investimento } \\
\text { - Humanismo } \\
\text { - Competitividade }\end{array}$ & $\begin{array}{l}\text { - Clareza nos } \\
\text { procedimentos } \\
\text { - Organização geral } \\
\text { - Contato com o cliente }\end{array}$ & $\begin{array}{l}\text { - } \text { Processos de } \\
\text { produção/tecnologia } \\
\text { - Pressão dos clientes } \\
\text { - Preparo da } \\
\text { documentação }\end{array}$ \\
\hline
\end{tabular}

Fonte: Limongi-França (2004). Transcrição integral.

Limongi-França (2005, p.7) afirma que a variável biológica refere-se às características físicas herdadas ou adquiridas pelo ser humano, ao nascer e durante toda a vida. Essa variável considera o "metabolismo, resistências e vulnerabilidades dos órgãos ou sistemas". Os indicadores empresariais de G-QVT envolvem a semana interna de prevenção de acidentes, controle de riscos ergonômicos, ambulatório médico, ginástica laboral, refeitório, saúde e CIPA.

Já a variável psicológica considera os processos afetivos, emocionais e de raciocínio, conscientes ou inconscientes, que formam a personalidade da pessoa ou o seu modo de perceber e se posicionar diante das pessoas e das circunstâncias do dia-a-dia. Envolvem ações como recrutamento e seleção, avaliação de desempenho, camaradagem - clima organizacional, carreira, salário e vida pessoal.

A variável social compreende os valores, as crenças, o papel na família, no trabalho e em todos os grupos e comunidades a que cada pessoa pertence e de que participa. Os indicadores empresariais envolvem convênios comerciais, tempo livre - lazer, filhos, cesta básica, previdência privada e financiamento de cursos.

A variável organizacional considera a produtividade, o humanismo e o investimento no ser humano; os indicadores empresariais de gestão de QVT envolvem a imagem, 
treinamento \& desenvolvimento, processos e tecnologia, comitês de decisão, ausência de burocracia e rotinas de pessoal.

As variáveis são selecionadas a partir da visão biopsicossocial e organizacional em relação às ações da empresas: programas, campanhas, gestão, levantamentos e controle de resultados.

É normalmente analisado o grau de satisfação dos colaboradores quanto à capacidade de uma gestão compatível com as necessidades organizacionais voltadas para a performance do seu bem-estar em uma visão global e abrangente.

Segundo Limongi-França (2007), o cenário atual das empresas é dinâmico e marcado por diversas inquietudes causando novas atitudes das empresas e necessidades de mudança no modo de vida das pessoas. A base de análise do bem-estar nas organizações é constituída das ações e programas denominados QVT, especialmente nas questões gerenciais. Os fatores culturais da G-QVT no trabalho são: a visão de pessoa, produtividade, legitimidade, perfil do administrador e cultura organizacional.

A mesma autora afirma que a QVT é uma resposta às pressões da vida moderna diante da vida com a globalização. As competências para a G-QVT podem ser identificadas especialmente nas áreas da saúde, benefícios, gestão de pessoas, engenharia de produção, ergonomia, sistemas de gestão da qualidade, pesquisa, inovação tecnológica, balanço social, marketing e atividades de responsabilidade social.

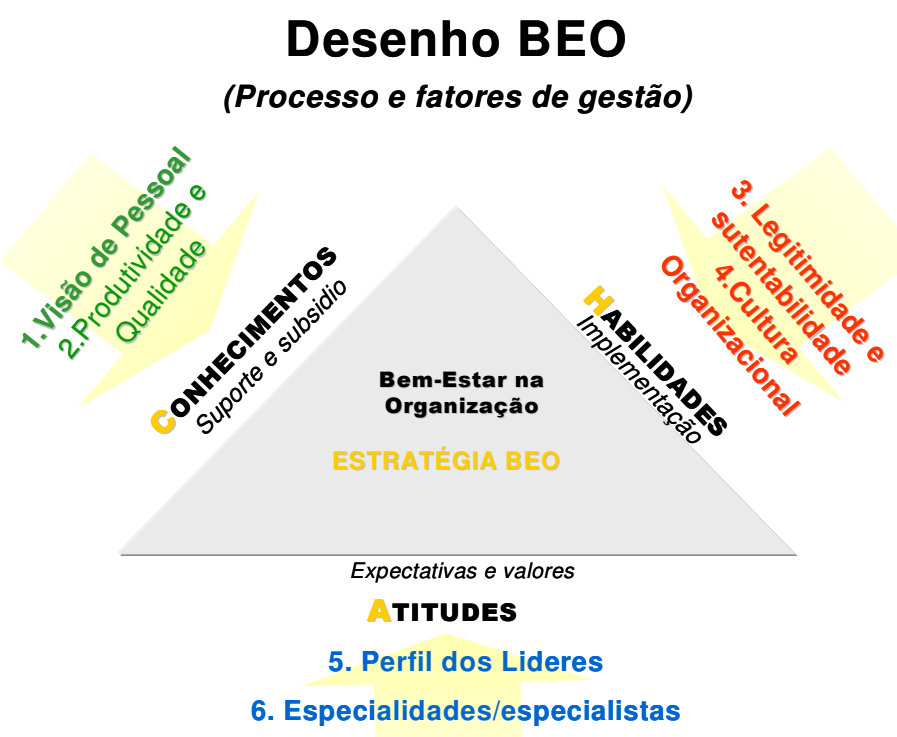

Ilustração 6 - Triângulo do Bem-Estar-Organizacional (BEO) e suas Variáveis Fonte: Limongi-França (2004). Transcrição integral. 
A ilustração 6 apresenta o triângulo do BEO sendo seus componentes: 1) Visão de pessoal (tradicional ou transformada), 2) Produtividade e Qualidade (metas, procedimentos, normas), 3) Legitimidade e Sustentabilidade (dos programas de BEO, políticas de RH), 4) Cultura organizacional (forte, com valores disseminados), 5) Perfil dos líderes (orientação para resultados, visionários, transformadores) e 6) Especialidades.

A autora relata que o tripé conceitual do modelo é formado pelo conhecimento do negócio, técnicas e estratégias. A nova competência tem focos: a) no ambiente organizacional; b) no âmbito do conhecimento; c) nos sistemas de informação e tecnologia; d) no âmbito das interfaces da administração.

O modelo conceitual da competência do bem-estar deve estar fundamentado na integração com a comunidade, as trocas justas entre organizações e pessoas no trabalho, ocasionando o bem-estar social. Deve-se incluir os conhecimentos como suporte com o conceito de QVT, suas práticas e valores, as habilidades envolvendo a implementação e as atitudes dos gestores e clientes internos e externos.

Para que esse modelo obtenha sucesso é necessário que os gestores das organizações aprendam a mudar - aprender a "desaprender", principal requisito para o administrador. Focos do perfil: educação formal, exercício da profissão e demandas das empresas. Sua atuação viabiliza a gestão de QVT mais efetiva e consistente com as necessidades das pessoas e das empresas" (LIMONGI-FRANÇA, 2004, p. 73).

Nesse sentido, a gestão da qualidade de vida no trabalho (GQVT) é entendida de acordo com Limongi-França (2007, p. 36) "como um conjunto de escolhas de bem-estar no trabalho - que garante proteção, preservação e desenvolvimento humano durante o exercício do trabalho, dentro e fora do espaço organizacional."

A qualidade de vida no trabalho tem ligação com as formas de relações de trabalho e suas variáveis, que são apresentadas a seguir.

\subsection{Relações de Trabalho}

Nesse item são abordados temas relevantes para o entendimento das relações de trabalho e suas variáveis como: o processo de reestruturação produtiva; a flexibilização nas relações de trabalho; o trabalho x emprego; os significados do trabalho ao longo da história e as mudanças no sistema brasileiro de relações de trabalho. 
O processo de reestruturação produtiva se caracteriza pela implementação de formas de organização e gestão do trabalho inspiradas no toyotismo que ultrapassou os muros da montadora japonesa e se universalizou através dos investimentos em novas tecnologias, um intenso processo de terceirização dos negócios e subcontratação de empresas e do trabalho. Isso é decorrente dos novos padrões de competitividade que implicam em mudanças culturais, de convicções políticas, exigências econômicas e novos estilos de vida e trabalho. Nesse contexto, há um agravamento das desigualdades sociais (STEFANO; NOGUEIRA, 2006).

O trabalho no atual sistema econômico e social é modificado com o objetivo de ampliar as formas de extração e exploração da força de trabalho, a qual amplia sobremaneira o trabalho excedente sobre o necessário na equação complexa da expansão do trabalho morto, incorporado nos meios de produção avançados, sobre o vivo e desse modo, procura diminuir a tendência da taxa decrescente dos lucros e garantir a dominação política e ideológica do sistema capitalista (ANTUNES, 1999).

A flexibilização das relações de trabalho em diversos formatos (jornada, contratos, horário, processos, remuneração etc...) implica na redefinição dos direitos sociais para os trabalhadores. Dependendo do país, as empresas têm plena liberdade para desempregar trabalhadores sem penalidades financeiras (VASAPOLLO, 2005).

Estes aspectos apontam perspectivas pessimistas para a sociedade, pois a mudança do mundo do trabalho, que transcende fronteiras nacionais e é resultado do complexo de transformações produtivas, promove o desemprego estrutural e a precariedade do trabalho assalariado com poucas perspectivas futuras.

A crescente concorrência internacional tem obrigado as empresas a cortar custos, com o objetivo de obter preços menores e qualidade elevada para os seus produtos. Nessa reestruturação, estão sendo eliminados postos de trabalho, tendência que é chamada de desemprego estrutural.

Morin (2001, p. 21) afirma que emprego trata-se da ocupação de um indivíduo, "correspondendo ao conjunto de atividades remuneradas em um sistema organizado economicamente.” Indica relações de remuneração e condições de trabalho entre empresa e funcionário.

O conceito de emprego está sendo substituído pelo conceito mais amplo de trabalho enquanto ocupação por meio de tarefas, projetos, missões a executar e atividades a desempenhar. O processo de competição não é apenas por salários, como mostra a teoria do 
capital humano, mas por empregos, onde pessoas com níveis mais elevados de escolarização ocupam cargos melhor remunerados (STEFANO; GOMES FILHO, 2004b).

Etimologicamente, trabalhar, travailler (francês) e trabajar (espanhol) têm a mesma origem do latim vulgar tripiliare - derivado de tripalium, instrumento de tortura e castigo para escravos, formado de três hastes ou paus. Laborare, (latim, significava balançar o corpo sob uma carga pesada e em geral era usado para designar o sofrimento e o mau trato do escravo. Respectivamente em inglês e em alemão, work $e$ werke estão ligados à atividade criativa, enquanto labour e arbeit têm conotação de esforço e cansaço) (ALBORNOZ, 2002).

Sennett (2000) explica que o sentido da palavra job (serviço ou emprego), que em inglês do século XIV significava bloco ou parte de alguma coisa que se podia transportar numa carroça de um lado para o outro, é trazido de volta pela flexibilidade do trabalho, na medida em que as pessoas "fazem blocos, partes de trabalho, no curso de uma vida". Assim, ao conteúdo semântico inicial de sofrer, agregou-se também o de esforçar-se, laborar, obrar.

A obra de Mills (1979) apresenta o trabalho como um instrumento de ganha-pão do homem. Pode-se dizer que nem o amor, nem o ódio ao trabalho são inerentes às pessoas, ou a qualquer tipo de ocupação, desse modo, não têm um significado intrínseco. O quadro 28 demonstra os significados do trabalho durante a história, em que se encontram diversos entendimentos.

Quadro 28 - Os significados do trabalho ao longo da história

\begin{tabular}{|l|l|}
\hline \multicolumn{1}{|c|}{ Povos/Autores } & \multicolumn{1}{c|}{ Significados do Trabalho } \\
\hline Gregos antigos & o trabalho manual e mecânico deveria ser realizado pelos escravos \\
\hline Hebreus & $\begin{array}{l}\text { o trabalho uma "labuta penosa", a que o homem estava condenado pelo } \\
\text { pecado }\end{array}$ \\
\hline Cristianismo & $\begin{array}{l}\text { o trabalho era uma punição para o pecado e servia para afastar os maus } \\
\text { pensamentos provocados pelo ódio }\end{array}$ \\
\hline Lutero & $\begin{array}{l}\text { o estabeleceu como "a base e a chave da vida", todo aquele capacitado } \\
\text { deveria fazê-lo, manter-se pelo trabalho era um modo de servir a Deus }\end{array}$ \\
\hline Calvinismo & $\begin{array}{l}\text { arrastou o homem ainda mais para o ritmo do trabalho moderno - agir de } \\
\text { maneira racional e metódica, contínua e árdua, para pertencer aos eleitos. }\end{array}$ \\
\hline Renascimento & $\begin{array}{l}\text { através do trabalho, o homem tornava-se um criador e podia realizar } \\
\text { qualquer coisa }\end{array}$ \\
\hline $\begin{array}{l}\text { Economia política } \\
\text { Adam Smith e D. Ricardo }\end{array}$ & $\begin{array}{l}\text { O trabalho como fonte de toda a riqueza. } \\
\text { A divisão do trabalho e eficiência econômica. } \\
\text { O trabalho como valor. }\end{array}$ \\
\hline $\begin{array}{l}\text { Materialismo Histórico } \\
\text { K. Marx }\end{array}$ & $\begin{array}{l}\text { Trabalho como processo de humanização } \\
\text { Exploração e alienação do trabalho; teoria do valor - valor de uso e valor } \\
\text { de troca; contradição entre as relações sociais de produção e o } \\
\text { desenvolvimento das forças produtivas. }\end{array}$ \\
\hline Taylor / Ford / Fayol & $\begin{array}{l}\text { Divisão do trabalho na organização empresarial. Racionalização e } \\
\text { padronização do trabalho. Fragmentação das tarefas. }\end{array}$ \\
\hline
\end{tabular}




\begin{tabular}{|c|c|}
\hline $\begin{array}{l}\text { Mayo } \\
\text { Maslow } \\
\text { Mc. Gregor } \\
\text { Herzberg }\end{array}$ & $\begin{array}{l}\text { Humanização e manipulação do trabalho. } \\
\text { Hierarquia das necessidades. } \\
\text { Teoria x e Teoria Y aplicadas ao trabalho. } \\
\text { Fatores básicos e motivacionais do trabalho. }\end{array}$ \\
\hline $\begin{array}{l}\text { Friedman }(1960) \\
\text { Braverman }(1973)\end{array}$ & $\begin{array}{l}\text { O trabalho em migalhas. } \\
\text { A degradação do trabalho no século XX. }\end{array}$ \\
\hline $\begin{array}{l}\text { Emery }(1964,1976) \\
\text { Trist }(1978) \\
\text { Jacques }(1978)\end{array}$ & $\begin{array}{l}\text { O trabalho apresenta variedades e é desafiador; traz aprendizagem } \\
\text { contínua; permite autonomia e decisão; é reconhecido; traz contribuição } \\
\text { social; pode ser usado como uma defesa contra a angústia. }\end{array}$ \\
\hline $\begin{array}{l}\text { MOW (Meaning of work - 1987) } \\
\text { Metodologia de estudo do } \\
\text { significado do trabalho }\end{array}$ & $\begin{array}{l}\text { O trabalho acrescenta valor a alguma coisa - Padrão A } \\
\text { O trabalho é central na vida das pessoas - Padrão B } \\
\text { O trabalho é atividade/benefício para os outros - Padrão C } \\
\text { O trabalho não é agradável - Padrão D } \\
\text { O trabalho é exigente física e mentalmente - Padrão E } \\
\text { O trabalho é uma atividade regular remunerada - Padrão F }\end{array}$ \\
\hline $\begin{array}{l}\text { Morin, E. (1996, 1997, 2001, } \\
\text { 2002) } \\
\text { Aplicação do MOW }\end{array}$ & $\begin{array}{l}\text { O trabalho é eficiente e produz um resultado útil } \\
\text { Há prazer na realização da tarefa. } \\
\text { O trabalho permite autonomia; é fonte de relações humanas satisfatórias; } \\
\text { mantém as pessoas ocupadas. } \\
\text { O trabalho é moralmente aceitável. }\end{array}$ \\
\hline $\begin{array}{l}\text { Gorz (1980) Offe (1984) } \\
\text { Habermas (1986) } \\
\text { Rifkin (1994) } \\
\text { Antunes (1995) }\end{array}$ & $\begin{array}{l}\text { As transformações do trabalho no contexto da terceira revolução } \\
\text { industrial. } \\
\text { O debate sobre a perda da centralidade do trabalho no pensamento social e } \\
\text { econômico. }\end{array}$ \\
\hline Castells (2004) & O trabalho flexível e a sociedade em rede \\
\hline Vasapollo (2005) & Trabalho atípico \\
\hline
\end{tabular}

Fonte: Stefano e Nogueira (2006). Transcrição parcial.

Weber (1970) traz uma discussão entre o homem religioso e o econômico, que demonstra o empresário austero, que vivia do seu trabalho; Locke entendia o trabalho como a origem da propriedade individual e a fonte de todo valor econômico, base do liberalismo que mais tarde encontra em Adam Smith o nascimento do pensamento econômico clássico, para o qual o trabalho era o elemento regulador da riqueza das nações, porém era uma atividade sem alma.

O trabalho apresenta, nas diferentes culturas, significados distintos e conteúdos que variam. Entretanto, nas sociedades civilizadas, o trabalho tem em comum duas dimensões principais: o sentido de realização de uma obra e reconhecimento social e o significado de esforço, dor, sofrimento. Pode-se dizer, portanto, que o trabalho tem duas forças que movem o homem: a luta pela sobrevivência e a necessidade de inserção social. Segundo Carmo (1997, p.15), "pode-se definir trabalho como toda atividade realizada pelo homem civilizado que transforma a natureza pela inteligência”.

Os resultados das pesquisas realizadas pelos cientistas do grupo Mow (1987) citado por Oliveira, Piccinini, Fontoura e Schweig (2004), mostraram que o trabalho pode assumir desde uma condição de neutralidade até a de centralidade na identidade pessoal e social. Ele é 
essencial na vida das pessoas, e estas por sua vez, buscam ao mesmo tempo, utilidade para suas atividades dentro da organização e para a sociedade. Indicaram ainda que, valores como variedade na natureza das tarefas, aprendizagem, autonomia, reconhecimento acrescido aos aspectos básicos da sobrevivência e segurança, são fundamentais para que o trabalho tenha sentido.

É interessante também a classificação utilizada por Morin, Tonelli e Pliopas (2003) que definem o trabalho e seus sentidos relativos: i) ao indivíduo, ii) à organização e iii) à sociedade.

A dimensão individual contempla aspectos que remetem ao trabalho e seus sentidos para o indivíduo, apresentados em uma ordem decrescente de subjetividade: coerência, alienação, valorização, prazer, desenvolvimento, sobrevivência e independência. Quanto à dimensão organizacional, são aspectos ligados à utilidade, organização do trabalho e relações interpessoais no ambiente de trabalho. Nesse aspecto, para um trabalho fazer sentido ele deve alcançar resultados, valor para a empresa ou seus componentes. O trabalho que faz sentido, visto como sendo capaz de contribuir e ser útil para a sociedade aparece como fundamental, comparando-se com o aspecto de utilidade abordado na dimensão organizacional. Nota-se que na dimensão social ele adquire maior amplitude, pois se refere ao trabalho como contribuinte para o desenvolvimento não só da organização, mas da sociedade em geral.

Lima e Vieira (2005) apontam em seus estudos que uma interpretação do significado do trabalho seria baseada em vários aspectos: centralidade do trabalho na vida do sujeito, integração do sujeito com o trabalho, interferência mútua das diversas esferas da vida e, principalmente, em duas dimensões - a da materialidade (diretamente ligada às condições objetivas de efetivação do trabalho, que se modifica em função da situação, podendo variar no decorrer de um mesmo dia ou de minutos, que supre a necessidade de sobrevivência) e a do valor (relacionada à percepção subjetiva e que transcende um determinado momento vivido e remete a uma compreensão ao longo de um processo maior, que é a vida, relacionada aos valores, à ética e à moral que são do sujeito e dele indissociáveis em qualquer esfera de sua vida).

Dessa forma, o significado do trabalho poderia mudar ao longo da vida do sujeito, de acordo com a dimensão material, pois ele é reflexo de como as condições exteriores são percebidas por cada um. Na dimensão valorativa, ele pode ou não mudar, e, em caso afirmativo, a mudança geralmente acontece em função de um amadurecimento pessoal que faz com que o sujeito perceba a vida diferente, podendo também modificar suas prioridades e 
valores e, assim, a posição do trabalho e o significado deste na sua vida, que também podem ser alterados.

Morin (2001) relata que diversas pesquisas foram realizadas pelo grupo Meaning of Work (MOW) em vários paises com mais de 14.700 indivíduos, encontrando-se seis padrões de definições de trabalho. Em todos, o salário constitui um elemento importante na definição, portanto para a maioria dos pesquisados, existem poucas diferenças entre trabalho e emprego.

De acordo com essas pesquisas os padrões A, B e C representam concepções positivas do trabalho e valorizam o caráter social do trabalho. Os padrões $\mathrm{D}$ e E correspondem às concepções negativas do trabalho (atividade que os indivíduos são obrigados a fazer para ganhar a vida) e o padrão F é uma condição neutra do trabalho. O quadro 29 sintetiza esses conceitos.

Quadro 29 - Padrões de definição do trabalho (MOW)

\begin{tabular}{|c|l|}
\hline Padrão & \multicolumn{1}{c|}{ Significados do Trabalho } \\
\hline A & $\begin{array}{l}\text { O trabalho é uma atividade, geralmente agradável, que acrescenta um valor a alguma coisa e } \\
\text { pela qual se tem que prestar conta dos resultados. }\end{array}$ \\
\hline B & $\begin{array}{l}\text { Definição mais comum: o trabalho é uma atividade que proporciona a quem o realiza um } \\
\text { sentimento de vinculação e que traz uma contribuição à sociedade. }\end{array}$ \\
\hline C & $\begin{array}{l}\text { O trabalho é uma atividade que beneficia aos outros, que traz uma contribuição para a sociedade } \\
\text { e que gera um valor agregado. }\end{array}$ \\
\hline D & $\begin{array}{l}\text { O trabalho é uma atividade não agradável, mas que deve ser realizada por alguém em um lugar } \\
\text { específico, sob a supervisão de outra pessoa. }\end{array}$ \\
\hline E & O trabalho é uma atividade desagradável, que comporta exigências físicas e mentais. \\
\hline F & $\begin{array}{l}\text { É uma atividade que segue um horário regular, em um local de trabalho e pela qual se recebe um } \\
\text { salário. }\end{array}$ \\
\hline
\end{tabular}

Fonte: Adaptado de Morin (2001, p.76). Transcrição integral.

As pesquisas do grupo MOW apontaram que cerca de 10,6\% dos respondentes são do padrão $A, 27,6 \%$ do $\mathrm{B}, 17,6 \%$ do $\mathrm{C}, 21,7 \%$ do $\mathrm{D}, 10,6 \%$ e do F são $11,9 \%$, ou seja, 55,8\% têm a concepção positiva do trabalho e 32,3\% têm o entendimento negativo do trabalho. Os demais são neutros.

De acordo com Fischer e Fleury (1992), as relações de trabalho constituem a forma de relacionamentos que se verifica entre os agentes sociais que são os trabalhadores, que detêm a força de trabalho e os empregadores, que detêm os meios de produção. Essas relações são determinadas pelas características das relações sociais, econômicas e políticas da sociedade.

Nesse sentido, Nogueira (2002) aprofunda o entendimento das relações de trabalho, afirmando que estas abrangem o conjunto de arranjos institucionais e informais que modelam e transformam as relações entre capital e trabalho em suas diversas dimensões na complexa formação social e econômica capitalista, isto é, pela contradição entre o desenvolvimento das 
forças produtivas tecnológicas e do trabalho e as relações sociais de produção. As relações sociais e de trabalho são influenciadas pela cultura nacional e organizacional.

O mesmo autor relata que as relações de trabalho na perspectiva da gestão e dos gestores, onde o controle é a palavra-chave, se apresenta de diversas formas como por meios interpessoais, científicos, burocráticos, comportamentais e tecnológicos. As relações de trabalho na perspectiva do trabalho e dos trabalhadores a ênfase são nas ações coletivas dos trabalhadores, em particular o sindicalismo.

Nogueira (2002) afirma que o sistema brasileiro de relações de trabalho está baseado na persistência do regime tutelar fundamentado no controle e na intervenção do Estado sobre as relações entre trabalho e capital.

Conforme o mesmo autor são diversos os fatores que explicam a evolução das relações de trabalho como: fatores econômicos (inflação-estabilização, abertura de mercado e globalização); fatores tecnológicos (automação, toyotismo, CCQ, células e trabalho em grupo); fatores políticos (democratização e a constituição de 1988, e o fim do socialismo real); aspectos propriamente sindicais (novo sindicalismo e consolidação das centrais sindicais).

O quadro 30 sintetiza as principais características das mudanças no sistema de relações de trabalho no Brasil.

Quadro 30 - Mudanças no sistema brasileiro de relações de trabalho

\begin{tabular}{|c|c|c|}
\hline $\begin{array}{l}\text { Antes de } \\
1930\end{array}$ & $>$ & $\begin{array}{l}\text { Autonomia sindical e ausência de liberdade sindical. } \\
\text { A questão operária e trabalhista era caso de polícia. }\end{array}$ \\
\hline $1930-45$ & $\vec{\nu}$ & $\begin{array}{l}\text { Montagem gradual da legislação trabalhista e sindical corporativa. } \\
\text { Institucionalização da estrutura sindical oficial. } \\
\text { Controle dos sindicatos pelo Estado. } \\
\text { Criação da CLT, em } 1943 \text {. }\end{array}$ \\
\hline $1946-63$ & $>$ & $\begin{array}{l}\text { Período de redemocratização e persistência do corporativismo trabalhista. } \\
\text { Dinamização, mobilização e participação crescente dos sindicatos oficiais na vida } \\
\text { política nacional. } \\
\text { Politização do sindicalismo. }\end{array}$ \\
\hline $1964-77$ & $>$ & $\begin{array}{l}\text { Golpe militar e repressão aos sindicatos. } \\
\text { Exclusão política dos trabalhadores. } \\
\text { Fim da estabilidade e criação do FGTS. }\end{array}$ \\
\hline $1987-87$ & $\begin{array}{l}> \\
> \\
> \\
> \\
>\end{array}$ & $\begin{array}{l}\text { Renascimento do movimento sindical e surgimento do novo sindicalismo. } \\
\text { Explosão das greves. } \\
\text { Criação das centrais sindicais. } \\
\text { Implementação da negociação coletiva direta. } \\
\text { Presença das comissões de fábrica. } \\
\text { Sistema híbrido de relações de trabalho. }\end{array}$ \\
\hline $1988-94$ & & $\begin{array}{l}\text { Nova constituição e liberalização restrita dos sindicatos. } \\
\text { Livre associação sindical no setor público. } \\
\text { Fim da intervenção do Ministério do Trabalho nos sindicatos. } \\
\text { Manutenção do corporativismo. } \\
\text { Unicidade Sindical. } \\
\text { Monopólio de representação. } \\
\text { Justiça do trabalho. }\end{array}$ \\
\hline
\end{tabular}




\begin{tabular}{|l|l|l|}
\hline & $>$ Introdução da flexibilização nas relações de trabalho \\
\hline & $>$ Avanço da flexibilização das relações de trabalho. \\
& $>$ Explosão do trabalho informal e da precarização do trabalho. \\
& $>$ Terceirização do trabalho. \\
& $>$ Aumento do trabalho temporário e autônomo. \\
& $>$ Crise do sindicalismo. \\
\hline
\end{tabular}

Fonte: Nogueira (2002, p. 126). Transcrição integral.

Limongi-França (2007) relata que as relações de trabalho têm apresentado significativas evoluções caminhando para maior responsabilidade nas empresas. A nova tarefa é a busca do equilíbrio entre necessidades da força de trabalho e do capital. A normatização dessas regras é realizada por meio do direito do trabalho com seus instrumentos jurídiconormativos disponíveis que podem ser encontradas nas normas internacionais, estatais, autônoma (fruto da autonomia normativa de alguns atores sociais) e negociais (decorrentes de convenções coletivas e regulamentos internos das empresas).

A mesma autora destaca que os conflitos jurídicos relacionados às relações de trabalho envolvem a responsabilidade civil e criminal do empregador, principalmente ligadas ao não cumprimento da legislação trabalhista, acidentes do trabalho e patologias de origem ocupacional.

Nogueira (2007, p. 297) destaca as relações de trabalho em processos de internacionalização, a qual, no sentido amplo é entendida como "o conjunto das relações como mercado externo através da participação no comércio exterior, alianças estratégicas e tecnológicas entre empresas [...]”. A principal questão levantada pelo autor é: os processos de internacionalização favorecem a construção de um padrão de relações de trabalho?

Observa-se nos últimos anos no Brasil um crescimento nas exportações nacionais e a expansão dos negócios internacionais. Processo importante esse que gera empregos internos e divisas para o país. Desse modo, entende-se que a internacionalização e a intensificação do comércio internacional, contribuem para o debate da criação de empregos, renda, qualificação, condições de trabalho, negociações sindicais etc, ainda mais considerando as cadeias produtivas das exportações (NOGUEIRA, 2007).

O mesmo autor afirma que o modelo de análise das relações de trabalho deve ser o micro, meso, macro e hipermacro (global). Por um lado o debate da internacionalização e relações do trabalho demonstra benefícios sociais ao pólo do trabalho. Em outra análise, essa tendência de internacionalização reafirma a política concentradora e centralizadora do capital e da renda, não contribuindo com a diminuição da dívida social e da desigualdade brasileira. 
Nesse sentido, é pertinente a afirmação de Hitt, Ireland e Hoskisson (2005) sobre o mercado de trabalho administrativo, onde a escolha de altos executivos - especialmente os CEOs - é uma decisão organizacional crítica, pois tem importantes implicações para a organização. Diversas organizações desenvolvem sistemas de seleção para identificar executivos com potencial administrativo e de liderança estratégica. Considera-se o mercado de trabalho administrativo interno (dentro da organização, com seus postos de trabalho e carreira) e o externo (que é o conjunto de oportunidades de carreira para gerentes de organizações fora da empresa atual).

Dessa forma, foi fundamental o entendimento da evolução da liderança e sua orientação para resultados; a gestão estratégica de pessoas e suas visões: tradicional e transformada alinhada a estratégia organizacional; a gestão da cultura organizacional como propulsora dos valores e dos negócios; a gestão da qualidade de vida no trabalho e seus componentes na satisfação dos colaboradores e as relações no trabalho e seus diversos aspectos.

No próximo capítulo estão apresentados os métodos de pesquisa e suas etapas para consecução dos objetivos deste estudo. 
CAPÍTULO 4- MÉTODOS DE PESQUISA 
Este capítulo apresenta os métodos de pesquisa envolvendo: i) os estágios no processo de pesquisa; ii) as etapas e a classificação desse estudo; iii) o modelo para o estudo de caso; iv) o desenho da pesquisa; v) a definição dos sujeitos e os instrumentos de investigação; vi) as fontes de evidências e suas características; vii) a coleta de dados e as técnicas de tratamentos dos mesmos; viii) as limitações e as principais contribuições da pesquisa.

Há vários estágios fundamentais no processo de pesquisa que são comuns a todas as investigações com base científica, como se constata no quadro 31:

Quadro 31 - Estágios no processo de pesquisa

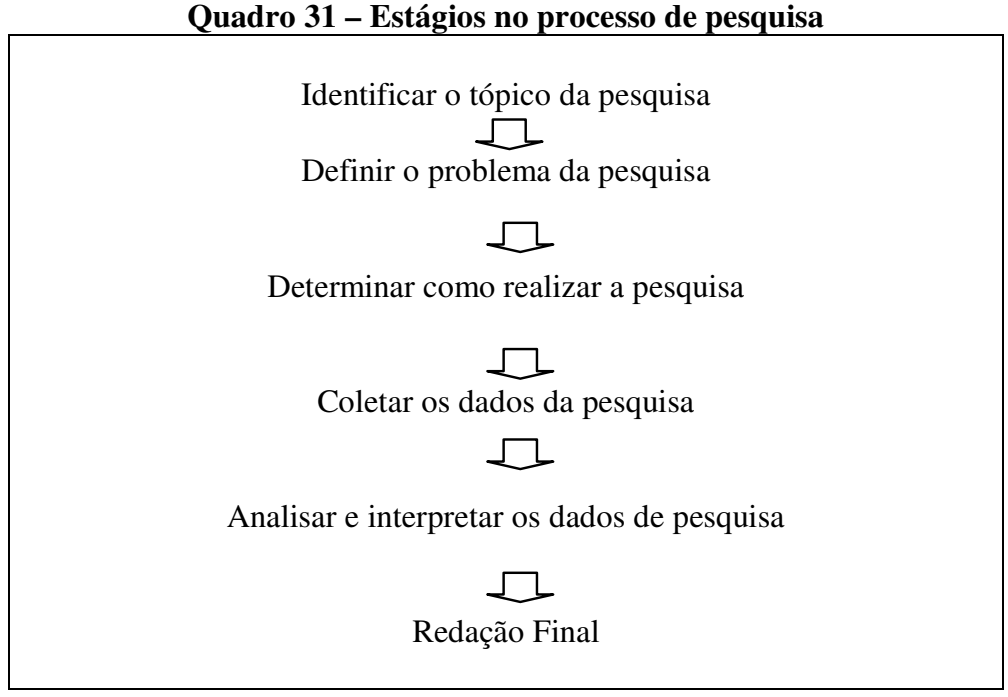

Fonte: Collis e Hussey (2005, p. 28). Transcrição parcial.

O quadro 31 apresenta um diagrama simplificado e organizado, como sendo uma visão tradicional e altamente estruturada do processo de pesquisa. De acordo com Collis e Hussey (2005) o processo de pesquisa não é tão simples, pois errar num estágio significa voltar a um estágio anterior e muitos deles se sobrepõem.

Nesse sentido, esta pesquisa foi dividida em quatro etapas, como segue:

Etapa 1: Planejamento da Pesquisa. Nesta fase inicial de planejamento foi desenhado o tipo de pesquisa a ser desenvolvido e os instrumentos de coleta de dados.

Etapa 2: Coleta de Dados. Esta etapa foi composta por duas fases, nas quais foram coletados dados documentais das instituições financeiras e dos sujeitos de pesquisa, nos meses de Maio, Junho, Julho, Agosto e Outubro de 2008.

Etapa 3: Análise dos dados. Esta fase caracteriza-se pela análise das informações das instituições financeiras, ou seja, da situação das mesmas e também dos sujeitos de pesquisa, 
realizando um comparativo dos resultados, visando atender os objetivos propostos. Foi desenvolvida nos meses de Julho, Setembro e Outubro de 2008.

Etapa 4: Conclusão. Constitui-se da elaboração de proposições e da redação final da tese. Esta fase foi realizada nos meses de Setembro e Outubro de 2008.

De acordo com o método proposto por Cooper e Schindler (1995), que compreende várias descrições diferentes para classificar uma pesquisa, esta envolve alguns aspectos:

a) Quanto aos fins, a pesquisa pode ser: exploratória, descritiva, explicativa, analítica ou preditiva. Esta pesquisa é caracterizada como exploratória, pois não proporcionou evidências conclusivas, proporcionando sugestões para pesquisas subseqüentes. A partir dos resultados é possível obter uma idéia preliminar das questões levantadas. Ela é descritiva, pois procurou descrever o comportamento dos fenômenos que são as percepções e entendimentos dos funcionários das instituições financeiras analisadas;

Quanto à dimensão tempo, nesta pesquisa foram utilizados os procedimentos da pesquisa ocasional única, pois as informações foram obtidas somente uma vez no tempo nos meses de Maio, Junho, Julho, Agosto, Setembro e Outubro de 2008.

b) Quanto aos meios de investigação, a pesquisa pode ser: pesquisa de campo, de laboratório, documental, bibliográfica, experimental, ex post facto, participante, pesquisa-ação e estudo de caso. Nesta pesquisa as fontes de dados utilizados foram os primários (pesquisa de campo com os gestores de gestão de pessoas e observação direta) e secundários (outras pesquisas realizadas; fundamentação teórica; folhetos, sites, documentos administrativos das instituições financeiras, entre outros);

c) Quanto à natureza das variáveis de pesquisa, foi eminentemente quantitativa, pois foram coletados dados de diversos gestores de pessoas, visto que foram analisados dois bancos múltiplos, onde o tratamento dos dados deve ocorrer como fato não isolado, pois as informações surgem em um ambiente dinâmico e permitem ao pesquisador buscar a essência dos fenômenos em estudo. Foi realizada também análise documental das instituições financeiras pesquisadas.

d) Quanto ao meio de investigação, o método utilizado foi o estudo de casos múltiplos e comparativos. Esse método permite uma comparação das informações provindas de várias fontes, através de processo de retroalimentação constante, entre coleta e análise de dados.

Segundo Yin (2005) o estudo de caso é uma metodologia particularmente apropriada para determinados tipos de problema, como aqueles em que pesquisa e teoria estão em estágio de formação ou aqueles baseados na prática, quando a experiência dos atores é importante. 
Apresentam ainda três razões que justificam o estudo de caso como estratégia mais apropriada, em dado contexto de pesquisa: (1) a possibilidade de estudar sistemas de informação no ambiente natural e de gerar teorias a partir da prática; (2) compreender a natureza e a complexidade do processo em jogo; e (3) a possibilidade de pesquisar uma área em que poucos estudos prévios tenham sido realizados.

O mesmo autor relata que o estudo de caso é uma pesquisa empírica que investiga fenômenos contemporâneos dentro do contexto da vida real, no qual os limites entre fenômeno e contexto não são claramente evidentes e as múltiplas fontes de dados são usadas.

Para Godoy (2006, p. 124) pode-se falar em diferentes tipos de estudos de caso descritivo, interpretativo e avaliativo. Essa pesquisa utilizou o estudo de caso interpretativo, pois além de conter uma rica descrição do fenômeno estudado, buscou encontrar padrões de dados e desenvolver categorias conceituais que possibilitem ilustrar, confirmar ou opor-se a suposições teóricas.

A estratégia de pesquisa que se pretende utilizar para alcançar os objetivos propostos é o estudo comparativo de múltiplos casos. Para Eisenhardt (1989, p. 534 - 535) o estudo de caso é uma estratégia de pesquisa que foca o entendimento da dinâmica presente dentro de cenários particulares, pode ser usado para atingir vários objetivos, para dar uma descrição, para testar ou gerar uma teoria.

São recomendados os casos múltiplos quando o pesquisador busca maior poder de generalização, por permitirem uma maior abrangência e cobertura das perguntas de pesquisa, de maneira que sejam obtidas as informações necessárias para as conclusões. As generalizações em estudos de caso são analíticas e não estatísticas, ou seja, o pesquisador generaliza dados específicos categorizando-os com base em teorias, que são amplas, e não considerando que o resultado encontrado estender-se-á a todo o universo (YIN, 2005).

Nesse sentido, é possível realizar conclusões mais precisas e confiáveis, motivo pelo qual se optou por esta metodologia. Por questões de clareza e simplicidade utiliza-se aqui o desenho metodológico para estudos de caso, adaptado de Gordon (2001). 


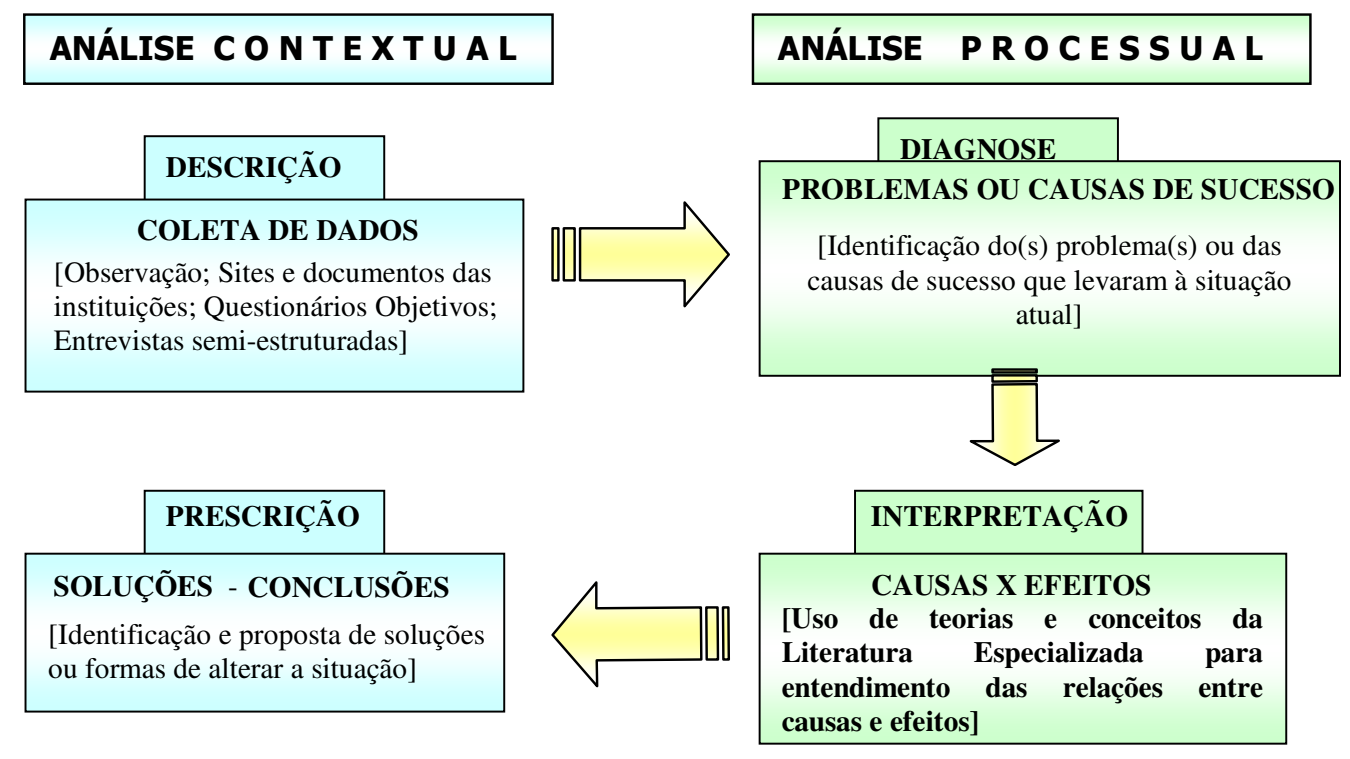

Ilustração 7 - Modelo para o Estudo de Caso

Fonte: GORDON (2001, p. 7). Transcrição parcial.

Os dois processos analíticos são compostos por um conjunto de quatro fases seqüienciais: Descrição - Diagnose - Interpretação - Prescrição. A descrição, que se apresenta, compreende a coleta dos dados e sua análise, numa perspectiva de contexto. As duas fases seguintes são processuais. A diagnose, na seção intitulada de Casos, compreende a identificação das causas envolvendo a visão e influência de pessoas, grupos e estruturas organizacionais. A fase da interpretação envolve a identificação das implicações dos fatores diagnosticados anteriormente, para o "comportamento" corrente da organização. Finalmente, a fase da prescrição refere-se às conclusões e sugestões de recomendação para a situação estudada.

\subsection{Desenho da Pesquisa}

O desenho da pesquisa constitui-se de um sistema de conceitos representativos do fenômeno em análise e de suas relações. A seguir apresenta-se na Ilustração 8 o desenho da pesquisa, considerando as variáveis independentes como o papel de liderança; as variáveis dependentes como os níveis de satisfação da qualidade de vida no trabalho e as variáveis intervenientes como as estratégias e políticas de gestão de pessoas, cultura organizacional e relações de trabalho. 


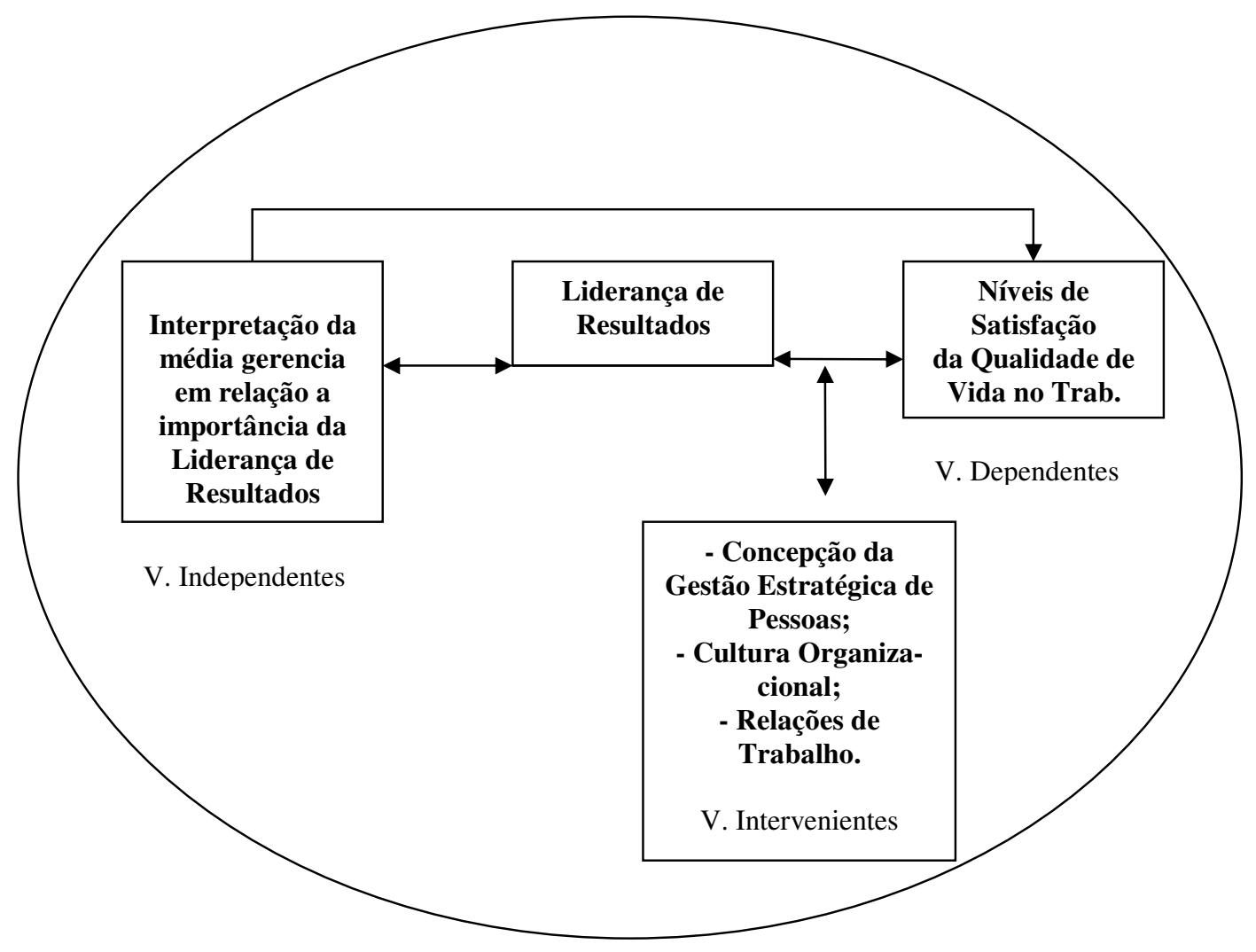

Ilustração 8 - Desenho da Pesquisa

Fonte: o pesquisador

As variáveis independentes são relacionados à interpretação dos gestores de pessoas em relação a importância da liderança orientada para resultados. As variáveis intervenientes baseiam-se na cultura organizacional e características institucionais, nas relações de trabalho e na concepção da gestão estratégica de pessoas que envolvem o modelo tradicional e de comprometimento. O tipo de liderança está relacionado à liderança embasada em resultados. As variáveis dependentes são relacionados aos níveis de satisfação da qualidade de vida no trabalho - fatores biológicos, psicológicos, sociais e organizacionais.

\subsection{Definição da amostra de pesquisa}

Vergara (2005, p. 50) relata que o universo de uma pesquisa é "um conjunto de elementos que possuem as características que serão objeto de estudo".

Quanto à determinação da população de pesquisa, representa o agregado de todos os casos que se enquadram num conjunto de especificações previamente estabelecidas. Neste estudo, é um único tipo de população (COOPER; SCHINDLER, 1995). 
A amostra de pesquisa foram os executivos, ou seja, os gestores de pessoas de duas Instituições Financeiras Internacionais e abrangeu uma amostra de setenta e três funcionários da instituição financeira denominada Alfa e noventa e cinco executivos da instituição Beta, totalizando cento e cinqüenta e oito funcionários.

Vergara (2005, p. 50) define amostra como "uma parte do universo a ser escolhida segundo algum critério de representatividade". Elas podem ser: a probabilística, que usa procedimentos estatísticos para defini-la e a não-probabilística.

A amostra foi selecionada através do método não-probabilístico por conveniência (tipicidade), ou seja, constituída pela seleção de elementos que o pesquisador considera representativos do universo estabelecido, pois permite que as organizações a serem pesquisadas sejam selecionadas em função da sua acessibilidade. Nessa pesquisa foram obtidas informações junto aos bancos selecionados, pois foram pesquisados os gestores de pessoas.

\subsection{Instrumentos de Pesquisa}

O instrumento de pesquisa é o meio pelo qual são coletados os dados de um determinado estudo, ele pode ser: questionário, entrevista, enquete, documentos, etc.

Neste estudo foram utilizados os questionários estruturados não disfarçados autopreenchidos (Apêndice 1), entrevista semi-estruturada (Apêndice 2) e o exame documental. Os dados secundários foram obtidos através de coleta de dados das instituições financeiras analisadas, outras pesquisas realizadas e revisão da literatura.

Os instrumentos de coleta de dados nada adiantam ou pouco contribuem quando não fundamentados adequadamente por uma teoria como descrito no item pressupostos conceituais e operacionais.

São apresentados e definidos todos os métodos utilizados na presente pesquisa e espera-se com essa combinação de técnicas atingir os objetivos anteriormente delineados, visando assim a contribuir para futuros estudos sobre o assunto e obter informações suficientes para corroborar com a área de estudo.

Para a realização da análise descritiva, os dados obtidos foram agrupados numa escala contínua. Os bancários avaliaram numa escala likert de cinco pontos os 14 fundamentos da liderança orientada para resultados, conforme o grau de importância avaliados pelos gestores de pessoas em 14 questões. Foram avaliados o grau de concordância numa escala likert de 
cinco pontos com as políticas e a gestão estratégica de pessoas com o público alvo dos bancos avaliados em 13 questões. O grau de satisfação deu-se numa escala likert de cinco pontos com as variáveis biológicas, psicológicas, sociais e organizacionais, em 20 questões afirmativas adaptado dos modelos conceituais. O quadro 32 sintetiza as categorias de análise e questões do instrumento de pesquisa.

Quadro 32 - Quadro síntese do questionário e categorias de análise

\begin{tabular}{|l|l|}
\hline \multicolumn{1}{|c|}{ Questões } & \multicolumn{1}{c|}{ Categorias de análise } \\
\hline $\begin{array}{l}02,03,04,05,06,07,08,09,10, \\
11,12,13,14 \text { e } 15\end{array}$ & $\begin{array}{l}\text { Características dos Líderes no seu setor e no banco, ou seja, importância } \\
\text { da Liderança orientada para resultados }\end{array}$ \\
\hline $\begin{array}{l}16,17,18,19,20,21,22,23,24, \\
25,26,27 \text { e } 28\end{array}$ & Nível de concordância com as políticas de Gestão de Pessoas \\
\hline $29,30,31,32$ e 33 & Nível de satisfação com os Aspectos Organizacionais \\
\hline $34,35,36,37$ e 38 & Nível de satisfação com os Aspectos Biológicos \\
\hline $39,40,41,42$ e 43 & Nível de satisfação com os Aspectos Psicológicos \\
\hline $44,45,46,47$ e 48 & Nível de satisfação com os Aspectos Sociais \\
\hline $01,49,50,51,52,53$ e 54 & Caracterização dos respondentes: cargo e dados demográficos \\
\hline
\end{tabular}

Fonte: o pesquisador

Foi utilizado um roteiro com cinco questões chaves. Elas foram apresentas no quadro 33 com o modelo conceitual que as fundamenta. O roteiro completo dos questionários estruturados encontra-se no Apêndice 1.

\section{Quadro 33 - Questões de Pesquisa e Modelo Conceitual} Questões de Pesquisa

a) Quais são os graus de importância da liderança orientadas para resultados dos profissionais da área de Gestão de Pessoas de duas Instituições Financeiras Internacionais? Liderança embasada em Resultados. Ulrich, Zenger e Smallwood (2000), Ulrich (2000).

b) Quais são os graus de concordância nas políticas de gestão estratégica de pessoas?

Gestão Estratégica de Pessoas. Albuquerque (1999, 2002)

c) Quais são os níveis de satisfação com os aspectos: organizacionais, biológicos, psicológicos e sociais dos executivos pesquisados?

Qualidade de Vida no Trabalho. Limongi-França $(1996,2004)$

Fonte: adaptado pelo pesquisador. Transcrição parcial

Os questionários visaram coletar as opiniões dos profissionais em relação a importância da liderança orientada para resultados; a concordância com as políticas de gestão estratégica de pessoas e os níveis de satisfação com os aspectos organizacionais, biológicos, 
psicológicos e sociais. Podem ocorrer respostas incompletas ou com subjetividade dos respondentes nos questionários de pesquisa.

Para complementar as informações da pesquisa quantitativa foram entrevistados na primeira semana do mês de Outubro dois funcionários do banco Alfa e três funcionários da instituição Beta com uma abordagem qualitativa. Os cinco participantes tinham respondido o primeiro instrumento de pesquisa.

Já o exame documental é importante, pois corrobora e valoriza as evidências originárias de outras fontes. Godoy (2006, p. 135) afirma que "o exame de documentos pode trazer contribuições importantes para o estudo de caso.” Os documentos podem ser materiais escritos (como recortes de jornais e outros textos, cartas, memorandos, relatórios e documentos administrativos), as estatísticas e outros tipos de registros ordenados em banco de dados e os elementos iconográficos (sinais, grafismos, imagens, fotografias e filmes).

Yin (2005) destaca a existência de seis fontes de evidências com seus pontos fortes e fracos, apresentado no quadro 34.

\begin{tabular}{|c|c|c|}
\hline Fontes de evidências & & \\
\hline Fomes ue eviuencidas & & \\
\hline Documentação & $\begin{array}{l}\text { Estável, discreta, exata e ampla } \\
\text { cobertura. }\end{array}$ & $\begin{array}{l}\text { Capacidade de recuperação, seletividade } \\
\text { tendenciosa, relato de vieses e acesso. }\end{array}$ \\
\hline $\begin{array}{l}\text { Registros em } \\
\text { arquivos }\end{array}$ & $\begin{array}{l}\text { [os mesmos mencionados para } \\
\text { documentação] } \\
\text { Precisos e quantitativos. }\end{array}$ & $\begin{array}{l}\text { [os mesmos mencionados para } \\
\text { documentação] } \\
\text { Acessibilidade aos locais devido a razões } \\
\text { particulares. }\end{array}$ \\
\hline Entrevistas & $\begin{array}{l}\text { Direcionadas - enfocam diretamente o } \\
\text { tópico do estudo de caso; } \\
\text { Perceptivas - fornecem inferências } \\
\text { causais percebidas. }\end{array}$ & $\begin{array}{l}\text { Vieses devido a questões mal-elaboradas, } \\
\text { respostas viesadas, ocorrem imprecisões, } \\
\text { reflexibilidade. }\end{array}$ \\
\hline Observações diretas & Realidade e contextuais & $\begin{array}{l}\text { Consomem muito tempo, seletividade, } \\
\text { reflexibilidade e alto culto. }\end{array}$ \\
\hline $\begin{array}{l}\text { Observação } \\
\text { participante }\end{array}$ & $\begin{array}{l}\text { [os mesmos mencionados para } \\
\text { observação direta] } \\
\text { Perceptiva em relação a } \\
\text { comportamentos e razões interpessoais }\end{array}$ & $\begin{array}{l}\text { [os mesmos mencionados para observação } \\
\text { direta] } \\
\text { Viesses devido à manipulação dos eventos } \\
\text { por parte do pesquisador }\end{array}$ \\
\hline Artefatos físicos & $\begin{array}{l}\text { Capacidade de percepção em relação a } \\
\text { aspectos culturais; capacidade de } \\
\text { percepção em relação a operações } \\
\text { técnicas }\end{array}$ & $\begin{array}{l}\text { Seletividade; } \\
\text { Disponibilidade. }\end{array}$ \\
\hline
\end{tabular}

Fonte: Yin (2005, p. 113). Transcrição integral.

Nessa pesquisa foram utilizadas as fontes de evidências como outras pesquisas realizadas; fundamentação teórica; folhetos, sites, documentos administrativos das instituições financeiras, entre outros. As fontes de evidências podem ser reunidas em três grupos principais: observação, entrevistas e documentos (YIN, 2005). 


\subsection{Coleta dos dados}

A coleta de dados, não é um processo acumulativo e linear, cuja freqüência, controlada e mensurada permite ao pesquisador estabelecer leis e prever fatos. Quanto ao método em sentido específico, foi utilizado o levantamento de dados.

São diversos os critérios que justificam a seleção do local do estudo e sujeitos de pesquisa. Em relação ao local do estudo foi a relevância do setor bancário brasileiro, pois representa aproximadamente $10 \%$ do PIB nacional. As oito primeiras Instituições Financeiras em ativos totais representam mais de $70 \%$ do segmento bancário. Destas selecionou-se duas Instituições Financeiras Internacionais com agências e sede administrativa no Brasil, entre as dez maiores instituições. Elas foram selecionadas por terem alcance internacional e atuarem em diversos continentes.

Em relação aos sujeitos de pesquisa, destacam-se os bancários que atuam em cargos gestores de pessoas, pois são agentes intermediários entre as intenções dos altos executivos (nível estratégico) que reproduzem as estratégias organizacionais, e as ações dos gerentes das agências bancárias (nível operacional). O critério para a seleção do público-alvo foi o método não-probabilístico por conveniência, ou seja, escolhidos aleatoriamente por acessibilidade.

Em relação à coleta de dados destacam-se os seguintes procedimentos:

1-) Foi realizado um teste-piloto antes da coleta de dados no mês de Março de 2008 com três gestores de pessoas de uma instituição financeira da cidade de Guarapuava/PR (Brasil). De acordo com Cooper e Schindler (1995) o teste-piloto é utilizado para detectar pontos fracos no planejamento ou na instrumentação, ou seja, para se verificar as etapas e instrumentos da pesquisa de campo.

2-) $\mathrm{Na}$ instituição financeira Alfa foram enviados via e-mail (Internet) para todos os executivos - gestores de pessoas da área - uma mensagem explicando os objetivos da pesquisa e o questionário para preenchimento. Na seqüência o funcionário deveria enviar as respostas diretamente para o e-mail do pesquisador, onde se obteve um retorno de sessenta e três questionários válidos, dos cento e sessenta enviados, com uma margem de confiança de $93,0 \%$;

3-) $\mathrm{Na}$ instituição Beta foram distribuídos pessoalmente pelo pesquisador os questionários impressos aos funcionários da área na sede do banco no Brasil e recolhidos no dia seguinte, obtendo-se um retorno de noventa e cinco questionários válidos, dos cento e quarenta e oito entregues, com uma margem de confiança de $94,8 \%$. 
4-) Foram agendadas e realizadas entrevistas na primeira semana do mês de Outubro com dois funcionários do banco Alfa (entrevistado 1 e 2) e três funcionários da instituição Beta (entrevistado 3, 4 e 5) visando complementar as informações e lacunas da primeira pesquisa. As entrevistas semi-estruturadas duraram em média cinqüenta minutos com cada colaborador. As respostas obtidas foram anotadas nos roteiros estruturados de entrevistas. Anotaram-se também as impressões das entrevistas no instrumento adaptado de Flick (2005) Apêndice 3.

Quadro 35 - Perfil dos Entrevistados

\begin{tabular}{|l|c|c|c|c|c|c|}
\hline Entrevistado & Gênero & Idade & $\begin{array}{c}\text { Tempo de } \\
\text { Empresa }\end{array}$ & $\begin{array}{c}\text { Data da } \\
\text { Entrevista }\end{array}$ & $\begin{array}{c}\text { Duração da } \\
\text { Entrevista }\end{array}$ & Local da Entrevista \\
\hline Entrevistado 1 & $\mathrm{M}$ & 38 & 20 anos & $07 / 10 / 2008$ & 45 minutos & Estado do Paraná \\
\hline Entrevistado 2 & $\mathrm{F}$ & 26 & 5 anos & $08 / 10 / 2008$ & 30 minutos & Estado do Paraná \\
\hline Entrevistado 3 & $\mathrm{M}$ & 51 & 5 anos & $09 / 10 / 2008$ & 60 minutos & Estado de São Paulo \\
\hline Entrevistado 4 & $\mathrm{F}$ & 48 & 25 anos & $09 / 10 / 2008$ & 60 minutos & Estado de São Paulo \\
\hline Entrevistado 5 & $\mathrm{F}$ & 35 & 11 anos & $09 / 10 / 2008$ & 45 minutos & Estado de São Paulo \\
\hline
\end{tabular}

Fonte: o pesquisador

São apresentados e definidos todos os métodos utilizados na presente pesquisa e espera-se com essa combinação de técnicas se alcance os objetivos anteriormente delineados, visando assim, a contribuir para futuros estudos sobre o assunto e obter informações suficientes para corroborar com a área de estudo.

O detalhamento da coleta de dados, com a instituição financeira, o período de realização, o instrumento de pesquisa e o tipo de pesquisa apresenta-se no quadro 36.

Quadro 36 - Etapas da Coleta de Dados
\begin{tabular}{|l|l|l|l|}
\hline Instituição Financeira & \multicolumn{1}{|c|}{ Período de Realização } & \multicolumn{1}{c|}{ Instrumento } & Tipo de Pesquisa \\
\hline Banco Alfa S/A & Maio e Junho de 2008 & Questionários & Quantitativa \\
\hline Banco Beta S/A & Agosto de 2008 & Questionários & Quantitativa \\
\hline Bando Alfa e Beta S/A & Outubro de 2008 & Entrevistas & Qualitativa \\
\hline
\end{tabular}

Fonte: o pesquisador

\subsection{Técnicas de tratamento dos dados}

Visando garantir a objetividade e a qualidade dos resultados, Yin (2005) recomenda alguns cuidados na análise de dados: a) mostrar que a análise está baseada em todas as evidências relevantes; b) incluir o maior número possível de interpretações rivais na análise; e c) orientar o aspecto mais significativo do estudo.

Os dados primários foram tratados utilizando o software "R", versão 2.7.1. O "R" é um software gratuito para elaboração de gráficos e computação estatística. O programa oferece 
diversas técnicas gráficas e estatísticas, modelos lineares e não lineares, testes estatísticos clássicos, análises de séries, classificação, entre outras. O programa produz diagramas com qualidade de publicações profissionais, incluindo símbolos matemáticos e fórmulas quando necessário (THE R PROJECT FOR STATISTICAL COMPUTING, 2008).

De acordo com a mesma fonte, o "R" é um pacote integrado de softwares para facilitar o trabalho com dados, cálculos e exibição de gráficos. As ferramentas incluem um gerenciador de dados e armazenamento, operadores para cálculos em exibições (matrizes em particular), uma coleção de ferramentas para análise de dados, facilidades para exibição recursos de programação para usuários avançados.

No tratamento dos dados foram realizadas a caracterização geral das instituições financeiras pesquisadas e as análises dos resultados dos questionários estruturados; foram apresentadas as características demográficas; efetuaram-se as análises descritivas Unidimensional e Bidimensional dos aspectos: liderança; gestão de pessoas; qualidade de vida no trabalho com aspectos organizacionais, biológicos, psicológicos e sociais; desenvolveu-se a matriz de correlação de SPEARMAN; apresentou-se o mapa de correlação de PEARSON das variáveis de QVT com liderança e gestão de pessoas foram desenvolvidas: a análise fatorial; as relações multivariadas e os testes de hipóteses para dados categorizados.

Para uma avaliação da pertinência dos itens dentro do mesmo fator e verificar sua confiabilidade, foram calculados os Alfas de Cronbach. Esta análise permite inferir se o instrumento demonstra confiabilidade.

\subsection{Limitações do estudo}

A presente pesquisa restringiu-se à duas instituições financeiras internacionais selecionadas denominadas por sigilo, conforme solicitação das mesmas como Banco Alfa e Banco Beta. Dessa forma, os resultados não poderão ser generalizados para outras Instituições Financeiras do sistema financeiro brasileiro ou mundial.

As limitações desse estudo foram ser em relação ao tamanho das amostras de pesquisa, visto que os profissionais respondentes não representam o universo de pesquisa, portanto, os resultados não podem ser generalizados para todos os bancários desses bancos e do setor financeiro internacional.

A análise foi realizada somente em relação aos gestores de pessoas das instituições financeiras selecionadas, portanto não são abrangentes em relação à todos os níveis hierárquicos dessas organizações. 


\subsection{Contribuições da pesquisa}

Esse estudo poderá trazer contribuições de ordem teórica e prática. Cita-se na perspectiva teórica a contribuição para o entendimento dos fundamentos e evolução da liderança no contexto organizacional, as relações de poder, os tipos de cultura organizacional e suas diferenças, a gestão estratégica de pessoas, o bem-estar organizacional e qualidade de vida no trabalho e as relações de trabalho. Esses construtos são encontrados originalmente na Psicologia, na Sociologia, na Filosofia, na História, na Economia, no Direito e na Administração.

As contribuições práticas esperadas são relacionadas com o maior entendimento dos sujeitos de pesquisa particularmente de instituições financeiras e suas relações com as variáveis de pesquisa. Isso poderá revelar algumas práticas entre os pesquisados e suas organizações.

4.8 Síntese dos métodos de pesquisa

Apresenta-se no quadro 37 a síntese dos métodos de pesquisa, envolvendo seus fins e características, a dimensão do tempo, a natureza dos dados/variáveis, os meios de investigação, os sujeitos de pesquisa, os critérios de seleção do público-alvo, os instrumentos de pesquisa, a coleta de dados e as técnicas de análises utilizadas.

Quadro 37 - Síntese dos métodos da pesquisa desta Tese

\begin{tabular}{|l|l|}
\hline Categoria/Aspectos & Etapas \\
\hline Objetivo Geral & $\begin{array}{l}\text { Analisar o grau de importância da liderança orientada para resultados na percepção } \\
\text { dos profissionais da área de Gestão de Pessoas de duas Instituições Financeiras } \\
\text { Internacionais que atuam no Brasil e suas relaçóes com a Gestão Estratégica de } \\
\text { Pessoas e com os níveis de satisfação dos aspectos: organizacionais, biológicos, } \\
\text { psicológicos e sociais, dos executivos participantes. }\end{array}$ \\
\hline $\begin{array}{l}\text { Fins da pesquisa - } \\
\text { características }\end{array}$ & Exploratório e descritiva. \\
\hline $\begin{array}{l}\text { Dimensão do tempo } \\
\text { Natureza dos } \\
\text { Dados/Variáveis }\end{array}$ & $\begin{array}{l}\text { Ocasional única realizada nos meses de Maio a Outubro de 2008. } \\
\text { com os gestores de pessoas e observação direta) e secundários (outras pesquisas } \\
\text { realizadas; fundamentação teórica; folhetos, sites, documentos administrativos das } \\
\text { instituições financeiras, entre outros). }\end{array}$ \\
\hline $\begin{array}{l}\text { Meio de Investigação } \\
\text { sujeitos de pesquisa }\end{array}$ & Casos Múltiplos e comparativos. Casos interpretativos. \\
\hline Amostra da Pesquisa & Bancos de atuação internacional entre os dez maiores (ativos totais) no Brasil. \\
\hline
\end{tabular}




\begin{tabular}{|l|l|}
\hline & $\begin{array}{l}\text { amostra de sessenta e três executivos do Alfa e noventa e cinco do Beta, totalizando } \\
\text { cento e cinqüenta e oito funcionários dessas organizações. }\end{array}$ \\
\hline $\begin{array}{l}\text { Critérios de seleção do } \\
\text { público-alvo }\end{array}$ & Método não-probabilístico por conveniência (tipicidade). \\
\hline $\begin{array}{l}\text { Instrumento de } \\
\text { Pesquisa }\end{array}$ & $\begin{array}{l}\text { Questionário estruturado de auto-relato - Apêndice 1. } \\
\text { Entrevista semi-estruturada - Apêndice 2 e ficha de documentação da entrevista - } \\
\text { Apêndice 3. } \\
\text { Análise documental das instituições financeiras. }\end{array}$ \\
\hline Coleta dos Dados & $\begin{array}{l}\text { Banco Alfa, enviados questionários via e-mail (Internet). } \\
\text { Na instituição Beta foram distribuídos pessoalmente pelo pesquisador os } \\
\text { questionários impressos aos funcionários. } \\
\text { Realizadas cinco entrevistas semi-estruturadas complementares. } \\
\text { Levantamento de dados. Análise documental das instituições financeiras e } \\
\text { documentos relevantes. }\end{array}$ \\
\hline $\begin{array}{l}\text { Técnica de Análise dos } \\
\text { Dados }\end{array}$ & $\begin{array}{l}\text { Os dados primários foram tratados utilizando a análise descritiva Unidimensional e } \\
\text { Bidimensional dos aspectos pesquisados. Foi desenvolvida a análise de Variância } \\
\text { Multivariada; Matriz de Correlação de Spearman; Mapa de correlação de Pearson } \\
\text { das variáveis; cargas fatoriais e método de regressão. Foi também calculado o Alfa } \\
\text { de Cronbach e os Testes de hipóteses para dados categorizados. }\end{array}$ \\
\hline
\end{tabular}

Fonte: o pesquisador

No próximo capítulo estão apresentadas as análises e discussões dos resultados da pesquisa de campo e análise documental. 
CAPÍTULO 5- ANÁLISE E DISCUSSÃO DOS RESULTADOS 
Neste capítulo estão apresentadas as análises e discussões dos resultados da caracterização das instituições financeiras estudadas; os resultados da pesquisa quantitativa; as características demográficas dos respondentes; as análises descritivas; a matriz de correlação de SPEARMAN; o mapa de correlação de PEARSON das variáveis de QVT com liderança e gestão de pessoas; a análise fatorial e as relações multivariadas.

\subsection{Caracterização das Instituições Financeiras Analisadas}

As duas Instituições Financeiras analisadas são de capital internacional e suas matrizes mundiais são sediadas na Europa. A seguir apresenta-se uma breve caracterização das mesmas, as quais não terão seus nomes divulgados seus nomes por solicitação dos diretores da área de Recursos Humanos, portanto, foram denominados de Banco Alfa e Banco Beta.

\section{a) Banco Alfa}

Foi fundado no século XIX e sediado na Europa, sendo uma das maiores organizações de serviços financeiros e bancários do mundo. A rede internacional do Grupo Alfa é composta por dez mil escritórios em 83 países e territórios na Europa, Ásia-Pacífico, Américas, Oriente Médio e África.

O Grupo Alfa emprega aproximadamente 315 mil colaboradores e atende mais de 128 milhões de clientes. Com ações cotadas nas Bolsas de Londres, Hong Kong, Nova Iorque, Paris e Bermuda, a Alfa Holding tem mais de 200 mil acionistas em cerca de 100 países e territórios.

O Banco Alfa oferece aos seus clientes uma rede global, interligada por tecnologia de ponta e uma ampla gama de serviços financeiros: banco de varejo, commercial, corporate, investment e private banking; trade services; cash management; serviços de tesouraria e mercados de capital; seguros e previdência; empréstimos e financiamentos; fundos de pensão, entre outros.

No Brasil o Banco Alfa segue uma série de princípios e valores incluindo padrão ético, justo e responsável no tratamento dos negócios. A política de qualidade do banco visa consolidar o desenvolvimento da empresa em bases sólidas e seguras, sempre com foco no cliente.

A carteira atual do Banco Alfa no Brasil é de aproximadamente 2,9 milhões de clientes pessoa física e 312.948 mil clientes pessoa jurídica. Está presente em 565 municípios 
brasileiros, com 933 agências, 457 postos de atendimento bancários, 949 postos de atendimento eletrônicos e 2.000 ambientes de auto-atendimento, com 5.673 caixas automáticos. Os clientes contam no Brasil com 27 mil caixas automáticos na rede compartilhada com outros bancos no Brasil. Em 2007, obteve lucro líquido de R \$ 1,24 bilhão, o maior resultado desde o início de suas operações no país.

O Grupo financeiro Alfa lidera o ranking Forbes 2000 das maiores companhias mundiais, sendo classificada como a maior empresa do mundo. Essa é a primeira vez que uma companhia fora dos Estados Unidos assume a liderança desde o lançamento da lista em 2004. O índice anual examinou empresas de 26 setores de atividade em 60 países, classificando-as sob critérios de vendas, lucros, ativos e valor de mercado.

O Grupo Alfa ficou entre os cinco melhores em desempenho no setor bancário, tendo atingido um crescimento médio anual de $26 \%$ em receita bruta e de $31 \%$ em lucro líquido nos últimos cinco anos.

No total, as companhias da Forbes 2000 respondem atualmente por uma receita bruta de US 30 trilhões, por lucros de US 2,4 trilhões, por ativos de USD 119 trilhões e US 39 trilhões de valor de mercado. Essas companhias empregam mais de 72 milhões de pessoas ao redor do mundo (FORBES, 2008).

Considerando-se o número de companhias, que são 315, o setor bancário registra a maior presença na Forbes 2000. O setor bancário também lidera em ativos, com totais de US 58,3 trilhões, e lucros com US 398 bilhões. As 123 companhias que operam no setor de petróleo e gás, lideram todos os setores com receitas globais de US 3,76 trilhões, assumindo o segundo lugar em total de lucros, com US 386 bilhões.

Os Estados Unidos ainda lideram em termos geográficos, mas a sua influência está em queda, com 61 participantes a menos que no ano passado. Por outro lado, a China, a Índia e o Brasil estão acrescentando rapidamente companhias à lista (FORBES, 2008).

Missão do Banco Alfa

"Garantir a excelência na entrega de produtos e serviços financeiros, maximizando valor para clientes e acionistas."

Visão

"Ser o melhor grupo financeiro do Brasil em geração de valor para clientes, acionistas e colaboradores."

Valores

"Nossa conduta deve refletir os mais altos padrões de ética. 
Nossa comunicação deve ser clara e precisa.

Nosso gerenciamento deve ser em equipe, consistente e focado.

Nosso relacionamento com clientes e colaboradores deve ser transparente e baseado na responsabilidade e confiança entre as partes”.

Qualidade

O Grupo Alfa entende que a qualidade de seus produtos e serviços é obtida pela prática coerente dos seus princípios e valores. O objetivo maior é a satisfação dos clientes em todas as suas necessidades. Uma rede de colaboradores é responsável por disseminar o conceito de qualidade para todas as unidades do Grupo Alfa no Brasil, garantindo a excelência no atendimento e a implementação de ações inovadoras e de melhorias.

A comunicação com os clientes também é um ponto fundamental do Bando Alfa que possui canais para críticas ou reclamações a respeito da qualidade dos produtos e serviços, com o SAC - Serviço de Apoio ao Cliente, através de: Ferramentas Úteis - Fale Conosco.

Após essa breve caracterização, são apresentadas as análises das duas entrevistas semiestruturadas realizadas com gestores de pessoas da instituição financeira Alfa, conforme roteiro estruturado que consta no Apêndice 2. Atribuiu-se um código para cada um dos entrevistados, para que não fosse possível sua identificação.

Em relação aos processos de gestão e o modelo da gestão estratégica de pessoas foram verificadas na instituição as práticas de recrutamento e seleção de pessoal, treinamento e desenvolvimento, cargos e salários, benefícios sociais, avaliação de desempenho e a higiene e segurança no trabalho, como se constata nas falas dos entrevistados:

Recrutamento e seleção é um programa transparente e muito bem estruturado, pois ocorre tanto internamente quanto externamente e é baseado na seleção por competências. Num primeiro momento é realizado por empresas de consultoria, devido ao grande número de inscritos e, na última etapa por profissionais preparados do próprio banco, os quais oferecem feedback aos candidatos não escolhidos. (Entrevistado 01)

Existem 4 centros de treinamento no país: São Paulo, Rio de Janeiro, Brasília e Paraná, todos eles com infra-estrutura de primeira: salas de treinamento, equipamentos adequados e informatizados, espaço para lazer e jogos, restaurante, lanchonete e hotel, entre outros.

O programa de treinamento e desenvolvimento do banco é referência, pois é um dos melhores, inclusive recebeu recentemente o prêmio E-Learning Brasil. Ele engloba treinamentos comportamentais, de liderança, técnicos e de ambientação, os quais podem ser presenciais, não-presenciais, Tv corporativa e E-Learning.

O planejamento é realizado no início de cada ano, onde são montados pacotes de treinamentos prontos e, para participar desses treinamentos existem determinados critérios que tem que ser atingidos. Tanto as pessoas podem se inscrever (desde que atendam os critérios estabelecidos) quanto as chefias podem indicar. 
Após a realização dos treinamentos são realizadas avaliações de reação dos colaboradores, através da percepção do treinando, do que ele vivenciou. (Entrevistado 01)

Os programas de cargos e salários são:

O programa acabou de passar por um alinhamento, onde as promoções passaram de vertical para horizontal, considerando as competências individuais dentro de cada banda. Esse alinhamento está pronto e em fase de testes para funcionamento em breve. (Entrevistado 01)

Em relação a remuneração, é insatisfatória, pois é um dos bancos que remunera menos. (Entrevistado 02)

Os benefícios sociais oferecidos aos colaboradores do banco:

Funcionários: Além dos benefícios convencionais, da remuneração variável, do programa de treinamento e da colaboração para qualificação (graduação e pós), existe um programa de assistência pessoal (físico, psicológico, financeiro, familiar e jurídico), além de um site aonde os colaboradores tem acesso a produtos com preços bem mais acessiveis.

Sociedade: Existe o Instituto Solidariedade que atua em todo o país e que prima pelo bem estar social, educação e inserção de crianças carentes na sociedade $e$ também projetos de sustentabilidade como por exemplo do Seguro de automóvel que contribui com o carbono neutro, onde são adquiridas determinadas cotas de reflorestamentos e proteção e recuperação de águas e nascentes de rios. (Entrevistado 01)

O sistema de avaliação de desempenho:

São realizadas duas reuniões por ano, uma a cada semestre, sendo uma no meio do ano para revisão e a outra no final do ano avaliando o desempenho individual e da equipe.

Existe um comitê responsável pela avaliação de todas as equipes com a geração de notas, as quais pontuam os colaboradores e equipes para o recebimento da remuneração variável. (Entrevistado 01)

Em relação à higiene e segurança no trabalho:

Existe a área de saúde ocupacional, responsável pelos exames (admissionais, demissionais e periódicos) e pelas campanhas de prevenção. (Entrevistado 02)

Dessa forma, entende-se que as políticas de gestão de pessoas desse banco estão estruturadas e visam o alinhamento entre a estratégia da instituição e a gestão de pessoas.

\section{b) Banco Beta}

O Grupo Beta é a primeira instituição financeira da Europa por capitalização em bolsa e o sétimo do mundo em lucro. Fundado no século XIX e sediado na Europa, tem $€ 885$ 
bilhões em ativos; administra mais de $€ 1$ trilhão em fundos, tem mais de 69 milhões de clientes, 11 mil agências, mais de 131 mil funcionários e está presente em 40 países.

É o principal grupo financeiro do seu país de origem na Europa e da América Latina e desenvolve uma importante atividade de negócios, região em que alcançou uma presença destacada no Reino Unido, bem como em Portugal. É líder em financiamento ao consumo na Europa, por meio do Grupo Beta, com presença na Alemanha, Itália, Espanha e em outros nove países europeus. No primeiro semestre de 2007, registrou lucro líquido de $€ 4,45$ bilhões, $39 \%$ a mais do que o registrado no mesmo período do ano anterior.

Na América Latina, o Grupo Beta é instituição financeira líder, administrando volumes de negócio de aproximadamente US\$ 200 bilhões (créditos, depósitos e fundos de investimento e de pensão) por meio de 4,4 mil agências. Em 2007, registrou lucro líquido de US $\$ 2,2$ bilhões. Esse desempenho representou $20 \%$ do ganho líquido global no período e destacou o Brasil, que respondeu por 35\% do resultado da região.

O Banco Beta é um dos maiores bancos privados estrangeiros no Brasil em ativos, reflexo da prática diária dos valores do Grupo: liderança, dinamismo e antecipação, fortaleza de balanço, inovação, orientação ao cliente e ética profissional. Está estruturado para oferecer um atendimento diferenciado e uma completa gama de produtos e serviços a clientes que precisem de um Banco forte no País e no exterior, atuando com eficiência e disponibilidade. A sinergia e a larga experiência do Grupo Beta, com sede mundial na Europa, permite compartilhar conhecimento e tecnologia de serviços, para aperfeiçoar constantemente sua atuação.

Na década de 1980, inaugurou sua primeira agência no Brasil. A seqüência de aquisições de vários e tradicionais bancos brasileiros, a partir dos anos 1990, também foi estrategicamente ponderada e planejada para levar o Banco Beta a uma posição de destaque. Esses acontecimentos, entre outros, levaram o Banco Beta a se tornar uma das principais instituições financeiras do mercado nacional. Atua em todos os segmentos do mercado financeiro e incorporou uma série de bancos ao longo dos últimos dez anos, com operações concentradas nas Regiões Sul e Sudeste, principais mercados financeiros nacionais.

O Banco Beta possui no Brasil ativos totais de R \$ 123,6 bilhões, R \$ 130,5 bilhões de captações totais, que incluem recursos de terceiros administrados, $\mathrm{R} \$ 34,3$ bilhões em depósitos e $\mathrm{R} \$ 52,1$ bilhões em fundos de investimentos, 8 milhões de clientes e conta com uma rede de 2.121 agências e postos de atendimento, 7.558 caixas eletrônicos e mais de 22 
mil funcionários em 31 de dezembro de 2007. No primeiro semestre de 2008, registrou $R \$$ 133,5 bilhões em ativos e encerrou o período com lucro de $\mathrm{R} \$ 830$ milhões.

Missão

"Desenvolver e consolidar uma franquia financeira líder no Brasil, por meio da criação de valor para os acionistas, clientes, funcionários e comunidades onde operamos."

Valores Corporativos

"Liderança: Vocação de liderança em todos os mercados onde estamos presentes, com as melhores equipes e com um consistente foco em clientes e resultados.

Dinamismo e Antecipação: Iniciativa e agilidade para descobrir e explorar as oportunidades de negócios, antes de nossos concorrentes e flexibilidade de adaptação às mudanças do mercado.

Fortaleza de balanço: A força do nosso balanço e a prudência na gestão de riscos são as melhores garantias da nossa capacidade de crescimento e de geração de valor para os nossos acionistas, a longo prazo.

Inovação: Procura constante de produtos, serviços e processos que atendam às necessidades dos clientes e nos permitam obter aumento de rentabilidade superior ao dos nossos concorrentes.

Orientação ao cliente: O cliente é o foco de nossa estratégia. Queremos melhorar de maneira contínua a captação, a satisfação e a vinculação de clientes, por meio de uma ampla oferta de produtos e serviços, sempre com a melhor qualidade.

Ética profissional: Além do cumprimento as Leis, dos Códigos de Conduta e das normas internas, exigi-se de todos os profissionais do banco atuar com a máxima honestidade e transparência, considerando-se sempre o interesse do Grupo e dos clientes acima da posição pessoa."

$\mathrm{Na}$ instituição Beta foram realizadas três entrevistas com gestores de pessoas, seguindo o roteiro de perguntas semi-estruturadas constante no Apêndice 2. Atribuiu-se um código para cada um dos pesquisados, para garantir o anonimato dos mesmos.

Foram verificados os processos e o modelo da gestão estratégica de pessoas na instituição e as práticas de recrutamento e seleção de pessoal, treinamento e desenvolvimento, cargos e salários, benefícios sociais, avaliação de desempenho e a higiene e segurança no trabalho.

Com relação ao recrutamento e seleção de colaboradores no Banco Beta, verificou-se: 
Inovar, principalmente quando se trata de recrutamento e seleção, é um pouco complicado, pois há um modus operandi no mercado, não só no setor, mas no mercado como um todo. Busca-se fazer benchmarking, mas acredita que as principais inovações são a tentativa de trabalhar com um sistema de recrutamento $e$ seleção híbrido, tratar da marca fazer Branding, e investir na imagem da empresa e a possibilidade de mobilidade que ela oferece são grandes vantagens competitivas. Também destacasse o recrutamento de universitários com potencial. (Entrevistado 3)

Acontecem constantes revisões e aprimoramentos.

É rigoroso e com várias etapas. Existe o recrutamento interno e externo. A seleção é em várias etapas. (Entrevistado 4)

\section{O processo de treinamento e desenvolvimento de pessoal:}

Exitem cursos à distância, treinamento interno net-cursos, nesse momento está sendo pago MBA e curso pós para dois funcionários da sua área, é lógico que é considerado a avaliação do funcionário e portanto nem todos tem investimento financeiro. Há muito estimulo por parte dos gestores para o autodesenvolvimento. (Entrevistado 3)

Há oportunidades internas, mas não há uma cultura para aproveitar os incentivos. (Entrevistado 4)

Há treinamento interno, oferece net-cursos, e, é recomendado que os gestores estimulem o funcionário. Na rede comercial há um programa chamado trilha de formação um programa específico de formação.

Os funcionários não conhecem não reconhecem estas oportunidades, pois querem incentivo financeiro para cursos de pós e idiomas. (Entrevistado 5)

\section{Os programas de cargos, salários e punições na instituição:}

A instituição não tem percepção da qualidade do sistema de recompensas. Do sistema de punições, acredita-se que considerem um processo justo, já que tem participação de todos os envolvidos. (Entrevistado 3)

Ainda se está na tentativa de equalizar salários para acompanhar a faixa de mercado, devido as diferentes políticas dos bancos que foram comprados.

A política precisa equalizar pendências (diferente faixas de salários para um mesmo cargo) para ser mais competitivo. (Entrevistado 4)

Com relação às recompensas ainda não se conseguiu ter equilíbrio e a implantação efetiva do plano. Quanto à punição há um código de ética claro, cursos obrigatórios quando se ingressa no banco (ex: prevenção de lavagem de dinheiro). As regras são claras. O sistema de recompensas não é bem visto pelo todo, fica muita coisa represada por causa dos processos de fusão. (Entrevistado 5)

\section{Os benefícios sociais oferecidos aos colaboradores:}

Não considerando a questão da previdência privada, com relação aos benefícios o banco está bem situado, há seguro de vida, complemento doença e outras políticas compatíveis com o mercado. Há também um programa de apoio pessoal pelo qual o funcionário tem acompanhamento psicológico 24 horas através de uma central, para auxiliar em qualquer tipo de situação, desde compras pessoais até conflitos de relacionamento com pares na organização. (Entrevistado 4)

O seguro de vida é bom, mas o banco não participa custeando o Plano de previdência privada. (Entrevistado 5) 
O sistema de avaliação de desempenho dos funcionários:

A ferramenta é boa, mas as pessoas ainda estão aprendendo a lidar com ela com mais seriedade. (Entrevistado 4)

Os programas de higiene e segurança no trabalho:

A área de saúde está sempre em inovação, atualmente vem sendo percebida como investimento. (Entrevistado 3)

O ambiente é agradável e os equipamentos adequados. A legislação é cumprida a risco. (Entrevistado 4)

Devido às fusões busca-se a estabilidade, a continuidade dos programas em todas as áreas. Quando se fala em fusão a primeira coisa é congelar o orçamento, aí todos têm dificuldade de fazer planejamento e efetivar os programas. (Entrevistado $5)$.

A instituição financeira Beta também possui a área de gestão de pessoas estruturada no nível estratégico. Nota-se pelas respostas das entrevistas certa insatisfação em várias políticas ou a falta das mesmas, como nos benefícios sociais, previdência complementar, remuneração e equidade salarial.

Após uma breve caracterização das instituições financeiras Alfa e Beta e da apresentação das percepções de alguns colaboradores sobre as políticas de recursos humanos das mesmas, apresenta-se as análises dos resultados da pesquisa quantitativa.

\subsection{Análises dos Resultados da Pesquisa Quantitativa}

Foram considerados sessenta e três questionários respondidos pelos funcionários da área de Gestão de Pessoas do Banco Alfa e noventa e cinco questionários do Banco Beta, totalizando cento e cinqüenta e oito questionários válidos. Estes questionários possuem somente questões fechadas. Algumas questões são de características demográficas, ou seja, para caracterização dos funcionários respondentes.

Foi realizada a análise descritiva dos aspectos: Liderança; Gestão de Pessoas; Qualidade de Vida no Trabalho com os Aspectos Organizacionais, Biológicos, Psicológicos e Sociais. Posteriormente foi desenvolvida a análise de Variância Multivariada, da Matriz de Correlação de Spearman, do Mapa de correlação de Pearson, das variáveis de QVT com Liderança e GEP, das cargas fatoriais e método de regressão para explicar a consistência de respostas e das categorias do questionário. São apresentados ainda o Alfa de Cronbach e os Testes de hipóteses para dados categorizados. 
Foram observados em praticamente todas as questões que alguns funcionários optaram por não responder determinados itens. Essa proporção não chegou a $5 \%$ e essa nãoinformação foi desconsiderada na mensuração dos resultados e análises.

Foi realizado o teste de Alfa de Cronbach, que mede a consistência interna do questionário de pesquisa de campo. Segundo Litwin (1995), o teste de confiabilidade é imperativo e mede o desempenho de um instrumento em uma dada população evitando o agrupamento de questões aparentemente relevantes. Os seguintes resultados foram obtidos: Alfa de Cronbach: 0,9551857, ou seja, existe consistência de respostas do instrumento de pesquisa e consistência das categorias do questionário.

A seguir são apresentadas as características demográficas dos funcionários pesquisados nos bancos Alfa e Beta.

\subsection{Características Demográficas}

Apresentam-se, nas tabelas 4 a 8, as características demográficas dos respondentes da pesquisa de campo por Instituição Financeira, envolvendo aspectos como: cargo atual (gerente ou supervisor, consultor interno, técnico, analista ou auxiliar, outro e não respondeu); gênero (masculino, feminino e não respondeu); faixa etária (até 30 anos, 31 a 35 anos, 36 a 40 anos, 41 a 45 anos, 46 a 50 anos, acima de 50 anos e não respondeu); escolaridade (até ensino médio completo, superior incompleto, superior completo, pós-graduação incompleto, pósgraduação completo e não respondeu) e número de dependentes (nenhum, um, dois, três, quatro ou mais e não respondeu).

Tabela 4 - Cargo dos Respondentes na Instituição Financeira

\begin{tabular}{|c|c|c|c|}
\hline Instituição & Cargo Atual & Quantidade & Percentuais \\
\hline \multirow{6}{*}{ Alfa } & Gerente ou Supervisor & 17 & $27,0 \%$ \\
\hline & Consultor Interno & 8 & $12,7 \%$ \\
\hline & Técnico, Analista ou Auxiliar & 24 & $38,1 \%$ \\
\hline & Outro & 8 & $12,7 \%$ \\
\hline & Não Respondeu & 6 & $9,5 \%$ \\
\hline & Total & 63 & $100,0 \%$ \\
\hline \multirow{6}{*}{ Beta } & Gerente ou Supervisor & 15 & $15,8 \%$ \\
\hline & Consultor Interno & 6 & $6,3 \%$ \\
\hline & Técnico, Analista ou Auxiliar & 51 & $53,7 \%$ \\
\hline & Outro & 5 & $5,3 \%$ \\
\hline & Não Respondeu & 18 & $18,9 \%$ \\
\hline & Total & 95 & $100,0 \%$ \\
\hline \multicolumn{2}{|r|}{ Total geral } & 158 & - \\
\hline
\end{tabular}

Fonte: Dados da pesquisa 
A tabela 4 identifica o cargo atual dos respondentes da pesquisa na Instituição Financeira que trabalha, podendo ser gerente ou supervisor, consultor interno, técnico, analista ou auxiliar, outro ou não respondeu. Os líderes formais são representados no cargo de gerente ou supervisor, representam aproximadamente 1/4 no banco Alfa e 1/6 no banco Beta. Nas duas instituições a maior parcela de participantes foram os técnicos, analistas ou auxiliares.

Segundo a Febraban (2007), há preocupação de 32\% dos bancos em monitorar seu quadro de pessoal para buscar um melhor equilíbrio entre o número de funcionários homens e mulheres nos cargos gerenciais. Todas as organizações pagam salários e concedem benefícios idênticos aos colaboradores que ocupem o mesmo nível hierárquico, independentemente de gênero, raça ou deficiência. Com relação a benefícios, como planos de saúde e odontológicos, $36 \%$ são estendidos a parceiros de colaboradores do mesmo sexo, de acordo com as vinte e oito instituições financeiras pesquisadas em 2006.

Tabela 5 - Distribuição dos Respondentes por Gênero na Instituição Financeira

\begin{tabular}{c|l|c|c}
\hline Instituição & \multicolumn{1}{|c|}{ Gênero } & Total & Percentuais \\
\hline \multirow{5}{*}{ Alfa } & Masculino & 26 & $41,3 \%$ \\
\cline { 2 - 4 } & Feminino & 37 & $58,7 \%$ \\
\cline { 2 - 4 } & Não Respondeu & 0 & $0,0 \%$ \\
\cline { 2 - 4 } & Total & $\mathbf{6 3}$ & $\mathbf{1 0 0 , 0 \%}$ \\
\hline \multirow{5}{*}{ Beta } & Masculino & 40 & $42,1 \%$ \\
\cline { 2 - 4 } & Feminino & 51 & $53,7 \%$ \\
\cline { 2 - 4 } & Não Respondeu & 4 & $4,2 \%$ \\
\cline { 2 - 4 } & Total & $\mathbf{9 5}$ & $\mathbf{1 0 0 , 0 \%}$ \\
\hline \multicolumn{2}{|c|}{ Fonte: Dados da pesquisa } \\
\hline
\end{tabular}

Fonte: Dados da pesquisa

$\mathrm{Na}$ tabela 5 está a distribuição por gênero dos respondentes. A maioria dos participantes da área de gestão de pessoas dessas instituições é formada de mulheres, o que reflete provavelmente o universo dessas áreas no banco Alfa e Beta.

De acordo com a pesquisa realizada pela Febraban (2007), as vinte e oito instituições financeiras participantes empregavam, ao final de 2006, um total de 424.993 colaboradores, sendo $47,7 \%$ desses profissionais, mulheres. A participação feminina cresceu em relação ao ano de 2005, quando era de 46,5\%, seguindo a mesma tendência registrada no País: a presença das mulheres no mercado de trabalho cresce desde 1999 e, de acordo com a pesquisa Nacional de Amostra de Domicílios (PNAD) 2005, as mulheres representavam 44\% da População Economicamente Ativa (PEA), também segundo dados do Instituto Brasileiro de Geografia e Estatística (IBGE, 2008). 
Tabela 6 - Distribuição dos Respondentes por Faixa Etária na Instituição Financeira

\begin{tabular}{|c|c|c|c|}
\hline Instituição & Faixa Etária & Total & Percentuais \\
\hline \multirow{8}{*}{ Alfa } & Até 30 anos & 16 & $25,4 \%$ \\
\hline & 31 a 35 anos & 14 & $22,2 \%$ \\
\hline & 36 a 40 anos & 14 & $22,2 \%$ \\
\hline & 41 a 45 anos & 8 & $12,7 \%$ \\
\hline & 46 a 50 anos & 10 & $15,9 \%$ \\
\hline & Acima de 50 anos & 0 & $0,0 \%$ \\
\hline & Não Respondeu & 1 & $1,6 \%$ \\
\hline & Total & 63 & $100,0 \%$ \\
\hline \multirow{8}{*}{ Beta } & Até 30 anos & 48 & $50,5 \%$ \\
\hline & 31 a 35 anos & 12 & $12,6 \%$ \\
\hline & 36 a 40 anos & 8 & $8,4 \%$ \\
\hline & 41 a 45 anos & 13 & $13,7 \%$ \\
\hline & 46 a 50 anos & 5 & $5,3 \%$ \\
\hline & Acima de 50 anos & 4 & $4,2 \%$ \\
\hline & Não Respondeu & 5 & $5,3 \%$ \\
\hline & Total & 95 & $100,0 \%$ \\
\hline \multicolumn{2}{|c|}{ Total geral } & 158 & - \\
\hline
\end{tabular}

Fonte: Dados da pesquisa

A distribuição dos respondentes por faixa etária é identificada na tabela 6. Nas duas instituições praticamente a metade dos participantes da pesquisa é de jovens (até 35 anos). No banco Beta a faixa até 35 anos representa $63,1 \%$ e no banco Alfa é de 47,6\%, ou seja, os respondentes são mais jovens no banco Beta do que no Alfa.

Segundo dados da Febraban (2007), das vinte e oito instituições financeiras pesquisadas, há uma predominância de profissionais com idade entre 26 e 45 anos, em que se concentram $61,7 \%$ dos colaboradores das instituições. Já a parcela dos profissionais com mais de 46 anos soma 20,7\%. Nos cargos de direção e gerência, prevalecem profissionais com idade entre 36 e 45 anos, que chegam a $45,4 \%$ e $45,1 \%$ do total, respectivamente. Nos cargos de chefia, coordenação ou supervisão, 73,9\% dos colaboradores têm entre 26 e 45 anos, enquanto nos cargos funcionais a média de idade cai, em razão da predominância de pessoas entre 18 e 35 anos, que representam 56,5\% do total.

Tabela 7 - Distribuição dos Respondentes por Nível de Escolaridade na Instituição Financeira

\begin{tabular}{c|l|c|c}
\hline Instituição & \multicolumn{1}{|c|}{ Escolaridade } & Total & Percentuais \\
\hline \multirow{5}{*}{ Alfa } & Até Ensino Médio Completo & 0 & $0,0 \%$ \\
\cline { 2 - 4 } & Superior Incompleto & 5 & $7,9 \%$ \\
\cline { 2 - 4 } & Superior Completo & 26 & $41,3 \%$ \\
\cline { 2 - 4 } & Pós-Graduação Incompleto & 7 & $11,1 \%$ \\
\cline { 2 - 4 } & Pós-Graduação Completo & 25 & $39,7 \%$ \\
\cline { 2 - 4 } & Não Respondeu & 0 & $0,0 \%$ \\
\cline { 2 - 4 } & Total & $\mathbf{6 3}$ & $\mathbf{1 0 0 , 0 \%}$ \\
\hline \multirow{5}{*}{ Beta } & Até Ensino Médio Completo & 3 & $3,2 \%$ \\
\cline { 2 - 4 } & Superior Incompleto & 21 & $22,1 \%$ \\
\hline
\end{tabular}




\begin{tabular}{c|l|c|c}
\hline & Superior Completo & 42 & $44,2 \%$ \\
\cline { 2 - 4 } & Pós-Graduação Incompleto & 9 & $9,5 \%$ \\
\cline { 2 - 4 } & Pós-Graduação Completo & 16 & $16,8 \%$ \\
\cline { 2 - 4 } & Não Respondeu & 4 & $4,2 \%$ \\
\cline { 2 - 4 } & Total & $\mathbf{9 5}$ & $\mathbf{1 0 0 , 0 \%}$ \\
\hline & Total geral & $\mathbf{1 5 8}$ & - \\
\hline
\end{tabular}

Fonte: Dados da pesquisa

A tabela 7 demonstra a distribuição da escolaridade dos respondentes da pesquisa nas Instituições Financeiras, onde a maioria possui superior completo ou pós-graduado (incompleto ou completo). No banco Alfa representa 92,1\% e no banco Beta 70,5\%. Este alto nível de escolaridade pode ser explicado por políticas de gestão de pessoas de incentivo ao estudo com o auxílio e pagamentos de mensalidades de graduações ou pós-graduações e a exigência crescente da qualificação desses profissionais.

A Febraban (2007), em sua pesquisa com as vinte e oito instituições financeiras, aponta que a média de escolaridade dos colaboradores dos bancos também supera à nacional. De acordo com as instituições, chega a $27,4 \%$ o número de funcionários que concluíram o ensino médio ou profissional, e 18,7\% estão cursando o terceiro grau, enquanto os com graduação completa totalizam $40,8 \%$, e os pós-graduados, $10,9 \%$.

No Brasil, o percentual de pessoas com mais de 11 anos de instrução era de 27,2\% no último levantamento populacional do IBGE (2008), a PNAD 2005. Entre as mulheres que trabalhavam nos bancos no final de $2006,9,5 \%$ possuíam pós-graduação, enquanto entre os homens o indicador chega a $12,1 \%$. Já a parcela de graduados é maior entre elas do que entre eles: $42,9 \%$ e $38,8 \%$.

Tabela 8 - Distribuição dos Respondentes por Número de Dependentes na Instituição Financeira

\begin{tabular}{c|l|c|c}
\hline Instituição & \multicolumn{1}{|c|}{ Dependentes } & Total & Percentuais \\
\hline \multirow{4}{*}{ Alfa } & Nenhum & 26 & $41,3 \%$ \\
\cline { 2 - 4 } & Um & 11 & $17,5 \%$ \\
\cline { 2 - 4 } & Dois & 18 & $28,6 \%$ \\
\cline { 2 - 4 } & Três & 4 & $6,3 \%$ \\
\cline { 2 - 4 } & Quatro ou mais & 3 & $4,8 \%$ \\
\cline { 2 - 4 } & Não Respondeu & 1 & $1,6 \%$ \\
\cline { 2 - 4 } & Total & $\mathbf{6 3}$ & $\mathbf{1 0 0 , 0 \%}$ \\
\hline \multirow{5}{*}{ Beta } & Nenhum & 47 & $49,5 \%$ \\
\cline { 2 - 4 } & Um & 24 & $25,3 \%$ \\
\cline { 2 - 4 } & Dois & 5 & $9,5 \%$ \\
\cline { 2 - 4 } & Três & $6,3 \%$ \\
\cline { 2 - 4 } & Quatro ou mais & $\mathbf{9 5}$ & $4,2 \%$ \\
\cline { 2 - 4 } & Não Respondeu & $\mathbf{1 5 8}$ & - \\
\cline { 2 - 4 } & Total & $\mathbf{1 0 0 , 0 \%}$ \\
\hline
\end{tabular}


Identifica-se na tabela 8 a distribuição dos participantes da pesquisa por número de dependentes. Quase a metade dos respondentes nas duas instituições financeiras não possui dependentes. Isto pode ser explicado pela redução das famílias no Brasil, como apontado pelo IBGE (2008).

Nesse sentido, a Febraban (2007) aponta que dentre as instituições pesquisadas, 32\% afirmaram possuir projetos para contribuir com o desenvolvimento de filhos de funcionários, que se refere à competência técnica como a aspectos psicossociais, envolvendo atividades de esporte e arte. Já $24 \%$ declararam estender essas atividades às crianças de comunidades e apoiar iniciativas do poder público que tenham esse mesmo sentido, 12\% relataram que apóiam o ingresso de jovens no mercado por intermédio do programa Primeiro Emprego, do governo federal, de acordo com a Lei $\mathrm{n}^{\circ} 10.748$, de 2003.

Sintetizando os dados demográficos, no banco Alfa e Beta a maior parcela dos respondentes é de técnicos, analistas ou auxiliares; são maioria mulheres, jovens até 35 anos, possuem superior completo ou são pós-graduados e não possuem dependentes.

$\mathrm{Na}$ seqüência estão apresentadas as análises descritivas da pesquisa de campo.

\subsection{Análise Descritiva}

A estatística descritiva tem como objetivo sumarizar e descrever os aspectos relevantes num conjunto de dados, visando facilitar o entendimento do comportamento amostral por meio de medidas-resumo, gráficos e estabelecimento de relações entre variáveis (MAGALHÃES; LIMA, 2005).

A análise descritiva apresentada a seguir envolve as informações relacionadas às variáveis/aspectos: liderança, gestão de pessoas e aspectos: organizacionais, biológicos, psicológicos e sociais.

Todas as questões dessas variáveis foram mensuradas numa escala Likert de cinco pontos. A escala Likert identifica uma série de proposições, das quais os respondentes devem selecionar uma. No aspecto liderança a escala era: sem importância (1), pouca importância (2), indiferente/sem opinião (3), importante (4), total importância (5). No aspecto gestão de pessoas a escala era: discordo totalmente (1), discordo parcialmente (2), indiferente/sem opinião (3), concordo parcialmente (4), concordo totalmente (5). Nos aspectos organizacionais, biológicos, psicológicos e sociais a escala era: totalmente insatisfeito (1), parcialmente insatisfeito (2), indiferente/sem opinião (3), parcialmente satisfeito (4), 
totalmente satisfeito (5). Foi considerado que existia simetria entre os níveis/graus que constavam nas escalas de respostas. Esta observação constava no instrumento de pesquisa.

A seguir apresenta-se a tabela 9 com a proporção dos funcionários participantes da pesquisa que responderam as alternativas 4 ou 5 (importância, concordância e satisfação) da escala Likert em cada questão, geral da questão e aspecto nas duas Instituições Financeiras.

Tabela 9 - Proporção dos Respondentes que afirmaram importante ou total importância em cada questão - Aspecto Liderança por Instituição Financeira

\begin{tabular}{c|c|c|c|c}
\hline \multicolumn{1}{c}{ Aspecto } & \multicolumn{1}{c}{ Questão } & \multicolumn{1}{c}{ Alfa } & \multicolumn{1}{c}{ Beta } & Geral - Questão \\
\hline \multirow{5}{*}{ Liderança } & Q2 & $95,24 \%$ & $80,22 \%$ & $86,36 \%$ \\
\cline { 2 - 5 } & Q3 & $95,16 \%$ & $82,61 \%$ & $87,66 \%$ \\
\cline { 2 - 5 } & Q4 & $87,30 \%$ & $60,87 \%$ & $71,61 \%$ \\
\cline { 2 - 5 } & Q5 & $88,71 \%$ & $64,44 \%$ & $74,34 \%$ \\
\cline { 2 - 5 } & Q6 & $96,83 \%$ & $80,22 \%$ & $87,01 \%$ \\
\cline { 2 - 5 } & Q7 & $92,06 \%$ & $54,95 \%$ & $70,13 \%$ \\
\cline { 2 - 5 } & Q8 & $82,54 \%$ & $52,22 \%$ & $64,71 \%$ \\
\cline { 2 - 5 } & Q9 & $79,37 \%$ & $50,54 \%$ & $62,18 \%$ \\
\cline { 2 - 5 } & Q10 & $83,87 \%$ & $65,22 \%$ & $72,73 \%$ \\
\cline { 2 - 5 } & Q11 & $93,44 \%$ & $84,95 \%$ & $88,31 \%$ \\
\cline { 2 - 5 } & Q12 & $91,80 \%$ & $82,80 \%$ & $86,36 \%$ \\
\cline { 2 - 5 } & Q13 & $77,78 \%$ & $60,44 \%$ & $67,53 \%$ \\
\cline { 2 - 5 } & Q14 & $95,24 \%$ & $73,63 \%$ & $82,47 \%$ \\
\cline { 2 - 5 } & Q15 & $93,65 \%$ & $78,49 \%$ & $84,62 \%$ \\
\hline Geral - Liderança & & $\mathbf{8 9 , 4 9 \%}$ & $\mathbf{6 9 , 4 5 \%}$ & $\mathbf{7 7 , 5 7 \%}$ \\
\hline
\end{tabular}

Fonte: Dados da pesquisa

Na questão dois do instrumento de pesquisa, que trata o foco absoluto em resultados, de acordo com os respondentes, o banco Alfa é mais orientado para esse objetivo do que o banco Beta, sendo que obteve o terceiro maior resultado geral no aspecto liderança nesse item. Reforça esse entendimento a questão seis que aborda a liderança orientada para resultados, onde foi encontrada a maior proporção de respostas do banco Alfa.

A questão onze afirma que os líderes devem agir para a produção de resultados Obteve-se a maior proporção no banco Beta e a maior média geral das duas instituições financeiras investigadas.

Em relação à questão quatorze, que trata dos líderes motivados com a obtenção de resultados positivos, no banco Alfa foi encontrada a segunda maior proporção nesse aspecto.

As atividades e oportunidades de desenvolvimento ajudam a produzir resultados, particularmente não perde oportunidades de desenvolvimento. $O$ banco investe nisso. Busca-se aproveitar as capacidades dos funcionários, isso se dá por meio do programa de carreira e capacitação, que no Brasil é tão novo quanto o Banco.

(Entrevistado 4 - Banco Beta). 
Esse relato do entrevistado 4 do banco Beta destaca as iniciativas para a obtenção de resultados por meio do desenvolvimento e capacitação dos colaboradores, relacionando-se com os planos de carreira e remuneração.

Tabela 10 - Proporção dos Respondentes que afirmaram concordância parcial ou total em cada questão Aspecto Gestão de Pessoas por Instituição Financeira

\begin{tabular}{c|c|c|c|c}
\hline \multicolumn{1}{c}{ Aspecto } & Questão & Alfa & \multicolumn{1}{c}{ Beta } & Geral - Questão \\
\hline \multirow{5}{*}{ Gestão de Pessoas } & Q16 & $100,00 \%$ & $89,25 \%$ & $93,59 \%$ \\
\cline { 2 - 5 } & Q17 & $90,48 \%$ & $75,27 \%$ & $81,41 \%$ \\
\cline { 2 - 5 } & Q18 & $82,26 \%$ & $36,96 \%$ & $55,19 \%$ \\
\cline { 2 - 5 } & Q19 & $84,13 \%$ & $51,61 \%$ & $64,74 \%$ \\
\cline { 2 - 5 } & Q20 & $66,67 \%$ & $49,46 \%$ & $56,41 \%$ \\
\cline { 2 - 5 } & Q21 & $77,78 \%$ & $39,56 \%$ & $55,19 \%$ \\
\cline { 2 - 5 } & Q22 & $80,95 \%$ & $47,83 \%$ & $61,29 \%$ \\
\cline { 2 - 5 } & Q23 & $53,23 \%$ & $32,97 \%$ & $41,18 \%$ \\
\cline { 2 - 5 } & Q24 & $77,78 \%$ & $41,76 \%$ & $56,49 \%$ \\
\cline { 2 - 5 } & Q25 & $84,13 \%$ & $35,48 \%$ & $55,13 \%$ \\
\cline { 2 - 5 } & Q26 & $76,19 \%$ & $52,69 \%$ & $62,18 \%$ \\
\cline { 2 - 5 } & Q27 & $80,65 \%$ & $48,91 \%$ & $61,69 \%$ \\
\cline { 2 - 5 } & Q28 & $80,95 \%$ & $50,54 \%$ & $62,82 \%$ \\
\hline Geral - Gestão de Pessoas & & $\mathbf{7 9 , 6 6 \%}$ & $\mathbf{5 0 , 2 5 \%}$ & $\mathbf{6 2 , 1 5 \%}$ \\
\hline
\end{tabular}

Fonte: Dados da pesquisa

Em relação à questão dezesseis que trata do cumprimento individual das expectativas do banco, na instituição Alfa foi encontrada a maior proporção nesse aspecto com 100\%, seguida do Beta com $89,25 \%$. No geral da questão obteve-se a maior média com 93,59\%.

Essa questão aborda a forma de organização do trabalho, sendo por equipe na opinião da maioria dos respondentes do banco Alfa e Beta, com a segunda proporção geral encontrada no aspecto gestão de pessoas.

Nesse sentido, o relato do entrevistado 1 do banco Alfa é relevante, pois explica como é o processo decisorial e o sistema de remuneração nesta instituição:

As decisões no meu setor são totalmente compartilhadas. Repasso os problemas para a equipe e concedo prazo para que reflitam e apresentem soluções. As alternativas são analisadas por mim e pela equipe e escolhe-se a melhor.

Atualmente o salário é fixo e baseado no plano de cargos e salários da empresa e, existe a remuneração variável que depende exclusivamente do desempenho individual. Para o futuro próximo não haverá vínculos entre remuneração variável $e$ desempenho individual, pois estão ocorrendo mudanças no plano de cargos $e$ salários e no programa de remuneração variável. (Entrevistado 1 - Banco Alfa). 
Tabela 11 - Proporção dos Respondentes que afirmaram parcialmente ou totalmente satisfeitos em cada questão - Aspectos organizacionais, biológicos, psicológicos e sociais por Instituição Financeira

\begin{tabular}{|c|c|c|c|c|}
\hline Aspecto & Questão & Alfa & Beta & Geral - Questão \\
\hline \multirow{5}{*}{ Aspectos Organizacionais } & Q29 & $87,30 \%$ & $59,14 \%$ & $70,51 \%$ \\
\hline & Q30 & $90,48 \%$ & $49,46 \%$ & $66,03 \%$ \\
\hline & Q31 & $76,19 \%$ & $53,76 \%$ & $62,82 \%$ \\
\hline & Q32 & $66,67 \%$ & $44,09 \%$ & $53,21 \%$ \\
\hline & Q33 & $74,60 \%$ & $40,22 \%$ & $54,19 \%$ \\
\hline \multicolumn{2}{|c|}{ Geral - Aspectos Organizacionais } & $\mathbf{7 9 , 0 5 \%}$ & $49,35 \%$ & $61,36 \%$ \\
\hline \multirow{5}{*}{ Aspectos Biológicos } & Q34 & $87,30 \%$ & $47,83 \%$ & $63,87 \%$ \\
\hline & Q35 & $100,00 \%$ & $88,04 \%$ & $92,86 \%$ \\
\hline & Q36 & $87,30 \%$ & $72,83 \%$ & $78,71 \%$ \\
\hline & Q37 & $87,10 \%$ & $71,74 \%$ & $77,92 \%$ \\
\hline & Q38 & $88,52 \%$ & $64,13 \%$ & $73,86 \%$ \\
\hline Geral - Aspectos Biológicos & & $90,03 \%$ & $68,91 \%$ & $77,43 \%$ \\
\hline \multirow{5}{*}{ Aspectos Psicológicos } & Q39 & $76,19 \%$ & $62,37 \%$ & $67,95 \%$ \\
\hline & Q40 & $79,37 \%$ & $60,22 \%$ & $67,95 \%$ \\
\hline & Q41 & $80,95 \%$ & $50,54 \%$ & $62,82 \%$ \\
\hline & Q42 & $74,60 \%$ & $43,96 \%$ & $56,49 \%$ \\
\hline & Q43 & $80,33 \%$ & $57,30 \%$ & $66,67 \%$ \\
\hline \multicolumn{2}{|c|}{ Geral - Aspectos Psicológicos } & $\mathbf{7 8 , 2 7 \%}$ & $54,90 \%$ & $64,38 \%$ \\
\hline \multirow{5}{*}{ Aspectos Sociais } & Q44 & $98,41 \%$ & $91,30 \%$ & $94,19 \%$ \\
\hline & $\mathrm{Q} 45$ & $65,08 \%$ & $50,00 \%$ & $56,13 \%$ \\
\hline & Q46 & $58,06 \%$ & $31,11 \%$ & $42,11 \%$ \\
\hline & Q47 & $55,56 \%$ & $26,09 \%$ & $38,06 \%$ \\
\hline & Q48 & $87,30 \%$ & $68,82 \%$ & $76,28 \%$ \\
\hline Geral - Aspectos Sociais & & $72,93 \%$ & $53,59 \%$ & $61,45 \%$ \\
\hline
\end{tabular}

Fonte: Dados da pesquisa

A questão vinte e nove trata da imagem do banco junto aos bancários. Obteve-se a maior média geral no aspecto organizacional. As oportunidades de treinamento foram verificadas na questão trinta, onde se obteve a maior proporção do banco Alfa nesse aspecto, com $90,48 \%$.

Nesse sentido, o entrevistado 1 corroborou com os resultados da pesquisa quantitativa, pois afirmou que:

Existe o Programa Bolsa Educacional - em que o banco paga 50\% da graduação elou curso de pós-graduação para cada colaborador, ou seja, cada colaborador recebe $50 \%$ do valor da mensalidade para pagar sua faculdade, sendo limitado para uma graduação e uma pós para cada colaborador;

Os cursos de línguas são bancados de 50 a 100\%, dependendo do caso, somente para os altos executivos, desde que necessitem. (Entrevistado 1 - Banco Alfa).

Por outro lado, o entrevistado 2 da instituição Alfa, insatisfeito com o programa de incentivo a qualificação fez a seguinte afirmação:

Os apoios financeiros para qualificação são insuficientes, contemplam apenas alguns funcionários. Não recebi valor algum para minha pós-graduação. (Entrevistado 2 - Banco Alfa). 
Segundo a Febraban (2007), para o desenvolvimento profissional, 64\% dos bancos pesquisados informaram ter oferecido a média de 95 horas de treinamento por funcionário, somando investimentos de R \$ 670,3 milhões no ano de 2006 entre os vinte e oito bancos participantes.

O destaque do aspecto biológico foi a questão trinta e cinco, atendimento do convênio médico, com $100 \%$ de satisfação no banco Alfa e 88,04\% no banco Beta, resultando na maior proporção geral nesse aspecto com $92,86 \%$. Nos quatro aspectos analisados, foi obtida a maior proporção geral na instituição Alfa, com 90,03\% e Beta com 68,91\%.

Nesse sentido, os entrevistados das duas instituições destacaram sua satisfação nesse aspecto:

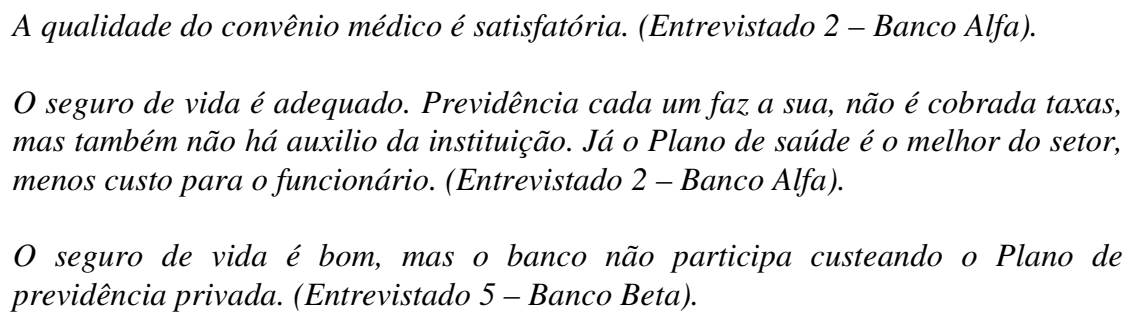

De acordo com a pesquisa da Febraban (2007), os bancos adotaram medidas relacionadas à manutenção da saúde e segurança dos funcionários. Em 64\% dos bancos pesquisados são mantidos planos e estipuladas metas para alcançar os padrões máximos de excelência nesses aspectos. Outra iniciativa inclui pesquisas para verificar o grau de satisfação dos funcionários com relação às práticas adotadas.

No aspecto psicológico, a questão trinta e nove aborda a forma de avaliação do desempenho individual do trabalho e, no banco Beta foi encontrada a proporção 62,37\%.

Os relatos dos entrevistados quatro e cinco do banco Beta explicam o funcionamento com satisfação parcial do sistema de avaliação de desempenho na instituição:

\footnotetext{
A ferramenta é boa, mas as pessoas ainda estão aprendendo a lidar com ela com mais seriedade. (Entrevistado 4 - Banco Beta).

Há 2 maneiras, o gestor dá feedback no dia-a-dia e através da avaliação de desempenho. Acredita e pratica com seu grupo de trabalho a primeira, acha que é melhor, mais pontual. A mais percebida é a segunda, pois a maioria dos gestores espera a avaliação de desempenho (2X ao ano) para dar feedback. (Entrevistado 5 - Banco Beta).
}

Na questão quarenta e um - oportunidade de carreira, foi encontrada a proporção de $80,95 \%$, sendo a maior nesse aspecto das instituições analisadas; consideram-se as possibilidades de ascensão na empresa e plano estruturado de carreira. 
Dessa forma, é relevante o entendimento do entrevistado três, sobre as oportunidades de carreira na instituição Beta:

Tem muita oportunidade, mas a oportunidade é criada pela própria pessoa, estou a 5 anos na empresa e já atuei em 6 posições diferentes. Pessoalmente, minha primeira preocupação quando assumo uma nova posição é preparar um sucessor, para poder aproveitar novas oportunidades quando estas surgem. Acredito que os membros da organização acham que não tem oportunidades, não percebem isso na maioria das pessoas com as quais se relacionam. (Entrevistado 03 - Banco Beta).

No aspecto social, a questão destaque foi a quarenta e quatro, que trata a qualidade dos convênios de saúde, onde se obteve a maior proporção de satisfação com 98,41\% no banco Alfa e $91,30 \%$ no Beta. Por outro lado, foram os resultados gerais mais baixos dos quatro aspectos analisados, onde a proporção de satisfação na instituição Alfa foi 72,93\% e Beta de $53,59 \%$.

Destacam-se as iniciativas das instituições analisadas, visando a melhoria das condições de trabalho dos funcionários nos aspectos ergonômicos, identificados nos relatos dos entrevistados:

Existe toda uma preocupação com ergonomia e, mais recentemente com o problema de transtorno mental, para o qual os gestores estão sendo treinados para identificar esses transtornos nos seus colaboradores e encaminhá-los para os referidos tratamentos. (Entrevistado 01 - Banco Alfa)

Acha que são muito bons os aspectos de prevenção da LER/DORT, a cada 6 meses um profissional visita a empresa para verificar se os equipamentos estão posicionados corretamente, avaliar a postura. Também há ginástica laboral 1 vez por semana. (Entrevistado 3 - Banco Beta).

A área de saúde está sempre em inovação, atualmente vem sendo percebida como investimento. A organização começa a dar valor, os funcionários estão solicitando práticas no sentido de QVT. Sente-se muito bem, o trabalho não esgota fisicamente. Todos os equipamentos estão adequados, busca-se atender a legislação. (Entrevistado 4 - Banco Beta).

Foram feitas duas blitz de ergonomia neste ano, há preocupação com o posicionamento correto dos equipamentos. Há ginástica laboral 2 vezes por semana. Nas regiões de maior concentração de funcionários que são cobertas, acredita que os funcionários estão satisfeitos, nas regiões mais remotas dos pontos de venda não há cobertura.

Sinto-me normalmente mais cansada, depende da exigência do trabalho do dia, de fatores da vida pessoal, do trânsito. Na verdade isso depende de diversos fatores não só do trabalho. As pessoas sentem-se cansadas, há a questão do stress devido a fusão, pesa muito o mental e o emocional, nesse setor isso é muito forte. (Entrevistado 5 - Banco Beta).

Segundo a pesquisa realizada em vinte e oito instituições financeiras, em $56 \%$ dos bancos verificam-se exercícios físicos no horário de trabalho e $20 \%$ mantêm políticas que 
buscam criar condições para que os colaboradores possam melhor equilibrar a vida profissional e pessoal. Em 36\% são promovidos programas de prevenção e tratamentos de problemas relacionados a drogas e álcool para os funcionários, enquanto $28 \%$ têm iniciativas específicas para portadores de HIV e 24\% relacionadas à saúde da mulher no ano de 2006 (FEBRABAN, 2007).

Tabela 12 - Proporções mais baixas nas variáveis X questões e instituições financeiras

\begin{tabular}{l|c|c}
\hline \multicolumn{1}{c|}{ Variável } & $\begin{array}{c}\text { Alfa } \\
\text { Questões }\end{array}$ & $\begin{array}{c}\text { Beta } \\
\text { Questões }\end{array}$ \\
\hline Liderança & 13 & 7,8 e 9 \\
\hline Gestão Estratégica Pessoas & 20 e 23 & $\begin{array}{c}18,20,21,22,23,24 \\
\text { e } 25\end{array}$ \\
\hline Aspectos Organizacionais & 31,32 e 33 & 30,32 e 33 \\
\hline Aspectos Biológicos & $*$ & 34 \\
\hline Aspectos Psicológicos & 39 e 42 & 42 \\
\hline Aspectos Sociais & 46 e 47 & 46 e $47 * *$ \\
\hline
\end{tabular}

Fonte: Dados da pesquisa

* Os resultados encontrados nesse grupo foram todos superiores à média.

** Resultado inferior de todos os grupos.

A tabela 12 identifica as questões/variáveis de pesquisa com as proporções mais baixas de acordo com os respondentes das instituições financeiras investigadas.

No Banco Alfa os resultados inferiores foram às questões vinte e três, que tratam da forma pela qual o banco determina os salários pelo desempenho individual, e as questões quarenta e seis e quarenta e sete, que abordam a qualidade da previdência privada e o apoio financeiro para qualificação (pós-graduação, graduação), demonstrando uma satisfação entre $53 \%$ a 58\% nesses três itens, como já analisadas nas tabelas 10 e 11.

Por outro lado, de acordo com os dados da pesquisa de 2006 da Febraban (2007), em relação à remuneração e benefícios, as instituições financeiras pesquisadas visam fornecer bons salários e conceder benefícios aos colaboradores; é importante para mantê-los motivados e proporcionar, paralelamente, melhorias nas suas condições de vida. $60 \%$ declararam manter programas de remuneração variável para os seus funcionários, com abrangência que varia de instituição para instituição. Programas de stock options são oferecidos por $12 \%$ das instituições, sendo que em 33,3\% dos casos ele é acessível a todos os níveis hierárquicos.

Entre os benefícios, $28 \%$ oferecem auxílio-educação para filhos de funcionários; $40 \%$ garantem financiamento diferenciado para a casa própria; todos os bancos colocam à disposição creches no próprio ambiente de trabalho ou em rede conveniada, ou pagam 
benefício que permite a livre escolha dos colaboradores; $88 \%$ oferecem planos de saúde familiar; e $68 \%$ garantem plano de previdência complementar a todos os seus funcionários.

Para avaliar a satisfação com relação às políticas de salários e benefícios, $56 \%$ dos bancos incluem itens relacionados a esses temas nos levantamentos que realizam entre os colaboradores.

Os respondentes da instituição Beta apontaram os resultados mais baixos nas questões sete, oito e nove - envolvimento em atividades e oportunidades de desenvolvimento que ajudam a produzir melhores resultados, utilização total das capacidades dos funcionários nas oportunidades de qualificação e da inovação em todas as áreas sob a sua influência, onde o grau de importância ficou entre 50, 54\% e 54,95\%.

Em relação à gestão estratégica de pessoas no banco Beta, apurou-se resultado inferior a 50\% nas questões dezoito, vinte a vinte e cinco. A concordância ficou entre $32,97 \%$ na questão vinte e três, que trata como os salários são determinados pelo desempenho individual, até $49,46 \%$ na questão vinte. Isso pode ser decorrente da falta de políticas consolidadas de gestão de pessoas na instituição e/ou de uma fase de transição atual de cultura organizacional.

Nos aspectos organizacionais, as questões inferiores a 50\% foram a trinta, trinta e dois e trinta e três, com 49,46\%, 44,09\% e 40,22\% respectivamente, as quais envolvem fatores como oportunidades de treinamento, oportunidades de participar de decisões e nível de comunicação interna. No aspecto biológico a questão trinta e quatro, que aborda o controle dos riscos relacionados a DORT, foi a única no grupo com resultado inferior a 50\%, ou seja, obteve 47,83\%. A questão quarenta e dois, que investigou a satisfação com a remuneração, atingiu uma proporção de 43,96\%.

No banco Beta, os aspectos sociais, através das questões quarenta e seis e quarenta e sete, obtiveram os resultados mais baixos de toda pesquisa. A qualidade da previdência privada e o apoio financeiro para qualificação (pós-graduação, graduação) foram os destaques negativos, com uma proporção de $31,11 \%$ e 26,09\% respectivamente. Isso pode ser decorrente da falta de estruturação desses dois programas na instituição Beta. 
5.5 Matriz de Correlação de SPEARMAN

De acordo com o dicionário Aurélio, correlação significa "relação mútua entre dois termos, qualidade de correlativo, correspondência. Correlacionar, significa estabelecer relação ou correlação entre; ter correlação."

A matriz de correlação de Spearman auxilia na observação da inter-relação entre as respostas dos bancários para as questões e variáveis. O coeficiente de correlação de Sperman é uma medida de correlação não-paramétrica, ou seja, demonstra a distribuição de frequiências das variáveis (neste estudo o Likert).

O coeficiente de Spearman é representado pela letra " $r$ "e assume apenas valores entre 1 e 1, sendo que:

- $\mathrm{r}=1$, significa uma associação perfeita positiva entre as duas variáveis (as duas variáveis aumentam ou diminuem ao mesmo tempo);

- $\mathrm{r}=-1$, significa uma associação negativa perfeita entre as duas variáveis (uma variável aumenta e a outra diminui);

- $\mathrm{r}=0$, significa que as duas variáveis não estão associadas.

Quanto mais próximo estiver de 1 ou -1, mais forte é a associação linear entre as duas variáveis. 
Tabela 13 - Matriz de Correlação entre as questões de pesquisa

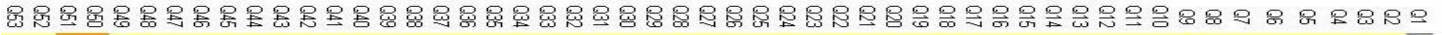

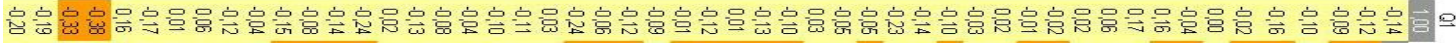

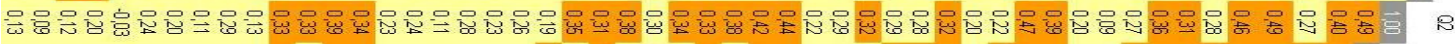
읕음울을 응

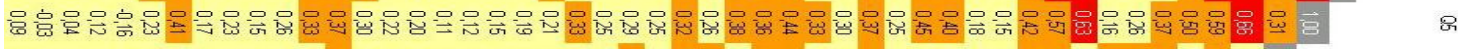

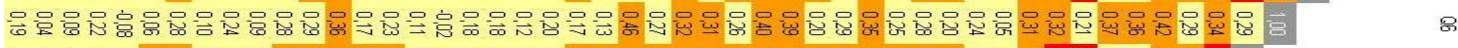

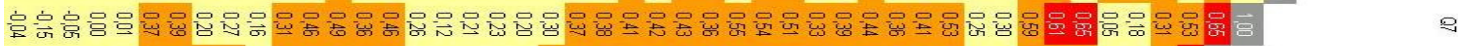

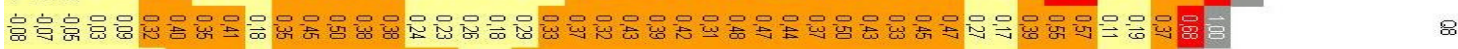

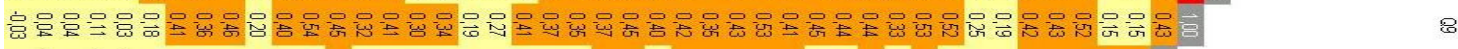

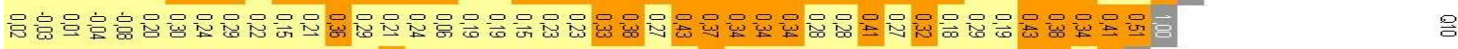

음

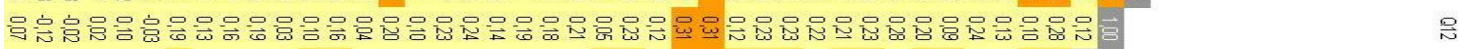

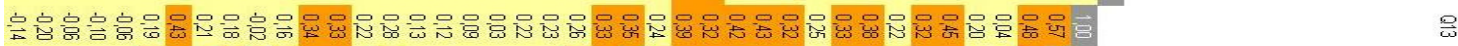

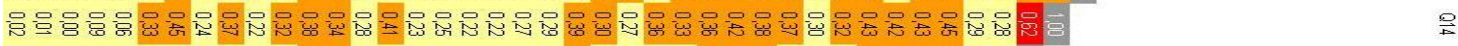

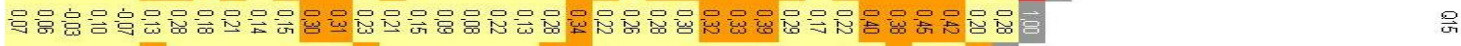

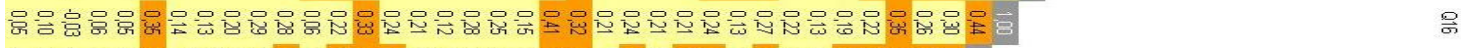

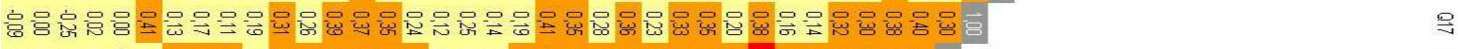

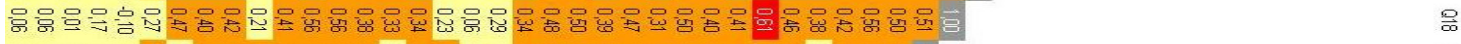

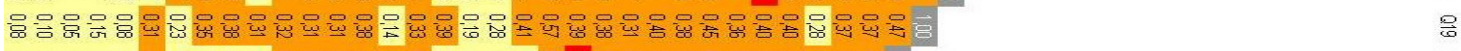

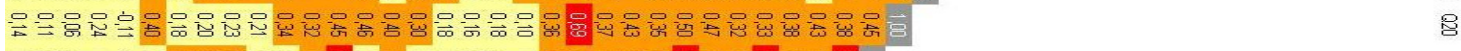

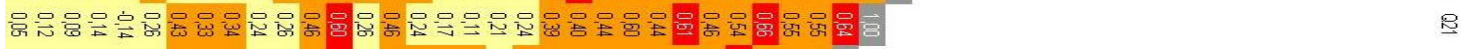

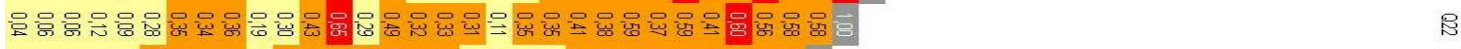

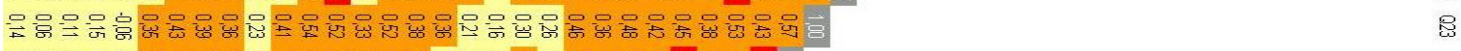

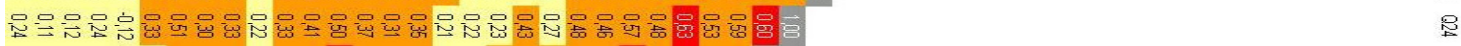

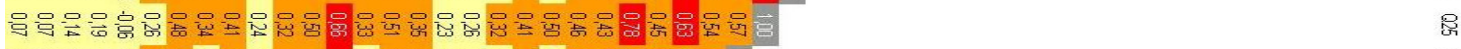

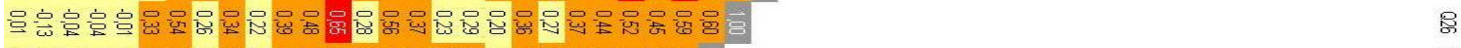

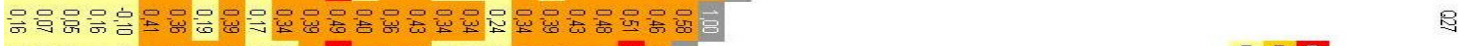

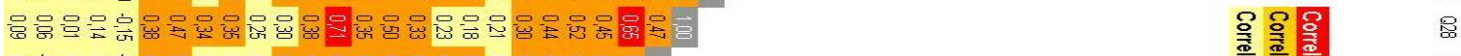

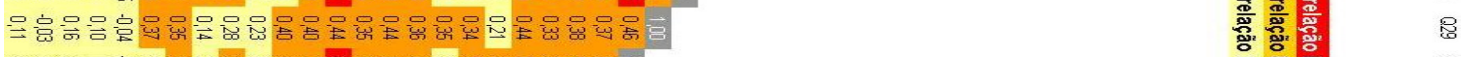

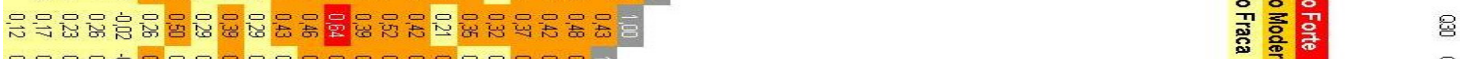

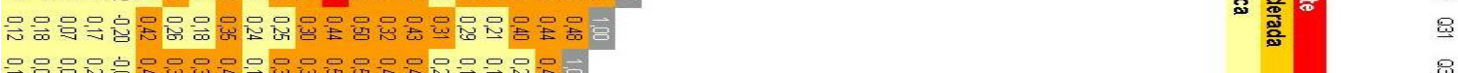

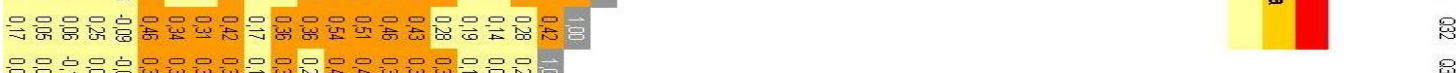

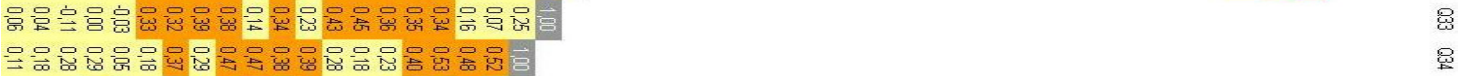

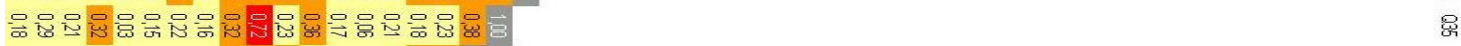

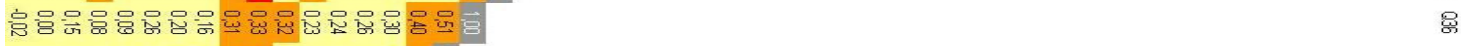

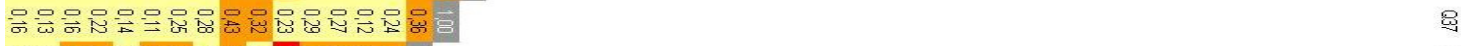

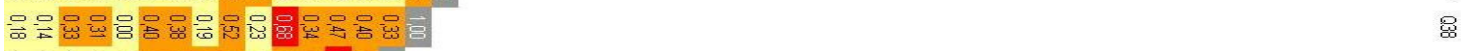

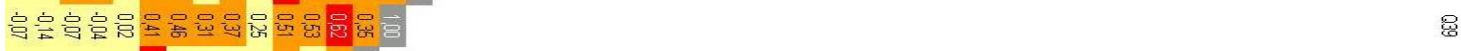

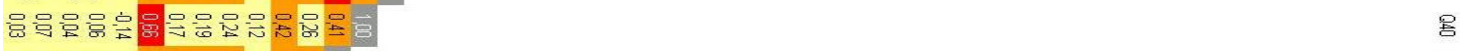

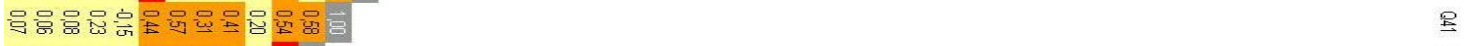

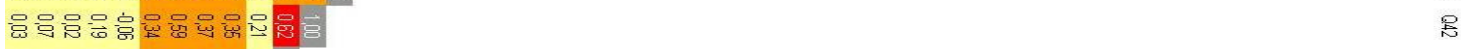

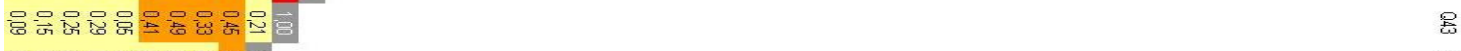

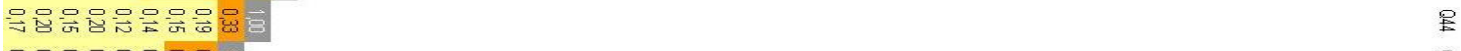

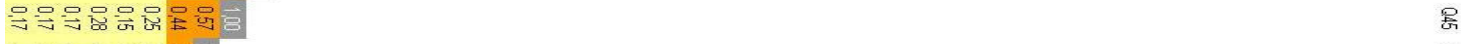

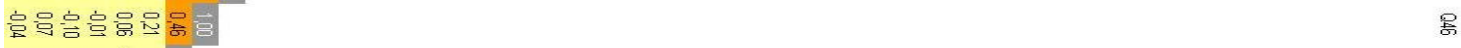

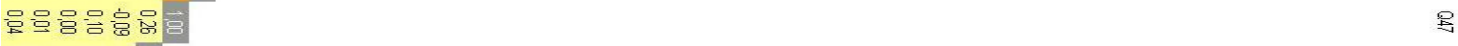

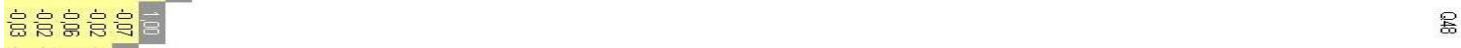

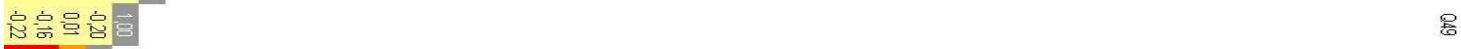

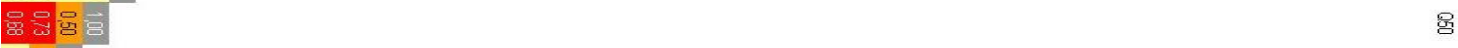

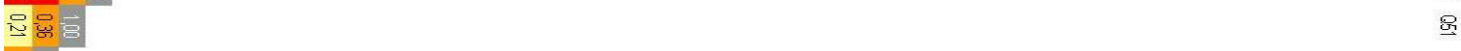

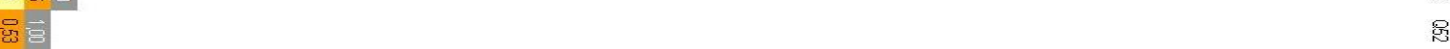


De acordo com a tabela 13 da matriz de correlação de Spearman, observa-se que existe associação forte (em vermelho) entre aquelas questões que apresentam um nível inferior de importância/concordância ou satisfação dos funcionários respondentes.

5.6 Mapa de Correlação de PEARSON das variáveis de QVT com liderança e GEP

O coeficiente de correlação de Pearson é normalmente representado pela letra "r" e a sua fórmula de cálculo é:

$$
r=\frac{\sum\left(x_{i}-\bar{x}\right)\left(y_{i}-\bar{y}\right)}{\sqrt{\left(\sum\left(x_{i}-\bar{x}\right)^{2}\right)\left(\sum\left(y_{i}-\bar{y}\right)^{2}\right)}}
$$

Tabela 14 - Matriz de correlação entre as variáveis* Aspectos Biológicos Aspectos Organizacionais Aspectos Psicológicos Aspectos Sociais Gestão de Pessoas Liderança

\begin{tabular}{ccccccc} 
& Aspectos Biológicos & Aspectos Organizacionals & Aspectos Psicológicos & Aspectos Sociais Gestão de Pessoas Liderança \\
Aspectos Biológicos & 1,00 & 0,51 & 0,48 & 0,53 & 0,47 & 0,37 \\
Aspectos Organizacionais & 0,51 & 1,00 & 0,72 & 0,58 & 0,78 & 0,59 \\
Aspectos Psicológicos & 0,48 & 0,72 & 1,00 & 0,65 & 0,73 & 0,59 \\
Aspectos Sociais & 0,53 & 0,58 & 0,65 & 1,00 & 0,62 & 0,48 \\
Gestão de Pessoas & 0,47 & 0,78 & 0,73 & 0,62 & 1,00 & 0,65 \\
Liderança & 0,37 & 0,59 & 0,59 & 0,48 & 0,65 & 1,00 \\
& \multicolumn{7}{c}{ Correlação Forte } \\
& * Correlação Moderada & & \\
& Correlação Fraca &
\end{tabular}

Fonte: Dados da pesquisa

Os resultados demonstrados na tabela 13 e 14 apontam que a determinação do que o funcionário deve fazer para melhorar os resultados finais (q5) tem uma correlação com a comunicação interna das metas e objetivos (q4) na ordem de 0,69. O envolvimento em atividades e oportunidades de desenvolvimento que ajudam a produzir melhores resultados (q7) tem uma correlação com a comunicação interna das metas e objetivos (q4) na ordem de 0,70. O envolvimento em atividades e oportunidades de desenvolvimento que ajudam a produzir melhores resultados (q7) tem uma correlação com a determinação do que o funcionário deve fazer para melhorar os resultados finais (q5) na ordem de 0,66 e assim por diante.

As maiores correlações estão na satisfação com as oportunidades de treinamento e desenvolvimento profissional, com o oferecimento de oportunidades constantes de qualificação para os funcionários em 0,78. A satisfação com as oportunidades de carreira tem 
uma correlação com sete questões dos grupos de variáveis "gestão estratégica de pessoas, aspectos organizacionais e psicológicos".

A tabela 14 demonstra o mapa de correlação de Pearson dos aspectos de QVT, gestão de pessoas e liderança.

Nos aspectos organizacionais verifica-se uma correlação com os aspectos psicológicos e gestão de pessoas, este último com a maior correlação entre todos na ordem de 0,78 . Isso pode ser decorrente das políticas existentes de gestão de pessoas dessas instituições financeiras analisadas na percepção dos respondentes.

Os aspectos psicológicos apresentam uma correlação com os organizacionais, sociais e gestão de pessoas, principalmente na questão relativa à satisfação com as oportunidades de carreira e participação.

Nesse sentido, de acordo com os dados da pesquisa da Febraban (2007), em relação ao envolvimento dos funcionários na gestão dos negócios, o mesmo também é fundamental para mantê-los motivados e focados de forma a aperfeiçoar cada vez mais as atividades desenvolvidas pelas instituições. Em 92\% dos bancos, é prática colocar à disposição dos colaboradores informações relevantes e estimulá-los a analisá-las dentro do contexto, de forma a incentivar a sua contribuição na formulação de planos e estratégias - e reconhecê-los por isso. Além disso, $72 \%$ dos bancos relataram que os integrantes de comissões de trabalhadores, como a Comissão Interna de Prevenção de Acidentes (Cipa), Comissão de Conciliação Prévia (CCP), de participação nos lucros e resultado etc., são eleitos pelos trabalhadores sem interferência da instituição.

A gestão de pessoas possui correlação forte com os aspectos organizacionais, psicológicos, sociais e liderança. Finalmente, a liderança tem correlação forte com gestão de pessoas na ordem de 0,65 .

No próximo item estão apresentadas as análises fatoriais da pesquisa de campo.

\subsection{Análise Fatorial}

A técnica multivariada de análise fatorial é a de que dimensões latentes podem ser usadas para explicar fenômenos complexos. O objetivo da análise fatorial é, a partir de um conjunto de variáveis observáveis, identificar fatores latentes que não são diretamente observáveis. Hair et al. (1998) afirmam que as hipóteses subjacentes à análise fatorial são 
mais conceituais do que estatísticas. Dessa forma, uma análise fatorial eficaz deve possuir fatores simples e interpretáveis.

A hipótese básica da análise fatorial é a de que no conjunto de indicadores escolhidos/testados existem as dimensões latentes que se deseja obter/identificar. Assim, é de responsabilidade do pesquisador se assegurar de que os fatores extraídos são conceitualmente válidos (HAIR et al.,1998).

A análise de componentes principais é um passo realizado antes da rotação dos fatores da análise fatorial. Consiste num modelo de análise em que os fatores são baseados nas variâncias explicadas de todas as variáveis do modelo. Assim a soma das variações explicadas de cada variável pelos fatores é igual a um.

Hair et al.,(1998) apresentam uma série de critérios para se decidir acerca do número de fatores que devem ser extraídos/considerados numa análise fatorial. O critério mais comum para se decidir acerca do número de fatores que devem ser extraídos, ou considerados, numa análise fatorial é o do "auto-valor". Considerando-se que cada variável contribui com um valor de um, que é o valor dela mesma tomada isoladamente, para a explicação de um determinado fator; é usual se aceitar somente aqueles fatores que possuem um "auto-valor" maior que um. Esse critério é o que foi adotado neste trabalho.

Os mesmo autores também apontam a porcentagem da variância total explicada pelos fatores como um critério a ser adotado. Este deve ser utilizado quando se deseja explicar uma determinada proporção esperada, geralmente no campo das ciências naturais.

Após a definição de quantos fatores devem ser considerados, é necessário se determinar quais indicadores são utilizados na interpretação do significado de cada fator. Para isso, deve-se levar em conta a carga fatorial dos indicadores em relação a cada fator extraído. Um passo anterior é retirar da análise aqueles indicadores que possuem comunalidade menor que 0,50 , ou que não possuam carga fatorial de $0,30 \mathrm{com}$ nenhum fator extraído. Esse procedimento permite que a análise fatorial alcance um valor maior na variância total explicada. Um procedimento alternativo pode ser o de ignorar, na análise, as variáveis que não possuem comunalidade aceitável (HAIR et al., 1998).

Os mesmos autores destacam que a carga mínima deve ter um nível na casa de 0,30, assim para se nomear os fatores latentes, devem ser consideradas apenas as variáveis que possuem cargas fatoriais aceitáveis. Geralmente os pacotes estatísticos classificam as variáveis por ordem decrescente de cargas fatoriais de cada aspecto, devendo-se considerar as com cargas menores. 
A análise fatorial possui a hipótese básica de que um conjunto de indicadores possui algumas dimensões latentes que podem ser inferidas a partir desse conjunto de indicadores. Com o agrupamento desse conjunto de indicadores se permitirá medir, através dos escores fatoriais, a presença de cada dimensão nos indivíduos respondentes.

Dessa forma, apresenta-se a tabela 15 com os resultados da análise fatorial das variáveis/indicadores e questões do instrumento de pesquisa.

Tabela 15 - Análise Fatorial dos conjuntos de indicadores e questões

\begin{tabular}{|c|c|c|}
\hline Fator & Categoria & Questão \\
\hline 4 & Liderança & Q2 \\
\hline 4 & Liderança & Q3 \\
\hline 2 & Liderança & Q4 \\
\hline 2 & Liderança & Q5 \\
\hline 4 & Liderança & Q6 \\
\hline 2 & Liderança & Q7 \\
\hline 2 & Liderança & Q8 \\
\hline 2 & Liderança & Q9 \\
\hline 4 & Liderança & Q10 \\
\hline 4 & Liderança & Q11 \\
\hline 4 & Liderança & Q12 \\
\hline 2 & Liderança & Q13 \\
\hline 2 & Liderança & Q14 \\
\hline 4 & Liderança & Q15 \\
\hline 3 & Gestão de Pessoas & Q16 \\
\hline 3 & Gestão de Pessoas & Q17 \\
\hline 1 & Gestão de Pessoas & Q18 \\
\hline 3 & Gestão de Pessoas & Q19 \\
\hline 3 & Gestão de Pessoas & Q20 \\
\hline 1 & Gestão de Pessoas & Q21 \\
\hline 1 & Gestão de Pessoas & $\mathrm{Q} 22$ \\
\hline 1 & Gestão de Pessoas & Q23 \\
\hline 1 & Gestão de Pessoas & Q24 \\
\hline 1 & Gestão de Pessoas & Q25 \\
\hline 1 & Gestão de Pessoas & Q26 \\
\hline 1 & Gestão de Pessoas & Q27 \\
\hline 1 & Gestão de Pessoas & Q28 \\
\hline 1 & Aspectos Organizacionais & Q29 \\
\hline 1 & Aspectos Organizacionais & Q30 \\
\hline 1 & Aspectos Organizacionais & Q31 \\
\hline 3 & Aspectos Organizacionais & Q32 \\
\hline 3 & Aspectos Organizacionais & Q33 \\
\hline 5 & Aspectos Biológicos & Q34 \\
\hline 5 & Aspectos Biológicos & Q35 \\
\hline 5 & Aspectos Biológicos & Q36 \\
\hline 5 & Aspectos Biológicos & Q37 \\
\hline 6 & Aspectos Biológicos & Q38 \\
\hline 1 & Aspectos Psicológicos & Q39 \\
\hline 3 & Aspectos Psicológicos & Q40 \\
\hline 1 & Aspectos Psicológicos & Q41 \\
\hline
\end{tabular}




\begin{tabular}{|c|c|c|}
\hline 1 & Aspectos Psicológicos & Q42 \\
\hline 6 & Aspectos Psicológicos & Q43 \\
\hline 5 & Aspectos Sociais & Q44 \\
\hline 5 & Aspectos Sociais & Q45 \\
\hline 5 & Aspectos Sociais & Q46 \\
\hline 1 & Aspectos Sociais & Q47 \\
\hline 3 & Aspectos Sociais & Q48 \\
\hline
\end{tabular}

No grupo de questões da variável liderança, encontraram-se dois fatores, denominados número 2 e 4 . O número dois está relacionado às questões 4, 5, 7, 8, 9, 13 e 14. São questões envolvendo as formas de comunicações internas, feedback e auxílio para consecução dos resultados. Dessa forma, denominou-se esse fator dois como comunicação.

O fator 4 engloba as demais questões de liderança, sendo: 2, 3 6, 10, 11, 12 e 15. Envolve os esforços para se atingir os resultados da organização. Denominou-se como fator quatro de resultados.

No grupo de questões gestão de pessoas, encontrou-se dois fatores, denominados número 1 e 3 . O número um está relacionado às questões 18,21 a 28 . São questões envolvendo as formas de recompensas, carreira, avaliação etc. Denominou-se esse fator um como remuneração. O fator três é representado pelas questões 16, 17, 19 e 20 chamou-se o fator três de organização do trabalho.

Os aspectos organizacionais tiveram o fator um, nas questões 29,30 e 31 e o fator 3 nas questões 32 e 33. Os aspectos biológicos envolveram assuntos relacionados com saúde, convênio médico, doenças. Denominou-se o fator cinco como saúde ocupacional.

Nos aspectos psicológicos identificaram-se três fatores (1, 3 e 6). A questão 43 envolveu a maneira como o funcionário se sente no final da jornada de trabalho, assim como a questão 38. Foi definido como fator seis - fadiga do trabalho.

No último grupo, dos aspectos sociais, mensurou-se três fatores (1, 3 e 5). As questões 44, 45 e 46 envolveram a qualidade de convênios, lazer e previdência privada.

Na tabela 16 está identificada a distribuição das categorias de questões nos fatores determinados na análise fatorial e denominados anteriormente.

Tabela 16 - Distribuição das categorias em cada um dos fatores

\begin{tabular}{l|l|l|l|l|l|l}
\hline Composição absoluta de cada fator & \multicolumn{7}{c}{ Fatores } \\
\hline \multicolumn{1}{c|}{ Categorias } & $\mathbf{1}$ & $\mathbf{2}$ & $\mathbf{3}$ & $\mathbf{4}$ & $\mathbf{5}$ & $\mathbf{6}$ \\
\hline Liderança & 0 & 7 & 0 & 7 & 0 & 0 \\
\hline Gestão de Pessoas & 9 & 0 & 4 & 0 & 0 & 0 \\
\hline Aspectos Organizacionais & 3 & 0 & 2 & 0 & 0 & 0 \\
\hline
\end{tabular}




\begin{tabular}{l|c|c|c|c|c|c}
\hline Aspectos Biológicos & 0 & 0 & 0 & 0 & 4 & 1 \\
\hline Aspectos Psicológicos & 3 & 0 & 1 & 0 & 0 & 1 \\
\hline Aspectos Sociais & 1 & 0 & 1 & 0 & 3 & 0 \\
\hline
\end{tabular}

Apresenta-se ainda, a composição de cada fator. A categoria liderança está distribuída no fator 2 (comunicação) e no fator 4 (resultados). A gestão de pessoas identificou-se no fator 1 (remuneração) e 3 (organização do trabalho). Os aspectos organizacionais estão nos fatores 1 e 3. Os biológicos nos fatores 5 (saúde ocupacional) e 6 (fadiga no trabalho). Os aspectos psicológicos estão distribuídos nos fatores 1, 3 e 6. Finalmente, encontram-se os aspectos sociais relacionados com os fatores 1,3 e 5 .

Tabela 17 - Relativização da distribuição das categorias dentro dos fatores

\begin{tabular}{lcccccc}
\hline \multicolumn{1}{c}{ Categorias } & \multicolumn{7}{c}{ Fatores } \\
\cline { 2 - 7 } & $\mathbf{1}$ & $\mathbf{2}$ & $\mathbf{3}$ & $\mathbf{4}$ & $\mathbf{5}$ & $\mathbf{6}$ \\
\hline Liderança & $0 \%$ & $100 \%$ & $0 \%$ & $100 \%$ & $0 \%$ & $0 \%$ \\
Gestão de Pessoas & $56 \%$ & $0 \%$ & $50 \%$ & $0 \%$ & $0 \%$ & $0 \%$ \\
Aspectos Organizacionais & $19 \%$ & $0 \%$ & $25 \%$ & $0 \%$ & $0 \%$ & $0 \%$ \\
Aspectos Biológicos & $0 \%$ & $0 \%$ & $0 \%$ & $0 \%$ & $57 \%$ & $50 \%$ \\
Aspectos Psicológicos & $19 \%$ & $0 \%$ & $13 \%$ & $0 \%$ & $0 \%$ & $50 \%$ \\
Aspectos Sociais & $6 \%$ & $0 \%$ & $13 \%$ & $0 \%$ & $43 \%$ & $0 \%$ \\
Total & $100 \%$ & $100 \%$ & $100 \%$ & $100 \%$ & $100 \%$ & $100 \%$ \\
\hline \multicolumn{7}{c}{ Fonte: Dados da pesquisa } \\
\end{tabular}

Na tabela 17 está a relativização da distribuição das categorias dentro dos fatores. A categoria liderança está distribuída $100 \%$ no fator 2 (comunicação) e $100 \%$ no fator 4 (resultados). Em relação à gestão de pessoas identificou-se no fator 1 (remuneração), 56\% e no fator 3 (organização do trabalho), 50\%. Os aspectos organizacionais nos fatores 1 com $19 \%$ e 3 com 25\%. Os aspectos biológicos nos fatores 5 (saúde ocupacional) com 57\% e 6 (fadiga no trabalho) com 50\%. Os aspectos psicológicos distribuídos nos fatores 1, 3 e 6 com $19 \%, 13 \%$ e $50 \%$ respectivamente. Os aspectos sociais relacionados com os fatores 1,3 e 5 com $6 \%, 13 \%$ e $43 \%$ nessa ordem.

Tabela 18 - Relativização da distribuição das categorias e como elas se distribuem nos fatores

\begin{tabular}{lccccccc}
\hline \multicolumn{1}{c}{ Categorias } & \multicolumn{7}{c}{ Fatores } \\
\cline { 2 - 8 } & $\mathbf{1}$ & $\mathbf{2}$ & $\mathbf{3}$ & $\mathbf{4}$ & $\mathbf{5}$ & $\mathbf{6}$ & Total \\
\hline Liderança & $0 \%$ & $50 \%$ & $0 \%$ & $50 \%$ & $0 \%$ & $0 \%$ & $100 \%$ \\
Gestão de Pessoas & $69 \%$ & $0 \%$ & $31 \%$ & $0 \%$ & $0 \%$ & $0 \%$ & $100 \%$ \\
Aspectos Organizacionais & $60 \%$ & $0 \%$ & $40 \%$ & $0 \%$ & $0 \%$ & $0 \%$ & $100 \%$ \\
Aspectos Biológicos & $0 \%$ & $0 \%$ & $0 \%$ & $0 \%$ & $80 \%$ & $20 \%$ & $100 \%$ \\
Aspectos Psicológicos & $60 \%$ & $0 \%$ & $20 \%$ & $0 \%$ & $0 \%$ & $20 \%$ & $100 \%$ \\
Aspectos Sociais & $20 \%$ & $0 \%$ & $20 \%$ & $0 \%$ & $60 \%$ & $0 \%$ & $100 \%$ \\
\hline \multicolumn{7}{c}{ Fonte: Dados da pesquisa }
\end{tabular}


Na tabela 18 está a relativização da distribuição das categorias e como elas se distribuem nos fatores. A categoria liderança está distribuída 50\% no fator 2 (comunicação) e $50 \%$ no fator 4 (resultados). Em relação à gestão de pessoas identificou-se no fator 1 (remuneração) 69\% e no fator 3 (organização do trabalho) 31\%. Os aspectos organizacionais nos fatores 1 com $60 \%$ e $3 \mathrm{com} 40 \%$. Os aspectos biológicos nos fatores 5 (saúde ocupacional) com $80 \%$ e 6 (fadiga no trabalho) com 20\%. Os aspectos psicológicos distribuídos nos fatores 1, 3 e 6 com 60\%, 20\% e 20\% respectivamente. Os aspectos sociais relacionados com os fatores 1,3 e 5 com $20 \%, 20 \%$ e $60 \%$ nessa ordem.

Foram realizadas as comunalidades, proporção da variabilidade de cada questão, que é explicada pelo modelo de Análise Fatorial (AF). São apresentadas as comunalidades das questões de pesquisa no Apêndice 4.

Na questão 2, obteve-se a comunalidade de 0,41 , ou seja, $41 \%$ da variabilidade das respostas da questão 2 foram explicadas pelo modelo de AF. Na questão 37, a comunalidade foi de 0,601 , significando que $60 \%$ da variabilidade das respostas da questão 37 foram explicadas pelo modelo de Análise Fatorial.

Na questão 43 (satisfação da jornada de trabalho e fadiga) a comunalidade foi de 0,005, significa que $0,5 \%$ da variabilidade das respostas da questão 43 foi explicada pelo modelo de AF, com o resultado inferior de todas as questões do instrumento de pesquisa.

$\mathrm{Na}$ questão 46, que envolvia a satisfação com a qualidade da previdência privada, a comunalidade foi de 0,66 , ou seja, $66 \%$ da variabilidade das respostas da questão 46 foram explicadas pelo modelo de Análise Fatorial, com o resultado mais elevado das 48 questões do instrumento de pesquisa.

Em relação às hipóteses iniciais de trabalho que foram testadas na pesquisa, verifica-se que:

$\mathrm{H}_{0}$ - Não existe relação entre qualidade de vida no trabalho e gestão estratégica de pessoas e liderança.

A análise foi desenvolvida de maneira conjunta, isto é, levando em consideração as estruturas de correlação entre todas as variáveis. Isso é o que a "relação multivariada" efetiva. O Lambda de Wilks testa essa hipótese. Ela é rejeitada, afirma-se então, que existe de fato, alguma relação. Depois, identificou-se cada possível relação da MANOVA e analisaram-se os "p-valores" ou também denominados "valor p". 
Após a confirmação, ou não dessas hipóteses, esta pesquisa busca estabelecer comparações entre grau de satisfação com qualidade de vida, gestão de pessoas e liderança orientada para resultados nas duas instituições financeiras analisadas.

$\mathrm{H}_{1}$ - A proporção de pessoas que possuem alto grau de satisfação com qualidade de vida no trabalho é a mesma nas duas instituições;

$\mathrm{H}_{2}$ - A proporção de pessoas que concordam com a gestão estratégica de pessoas de comprometimento (transformada) é a mesma nas duas instituições;

$\mathrm{H}_{3}$ - A proporção de pessoas que atribuem importância à liderança orientada para resultados é a mesma nas duas instituições.

Desse modo, REJEITA-SE TODAS AS HIPÓTESES ANTERIORES.

Para todas essas hipóteses, olha-se para as análises dos p-valores (com a mesma noção teórica: se p-valor $<5 \%$, rejeita-se) das estatísticas de teste qui-quadrado de cada tabela. Nota-se que todos os p-valores são muito baixos, indicando que a percepção não é a mesma nas duas instituições.

Portanto, as hipóteses foram rejeitadas; percebe-se que todos os "valores p" são menores do que $5 \%$. Isto representa que existe associação entre os fatores de estudo e mostrou que o comportamento perceptivo dos bancos é diferente.

A primeira hipótese, que era da proporção de pessoas que possuem alto grau de satisfação com qualidade de vida no trabalho, não é a mesma nas duas instituições, visto que na instituição Alfa a satisfação é superior em relação à Beta.

A proporção de pessoas que concordam com a gestão estratégica de pessoas de comprometimento (transformada) não é a mesma nas duas instituições, pois no banco Alfa o grau de concordância com a gestão transformada é maior.

A última hipótese da proporção de pessoas que atribuem importância à liderança orientada para resultados não é a mesma nas duas instituições, visto que a importância é maior nesse constructo na instituição Alfa em relação à Beta.

Após as análises fatoriais e teste de hipóteses, o próximo item estão apresentados as relações multivariadas. 


\subsection{Relações Multivariadas}

Análise multivariada refere-se a todos os métodos que analisam simultaneamente múltiplas medidas em cada indivíduo ou objeto sob investigação. O propósito da análise multivariada é medir, explicar e predizer o grau de relação entre variáveis.

Tabela 19 - Significância multivariada dos fatores

\begin{tabular}{ccccc}
\hline & Graus de Liberdade & Lambda de Wilks & F aproximado & valor-p \\
\hline Gestão de Pessoas & 1 & 0,303 & 86,297 & $<0,001$ \\
Liderança & 1 & 0,938 & 2,486 & 0,046 \\
Resíduos & 153 & & & \\
\hline
\end{tabular}

Fonte: Dados da pesquisa

De acordo com a Tabela 19 e adotando um nível de significância de 5\%, observa-se que as variáveis propostas (Gestão de Pessoas e Liderança) estão conjuntamente relacionadas com as variáveis propostas para QVT. Além disso, nota-se que "Gestão de Pessoas" está mais fortemente associada com as respostas devido ao nível de significância.

O valor (p) da probabilidade de se observar valores mais extremos é significante em gestão de pessoas e liderança.

Análise de Variância Multivariada (MANOVA) é a técnica estatística que pode ser usada para simultaneamente explorar a relação entre diversas variáveis independentes categóricas (tratamentos) e duas ou mais variáveis dependentes métricas.

A análise multivariada é a extensão das técnicas univariadas para acessar diferenças entre grupos de médias

As estimativas são dadas a seguir:

Tabela 20 - Estimativas dos coeficientes da MANOVA - Fator Aspectos Biológicos

\begin{tabular}{cccc}
\hline & Estimativa & Erro-Padrão & Valor-p \\
\hline Intercepto & 0,435 & 0,063 & $<0,001$ \\
Gestão de Pessoas & 0,408 & 0,094 & $<0,001$ \\
Liderança & 0,110 & 0,101 & 0,279 \\
\hline $\mathrm{R}^{2}: 0,2286$ & \multicolumn{3}{c}{}
\end{tabular}

Segundo a tabela 20, a gestão de pessoas é importante para explicar a variação da QVT, ou seja, pode-se inferir que quanto mais investimento a instituição financeira realizar em gestão de pessoas, melhor serão as satisfações com os aspectos biológicos.

$\mathrm{O}$ R2 $=22 \%$ da variabilidade das respostas em aspectos biológicos conseguiu ser explicada pelo modelo; não foi expressivo, mas foi significativo. 
Tabela 21 - Estimativas dos coeficientes da MANOVA - Fator Aspectos Organizacionais

\begin{tabular}{cccc}
\hline & Estimativa & Erro-Padrão & Valor-p \\
\hline Intercepto & $-0,005$ & 0,050 & 0,923 \\
Gestão de Pessoas & 0,790 & 0,074 & $<0,001$ \\
Liderança & 0,165 & 0,080 & 0,040 \\
\hline
\end{tabular}

$R^{2}: 0,6265$

Fonte: Dados da pesquisa

De acordo com a tabela 21 a gestão de pessoas é importante para explicar a variação da QVT, ou seja, pode-se inferir que quanto mais investimento a instituição financeira realizar em gestão de pessoas, melhor são as satisfações com os aspectos organizacionais.

O R2 $=62,65 \%$ da variabilidade das respostas em aspectos organizacionais conseguiu ser explicada pelo modelo; foi muito expressivo e significativo.

Tabela 22 - Estimativas dos coeficientes da MANOVA - Fator Aspectos Psicológicos

\begin{tabular}{cccc}
\hline & Estimativa & Erro-Padrão & Valor-p \\
\hline Intercepto & $-0,014$ & 0,058 & 0,812 \\
Gestão de Pessoas & 0,720 & 0,087 & $<0,001$ \\
Liderança & 0,271 & 0,093 & 0,004 \\
\hline $\mathrm{R}^{2}: 0,5547$ & & &
\end{tabular}

Fonte: Dados da pesquisa

A tabela 22 demonstra as estimativas dos coeficientes da MANOVA de gestão de pessoas para explicar a variação da QVT, ou seja, pode-se inferir que quanto mais investimento for realizado em gestão de pessoas, melhor são as satisfações com os aspectos psicológicos.

O R2 $=55,47 \%$ da variabilidade das respostas em aspectos psicológicos conseguiu ser explicada pelo modelo; foi muito expressivo e significativo.

Tabela 23 - Estimativas dos coeficientes da MANOVA - Fator Aspectos Sociais

\begin{tabular}{cccc}
\hline & Estimativa & Erro-Padrão & Valor-p \\
\hline Intercepto & 0,196 & 0,054 & $<0,001$ \\
Gestão de Pessoas & 0,515 & 0,080 & $<0,001$ \\
Liderança & 0,129 & 0,086 & 0,136 \\
\hline $\mathrm{R}^{2}: 0,3908$ & \multicolumn{3}{c}{}
\end{tabular}

Na tabela 23 observam-se as estimativas dos coeficientes da MANOVA de gestão de pessoas para explicar a variação da QVT, ou seja, pode-se inferir que, quanto mais investimento realizado em gestão de pessoas, melhor são as satisfações com os aspectos sociais.

O R2 $=39,08 \%$ da variabilidade das respostas em aspectos sociais conseguiu ser explicada pelo modelo; foi muito expressivo e significativo. 
De acordo com as tabelas 19 a 23, é possível observar que a magnitude da variável "Gestão de Pessoas" é sempre superior à magnitude da variável "Liderança". Nota-se que, a um nível de significância de 5\%, para todas as respostas, a variável "Gestão de Pessoas" está associada. Já "Liderança”, só está associada aos "Aspectos Organizacionais” e aos "Aspectos Psicológicos", ao mesmo nível de significância.

A interpretação dos coeficientes decorre imediatamente da definição do modelo proposto anteriormente. Observa-se que nas primeiras linhas das tabelas 20 a 23 estão computados os níveis de satisfação esperados quando as pessoas estão totalmente insatisfeitas (nível 0, em uma escala de 0 a 100\%), tanto em gestão de pessoas quanto em liderança.

\section{Gráfico 1 - Gráfico do tipo quantil-quantil para os resíduos do modelo}

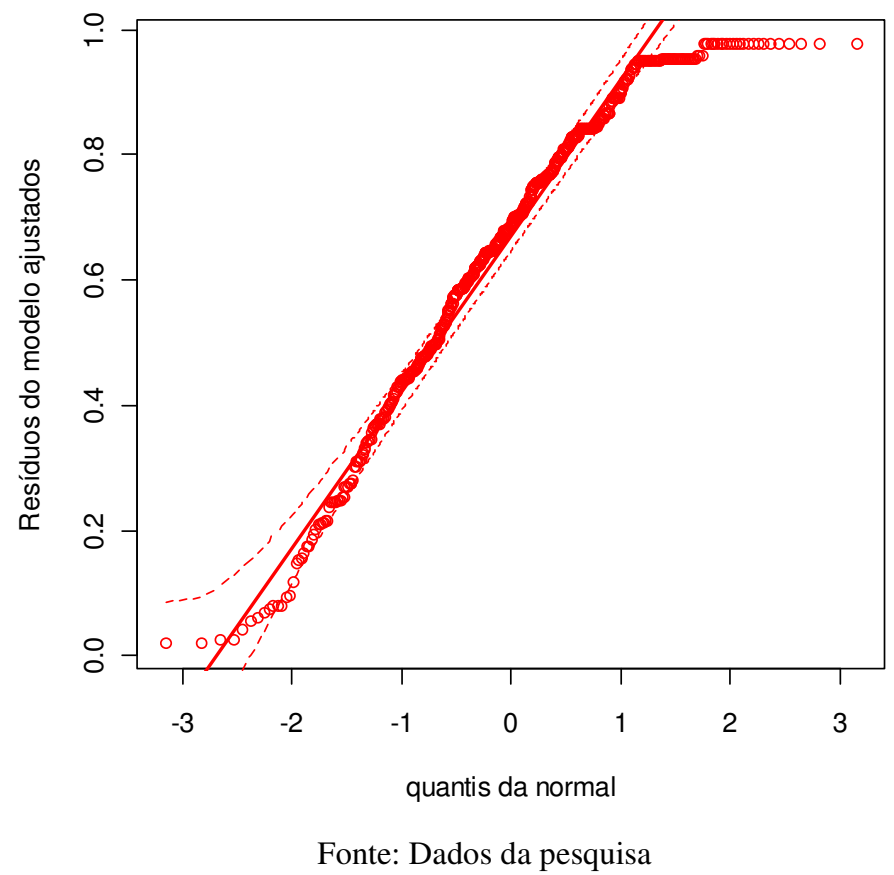

Pelo Gráfico 1, é possível afirmar que os resíduos sejam normais, apesar de a cauda direita não se ajustar bem à curva normal. Isso leva a crer em bons ajustes para níveis de satisfação até 0,9. Acima disso, as predições podem ser errôneas ou inconclusivas. Como o propósito é verificar associação e não fazer predições, pode-se considerar adequado o ajuste. 
CAPÍTULO 6- CONCLUSÃO

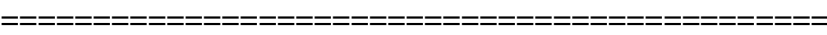


Este estudo teve como ponto inicial o objetivo de analisar o grau de importância da liderança orientada para resultados, na percepção dos profissionais da área de gestão de pessoas de duas Instituições Financeiras Internacionais, que atuam no Brasil e suas relações com a gestão estratégica de pessoas e com os níveis de satisfação dos aspectos organizacionais, biológicos, psicológicos e sociais.

Entende-se que foram atingidos os objetivos, pois se analisou a importância da liderança orientada para resultados e suas relações com a gestão de pessoas e com os aspectos da qualidade de vida no trabalho nas duas instituições financeiras.

Os principais resultados foram: a caracterização das instituições pesquisadas que são de capital internacional e suas matrizes mundiais sediadas na Europa; nas entrevistas semiestruturadas e nos questionários respondidos pelos funcionários da área identificou-se nas duas organizações políticas estruturadas de gestão de pessoas com relação ao recrutamento e seleção de pessoal, treinamento e desenvolvimento, cargos e salários, benefícios sociais, avaliação de desempenho e higiene e segurança no trabalho.

As políticas e práticas de gestão de pessoas são fundamentais para que os funcionários das empresas estejam envolvidos e comprometidos com os objetivos organizacionais. Essas políticas e práticas são a maneira das instituições lidarem com as pessoas, de atraí-las para a empresa, de integrá-las e orientá-las, desenvolvê-las, recompensá-las, avaliá-las e monitorálas, ou seja, a qualidade da maneira como as pessoas são geridas na organização é um dos pilares na competitividade organizacional.

Nesse sentido, Ulrich (1998, p. 34) destaca a importância das mudanças ambientais e das competências e práticas do gestor de pessoas:

[...] as transformações que estão ocorrendo em razão de fatores como a evolução da tecnologia, a globalização, crescimento lucrativo e demandas de consumo colocam em pauta os papéis que devem desempenhar os profissionais de recursos humanos, suas competências individuais e organizacionais que podem ser ampliadas através da execução eficaz de práticas de Gestão de Pessoas.

As características demográficas dos respondentes da pesquisa por instituição financeira são: maioria dos participantes é composta de técnicos, analistas ou auxiliares; são, mulheres, jovens até 35 anos, possuem superior completo ou são pós-graduados e não possuem dependentes. Isso representa que os funcionários das áreas de gestão de pessoas nessas organizações são jovens e com escolaridade elevada, seguindo o perfil dos bancários pesquisados pela Febraban (2007), em vinte e oito instituições financeiras. 
Em relação à liderança para resultados, de acordo com os respondentes, o banco Alfa é mais orientado em comparação ao banco Beta e os líderes são mais motivados com a obtenção de resultados positivos, assim como o cumprimento individual das expectativas na instituição Alfa obteve a maior proporção nesse aspecto, sendo inclusive, superior ao Beta.

O sistema financeiro nos últimos vinte anos sofreu mudanças no seu papel inicial de prestador de serviços bancários para um ponto de venda de seguros, capitalização, empréstimos, financiamentos, cartão de crédito entre outros. Algumas organizações são mais agressivas em resultados em comparação a outras como é o caso dos bancos privados internacionais analisados - bancos Alfa e Beta.

Em relação à satisfação com os aspectos organizacionais, foram destaque a imagem do banco junto aos bancários e as oportunidades de treinamento com proporções superiores na instituição Alfa.

As instituições financeiras possuem sistemas de comunicação interna efetivos como intranet, boletins informativos, revistas da organização, reuniões periódicas, comitês informativos e decisoriais, entre outros.

No aspecto biológico o atendimento do convênio médico/saúde obteve a maior proporção de satisfação nas duas instituições, e no psicológico, as oportunidades de carreira obtiveram os maiores resultados nas instituições analisadas.

Constatou-se que os bancos investem na prevenção e controle dos riscos relacionados a LER/DORT e no convênio médico, como apontado na pesquisa da Febraban (2007). Em relação a DORT é uma exigência da legislação; como destacado por Handar, Mendes e Facci (2004), as organizações devem gerir programas consistentes de prevenção contra riscos ocupacionais como: físicos, químicos, biológicos, ergonômicos e de acidentes, como rege a própria norma regulamentadora (N.R.) de número cinco.

Apurou-se resultados gerais mais baixos no aspecto social. Isso é decorrente da falta de políticas estruturadas de previdência complementar no banco Beta, causando insatisfação nesse item.

A gestão da qualidade de vida no trabalho é fundamental para que os colaboradores estejam satisfeitos com a instituição nas condições físicas, biológicas, psicológicas e organizacionais adequadas para o desempenho de suas atividades.

De acordo com Gonçalves (1998, p. 30), "sendo possível medir a qualidade de vida no trabalho, será possível gerí-la, e pode-se medí-la com grande facilidade”. 
As correlações apontaram que a determinação do que o funcionário deve fazer para melhorar os resultados finais e o envolvimento em atividades e oportunidades de desenvolvimento que ajudam a produzir melhores resultados têm uma correlação com a comunicação interna das metas e objetivos. O envolvimento em atividades e oportunidades de desenvolvimento que ajudam a produzir melhores resultados tem uma correlação com a determinação do que o funcionário deve fazer para melhorar os resultados finais.

Esses resultados eram esperados, pois na medida que a comunicação é efetiva, ela contribui para o alcance dos resultados, metas e objetivos. Nesse sentido, as oportunidades de qualificação e desenvolvimento contribuem para o alcance dos resultados, pois os funcionários estarão mais preparados e treinados para as tarefas.

A satisfação com as oportunidades de carreira tem uma correlação com grupos de variáveis, como gestão estratégica de pessoas, aspectos organizacionais e psicológicos. Os aspectos psicológicos apresentam uma correlação da satisfação com as oportunidades de carreira e participação.

A gestão estratégica de pessoas estruturada com políticas de carreira, participação e desenvolvimento, contribui com a motivação intrínseca dos funcionários, pois é fundamental para seu desenvolvimento, realização pessoal e profissional.

É relevante o entendimento de Facchini e Bigneti (2004, p. 1), onde a gestão de pessoas assume papel central e estratégico no desempenho das empresas. "A manutenção de um padrão elevado de desempenho exige flexibilidade, inovação e agilidade, características necessárias para a manutenção da vantagem competitiva e que decorrem basicamente dos recursos e capacidades internas de cada organização.”

As hipóteses iniciais de trabalho foram testadas na pesquisa e todas foram rejeitadas, chegando-se às seguintes conclusões:

- Existe relação entre qualidade de vida no trabalho e gestão estratégica de pessoas e liderança, pois a correlação apurou que a gestão de pessoas tem correlações altas com os aspectos identificados;

- a proporção de pessoas que possuem alto grau de satisfação com qualidade de vida no trabalho não é a mesma nas duas instituições; visto que na instituição Alfa a satisfação é superior em relação à Beta;

- a proporção de pessoas que concordam com a gestão estratégica de pessoas de comprometimento (transformada) é diferente nas duas instituições, pois no banco Alfa o grau de concordância com a gestão transformada é maior; 
- a proporção de pessoas que atribuem importância à liderança orientada para resultados não é a mesma nas duas instituições, visto que a importância é maior nesse aspecto na instituição Alfa do que em relação a Beta.

Nesse sentido, Ulrich (1998, p. 33) afirma que "existem quatro maneiras pelas quais os profissionais de recursos humanos adicionam valor a uma empresa: ajudando na execução de uma estratégia, construindo uma infra-estrutura, garantindo contribuição dos funcionários e gerindo a transformação e a mudança”.

De acordo com Limongi-França (2007, p. 36), "na complexa rede de influências entre as expectativas pessoais, organizacionais e econômicas -, a gestão da qualidade de vida no trabalho pode ser o eixo central dos dilemas de bem-estar e mal-estar das pessoas em suas organizações". Ainda segundo a autora, a gestão da qualidade de vida é "construída a partir de uma visão específica de pessoa no trabalho, sustentada pelas práticas e valores biopsicossociais, originários da abordagem psicossomática".

Os resultados da pesquisa apontaram algumas limitações, contribuições e a necessidade que este trabalho seja complementado com outros estudos, como apresentado a seguir.

\subsection{Limitações do estudo}

O estudo realizado com profissionais de gestão de pessoas em duas instituições financeiras internacionais, exploratório, não permite a generalização das conclusões para todas as áreas desses bancos investigados e nem para outras organizações brasileiras ou internacionais.

Por tratar-se de um assunto não estudado com essas relações (liderança orientada para resultados, gestão estratégica de pessoas e satisfação com os aspectos organizacionais, biológicos, psicológicos e socais), optou-se pela abordagem exploratória, objetivando levantar mais informações que possam embasar estudos futuros. Os resultados encontrados podem contribuir para futuras pesquisas visando o entendimento e a ligação entre os temas investigados.

A abordagem metodológica quantitativa encontra limitações para explicações dos resultados, pois não investiga os assuntos em profundidade. Por isso, optou-se por realizar algumas entrevistas semi-estruturadas com alguns respondentes da primeira pesquisa para esclarecer algumas lacunas encontradas nos resultados dos questionários. 
Nota-se que a gestão de pessoas e liderança estão conjuntamente relacionadas com as variáveis propostas para QVT. Pode-se inferir que quanto mais investimento a instituição financeira realizar em gestão de pessoas, melhor são as satisfações com os aspectos biológicos, organizacionais, psicológicos e sociais.

Pode-se concluir que as duas instituições financeiras analisadas têm forte orientação para liderança de resultados, com políticas estruturadas de gestão estratégica de pessoas com foco no comprometimento (transformada) e visam a satisfação dos funcionários com os aspectos da qualidade de vida no trabalho.

\subsection{Contribuições do estudo}

Nesse sentido, pode-se inferir que nas organizações analisadas existem estágios diferentes de gestão de pessoas, pois a instituição Alfa está consolidada nas políticas de gestão de pessoas e o banco Beta está na fase de reestruturação devido às fusões recentes, com práticas diferenciadas para funcionários originários de organizações distintas, causando satisfações inferiores aos do Alfa.

As principais contribuições deste trabalho são para o entendimento do tema ora estudado e para identificação da dinâmica da gestão de pessoas nas instituições pesquisadas. Para a comunidade científica é importante o estudo, pois se verificou como esses constructos se relacionam e como podem contribuir para os resultados das organizações e para a qualidade de vida no trabalho dos seus colaboradores.

Para as organizações de maneira geral é relevante este trabalho, pois os dados da pesquisa demonstraram que quanto maior for o investimento em políticas de gestão estratégica de pessoas com visão transformada, maior será a satisfação com os aspectos da qualidade de vida no trabalho.

\subsection{Recomendações para estudos futuros}

Outros estudos podem ser realizados para contribuir para o entendimento dos processos de liderança, gestão estratégica de pessoas e qualidade de vida no trabalho nas organizações em que os colaboradores são o diferencial competitivo.

Futuros estudos poderão ser desenvolvidos em outras áreas dos bancos múltiplos investigados e demais instituições do sistema financeiro nacional, bem como em outros tipos 
de organizações como: indústrias, comércio, prestação de serviços, organizações do terceiro setor, organizações públicas, cooperativas, universidades, entre outras.

Sugerem-se estudos qualitativos com os líderes e liderados nas diversas organizações e estudos longitudinais para verificar essas correlações no decorrer do tempo.

Poderiam ser realizados estudos com instituições financeiras em outros países e continentes para analisar as diferentes culturas e a orientação para a liderança de resultados relacionada com as políticas de gestão de pessoas e os aspectos da qualidade de vida no trabalho. 
REFERÊNCIAS

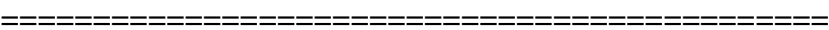


AGLE, B. R.; NAGARAJAN, N. J.; SONNENFELD, J. A.; SRINIVASAN, D. Does CEO charisma matter? An empirical analysis of the relationships among organizational performance, environmental uncertainty, and top management team perceptions of CEO charisma. Academy of Management Journal. 2006, vol. 49, n. 1, 161-174.

ALBERTO, S.; STEFANO, S. R.; NEVES, A. B. Os sistemas de administração de pessoas: um estudo comparativo. Caderno de Administração. Maringá, v. 10, n. 1, jan/jun, 2002.

ALBORNOZ, S. O que é trabalho. São Paulo: Brasiliense, 2002.

ALBUQUERQUE, L. G. Estratégias de recursos humanos e competitividade. In: Vieira, M. M. F.; OLIVEIRA, L. M. B. (Orgs.) São Paulo: Atlas, 1999.

ALBUQUERQUE, L. G. A gestão estratégica de pessoas. In: FLEURY, M. T. L (Org.). As pessoas na organização. São Paulo: Editora Gente, 2002. p. 35-50.

ANDREWS, K. R. The concept of corporate strategy. Brookfield: Darthmouth, 1977.

ANSOFF, H. I. A nova estratégia empresarial. São Paulo: Atlas, 1990.

ANTHONY, W. P.; PERREWÉ, P. L.; KACMAR, M. K. Strategic human resource management. Flórida: Harcourt Brace Publishers \& Co., 1996.

ANTUNES, R. Os sentidos do trabalho: ensaio sobre a afirmação e a negação do trabalho. São Paulo: Boitempo Editorial, 1999.

ARAÚJO, L. C. G. de Gestão de Pessoas: Estratégias e integração organizacional. São Paulo: Atlas, 2006.

AROMA, W.; DA SILVA, A. C. A Influência dos Líderes na Melhoria dos Serviços de Atendimento em Agências Bancárias Atuando no Processo de Aprendizagem dos Atendentes. In: ENANPAD, 2003, Atibaia SP. (Anais... Atibaia: s.n., 2003).

BANCO CENTRAL DO BRASIL. Brasília, 2008. Disponível em: < http://www.bancocentral.gov.br/?QEVSFN200705>. Acesso em 07 set. 2008.

BECKER, B. E.; HUSELID, M. A.; ULRICH, D. Gestão estratégia de pessoas com "scorecard". Rio de Janeiro: Elsevier, 2001.

BENEDETTI, M. H.; HANASHIRO, D. M. M.; POPADIUK, S. Líderes e Liderados: uma Relação com Base no Gerenciamento de Stakeholders. In: ENANPAD, 2003, Atibaia SP. (Anais...Atibaia: s.n., 2003).

BERGAMINI, C. W. Liderança Administração do Sentido. São Paulo: Atlas, 1994.

O líder eficaz. São Paulo: Atlas, 2002.

BENNIS, W. O futuro da liderança. São Paulo: Futura, 2001.

BITENCOURT, C. Gestão contemporânea de pessoas: novas práticas, conceitos tradicionais. Porto Alegre: Bookman, 2004.

BOWDITCH, J. L.; BUONO, A. F. Elementos do comportamento organizacional. São Paulo: Pioneira Thomson, 2002. 
CARMO, P. S. A ideologia do trabalho. 6.ed. São Paulo: Moderna, 1997.

CARVAlHO, A. V; SERAFIM, O. C. G. Administração de Recursos Humanos. São Paulo: Pioneira, 2001.

COHEN, A. R.; FINK, S. L. Comportamento organizacional: Conceitos e estudos de casos. Rio de Janeiro: Campus, 2003.

COLLIS, J,; HUSSEY, R. Pesquisa em administração: um guia prático para alunos de graduação e pós-graduação. Porto Alegre: Bookman, 2005.

CONGER, J. A.; FULMER, R. M. Developing Your Leadership Pipeline. Harvard Business Review, v. 81, n.12, dez. 2003. p.76-84.

COOPER, D. R.; SCHINDLER, P. S. Business Reserch Methods. Irwin: McGraw-Hill, 1995.

COVEY, S. R. $\mathbf{O ~ 8}^{\mathbf{0}}$ Hábito - da eficácia a grandeza. São Paulo: Campus, 2005.

CURY, A. J. Análise da inteligência de Cristo: o Mestre dos Mestres. São Paulo: Academia da Inteligência, 1999.

DAFT. R. I. Administração. Rio de Janeiro: LTC, 1999.

DANNA, K.; GRIFFIN, R. W. Health and well-being in the workplace: a review and synthesis of the literature. Jornal of Management. v. 25, n. 1, p. 357-375, 1999.

DIAS, G. S. Gestão estratégica de pessoas através da Qualidade de Vida no Trabalho: o nível de satisfação de professores de administração de empresas de uma universidade pública e uma privada. Estratégias para o Desenvolvimento e Inserção Global. In: Congresso LatinoAmericano de Estratégias, 18, 2004, Itapema. Anais... Itapema: s.n., 2004.

DIENER, E. Subjective well-being: the science of happiness and a proposal for a national indes. Amerciam Psychologist. v. 55, p. 34-43, 2000.

DUBRIN, A. J. Leadership. Research Findings, Practice, and Skills. Houghton Mifflin Company. Boston, 1998.

DUTRA, I. S.; SANTOS, L. M. L.; CAMARA, M. R. G.; STEFANO, S. R. Bancos múltiplos: Bradesco, Itaú e Unibanco: um estudo de indicadores e estratégias. Caderno de Administração, Maringá, v. 9, n. 1, p. 77-100, jan./jun.2001.

EISENHARDT, K. M. Building theories from case study research. The Academy of Management Review. v. 14, n. 4, p. 532-550, oct. 1989.

ENCICLOPÉDIA Mirador Internacional. São Paulo: Encyclopedia Britannica do Brasil Publicações, 1989.

FACCHINI, A. R.; BIGNETTI, L. P. O Papel do Executivo e o Alcance das Práticas de RH: o Desafio da Eficácia. In: Encontro Nacional de Pós-Graduação e Pesquisa em Administração ENANPAD, Anais... Curitiba, PR: 2004.

FEBRABAN - Federação Brasileira de Bancos. São Paulo, 2007. Disponível em: $<$ www.febraban.org.br>. Acesso em 23 ago. 2007. 
FERNANDES, E. C. Qualidade de vida no trabalho. 3 ed.. Salvador: Casa da Qualidade, 1996.

FISCHER, R. M.; FLEURY, M. T. L. Cultura e poder nas organizações. São Paulo: Atlas, 1992.

FLEURY, M. T. L.; SAMPAIO, J. R. Uma discussão sobre cultura organizacional. In: FLEURY, M. T. L. (coord.). As pessoas na organização. 6. ed. São Paulo: Gente, 2002.

FLICK, U. Uma introdução à pesquisa qualitativa. Porto Alegre: Bookman, 2005.

GIANNETTI, E. Felicidade: diálogos sobre o bem-estar na civilização. São Paulo: Companhia das Letras 2002.

GIDDENS, A. Mundo em descontrole: o que a globalização está fazendo de nós. Rio de Janeiro: Record, 2000.

GODOY, A. S. Estudo de caso qualitativo. In: GODOI, C. K; BANDEIRA-DE-MELLO, R.; SILVA, A. B. (orgs.) Pesquisa qualitativa em estudos organizacionais: paradigmas, estratégias e métodos. São Paulo: Saraiva, 2006.

GOLEMAN, D. Liderança que Obtém Resultados. In: Harvard Business Review on What Makes a Leader. Rio de Janeiro: Campus, 2002. p. 55-84.

GONÇALVES, C. F. F. Ergonomia e Qualidade nos Serviços: Uma Metodologia de Avaliação. Londrina: UEL, 1998.

GORDON, J. R. A Diagnostic Approach to Organizational Behavior, Boston: Allyn \& Bacon, 2001.

GOULART, I. B.; SAMPAIO, J. R. Qualidade De Vida No Trabalho: uma análise da experiência de empresas brasileiras. In: SAMPAIO, J. R. (Org.). Qualidade de Vida no Trabalho e Psicologia Social. São Paulo: Editora Casa do Psicólogo, 2004.

GREEN, S.; HASSAN, F.; IMMELT, J.; MARKS, M.; MEILAND, D. In Search of Global Leader. Harvard Business Review, v. 81, n.8, ago. 2003. p.38-44.

HACKMAN, J. R.; OLDHAM, G. R. Development of the job diagnostic survey. Journal of Applied Psychology, v. 60, n. 2, p. 159-70, 1975.

HAIR et al. Multivariate data analysis. New Jersey: Prentice Hall, 1998.

HALL, R. H. Organizações: estrutura e processos. Rio de Janeiro: P. H. B., 1984.

HANDAR, Z.; MENDES, R.; FACCI, R. O Desafio da Equidade em Saúde e Segurança no Trabalho. Editora VK: São Paulo, 2004.

HITT, M. A.; IRELAND, R. D.; HOSKISSON, R. E. Strategic Management: competitiveness and globalization. Ohio: Thomson South-Western, 2005.

HITT, M. A.; MILlER, C. C.; COLELlA, A. Comportamento organizacional: uma abordagem estratégica. Rio de Janeiro: LTC, 2007.

HOFSTEDE, G. Cultures consequences: International diffeences in work-related values. Beverly Hills, CA: Sage, 1980. 
HOFSTEDE, G. Culturas e organizações: compreender a nossa programação mental. Lisboa: Edições Silabo, Lda, 2003.

HOWELL, J. M.; SHAMIR, B. The role of followers in the charismatic leadership process: relationships and their consequences. Academy of Management Review. 2005, vol. 30, n.1, 96-112.

INFOPÉDIA. Enciclopédia e Dicionários Porto Editora, 2007. Disponível em: <http://www.infopedia.pt/pesquisa?qsFiltro=0>. Acesso em 02 set. 2007.

IBGE - Instituto Brasileiro de Geografia e Estatística. http://www.ibge.gov.br/ Acesso em 26 ago. 2008.

JOHANN, S. L. Gestão da cultura corporativa: como as organizações de alto desempenho gerenciam sua cultura organizacional. São Paulo: Saraiva, 2004.

LACOMBE, F.; HEILBORN, G. Administração: princípios e tendências. São Paulo: Saraiva, 2003.

LIKERT, R. A Organização Humana. São Paulo: Atlas, 1975.

LIMA, C. H. P.; VIEIRA, A. Do Sacrifício ao Sacro Ofício: um Modelo Para a Compreensão do Significado Do Trabalho. In: ENCONTRO DA ASSOCIAÇÃO NACIONAL DOS PROGRAMAS DE PÓS-GRADUAÇÃO EM ADMINISTRAÇÃ̃O, 29., 2005, Brasília. Anais... Brasília: ENANPAD, 2005.

LIMONGI-FRANÇA, A. C. Indicadores Empresariais de Qualidade de Vida no

Trabalho: esforço empresarial e satisfação dos empregados no ambiente de manufaturas com certificação ISO 9000. Tese de Doutorado. São Paulo: FEA/USP, 1996.

LIMONGI-FRANÇA, A. C.; ARELLANO, E. B. Liderança, poder e comportamento organizacional. In: FLEURY, M. T. L (Org.). As pessoas na organização. São Paulo: Editora Gente, 2002. p. 259-269.

LIMONGI-FRANÇA, A. C. Qualidade de Vida no Trabalho - conceitos e práticas nas empresas da sociedade pós-industrial. São Paulo: Editora Atlas, 2004.

LIMONGI-FRANÇA, A. C. Comportamento Organizacional. São Paulo: Saraiva, 2005.

LIMONGI-FRANÇA, A. C. Práticas de recursos humanos PRH: conceitos, ferramentas e procedimentos. São Paulo: Atlas, 2007.

LITWIN, M. S., How to measure survey reliability and validity, Sage Publications, Inc, Survey Kit. 7, 1995.

LIU, W.; LEPAK, D. P.; TAKEUCHI, R.; SIMS JR, H. P. Matching leadership styles with employment modes: strategic human resource management perspective. Human Resource Management Review. 13 (2003) 127-152.

MAGALHÃES, M. N; LIMA, A. C. P. Noções de probabilidade e estatística. Revista Edusp. São Paulo, 2005.

MAQUIAVEL, N. O príncipe. Rio de Janeiro: Civilização Brasileira, 1976. 
MARRAS, J. P. Administração de recursos humanos: do operacional ao estratégico. São Paulo: Futura, 2000.

MAXIMIANO, A. C. A. Teoria geral da administração: da revolução urbana à revolução digital. São Paulo: Atlas, 2002.

MELEIRO, A. R. Bem-estar no trabalho: os aspectos do suporte do supervisor e estilos de liderança. Dissertação (Mestrado - Psicologia da Saúde) Universidade Metodista de São Paulo. São Bernardo do Campo, 2005.

MICHAELIS. Moderno Dicionário da Língua Portuguesa, 2007. Disponível em: <http://michaelis.uol.com.br/moderno/portugues/index.php>. Acesso em 02 set. 2007.

MILLS, C. W. A nova classe média - white collar. Rio de Janeiro: Zahar editores, 1979.

MINTZBERG, H. The manager's job: folklore and fact. Harvard business review, in special edition: the break through ideas: 2000.

MINTZBERG, H.; AHLSTRAND; LAMPEL. Safári de estratégia: um roteiro pela selva do planejamento estratégico. Porto Alegre: Bookman, 2000.

MONTANA, J. P.; CHARNOV, H. B. Administração. São Paulo: Saraiva, 1998.

MORIN, E. Os sentidos do trabalho. Revista de Administração de Empresas, São Paulo, v. 41, n. 3, p. 9-19, jul./set. 2001.

MORIN, E; TONELLI, M. J; PLIOPAS, A. L. V. O trabalho e seus sentidos. In.: ENCONTRO DA ASSOCIAÇÃO NACIONAL DOS PROGRAMAS DE PÓSGRADUAÇÃO EM ADMINISTRAÇÃO, 27., 2003, Atibaia. Anais... Atibaia: ENANPAD, 2003.

MUELLER, A.; MAYER, L. Liderança: novos conceitos diante de uma nova realidade. In: VI SEMEAD - Seminário de estudos em Administração - PPGA: FEA/USP; v. 1 (CD-Rom). São Paulo: 2003. (Anais... São Paulo: s.n., 2003).

MUNIZ, K. M.; DA SILVA, E. D. O papel do gerente na implementação da estratégia. Estratégias para o Desenvolvimento e Inserção Global. In: Congresso Latino-Americano de Estratégia, 18., 2004, Itapema. (Anais... Itapema: s.n., 2004).

NOGUEIRA, A. J. F. M. Gestão estratégica das relações de trabalho. In: FLEURY, M. T. L. (coord.). As pessoas na organização. 6. ed. São Paulo: Gente, 2002.

NOGUEIRA, A. J. F. M. Relações de trabalho e internacionalização no Brasil. In: FLEURY, A.; FLEURY, M. T. L. (Orgs.). Internacionalização e os países emergentes. São Paulo: Atlas, 2007.

NOGUEIRA, A. J. F. M. Teoria geral da administração para o século XXI. São Paulo: Ática, 2007.

OLIVEIRA, J. F. de. Profissão líder: desafios e perspectivas. Jayr Figueiredo de Oliveira (coord); Alberto Issao Sugo...(et al). São Paulo: Saraiva, 2007.

OLIVEIRA, S. R.; PICCININI, V. C.; D. S. FONTOURA; SCHWEIG, C. Buscando o Sentido do Trabalho. In: ENCONTRO DA ASSOCIAÇÃO NACIONAL DOS 
PROGRAMAS DE PÓS-GRADUAÇÃO EM ADMINISTRAÇÃO, 28., 2004, Curitiba. Anais... Curitiba: ENANPAD, 2004.

O. M. S - ORGANIZAÇÃO MUNDIAL DA SAÚDE. 2007. Disponível em: $<$ http://www.who.int/en/>. Acesso em 3 nov. 2007.

PFEFFER, J. Atributos \& símbolos. HSM Management, v. 55, mar./abr. 2006.

PICCOLO, R. F.; COLQUITT, J. A. Transformational Leadership And Job Behaviors: The Mediating Role Of Core Job Characteristics. Academy of Management Journal. 2006, vol. 49 , n. 2, 327-340.

POLO, E. F.; WEBER, W.; MAXIMO. M. D. C. Modelagens de liderança formal. In: ENANPAD, 2004, Curitiba PR. (Anais...Curitiba: s.n., 2004).

PORTER, M. Estratégia Competitiva: Técnicas para Análise de Industrias e da concorrência. Rio de Janeiro: Campos, 1986.

ProQuest powered by ProQuest ${ }^{\circledR}$ Smart Search. Dissertations \& Theses, ABI/INFORM Global. Disponível em: <http:// http://proquest.umi.com/pqdweb?TS=1194116191\&SST $=4 \&$ sid $=1 \&$ moreOptState $=$ CLOSED $\&$ SSM=C $\& S Q=L S U \% 28 \% 7 B L E A D E R S H I P \% 7 D \% 29$ $\&$ clientId=61611\&SSI=0\&RQT=305>. Acesso em 28 out. 2007.

ROBBINS, S. P. Comportamento organizacional. São Paulo: Prentice Hall, 2002.

ROBBINS, S. P. Administração. São Paulo. Saraiva, 2005.

RODRIGUES, M. V. C. Qualidade de vida no trabalho. 9. ed. Petrópolis: Vozes, 2002.

SANTOS, N. M. B. Clima Organizacional:_Pesquisa e Diagnóstico. São Paulo: Stiliano, 2000 .

SCHERMERHORN JR, J. Administração. Rio de Janeiro, 1996.

SCHEIN, E. H. Organizational culture and leadership. Jossey-Bass Publishers. São Francisco, 1992.

SENNET, R. A corrosão do caráter: as conseqüências pessoais do trabalho no novo capitalismo. $4^{\mathrm{a}}$ ed. Rio de Janeiro: Record, 2000.

SILVA, R. O. Teorias da Administração. São Paulo: Pioneira Thomson Learning, 2002.

SOTO, E. Comportamento Organizacional. São Paulo, Pioneira Thomson Learning, 2002.

STEFANO, S. R.; GOMES FILHO, A. C. Estilos de Liderança: um estudo comparativo entre empresas de transporte. In: ENANPAD, 2003, Atibaia SP. (Anais... Atibaia: s.n., 2003).

STEFANO, S. R.; GOMES FILHO, A. C. Estilos de liderança: um estudo comparativo entre empresas de transportes. Revista Capital Científico. Guarapuava, v. 2, n. 1, jan./dez. 2004a.

STEFANO, S. R.; GOMES FILHO, A. C. O Desemprego e a Empregabilidade: um estudo multi casos In: ENCONTRO DA ASSOCIAÇÃO NACIONAL DOS PROGRAMAS DE PÓS-GRADUAÇÃO EM ADMINISTRAÇÃO, 28., 2004, Curitiba. Anais... Curitiba: ENANPAD, 2004b. 
STEFANO, S. R.; NOGUEIRA, A. M. Tendências Do Trabalho Atípico No Brasil. In: ENCONTRO DA ASSOCIAÇÃO NACIONAL DOS PROGRAMAS DE PÓSGRADUAÇÃO EM ADMINISTRAÇÃO, 30, Salvador, 2006. Anais... Salvador: Associação Nacional dos Programas de Pós-Graduação em Administração, 2006. 1 CD-ROM.

STONER, J. A.; FREEMAN, R. E. Administração. Rio de Janeiro: LTC, 1999.

TANURE, B.; DUARTE, R. G. O impacto da diversidade cultural na gestão internacional. In: TANURE, B.; DUARTE, R. G. (Orgs.). Gestão internacional. São Paulo: Saraiva, 2006.

THE R PROJECT FOR STATISTICAL COMPUTING (2008). http://www.r-project.org/. Acesso em 25 ago. 2008.

ULRICH, D. Os campeões de recursos humanos: inovando para obter os melhores resultados. São Paulo: Futura, 1998.

ULRICH, D. Results-Basead Leadership. Boston: Havard Business Scholl Press, 1999.

ULRICH, D.; ZENGER, J.; SMALLWOOD, N. Liderança orientada para resultados. São Paulo: Campus, 2000.

UlRICH, D.; WAYNE, B. The H. R. Value Proposition. Harvard Business School Press. Boston, 2005.

VASAPOLLO, L. O trabalho atípico e a precariedade. São Paulo: Expressão Popular, 2005.

VENDRAMINI, P. Liderança e mudança organizacional: as categorias essenciais do líder facilitador. Programa de Pós-Graduação da Engenharia de Produção e Sistemas (Dissertação de Mestrado). Universidade Federal de Santa Catarina, Florianópolis: 2000.

VERGARA, S. C. Gestão de Pessoas. São Paulo, Atlas, 2000.

VERGARA, S. C. Projetos e relatórios de pesquisa em administração. São Paulo: Atlas, 2005 .

WAGNER III, J. A.; HOLLENBECK, J. Comportamento organizacional: criando vantagem competitiva. São Paulo: Ed. Saraiva, 1999.

WEBER, M. Ciência e política: duas vocações. São Paulo: Cultrix, 1970.

WOOD JR., T. (coord). Mudança organizacional: aprofundando temas atuais em administração de empresas. São Paulo: Atlas, 2000.

WRIGHT, P.; KROLL, M.; PARNELL, L. Administração estratégica: conceitos. São Paulo: Atlas, 2000.

YIN, R. K. Estudo de caso: planejamento e métodos. Porto Alegre: Bookman, 2005.

ZALEZNIK, A. Gerentes ou líderes: qual a diferença? Harvard Business Review, Janeiro, 2004, p.60-67. 
APÊNDICES

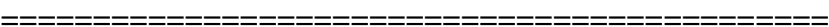


$\underline{6}$

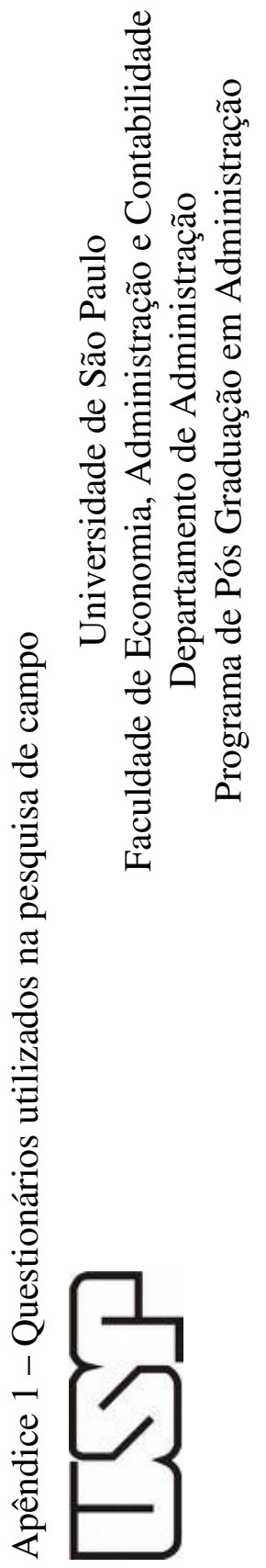

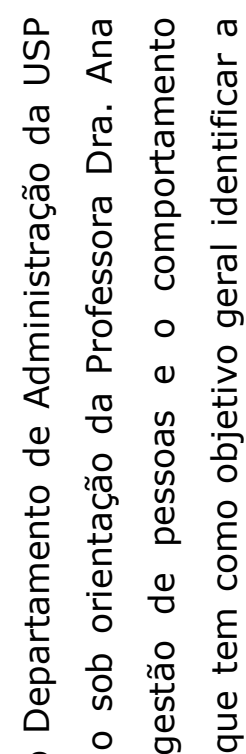

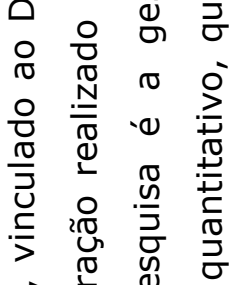

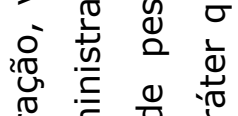

苞

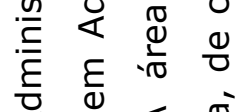

\&

๕

芯

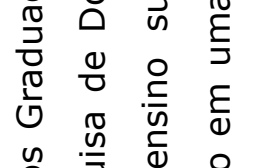

资

ป ญ 巳

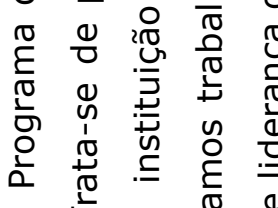

음

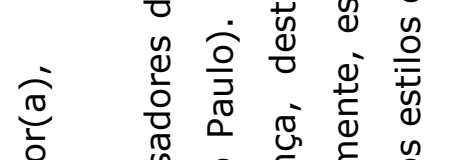

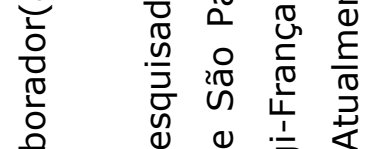

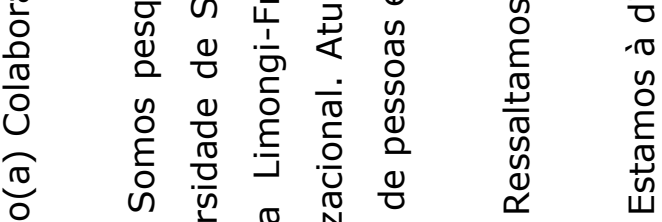

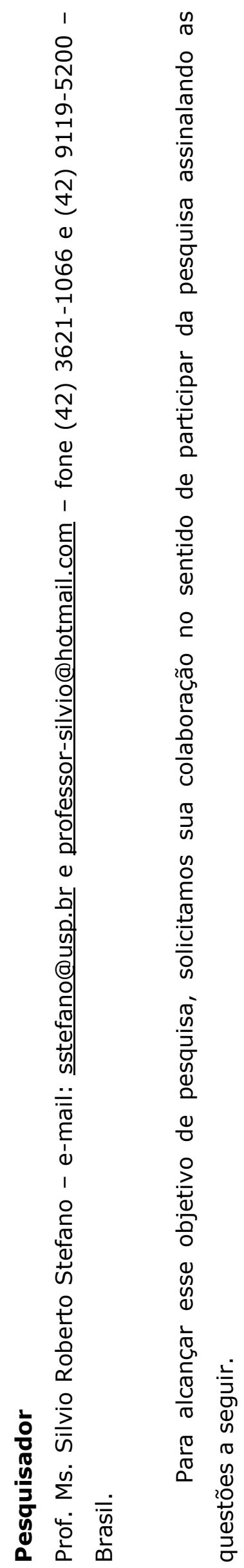


$\stackrel{\circ}{\circ}$

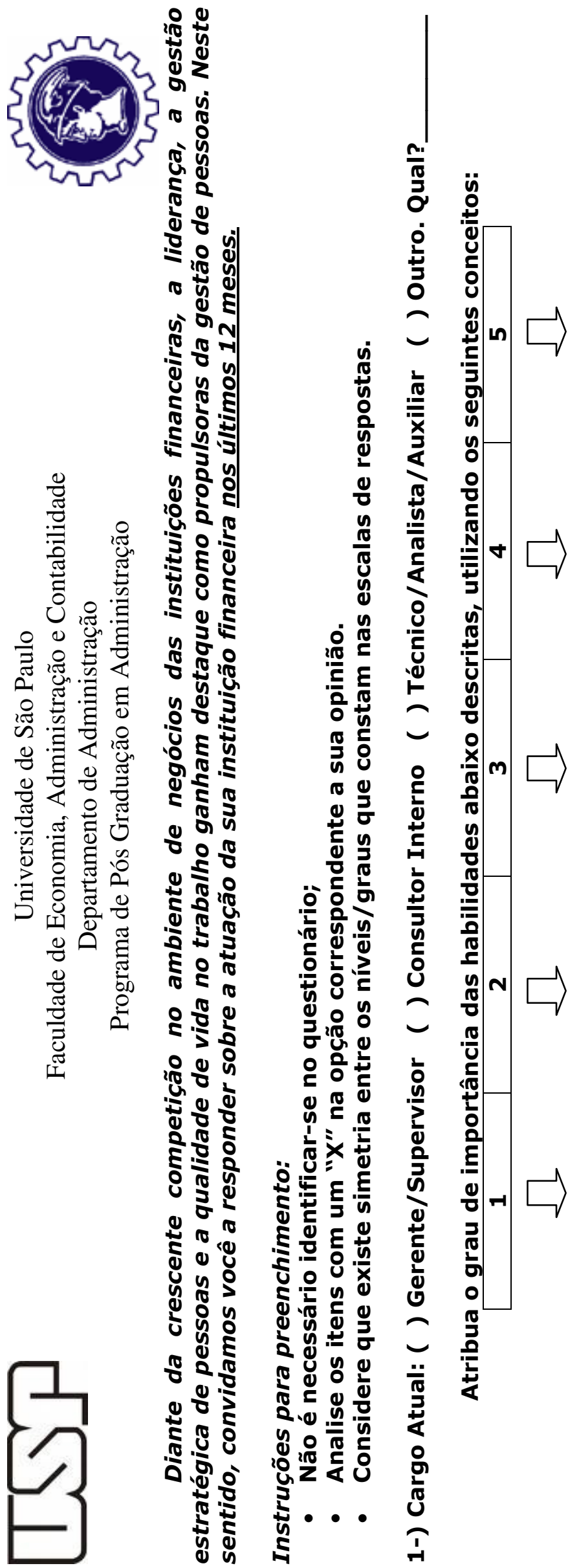

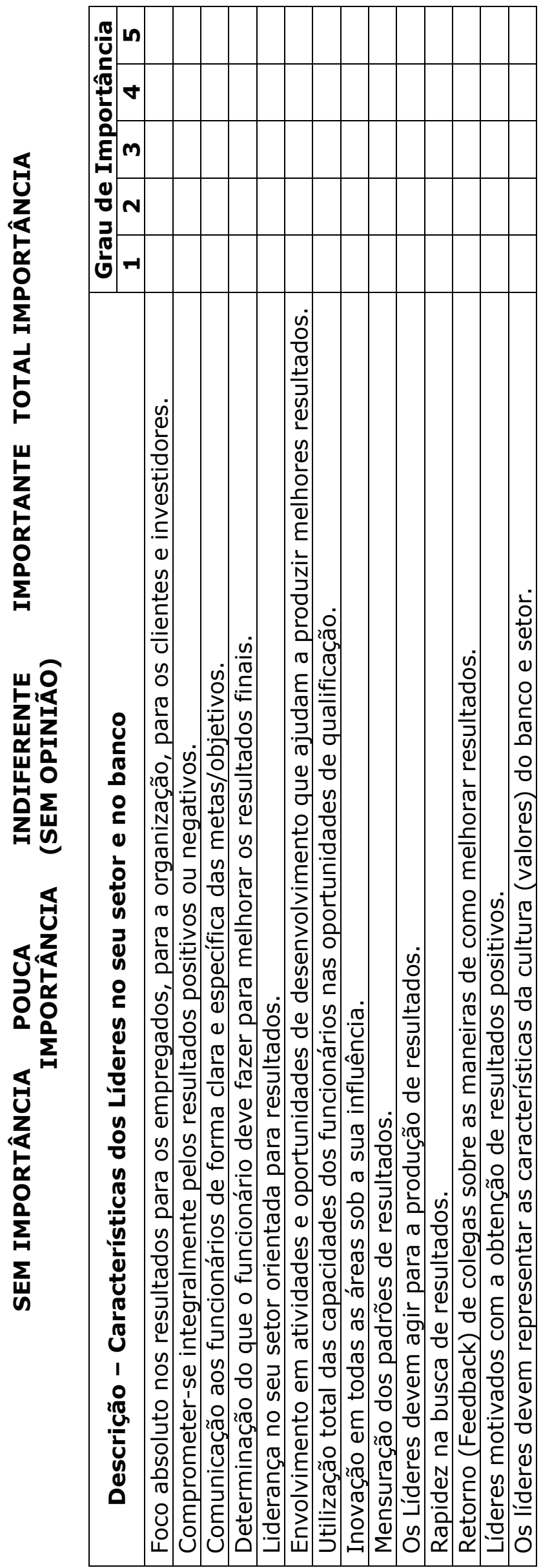


$\underline{6}$
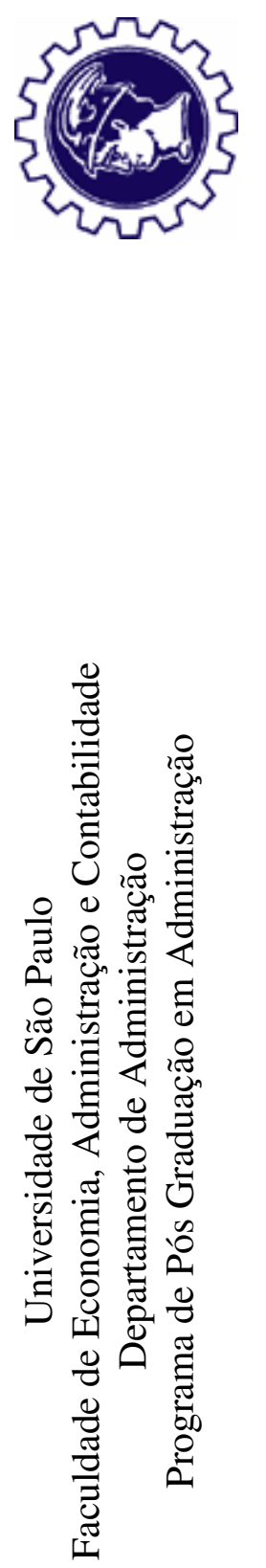

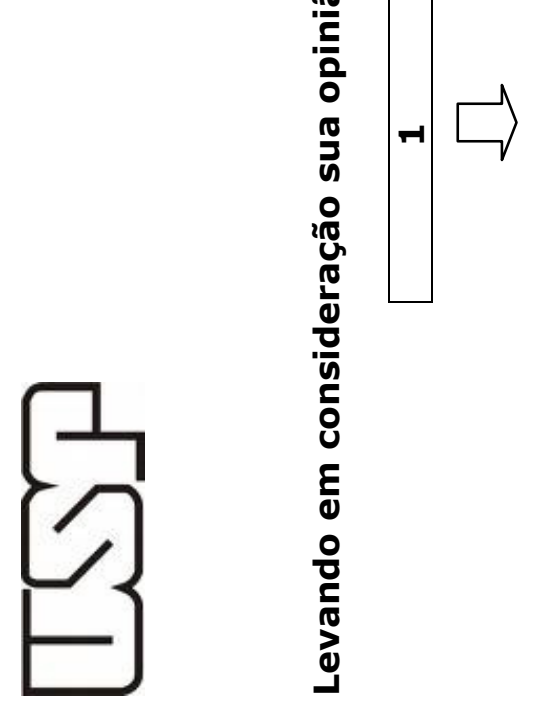

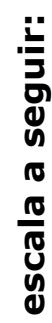

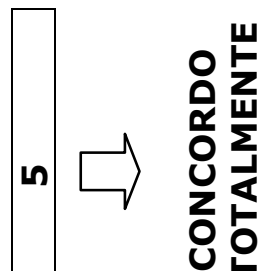

\section{ธ}

س

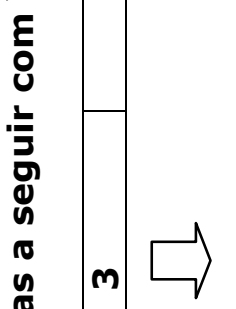

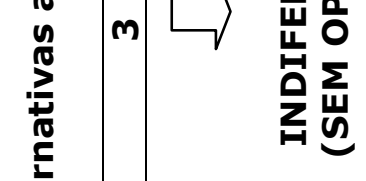

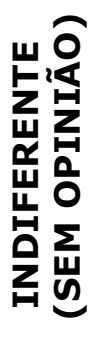

을

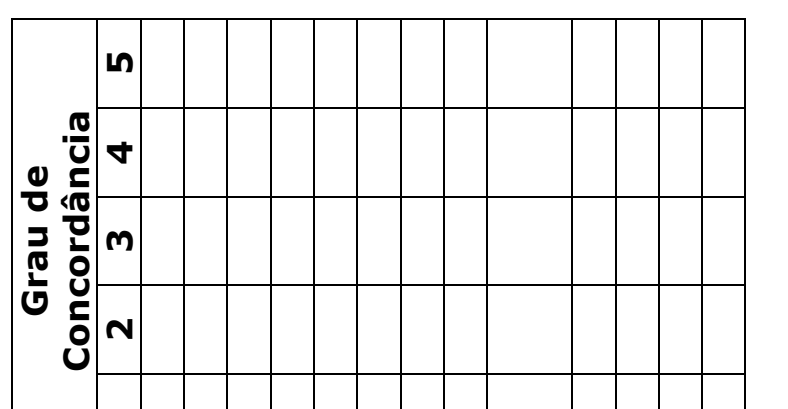

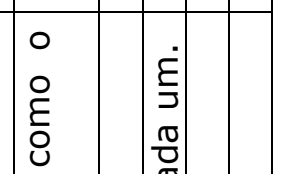

일

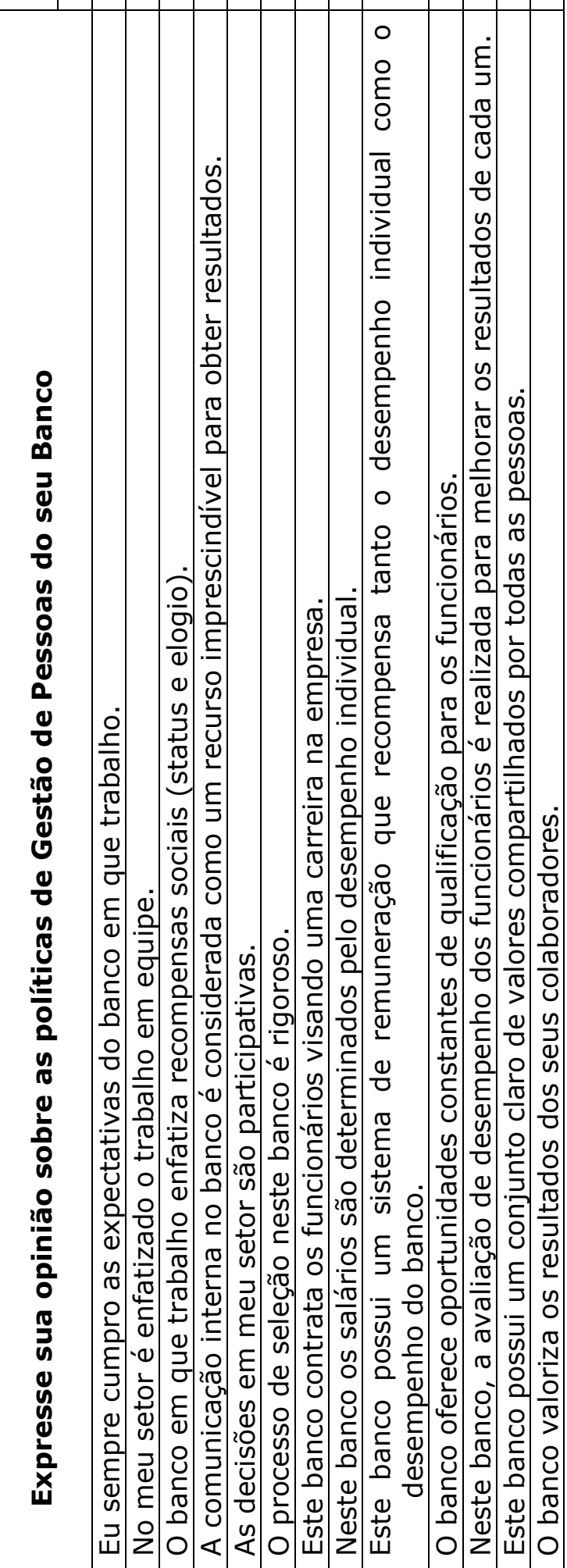




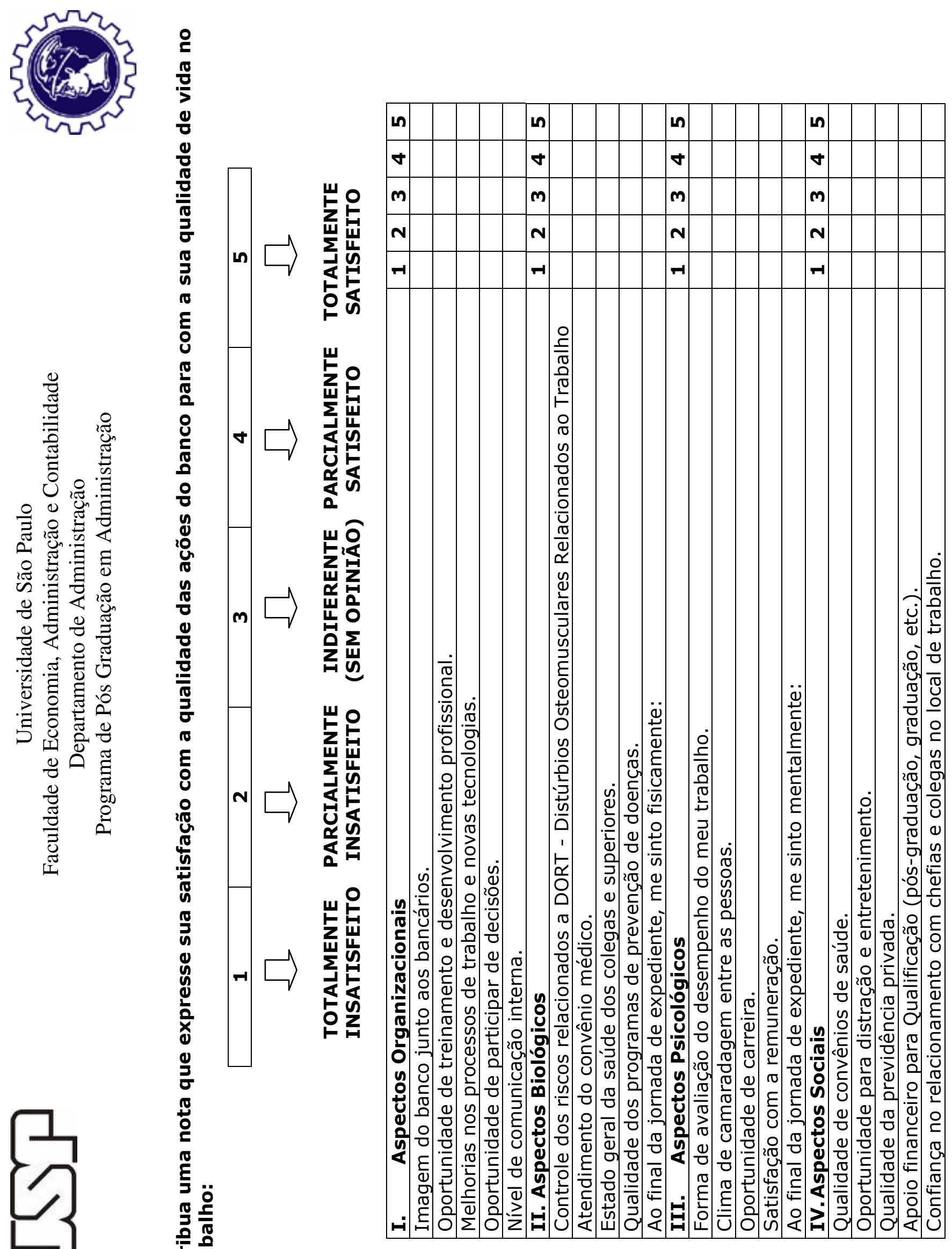



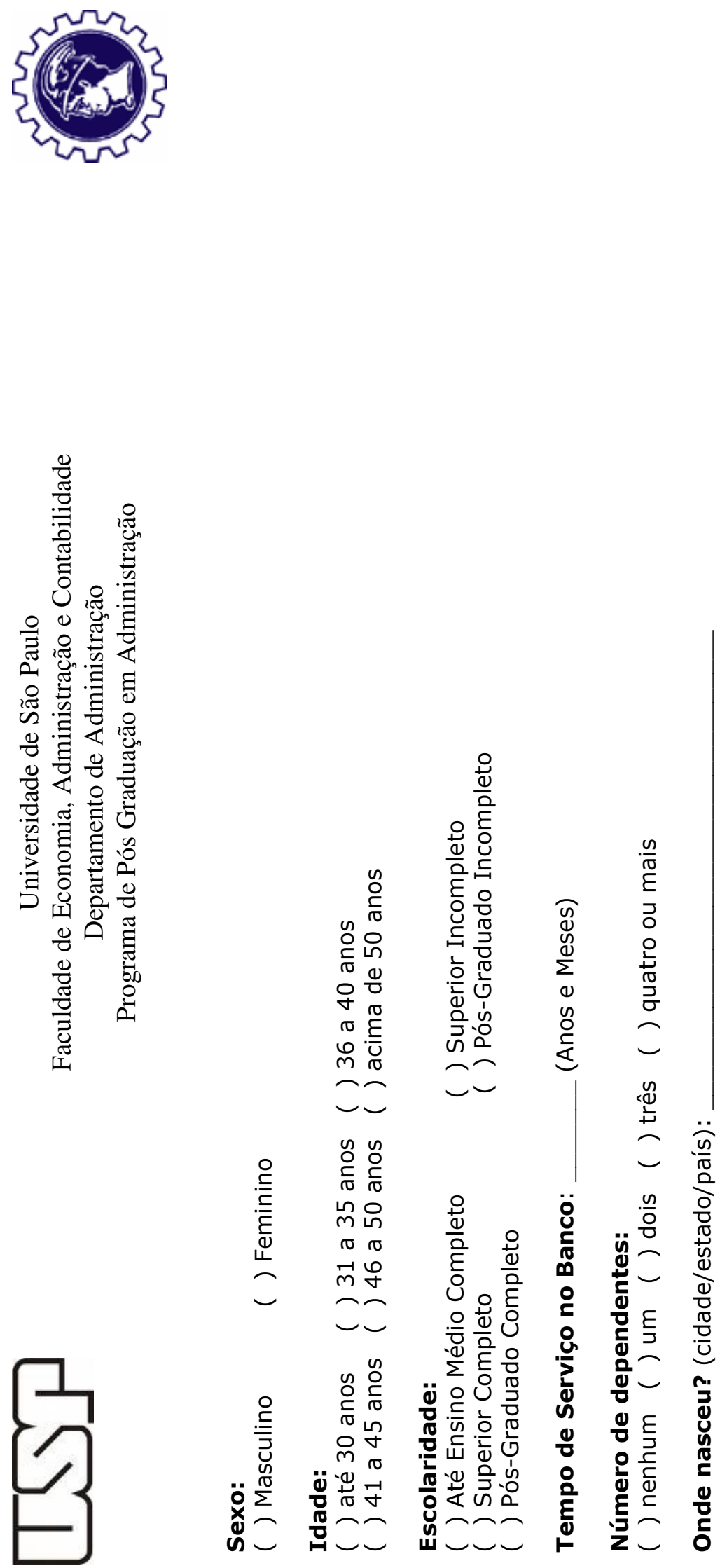
Apêndice 2 - Roteiro de Entrevista utilizados na pesquisa de campo

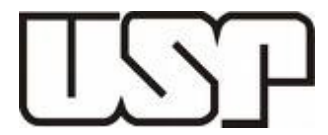

Universidade de São Paulo

Faculdade de Economia, Administração e Contabilidade

Departamento de Administração

Programa de Pós Graduação em Administração

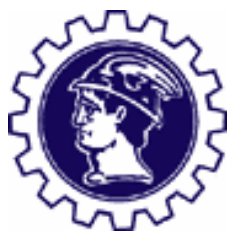

Prezado(a) Colaborador(a),

Somos pesquisadores do Programa de Pós Graduação em Administração, vinculado ao Departamento de Administração da USP (Universidade de São Paulo). Trata-se de pesquisa de Doutorado em Administração realizado sob orientação da Professora Dra. Ana Cristina LimongiFrança, desta instituição de ensino superior. A área de pesquisa é a gestão de pessoas e o comportamento organizacional. Atualmente, estamos trabalhando em uma pesquisa, de caráter qualitativo e quantitativo, que tem como objetivo geral identificar a gestão de pessoas e os estilos de liderança dos bancários.

Ressaltamos que todas as informações coletadas durante a pesquisa serão mantidas sob estrito sigilo.

Estamos à disposição para esclarecer qualquer dúvida referente à pesquisa. No aguardo do retorno,

\section{Pesquisador}

Prof. Ms. Silvio Roberto Stefano - e-mail: sstefano@usp.br e professor-silvio@ hotmail.com - fone (42) 3621-1066 e (42) 9119-5200 - Brasil.

Para alcançar esse objetivo de pesquisa, solicitamos sua colaboração no sentido de participar da pesquisa.

Diante da crescente competição no ambiente de negócios das instituições financeiras, a liderança, a gestão estratégica de pessoas e a qualidade de vida no trabalho ganham destaque como propulsoras da gestão de pessoas. Neste sentido, convidamos você a responder sobre a atuação da sua instituição financeira nos últimos 12 meses.

\section{Instruções:}

a) Responda as questões considerando a percepção individual (para você)

b) Responde as questões considerando o que você percebe na sua Instituição Financeira (para o conjunto de funcionários) 
1-) Como é o envolvimento em atividades e oportunidades de desenvolvimento? Ajudam a produzir melhores resultados?

a)

b)

2-) Como é o conhecimento e utilização das capacidades dos funcionários nas oportunidades de desenvolvimento (qualificação)?

a)

b)

3-) Como é a inovação nas áreas sob a sua influência? busca novas maneiras de melhorar o desempenho?

a)

b)

4-) Como é o retorno (Feedback) de colegas sobre como melhorar resultados?

a)

b)

\section{Gestão de Pessoas:}

1) O sistema de recompensas e punições é?

a)

b)

2) O processo de seleção neste banco é?

a)

b)

3) Neste banco os salários são determinados pelo seu desempenho individual?

a)

b)

4) O banco oferece oportunidades constantes de qualificação para os funcionários? Como?

a)

b)

\section{Qualidade das ações da sua instituição financeira}

\section{Aspectos Organizacionais}

1. Como são as oportunidades de treinamento e desenvolvimento profissional?

a)

b)

2. Como são as oportunidades de participar de decisões?

a)

b) 
3. Nível de comunicação interna é?

a)

b)

\section{Aspectos Biológicos}

1. Como são os controles dos riscos ergonômicos DORT - Distúrbios Osteomusculares Relacionados ao Trabalho?

a)

b)

2. Ao final da jornada de expediente, você se sente fisicamente?

a)

b)

\section{Aspectos psicológicos}

1. Como são as oportunidades de carreira?

a)

b)

2. Como é a Satisfação com a remuneração?

a)

b)

3. Ao final da jornada de expediente, você se sente mentalmente?

a)

b)

\section{Aspectos Sociais}

1. Como é a qualidade dos seguros de previdência privada?

a)

b)

2. Como são os apoios financeiros para qualificação?

a)

b) 
RECRUTAMENTO E SELEÇÃO:

TREINAMENTO E DESENVOLVIMENTO:

CARGOS E SALÁRIOS:

BENEFÍCIOS SOCIAIS:

AVALIAÇÃO DE DESEMPENHO:

HIGIENE E SEGURANÇA NO TRABALHO: 


\section{Apêndice 3 - Ficha de Documentação da Entrevista}

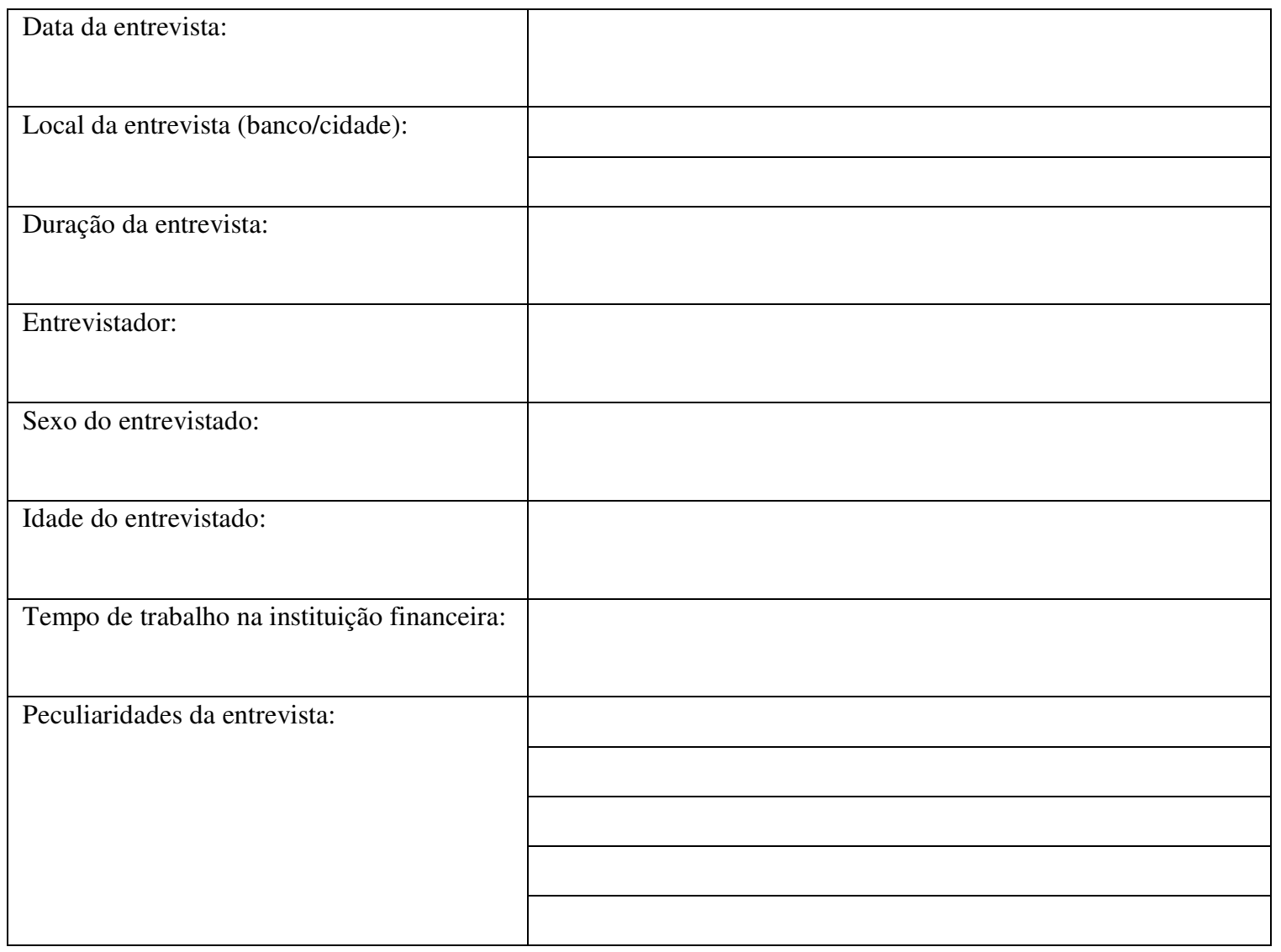

Fonte: Flick (2005). Transcrição parcial. 
Apêndice 4 - Comunalidades por Questões

\begin{tabular}{|c|c|}
\hline Q2 & 0,41 \\
\hline Q3 & 0,359 \\
\hline $\mathrm{Q} 4$ & 0,389 \\
\hline Q5 & 0,362 \\
\hline Q6 & 0,484 \\
\hline Q7 & 0,271 \\
\hline Q8 & 0,321 \\
\hline Q9 & 0,463 \\
\hline Q10 & 0,472 \\
\hline Q11 & 0,466 \\
\hline Q12 & 0,59 \\
\hline Q13 & 0,403 \\
\hline Q14 & 0,351 \\
\hline Q15 & 0,292 \\
\hline Q16 & 0,507 \\
\hline Q17 & 0,523 \\
\hline Q18 & 0,506 \\
\hline Q19 & 0,524 \\
\hline Q20 & 0,467 \\
\hline Q21 & 0,447 \\
\hline Q22 & 0,395 \\
\hline Q23 & 0,484 \\
\hline Q24 & 0,386 \\
\hline Q25 & 0,329 \\
\hline Q26 & 0,395 \\
\hline Q27 & 0,539 \\
\hline Q28 & 0,248 \\
\hline Q29 & 0,557 \\
\hline Q30 & 0,395 \\
\hline Q31 & 0,553 \\
\hline Q32 & 0,356 \\
\hline Q33 & 0,553 \\
\hline Q34 & 0,447 \\
\hline Q35 & 0,333 \\
\hline Q36 & 0,536 \\
\hline Q37 & 0,601 \\
\hline Q38 & 0,41 \\
\hline Q39 & 0,487 \\
\hline Q40 & 0,314 \\
\hline Q41 & 0,265 \\
\hline Q42 & 0,453 \\
\hline Q43 & 0,005 \\
\hline Q44 & 0,329 \\
\hline Q45 & 0,551 \\
\hline Q46 & 0,66 \\
\hline Q47 & 0,515 \\
\hline Q48 & 0,356 \\
\hline
\end{tabular}

Fonte: Dados da pesquisa 
Apêndice 5 - Teste Qui-Quadrado de Associação

\begin{tabular}{|c|c|c|}
\hline \multirow{2}{*}{ Instituição } & \multicolumn{2}{|c|}{ Liderança } \\
\hline & Baixa & Alta \\
\hline Alfa & 6 & 57 \\
\hline Beta & 41 & 52 \\
\hline \multirow{2}{*}{ Instituição } & \multicolumn{2}{|c|}{ Gestão de Pessoas } \\
\hline & Baixa & Alta \\
\hline Alfa & 22 & 41 \\
\hline Beta & 73 & 20 \\
\hline \multirow{2}{*}{ Instituição } & \multicolumn{2}{|c|}{ Aspectos Organizacionais } \\
\hline & Baixa & Alta \\
\hline Alfa & 21 & 42 \\
\hline Beta & 66 & 27 \\
\hline \multirow{2}{*}{ Instituição } & \multicolumn{2}{|c|}{ Aspectos Biológicos } \\
\hline & Baixa & Alta \\
\hline Alfa & 8 & 55 \\
\hline Beta & 41 & 52 \\
\hline \multirow{2}{*}{ Instituição } & \multicolumn{2}{|c|}{ Aspectos Psicológicos } \\
\hline & Baixa & Alta \\
\hline Alfa & 19 & 44 \\
\hline Beta & 57 & 36 \\
\hline \multirow{2}{*}{ Instituição } & \multicolumn{2}{|c|}{ Aspectos Sociais } \\
\hline & Baixa & Alta \\
\hline Alfa & 26 & 37 \\
\hline Beta & 69 & 24 \\
\hline
\end{tabular}

\begin{tabular}{|c|c|c|}
\hline \multirow{2}{*}{ Instituição } & \multicolumn{2}{|c|}{ Liderança } \\
\hline & Baixa & Alta \\
\hline Alfa & $10 \%$ & $90 \%$ \\
\hline Beta & $44 \%$ & $56 \%$ \\
\hline \multirow{2}{*}{ Instituição } & \multicolumn{2}{|c|}{ Gestão de Pessoas } \\
\hline & Baixa & Alta \\
\hline Alfa & $35 \%$ & $65 \%$ \\
\hline Beta & $78 \%$ & $22 \%$ \\
\hline \multirow{2}{*}{ Instituição } & \multicolumn{2}{|c|}{ Aspectos Organizacionais } \\
\hline & Baixa & Alta \\
\hline Alfa & $33 \%$ & $67 \%$ \\
\hline Beta & $71 \%$ & $29 \%$ \\
\hline \multirow{2}{*}{ Instituição } & \multicolumn{2}{|c|}{ Aspectos Biológicos } \\
\hline & Baixa & Alta \\
\hline Alfa & $13 \%$ & $87 \%$ \\
\hline Beta & $44 \%$ & $56 \%$ \\
\hline \multirow{2}{*}{ Instituição } & \multicolumn{2}{|c|}{ Aspectos Psicológicos } \\
\hline & Baixa & Alta \\
\hline Alfa & $30 \%$ & $70 \%$ \\
\hline Beta & $61 \%$ & $39 \%$ \\
\hline \multirow{2}{*}{ Instituição } & \multicolumn{2}{|c|}{ Aspectos Sociais } \\
\hline & Baixa & Alta \\
\hline Alfa & $41 \%$ & $59 \%$ \\
\hline Beta & $74 \%$ & $26 \%$ \\
\hline
\end{tabular}

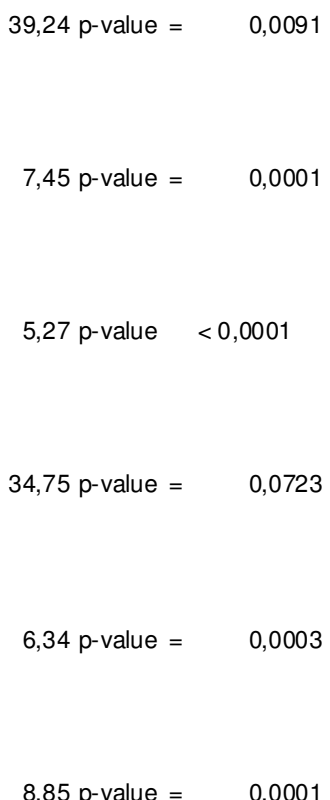

$8,85 p$-value $=\quad 0,0001$ 